\title{
RAEMAEKERS CARTOONS
}

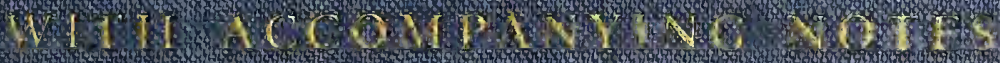

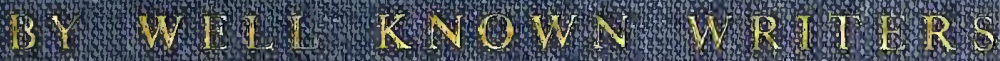




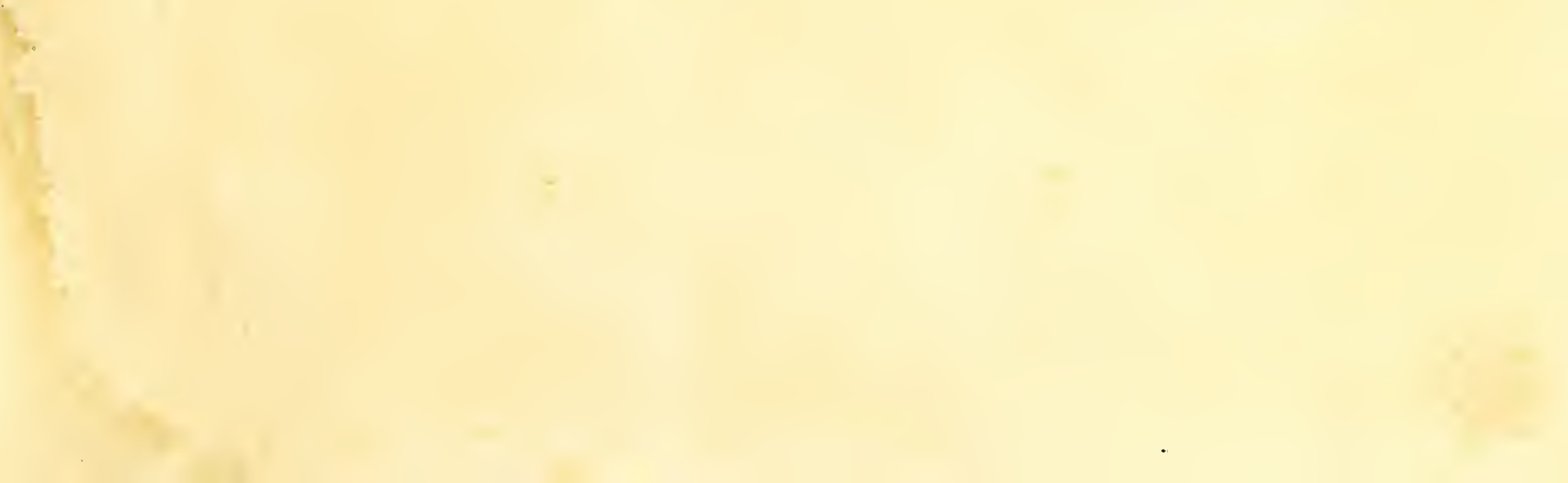




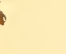


RAEMAEKERS' CARTOONS 


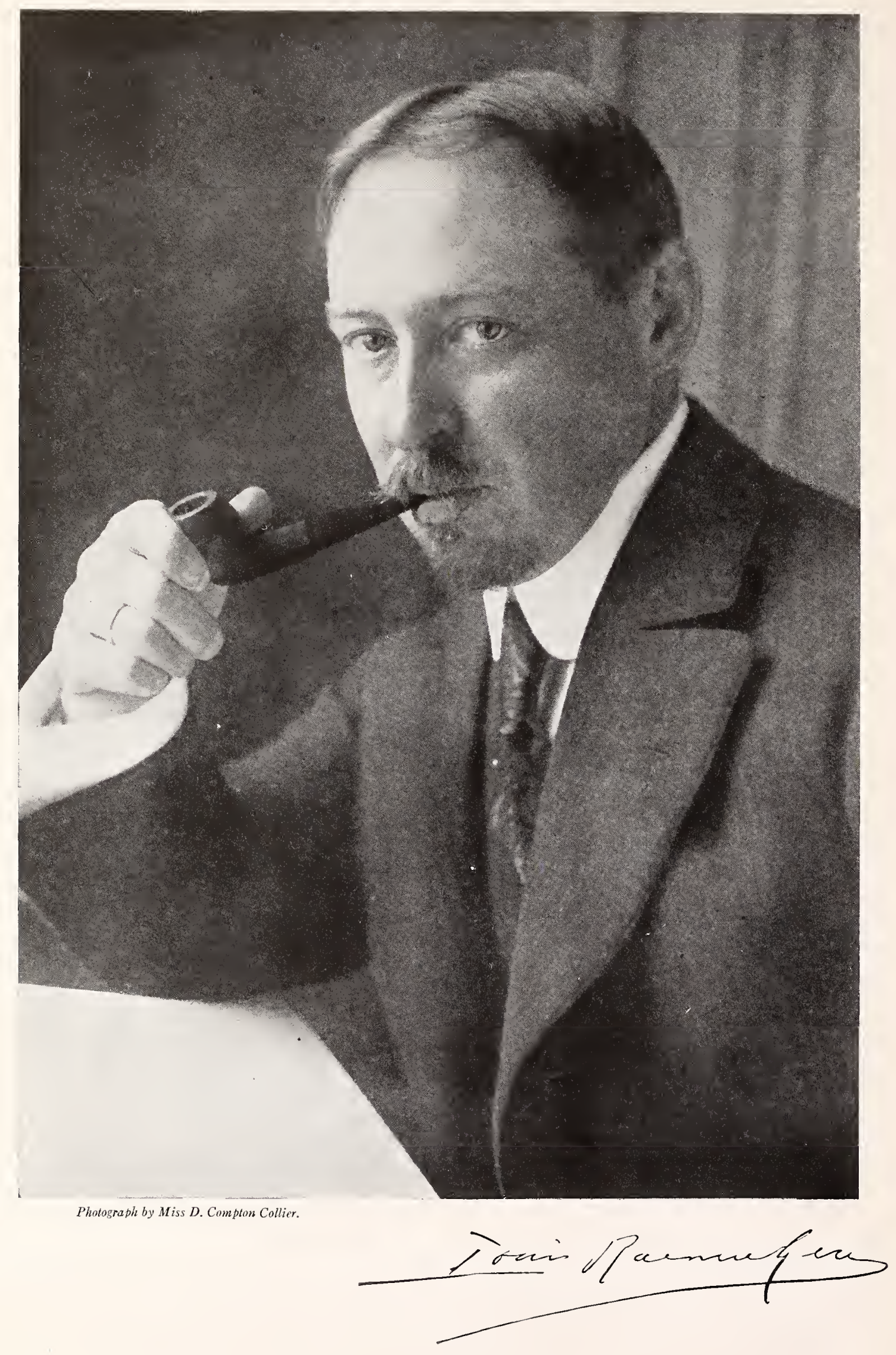




\section{RAEMAEKERS CARTOONS}

WITH ACCOMPANYING NOTES BY
WELL-KNOWN ENGLISH WRITERS

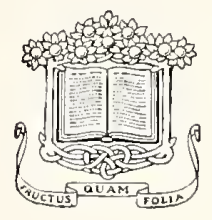

WITH AN APPRECIATION FROM H. H. ASQUITH, PRIME MINISTER OF ENGLAND 
Copyright, 1916, by Doubleday, Page \& Company All rights reserved, including that of translation into foreign languages, including the Scandinavian 


\section{List of Cartoons and the Descriptive Notes}

\begin{tabular}{|c|c|c|c|c|c|c|c|c|}
\hline \multirow{2}{*}{\multicolumn{9}{|c|}{ PORTRAIT OF Louis RaEmaEkERS - }} \\
\hline INTRODUCTION & & & - & - & - & - & - Francis Stopford & \\
\hline AN APPRECIATION & FROM & THE & PRIM & IE MiN & NISTER & $R$ - & - H.H. Asquith & \\
\hline CHRISTENdOM AFTI & ER Th & WEN' & Y CEI & INTURII & & - & - Francis Stopford & 8 \\
\hline A Stable PEace & - & - & - & - & - & - & - Eden Phillpotts & 10 \\
\hline The Massacre of & THE & INNO & CENT: & S - & - & - & - E. Charles Vivian & 12 \\
\hline BERNHARDIISM & & - & - & - & - & - & - Hilaire Belloc & 14 \\
\hline FroM LIÈGE TO AI & IX-LA- & -СНА & PELLE & $\mathrm{E}-$ & - & - & - Francis Stopford & 16 \\
\hline SPOILS FOR THE VI & ICTORS & & - & - & - & - & - Hilaire Belloc & 18 \\
\hline The Very Stones & CRY & Out & - & - & - & - & - Bernard Vaughan, S.J. & 20 \\
\hline SATAN'S PARTNER & & - & - & - & - & - & - G.K.Chesterton & 22 \\
\hline THROWN TO THE S & WINE & _ & _ & - & _ & - & - The Dean of St. Paul's & 24 \\
\hline The LAND Mine & - & - & - & - & - & - & - Herbert Warren & 26 \\
\hline “For Your MoTH & IERLAN & ND" & - & - & - & - & - Eden Phillpotts & 28 \\
\hline The German Loal & & - & - & - & - & - & - E. Charles Vivian & 30 \\
\hline Europe, 1916 & 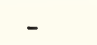 & - & - & - & - & - & - G.K. Chesterton & 32 \\
\hline 'THE Next to Be & KICKE & $\mathrm{EDO}$ & $\mathrm{UT}-\mathrm{T}$ & רי & & ASTER & - Arthur Pollen & 34 \\
\hline The Friendly VIs & SITOR & - & - & - & - & - & - H. DeVere Stacpoole & 36 \\
\hline "To Your Healti & $\mathrm{H}$, CIV & VILIZ & ATION & & - & - & - The Dean of s't. Paul's & 38 \\
\hline Fox TIRPITZ PREA & ICHING & $\mathrm{TO}$ & THE G & GeEse & - & - & - Herbert Warren & 40 \\
\hline The Prisoners & - & - & - & - & - & - & - Eden Phillpotts & 42 \\
\hline IT'S UNBELIEVABLI & & - & - & - & - & - & - Hilaire Belloc & 44 \\
\hline KreuZland, Kreu & UZLAND & & & LLES & - & - & - The Dean of St.Paul's & 46 \\
\hline ThE EX-CONVICT & - & - & - & - & - & - & - Hilaire Belloc & 48 \\
\hline Miss CAVELL - & - & - & - & - & - & - & - G.K. Chesterton & 50 \\
\hline The Hostages & - & - & - & - & - & - & - John Oxenham & 52 \\
\hline KING ALBERT's AN & NSWE & To & THE $\mathrm{P}$ & POPE & - & - & - E. Charles Vivian & 54 \\
\hline THE GAS FiEnd & & - & - & - & - & - & - Eden Phillpotts & 56 \\
\hline The German Tan & & . & - & - & - & - & - John Buchan & 58 \\
\hline The ZePpelin Tri & IUMPH & & - & - & - & - & - W. L. Courtney & 60 \\
\hline KeEPING OUT THE & ENEM & & - & - & - & - & - H.DeVere Stacpoole & 62 \\
\hline The German OfFI & & - & - & - & - & - & - Hilaire Belloc & 64 \\
\hline The Wolf Trap & & - & - & - & - & - & - Herbert Warren & 66 \\
\hline Ahasuerus II & & - & - & - & 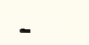 & . & - John Buchan & 68 \\
\hline OUR CANDID FRIEI & & - & - & - & - & - & - The Dean of St. Paul's & 70 \\
\hline
\end{tabular}




\section{LIST OF CARTOONS AND THE DESCRIPTIVE NOTES}

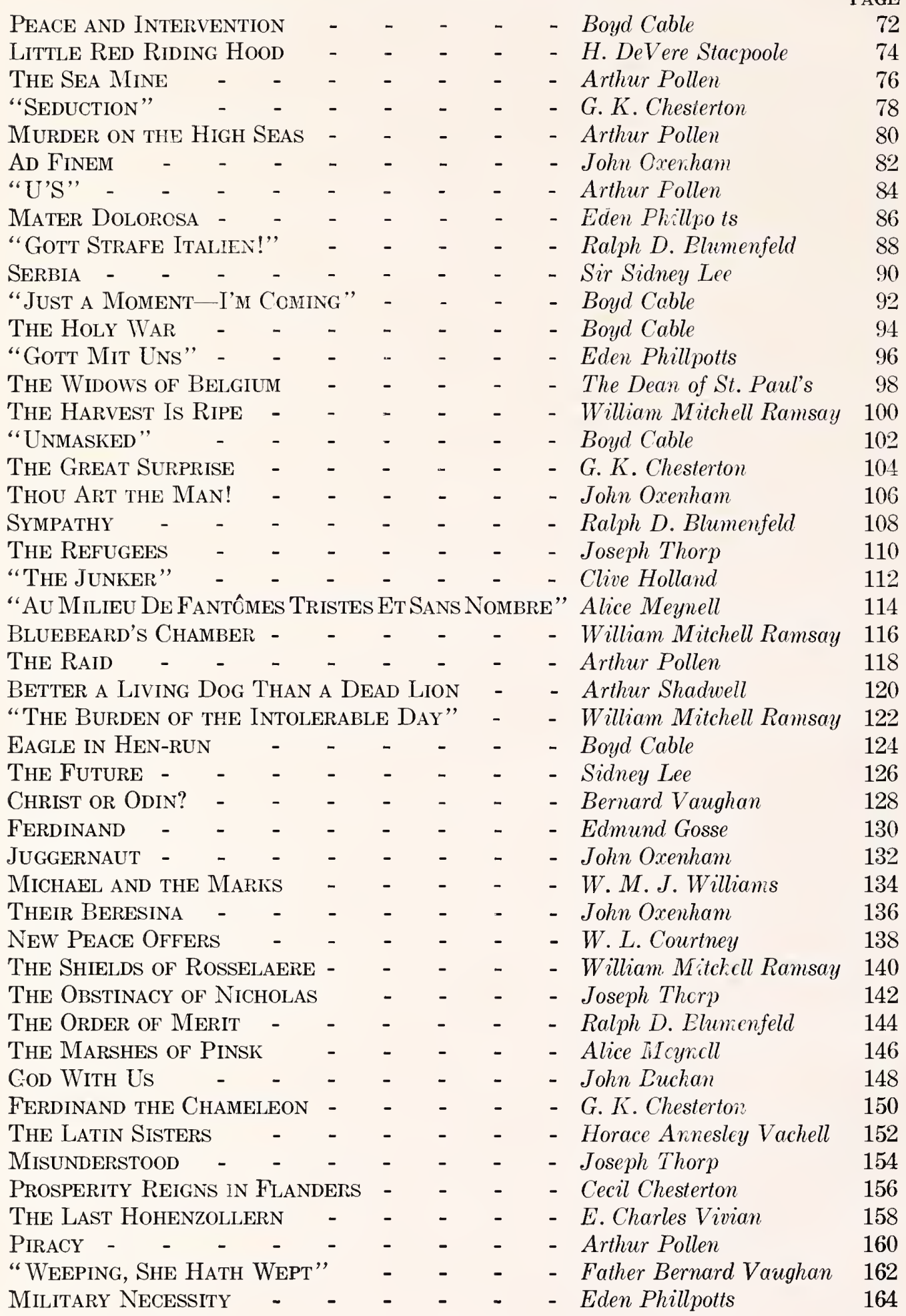




\section{LIST OF CARTOONS AND THE DESCRIPTIVE NOTES}

Liberté! LIBERTÉ, CHÉRIE!

I- "A KNAVISH PIECE OF WoRK" -

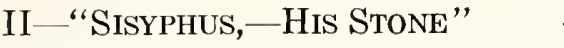

CONCRETE Foundations

Pallas Athene

The Wonders of Culture - - -

"Folk Who Do Not Understand Them"

ON THE WaY to CALAIS - - - - -

Von Bethmann-Hollweg and TRUTH -

VAN Tromp and De RUYTer - - -

WAR AND CHRIST - $\quad$ - $\quad$ - $\quad$ -

BARBED Wire $\quad-\quad-\quad-\quad-\quad-$

The Higher Politics - - - - -

The LoAn Game - $\quad-\quad-\quad-\quad-$

4 WAR OF RAPINE - $\quad-\quad-\quad-\quad-$

The Dutch Junkers $\quad-\quad-\quad-$

The War Makers - $\quad$ - $\quad$ -

The Christmas of Kultur, A.D. 1915 -

SERBIA - $\quad$ - $\quad$ - $\quad-\quad-\quad-\quad-$

The Last OF THE RACE - $\quad-\quad-\quad-$

The Curriculum - $\quad-\quad-\quad-\quad-$

The Dutch Journalist to His Belgian Confrère

A Boped CRITIC -

"The Peace Woman" -

The Self-Satisfied Burgher $\quad-\quad-\quad-$

The Decadent

LIQUID FIRE - $\quad-\quad-\quad-\quad-\quad-\quad-$

NISH AND PARIS $-\quad-\quad-\quad-\quad-\quad-$

GotT STRAFE England! - - - - - -

The Pacificist Kaiser (The Confederates)

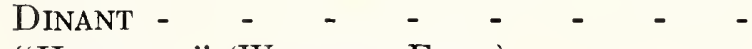

"HeSPERIA" (WOUNDED First) - - -

GALlIPOLI - $\quad$ - $\quad$ - $\quad$ - $\quad$ - $\quad$ -

The Beginning of the Expiation - -

The ShIRKERS - $\quad-\quad-\quad-\quad-\quad-$

ONe of the Kaiser's Many Mistakes - -

BELgIUM IN HollaNd - $\quad-\quad-\quad-\quad-$

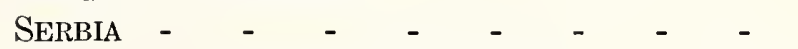

JACKALS IN THe Political Field - - - -

His Master's Voice - $\quad-\quad-$

HuN GENEROSITY - $\quad-\quad$ - $\quad-\quad$ -

EASTER, $1915 \quad-\quad$ - $\quad$ - $\quad$ -

Pan Germanicus as Peace Maker - -

Gott Mit UNS - $\quad$ - $\quad$ - $\quad$ - $\quad$ -

OUR LADY OF ANTWERP - $-\quad-\quad-\quad-$

DePORTATION - $\quad-\quad-\quad-\quad-\quad-$
- John Oxenham $\quad$ i66

- George Birdwood 168

- George Birdwood 170

- A. Shadwell 172

- Herbert Warner 174

- Clive Holland 176

- Bernard Vaughan $\quad 178$

- Eden Phillpotts 180

- Herbert Warren 182

- Arthur Pollen 184

- Cecil Chesterton 186

- E. Charles Vivian 188

- Boyd Cable 190

- W.M.J.Williams 192

- E. Charles Vivian 194

- A. Shadwell 196

- John Oxenham 198

- A. Shadwell 200

- Horace Annesley Vachell 202

- Arthur Pollen 204

W. M. J. Williams 206

G. K. Chesterton 208

- Eden Phillpotts 210

- Clive Holland 212

- W. L. Courtney 214

- John Oxenham 216

- Clive Holland 218

- Sidney Lee 220

- Cecil Chesterton 222

- Sidney Lee 224

- W.R. Inge 226

- H. DeVere Stacpoole 228

- G.K. Chesterton 230

- G. K. Chesterton 232

- Sidney Lee 234

- John Oxenham 236

- Edmund Gosse 238

- William Mitchell Ramsay 240

- Herbert Warren 242

- Cecil Chesterton 244

- A. Shadwell 246

- Horace Annesley Vachell 248

- G.K.Chesterton 250

- Alfred Stead 252

- Cecil Chesterion 254

- W. L. Courtney 256

- Cecil Chesterton 258 


\section{LIST OF CARTOONS AND THE DESCRIPTIVE NOTES}

\begin{tabular}{|c|c|c|c|c|c|c|}
\hline & & & & & & 60 \\
\hline $\begin{array}{l}\text { THE GERMAN BAND } \\
\text { ARCADES AMBO }\end{array}$ & 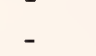 & - & - & - & $\begin{array}{l}\text { - John Uxennam } \\
\text { - Horace Annesley Vachell }\end{array}$ & 260 \\
\hline "Is It You, Mother?" & - & - & - & - & - Sidney Lee & \\
\hline The Fate of Flemish A & ART AT & T THE & HAND & DS OF KULT & TUR Arthur Morrison & \\
\hline The Graves of All Hi & Is HoP & PES & & - $\quad-$ & H. DeVere Stacpoole & \\
\hline \multicolumn{7}{|c|}{ "My Sixth Son Is Now Lying Here-Where Are } \\
\hline Yours?" & - & - & - & - & - H. DeVere Stacpoole & \\
\hline BUNKERED & - & - & - & - & - W.R. Inge & \\
\hline GOTT STRAFE VERDUN & - & - & - & - & - W.R. Inge & \\
\hline THE LAST THROW - & - & - & - & - & - E. Charles Vivian & \\
\hline THE ZEPPELIN BAG & - & - & - & - & - Clive Holland & \\
\hline "Come In, Michael, I & HAVE & HAD & A LOI & NG SLEEP" & Horace Annesley Vachell & \\
\hline BENCH - & - & - & - & - & Chesterton & \\
\hline What About Peace, La & ADS? & - & - & - & $-W$. & \\
\hline The Liberators - & - & & - & - & - Jose & \\
\hline Tom Thumb AND The G & IANT & - & - & - & - E. Charles Vivian & \\
\hline "We Have Finished O & FF THF & & SSIA & - & - E. Charles Vivian & \\
\hline MídDle Through - & - & 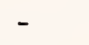 & - & - & - Clive Holland & \\
\hline My ENEMy Is My Best & FrIE & & - & - & - William Mitchell $\mathrm{K}$ & \\
\hline I DEAL With the & SMali & $\mathrm{L} F$ & & - & - Clive Holland & \\
\hline The Two Eagles - & - & 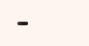 & - & - & - A. Shadwell & \\
\hline -INSIDE THE SA & AVOY & - & - & - & - E. Charles Vivian & \\
\hline OUTSIDE THE & SAVOY & & - & - & - E. Charles Vivian & \\
\hline THE INVOCATION - & - & & - & - & - A. Shadwell & \\
\hline
\end{tabular}




\section{Introduction}

OUIS RAEMAEKERS will stand out for all time as one of the supreme figures which the Great War has called into being. His genius has been enlisted in the service of mankind, and his work, being entirely sincere and untouched by racial or national prejudice, will endure; indeed, it promises to gain strength as the years advance. When the intense passions, which have been awakened by this world struggle, have faded away, civilization will regard the war largely through these wonderful drawings.

Before the war had been in progress many weeks the cartoons in the Amsterdam Telegraaf attracted attention in the capitals of Europe, many leading newspapers reproducing them. The German authorities, quick to realize their full significance, did all in their power to suppress them. Through German intrigue Raemaekers has been charged in the Dutch Courts with endangering the neutrality of Holland-and acquitted. A price has been set on his head, should he ever venture over the border.

When he crossed to England, his wife received anonymous post-cards, warning her that his ship would certainly be torpedoed in the North Sea. 'The Cologne Gazette, in a leading article on Holland, threatens that country that "after the War Germany will settle accounts with Holland, and for each calumny, for each cartoon of Raemaekers, she will demand payment with the interest that is due to her." Not since Saul and the men of Israel were in the valley of Elah fighting with the Philistines has so unexpected a champion arisen. With brush and pencil this Dutch painter will do even as David did with the smooth stone out of the brook: he will destroy the braggart Goliath, who, strong in his own might, defies the forces of the living God.

When Mr. Raemaekers came to London in December, he was received by the Prime Minister, and was entertained at a complimentary luncheon by the Journalists of the British capital. Similar honour was conferred on him on his second visit. He was the guest of honour at the Savage Club; the Royal Society of Miniature Painters elected him an Honorary Member. But it has been left to France to pay the most fitting recognition to his genius and to his services in the cause of freedom and truth. The Cross of the Legion of Honour has been presented to him, and on his visit to Paris this month a special reception is to be held in his honour at La Sorbonne, which is the highest purely intellectual reward Europe can confer on any man.

The great Dutch cartoonist is now in his forty-seventh year. He was born in Holland, his father, who is dead, having been the editor of a provincial newspaper. His mother, who is still alive and exceedingly proud of her son's fame, is a German 


\section{INTRODUTCTION}

by birth, but rejoices that she married a Dutchman. Mr. Raemaekers, who is short, fair, and of a ruddy countenance, looks at least ten years younger than his age. He took up painting and drawing when quite young and learnt his art in Holland and in Brussels. All his life he has lived in his own country, but with frequent visits to Belgium and Germany, where, through his mother, he has many relations. Thus he knows by experience the nature of the peoples whom he depicts.

For many years he was a landscape painter and a portrait painter, and made money and local reputation. Six or seven years ago he turned his attention to political work, and became a cartoonist and caricaturist on the staff of the Amsterdam Telegraaf, thus opening the way to a fame which is not only world-wide but which will endure as long as the memory of the Great War lasts. His ideas come to him naturally and without effort. Suggestions do not assist him; they hinder him when he endeavours to act on them. He is an artist to his finger-tips and throws the whole force of his being into his work. Some years ago he married a Dutch lady, who is devoted to music, and they have three children, two girls and a boy (the youngest); the eldest is now twelve. Very happy in his home, Mr. Raemaekers has no ambitions outside it, except to go on with his work. A Teuton paper has declared that Raemaekers' cartoons are worth at least two Army Corps to the Allies.

The strong religious tendency which so often distinguishes his work makes one instinctively ask to what Church does the artist belong. He replies that he belongs to none, but was brought up a Catholic, and his wife a Protestant, and the differences which in later life severed each from their early teaching caused them to meet on common ground. But the intense Christian feeling of these drawings is beyond cavil or dispute: they again and again bring home to the heart the vital truths of the Faith with irresistible force, and the artist ever expresses the Christianity, not perhaps of the theologian, but of the honest and kindly man of the world.

Praise has been bestowed upon his work by several German papers-qualified praise. The Leipziger Volkszeitung has declared that Raemaekers' cartoons show unimpeachable art and great power of execution, but that they all lack one thing. They have no wit, no spirit. Which is true - in a sense. They do lack wit-German wit; they do lack spirit-German spirit. And what German wit and German spirit may be one can comprehend by a study of Raemaekers' cartoons.

It has been well said that no man living amidst these surging seas of blood and tears has come nearer to the rôle of Peacemaker than Raemaekers. The Peace which he works for is not a matter of arrangement between diplomatists and politicians: it is the peace which the intelligence and the soul of the Western world shall insist on in the years to be. God grant it be not long delayed, but it can only come when the enemy is entirely overthrown and the victory is overwhelming and complete.

\author{
EMPIRE House, \\ KINGSWAY, LONDON. \\ February, 1916.
}

FRANCIS STOPFORD, EDITOR, Land and Water. 


\section{An Appreciation from the Prime Minister}

Downing Street,

Whitehall, S. W.

$\mathrm{M}$

R. RAEMAEKERS' powerful work gives form and colour to the menace which the Allies are averting from the liberty, the civilization, and the humanity of the future. He shows us our enemies as they appear to the unbiassed eyes of a neutral, and wherever his pictures are seen determination will be strengthened to tolerate no end of the war save the final overthrow of the Prussian military power.

Signed H. H. ASQUITH. 


\section{Christendom After Twenty Centuries}

$\mathrm{T}$

HESE pictures, with their haunting sense of beauty and their biting satire, might almost have been drawn by the finger of the Accusing Angel. As the spectator gazes on them the fuli weight of the horrible cruelty and senseless futility of war overwhelms the soul, and, sinking helplessly beneath it, he feels inclined to assume the same attitude of despair as is shown in "Christendom After Twenty Centuries.',

"War is war," the Germans preached and practised, and no matter how clement and correct may be the humanity of the Allies, we realize through these pictures what the human race has to face and endure once peace be broken. Is "Christendom After Twenty Centuries" to be even as Christianity was in the first century - an excuse for the perpetralion of mad cruelties by degenerate Casars or Kaisers (spell it as you will) at their games? Cannot the-higher and liner attributes of mankind be developed and strengthened without this apparently needless waste of agony and life? Is human nature only to be redeemed through the Cross, and must Calvary bear again and again its heavy load of human anguish?

One cannot escape from this inner questioning as one gazes on Raemaekers' cartoons.

FRANCIS STOPFORD. 


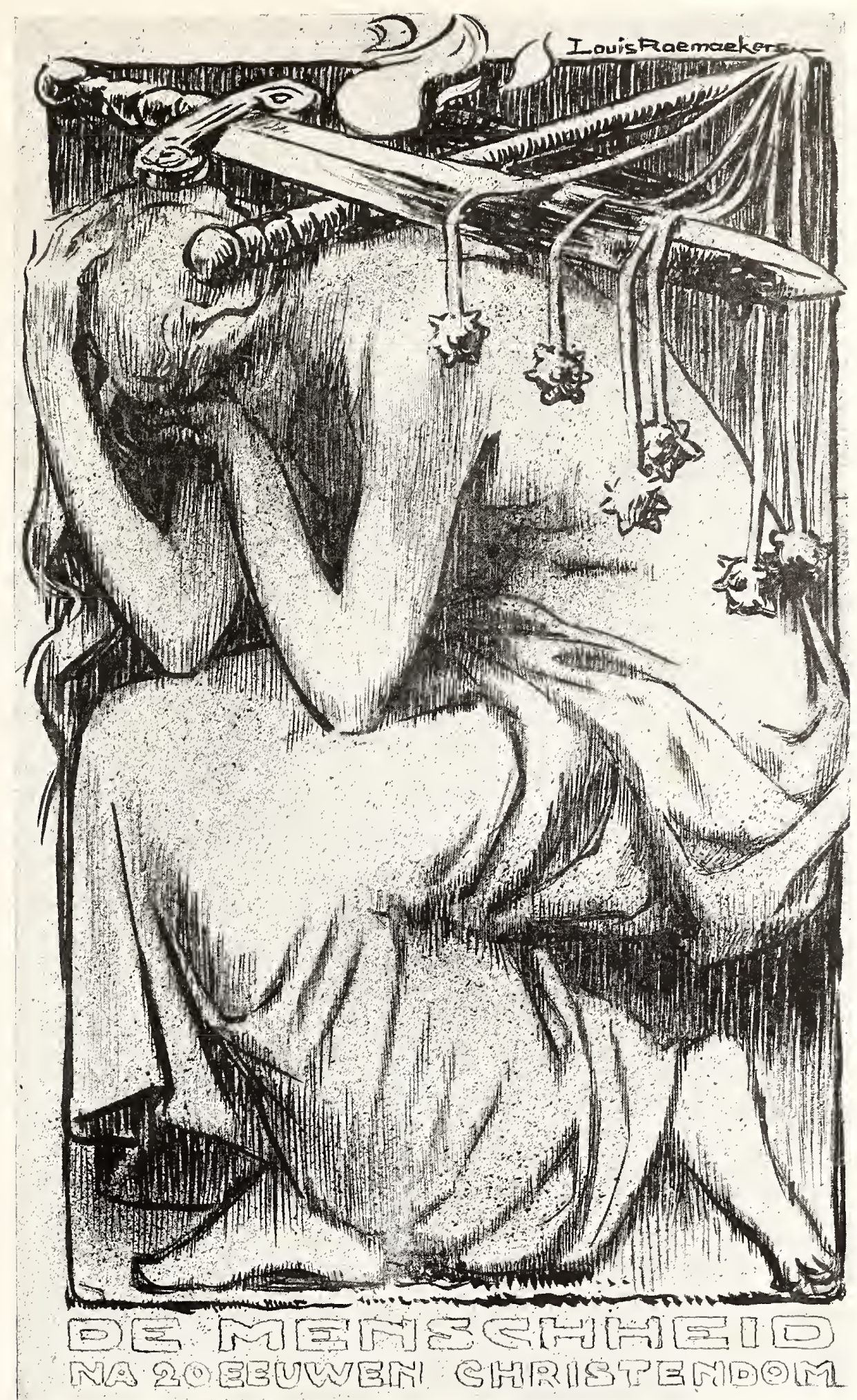

CHRISTENDOM AFTER TWENTY CENTURIES 


\section{A Stable Peace}

W

ERE I privileged to have a hand at the Peace Conference, my coöperation would take the part of deeds and I should only ask to hang the walls of the council chamber with life-size reproductions of Raemaekers in blood-red frames. For human memory is weak, and as mind of man cannot grasp the meaning of a million, so may it well fail to keep steadily before itself the measure of Belgium - the rape and murder, the pillage and plunder, the pretences under which perished women and priests and children, the brutal tyranny-the left hand that beckoned in friendly fashion, the right hand, hidden with the steel.

We can very safely leave France to remember Northern France and Russia not to forget Poland; but let Belgium and Serbia be at the front of the British mind and conscience; let her lift her eyes to these scorching pictures when Germany fights with all her cunning for a peace that shall leave Prussia scotched, not killed.

Already one reads despondent articles, that the English tradition, to forgive and forget, is going to wreck the peace; and students of psychology fear that within us lie ineradicable qualities that will save the situation for Germany at the end.

To suspect such a national weakness is surely to arm against it and see that our contribution to the Peace Conference shall not stultify our contribution to the War.

The Germans have been kite-flying for six months, to see which way the wind blows; and when the steady hurricane broke the strings and flung the kites headlong to earth, those who sent them up were sufficiently proclaimed by their haste to disclaim.

But when the actual conditions are created and the new "Scrap of Paper" comes to light, since German honour is dead and her oath in her own sight worthless, let it be worthless in our sight also, and let the terms of peace preclude her power to perjure herself again. Make her honest by depriving her of the strength to be dishonest. There is only one thing on earth the German will ever respect, and that is superior force. May Berlin, therefore, see an army of occupation; and may "peace" be a word banished from every Allied tongue until that preliminary condition of peace is accomplished, and Germany sees other armies than her own.

Reason has been denied speech in this war; but if she is similarly banished from the company of the peace-makers, then woe betide the constitution of the thing they will create, for a "stable peace" must be the very last desire of those now doomed to defeat.

EDEN PIILLPOTTS. 


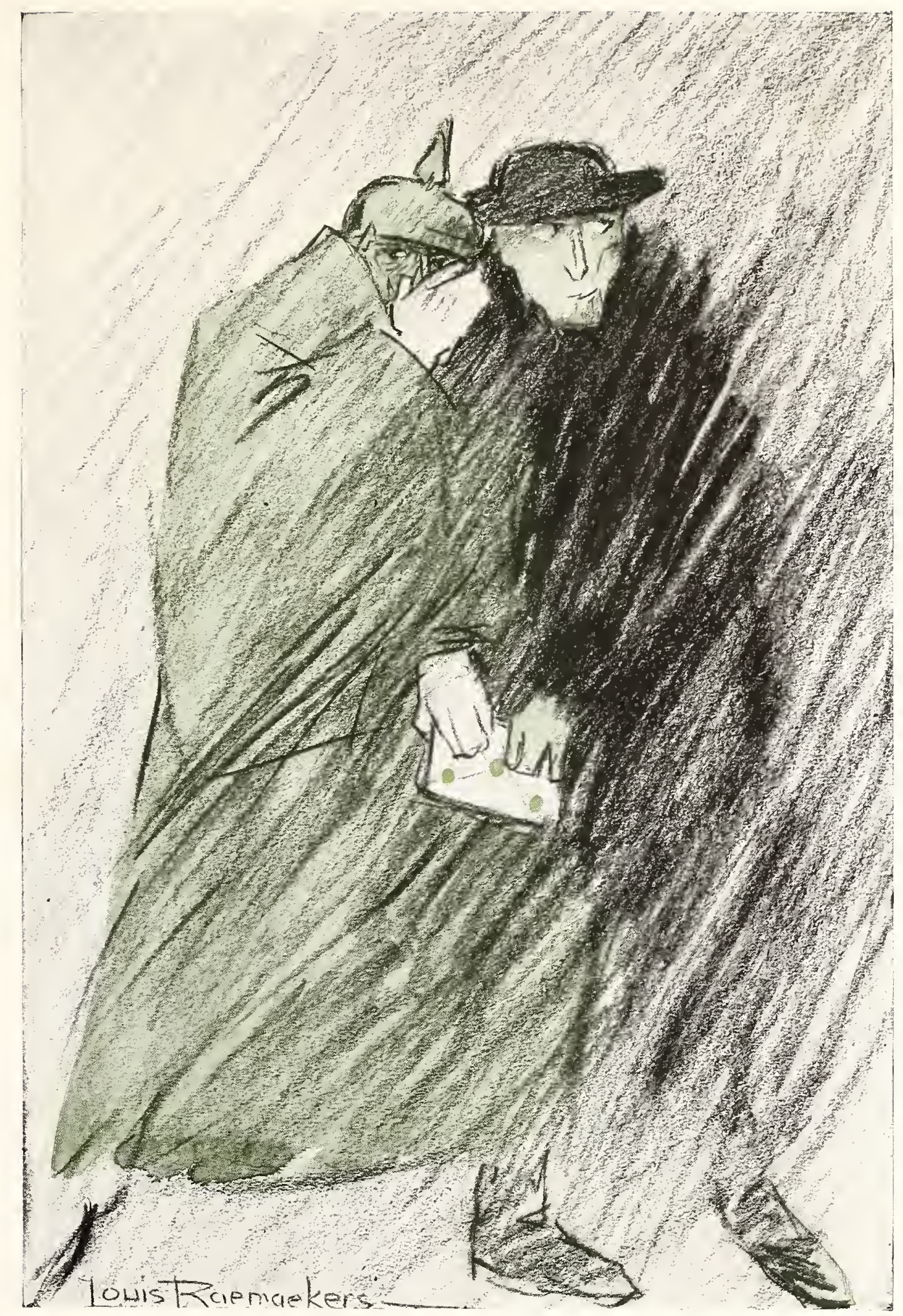

A STABLE PEACE

The Kaiser: "And remember, if they do not accept, I deny altogether." 


\section{The Massacre of the Innocents}

S

OME "neutrals," and even some of the people here in England, still doubt the reality of the German atrocities in Belgium, but Raemaekers has seen and spoken with those to whom the scene depicted in this cartoon is an ugly reality. One who would understand it to the full must visualize the hands behind the thrusting rifle butts, and the faces behind the hands, as well as the praying, maddened, despairing, vengeful women of the picture-and must visualize, too, the men thrust back another way, to wait their fate at the hands of these apostles of a civilization of force.

Yet even then full realization is impossible; the man whose pencil has limned these faces has only caught a far-off echo of the reality, and thus we who see his picture are yet another stage removed from the full horror of the scene that he gives us. Not on us, in England, have the rifle butts fallen; not for us has it chanced that we should be shepherded "men to the right, women to the left"; not ours the trenched graves and the extremity of shame. Thus it is not for us to speak, as the people of Belgium and Northern France will speak, of the limits of endurance, and of war's last terrors imposed on those whom war should have passed by and left untouched. We gather, dimly and with but a tithe of the feeling that experience can impart, that these extremities of shame and suffering have been imposed on a people that has done no wrong, and we may gain some slight satisfaction from the thought that to this nation is apportioned a share in the work of vengeance on the criminals.

E. CHARLES VIVIAN. 


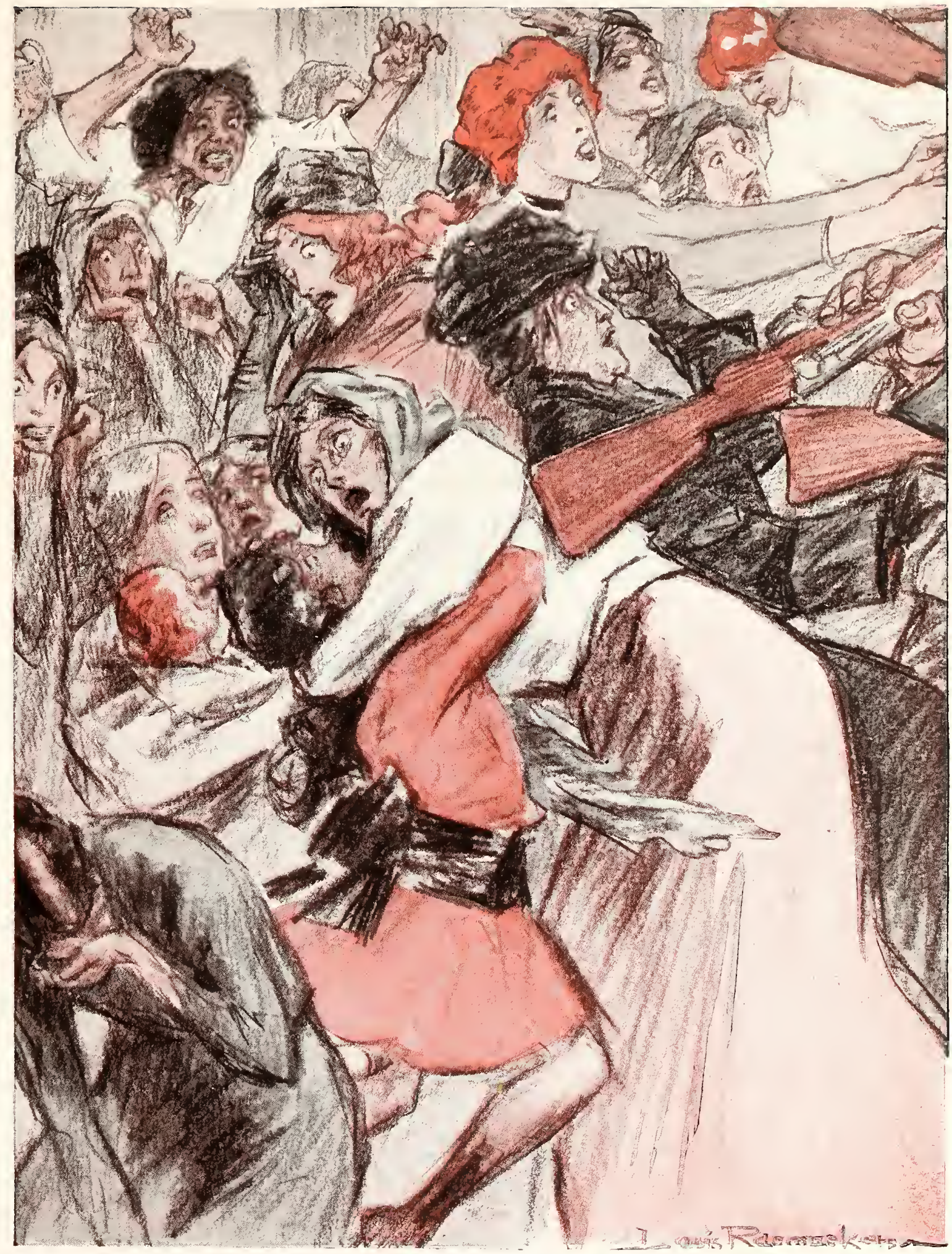

THE MASSACRE OF THE INNOCENTS

"We must do everything in good order-so men to the right, women to the left." 


\section{Bernhardiism}

I

$T$ IS the most bestial part of this most bestial thing that it is calculated and a matter of orders. The private soldier takes his share of the loot, and is generally the instrument of the cold and ordered killing; but it is the officer-class which most profits in goods, and it is the higher command which dictates the policy. It was so in 1870. It is much more so to-day.

This note of calculation is particularly to be seen in the fluctuations through which that policy has passed. When the enemy was absolutely certain of victory, outnumbering the invader by nearly two to one and sweeping all before him, we had massacres upon massacres: Louvain, Aerschot, the wholesale butchery of Dinant, the Lorraine villages (and in particular the hell of Guébervilliers). Even at the very extremity of his tide of invasion, and in the last days of it, came the atrocities and destruction of Sermaize. In the very act of the defeat which has pinned him and began the process of his destruction he was attempting yet a further repetition of these unnameable things at Senhis under the very gates of Paris.

Then came the months when he felt less secure. The whole thing was at once toned down by order. Pillage was reduced to isolated cases, and murder also. Few children suffered.

A recovery of confidence throughout his Eastern successes last summer renewed the crimes. Poland is full of them, and the Serbian land as well.

In general, you have throughout these months of his ordeal a regular succession, of excess in vileness when he is confident, of restraint in it when he is louched by fear.

This effect of fear upon the dull soul is a characteristic familiar to all men who know their Prussian from history, particularly the wealthier governing classes of Prussia. It is a characteristic which those who are in authority during this war will do well to bear in mind. Properly used, that knowledge may be made an instrument of victory.

HILAIRE BELLOC. 


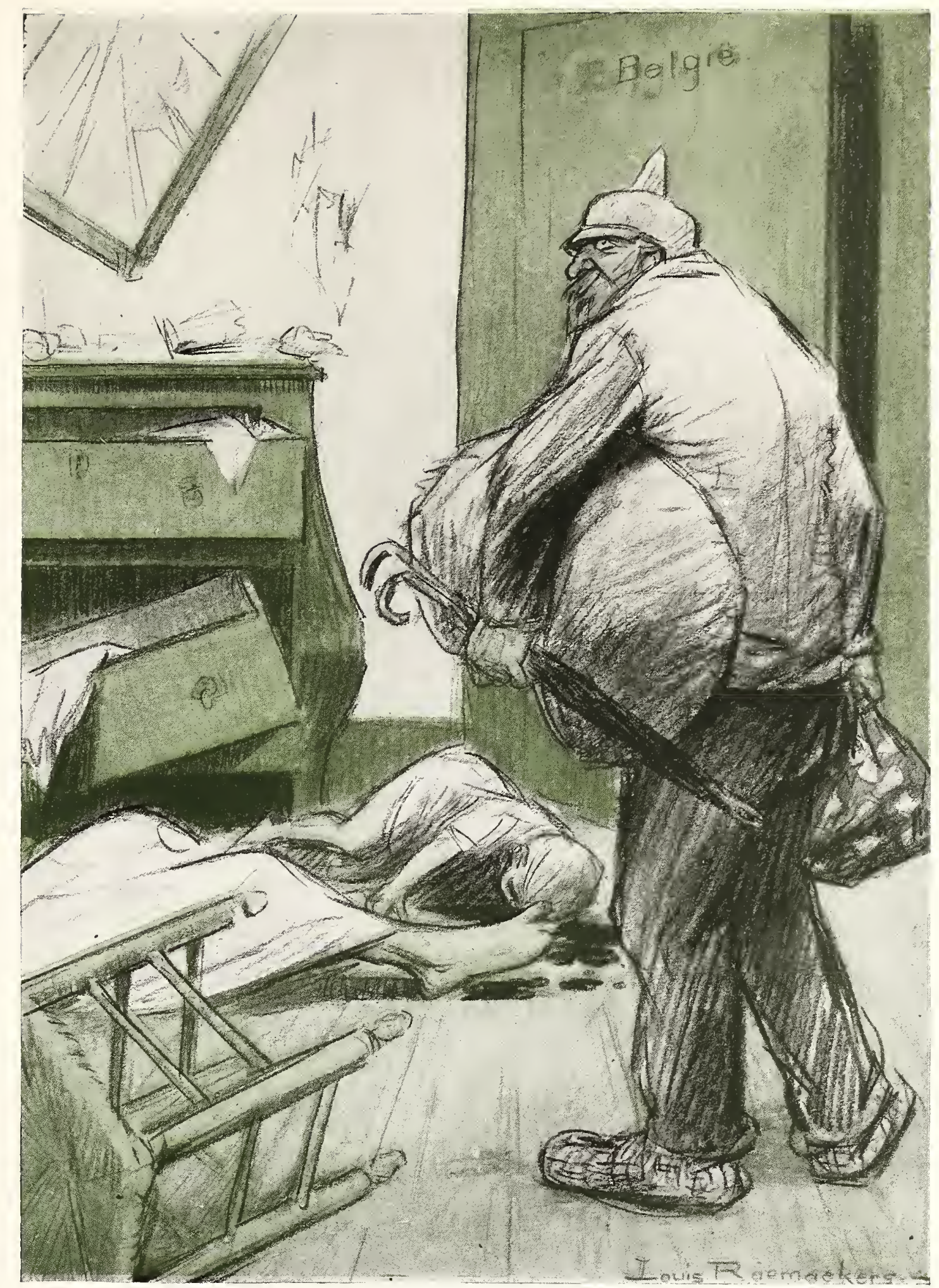

BERNHARDIISM

"It's all right. If I hadn't done it some one else might." 


\section{From Liège to Aix-La-Chapelle}

$\mathrm{M}$

OREOVER, by the means of Wisdom I shall obtain immortality, and leave behind me an everlasting memorial to them that come after me.

"I shall set the people in order, and the nations shall be subject unto me.

"Horrible tyrants shall be afraid, when they do but hear of me; I shall be found good among the multitude, and valiant in war." (Wisdom viii. $13,14,15$.)

Wisdom and Wisdom alone could have painted this terrible picture-the most terrible perhaps which Raemaekers has ever done and yet the simplest. That he should have dared to leave almost everything to the imagination of the beholder is evidence of the wonderful power which he exercises over the mind of the people. Each of us knows what is in that goods-van and we shudder at its hideous hidden freight, fearing lest it may be disclosed before our eyes. Wisdom is but another name for supreme genius. So apposite are the verses which are quoted here from "The Wisdom of Solomon" in the "Apocrypha" that they seem almost to have been written on Louis Raemaekers.

Moreover, this picture brings home to all of us in the most forcible manner possible the full reality of the horror of war.

FRANCIS STOPFORD. 


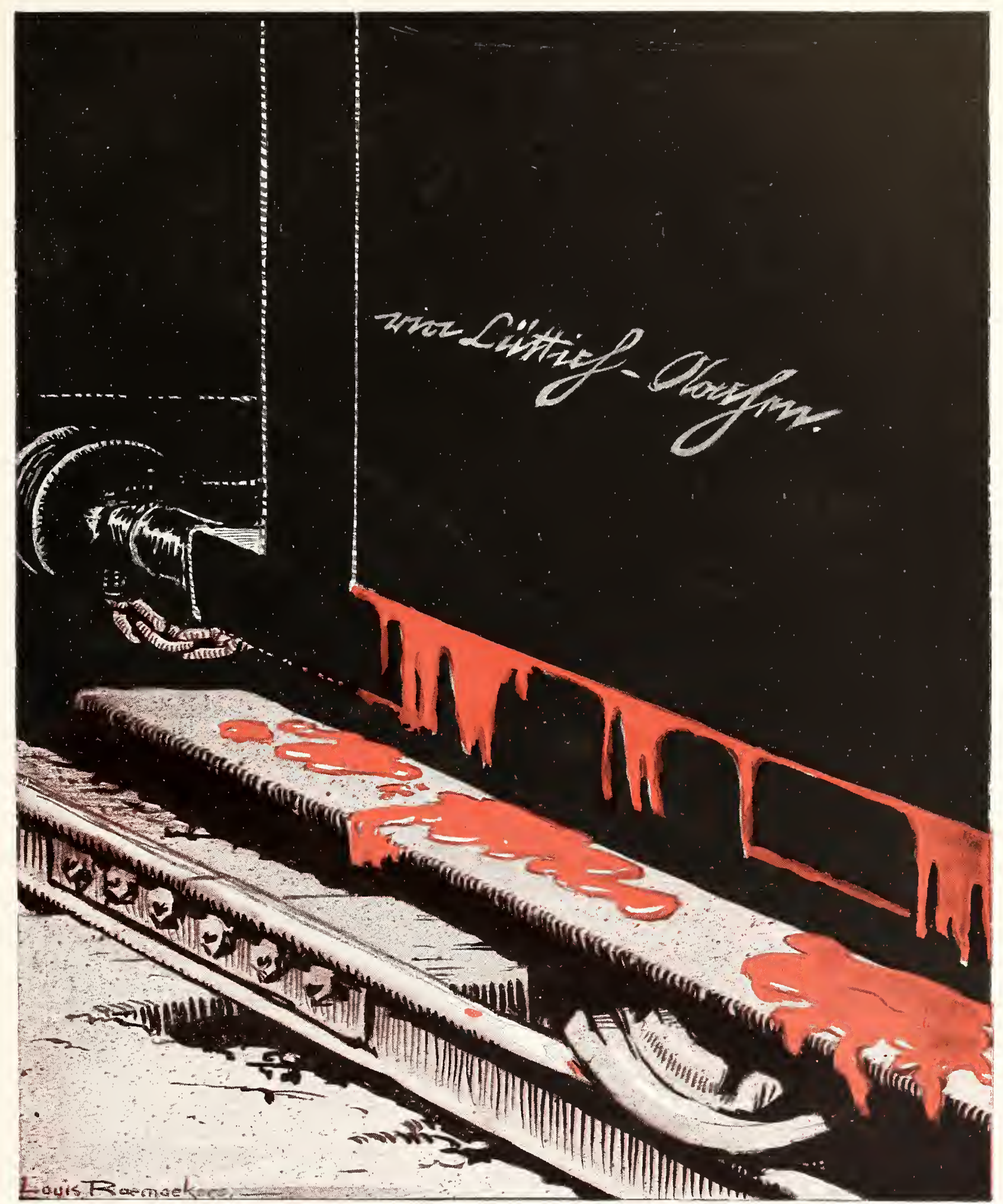

FROM LIËGE TO AIX-LA-CHAPELLE 


\section{Spoils for the Victurs}

$\mathrm{T}$ HE feature that will stamp Prussian War forever, and make this group of campaigns stand out from all others, is the character of its murder and pillage.

Of all the historical ignorance upon which the foolish Pacifist's case is founded, perhaps the worst is the conception that these abominations are the natural accompaniment of war. They have attached to war when war was ill organised in type. But the more subject to rule it has become, the more men have gloried in arms, the more they have believed the high trade of soldier to be a pride, the more have they eliminated the pillage of the civilian and the slaughter of the innocent from its actions. Those things belong to violent passion and to lack of reason. Modern war and the chivalric tradition scorned them.

The edges of the Germanies have, in the past, been touched by the chivalric tradition: Prussia never. That noblest inheritance of Christendom never reached out so far into the wilds. And to Germany, now wholly Prussianized — which will kill us or which we shall kill-soldier is no high thing, nor is their any meaning attached to the word "Gloricus." War is for that State a business: a business only to be undertaken with profit against what is certainly weaker; to be undertaken without faith and with a cruelty in proportion to that weakness. In particular it must be a terror to women, to children, and to the aged-for these remain unarmed.

This country alone of the original alliance has been spared pillage. It has not been spared murder. But this country, though the process has perhaps been more gradual than elsewhere, is very vividly alive to-day to what would necessarily follow the presence of German soldiery upon English land.

HILAIRE BELLOC. 


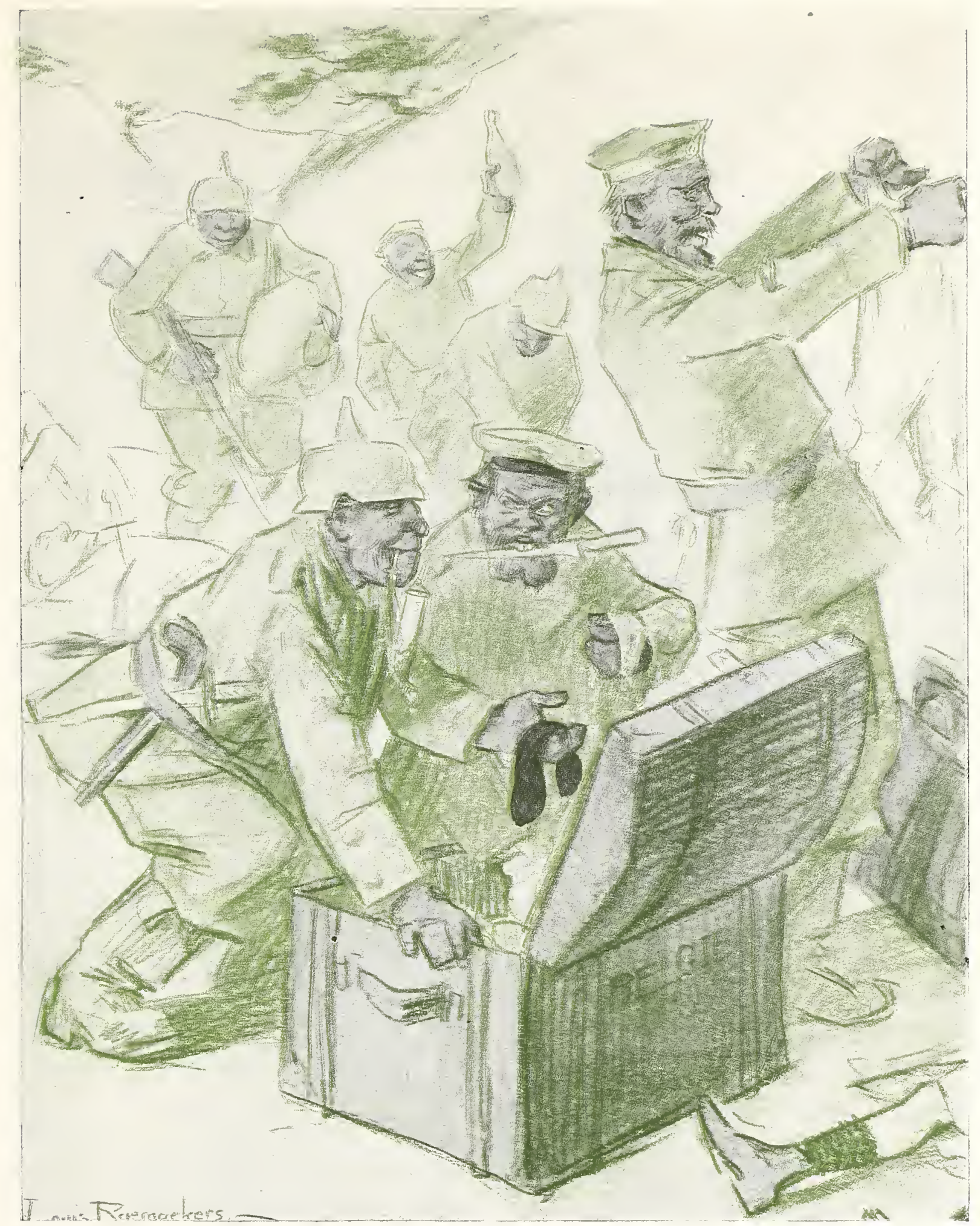

SPOILS FOR THE VICTORS

"We must despoil Belgium if only to make room for our own culture." 


\section{The Very Stones Cry Out}

I

F THE highly organized enemy with whom we are at grips in a life-and-death struggle would only play the war game in accordance with the rules drawn up by civilized peoples, he would, indeed, command our admiration no less than our respect. Never on this earth was there such a splendid fighting machine as that "made in Germany." The armies against us are the last word in discipline, fitness, and equipment; and are led by men who, born in barracks, weaned on munitions, have but one aim and end in view-"WorldDominion or Downfall."

As a matter of fact, instead of winning our admiration they have drawn our detestation. Not content with brushing aside all international laws of warfare, they have trampled upon every law, human and divine, standing in their way of conquest. Indeed, Germany's method of fighting would disgrace the savages of Central Africa.

Prussianized Germany has the monopoly of "frightfulness." When not "frightful," Prussian troopers are not living down to the instructions of their War-lords to leave the conquered with nothing but eyes to weep with. Not content to crucify Canadians, murder priests, violate nuns, mishandle women, and bayonet children, the enemy torpedoes civilian-carrying liners, and bombs Red Cross hospitals. More, sinning against posterity as well as antiquity, Germans stand charged before man and God with reducing to ashes some of the finest artistic output of Christian civilization. When accused of crimes such as these, Germany answers through her generals: "The commonest, ugliest stone put to mark the burial-place of a German grenadier is a more glorious and venerable monument than all the cathedrals of Europe put together" (General von Disfurth in Hamburger Nachrichten). "Thus is fulfilled the well-known prophecy of Heine: 'When once that restraining talisman, the Cross, is broken . . . Thor, with his colossal hammer, will leap up, and with it shatter into fragments the Gothic cathedrals" (Religion and Philosophy in Germany in the Nineteenth Century).

What, I ask, can you do with such people but either crush or civilize them?

The very stones cry out against them.

BERNARD VAUGHAN, S.J. 


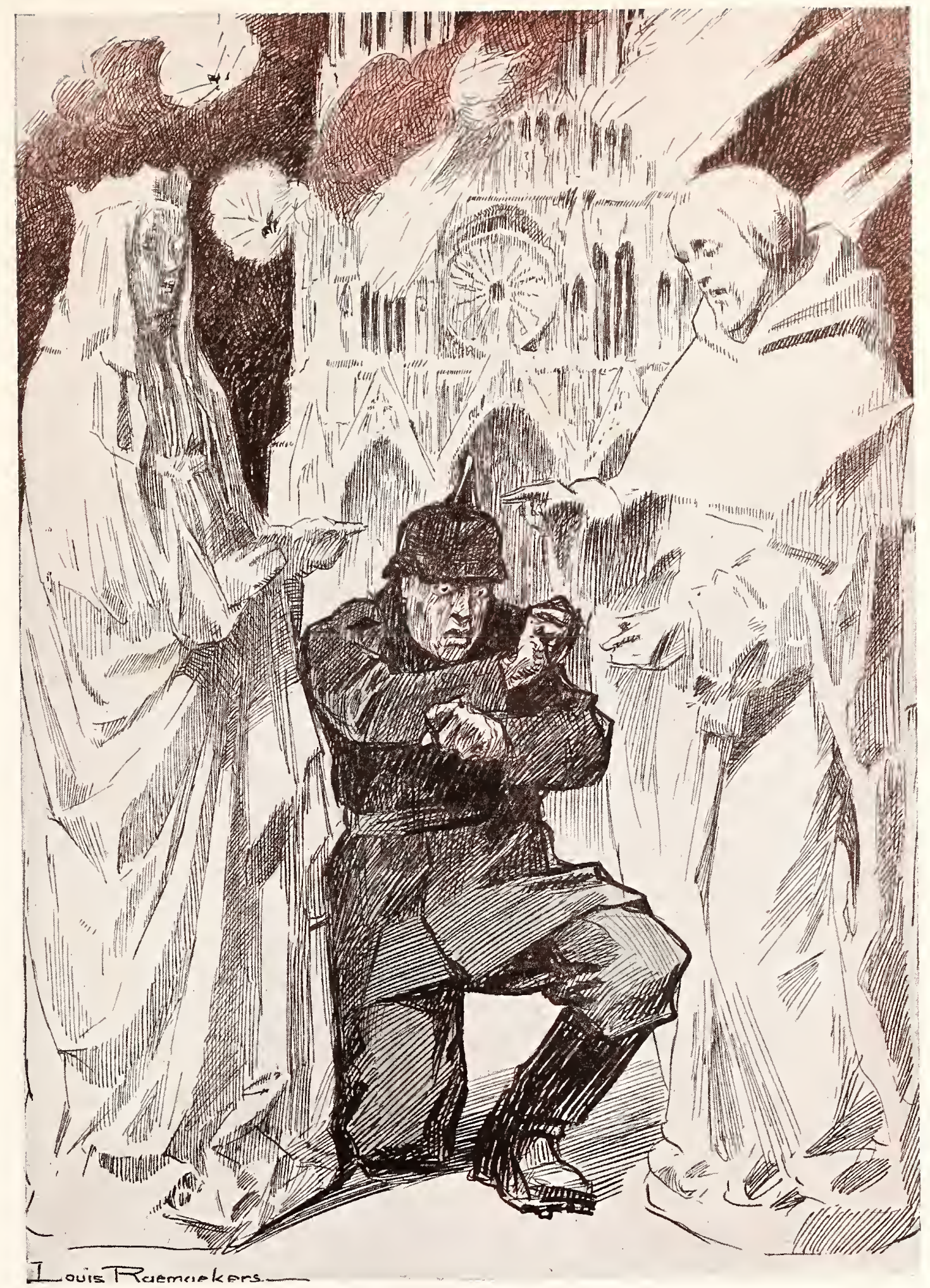

THE VERY STONES CRY OUT 


\section{Satan's Partner}

THE cartoon bears the quotation from Bernhardi "War is as divine as eating and drinking." Yes; and German war is as divine as German eating and drinking. Any one who has been in a German restaurant during that mammoth midday meal which generally precedes a sleep akin to a hibernation, will understand how the same strange barbarous solemnity has ruined all the real romance of war. There is no way of conveying the distinction, except by saying vaguely that there is a way of doing things, and that butchering is not necessary to a good army any more than gobbling is necessary to a good dinner. In our own insular shorthand it can be, insufficiently and narrowly but not unprofitably, expressed by saying that it is possible both to fight and to eat like a gentleman. It is therefore highly significant that Mr. Raemaekers has in this cartoon conceived the devil primarily as a kind of ogre. It is a matter of great interest that this Dutch man of genius, like that other genius whose pencil war has turned into a sword, Will Dyson, tends in the presence of Prussia (which has been for many moderns their first glimpse of absolute or positive evil) to depriving the devil of all that moonshine of dignity which sentimental sceptics have given him. Evil does not mean dignity, any more than it means any other good thing. The stronger caricaturists have, in a sense, fallen back on the medieval devil; not because he is more mystical, but because he is more material. The face of Raemaekers' Satan, with its lifted jowl and bared teeth, has less of the half-truth of cynicism than of mere ignominious greed. The armies are spread out for him as a banquet; and the war which he praises, and which was really spread for him in Flanders, is not a Crusade but a cannibal feast.

G. K. CHESTERTON. 


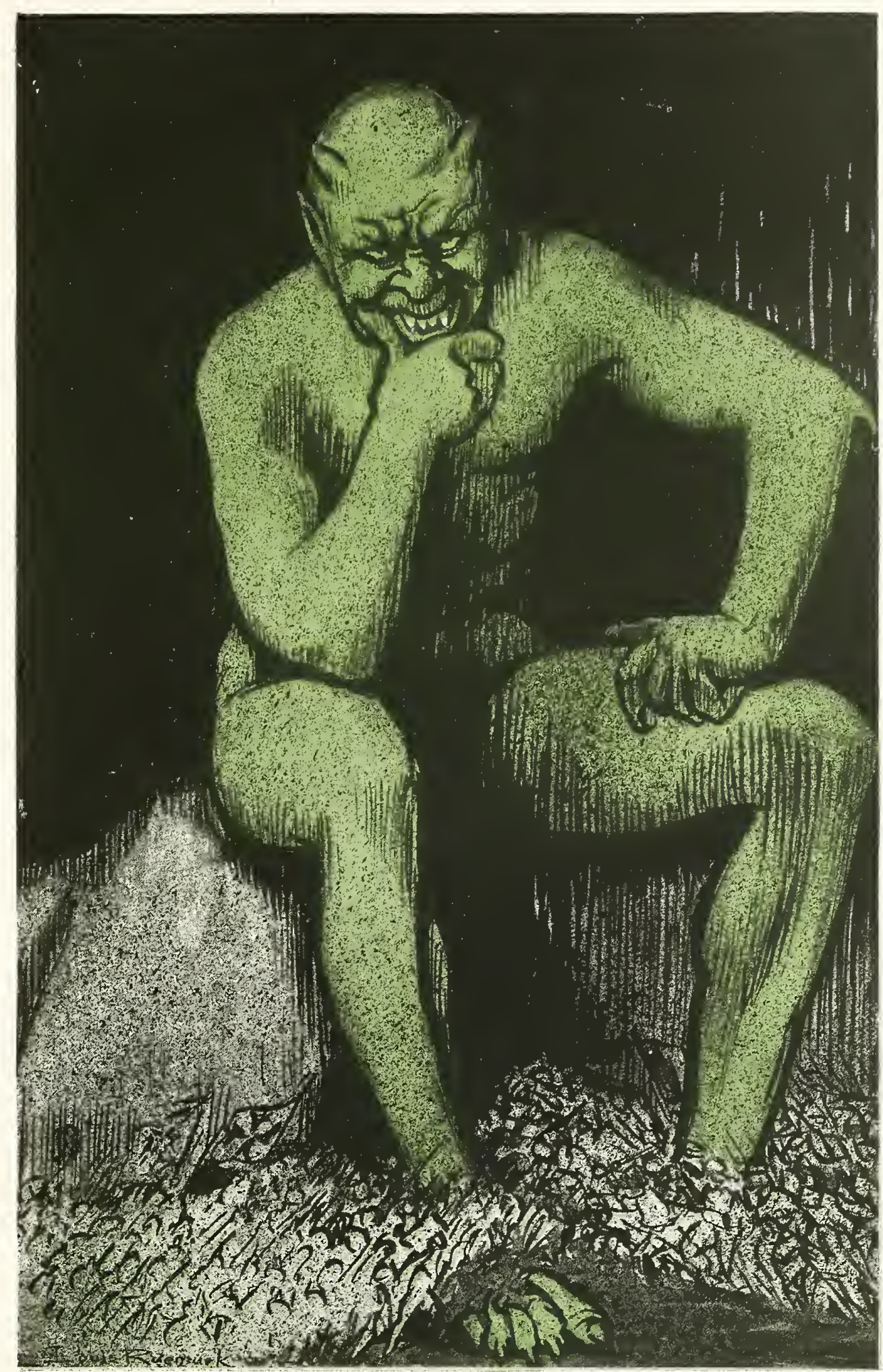

SATAN'S PARTNER

Bernhardi: "War is as divine as eating and drinking," SATAN: "Here is a partner for me." 


\section{Thrown to the Swine}

TIE Germans have committed many more indefensible crimes than the military execution of the kind-hearted nurse who had helped war-prisoners to escape. They have murdered hundreds of women who had committed no offence whatever against their military rules. But though not the worst of their misdeeds, this has probably been the stupidest. It gained us almost as many recruits as the sinking of the Lusitania, and it made the whole world understand - what is unhappily the truth-that the German is wholly destitute of chivalry. He knows indeed that people of other nations are affected by this sentiment; but he despises them for it. Woman is the weaker vessel; and therefore, according to his code, she must be taught to know her place, which is to cook and sew, and produce "cannonfodder" for the Government. Readers of Schopenhauer and Nietzsche will remember the advice given by those philosophers for the treatment of women. Nietzsche recommends a whip. It never occurred to German officialdom that the pedantic condemnation of one obscure woman, guilty by the letter of their law, would stir the heart of England and America to the depths, and steel our soldiers to further efforts against an enemy whose moral unlikeness to ourselves becomes more apparent with every new phase in the struggle.

THE DEAN OF ST. PAUL'S. 


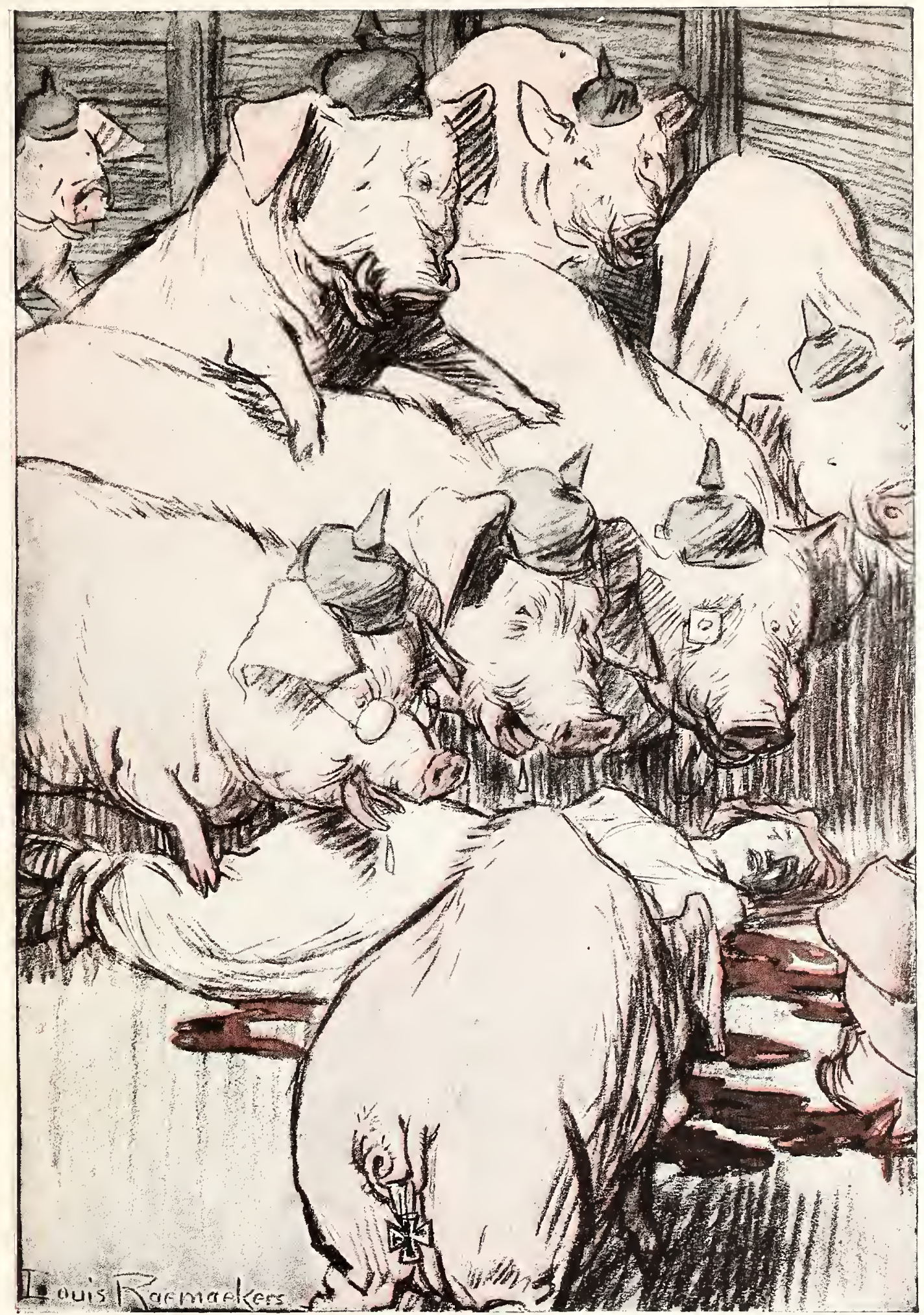

THROWN TO THE SWINE

The Martyred Nurse. 


\section{The Land Mine}

W

HAT does this cartoon suggest? I am asked and I ask myself. At first very little, almost nothing, only uninteresting, ugly death, gloomy, ghastly, dismal, but dull and largely featureless, blank and negalive. Has the artist's power failed him? No, it is strongly drawn. Has his inspiration? What does it mean? Is it indeed meant? As I gaze and pore on it longer, I seem to see that it is just in this blank negation that its strength and its suggestion lie. It is meant. It has meaning. A blast has passed over this place, and this is its sequel, its derelict rubbish.

It is death unredeemed, death with no very positive suggestion, with no hint of heroism, none of heroic action, little even of heroic passion; just death, helpless, hopeless, pointing to nothing but decomposition, decay, disappearance, anéantissement, reduction of the fair frame of life to nothingness. That is the peculiar horror of this war. Were the picture, as it well might be, even more hideous, and did it suggest something more definite, a story of struggle, say, recorded in contortion, or by wounds and weapons, it might be better.

But men killed by machines, men killed by natural forces unnaturally employed, are indeed a fact and a spectacle squalid, sorry, unutterably sad.

All wars have been horrible, but modern wars are more in extremes. Heroism is there, but not always. It is possible only in patches. There is much of the mere sacrifice of numbers. Strictly, there are scenes far worse than this, for death unredeemed is not the worst of sufferings or of ills. But few are sadder. This is indeed war made by those who hold it and will it to be "not a sport, but a science." There is no sport here. Men killed like this are like men killed by plague or the eruption of a volcano. And, indeed, what else are they? They are victims of a diseased humanity of the eruption-literal and metaphorical-of its hidden fires. And wars will grow more and more like this. What can stop them and banish these scenes? Only the hate of hate, only the love that can redeem even such a sight as this when at last we remember that it is for love's sake only that flesh and blood are in the last retort content to endure it.

HERBERT WARREN. 


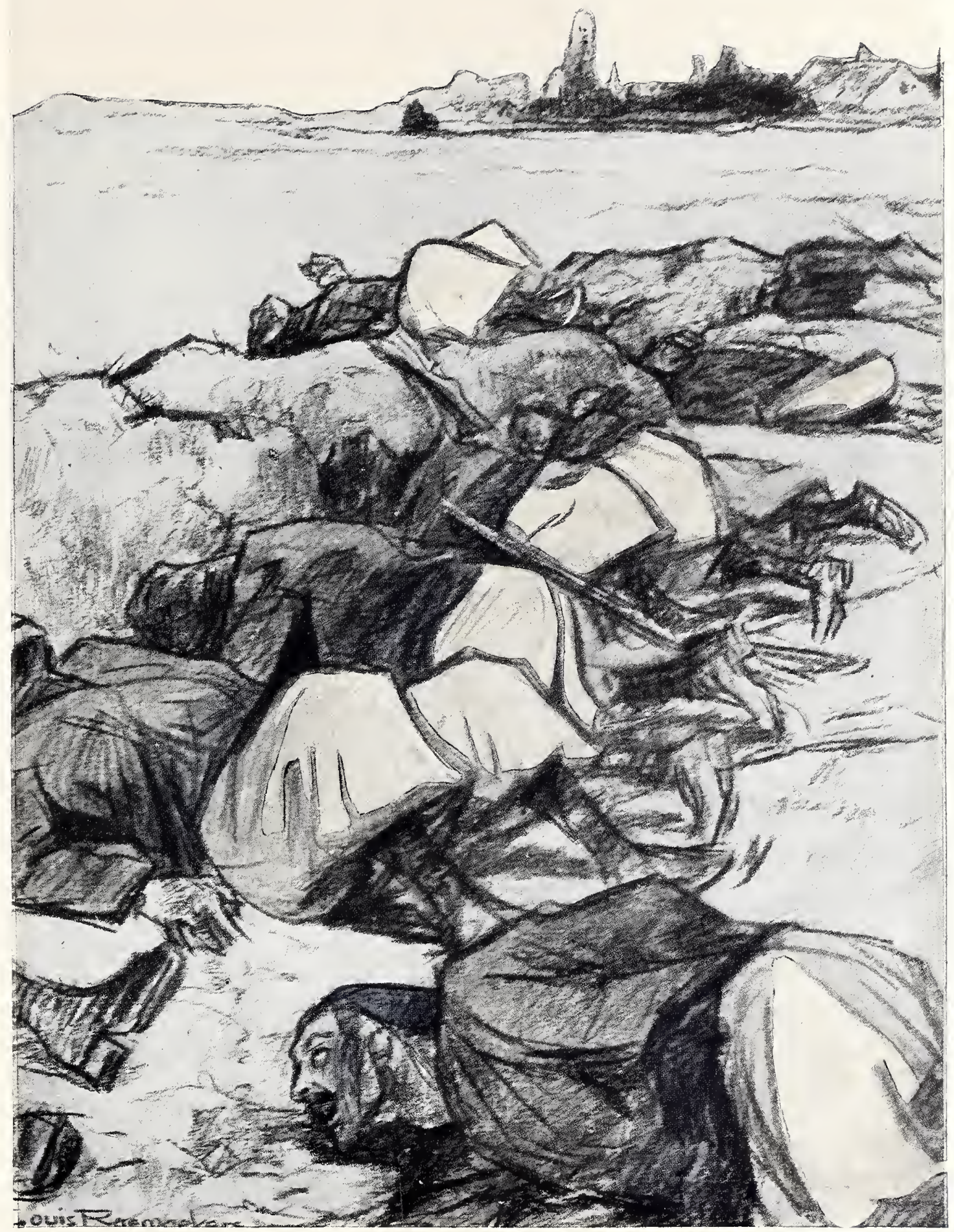

THE LAND MINE 


\section{"For Your Motherland"}

England's your Mother! Let your life acclaim

Her precious heart's blood flowing in your heart;

Take ye the thunder of her solemn name

Upon your lips with reverence; play your part

By word and deed

To shield and speed

The far-flung splendour of her ancient fame.

England's your Mother! Shall not you, her child,

Quicken the everlasting fires that glow

Upon your birthright's altar? England smiled

Beside your cradle, trusting you to show,

With manhood's might,

The undying light

That points the road her free-born spirits go.

England's your Mother! Man, forget it not

Wherever on the wide-wayed earth your fate

Calls you to labour; whatsoe'er your lot-
In service, or in power, in stress or state-

Whate'er betide,

With humble pride,

Remember! By your Mother you are great.

England's your Mother! What though dark the day

Above the storm-swept frontier that you tread?

Her vanished children throng the glorious way;

A myriad legions of her living deadThose starry trains

That shared your pains-

Shall set their crown of light upon your head.

England's your Mother! When the race is run

And you are called to leave your life and die,

Small matter what is lost, so this be won:

An after-glow of blessed memory, Gracious and pure, In witness sure

"England was this man's Mother: he, her son."

EDEN PHILLPOTTS. 


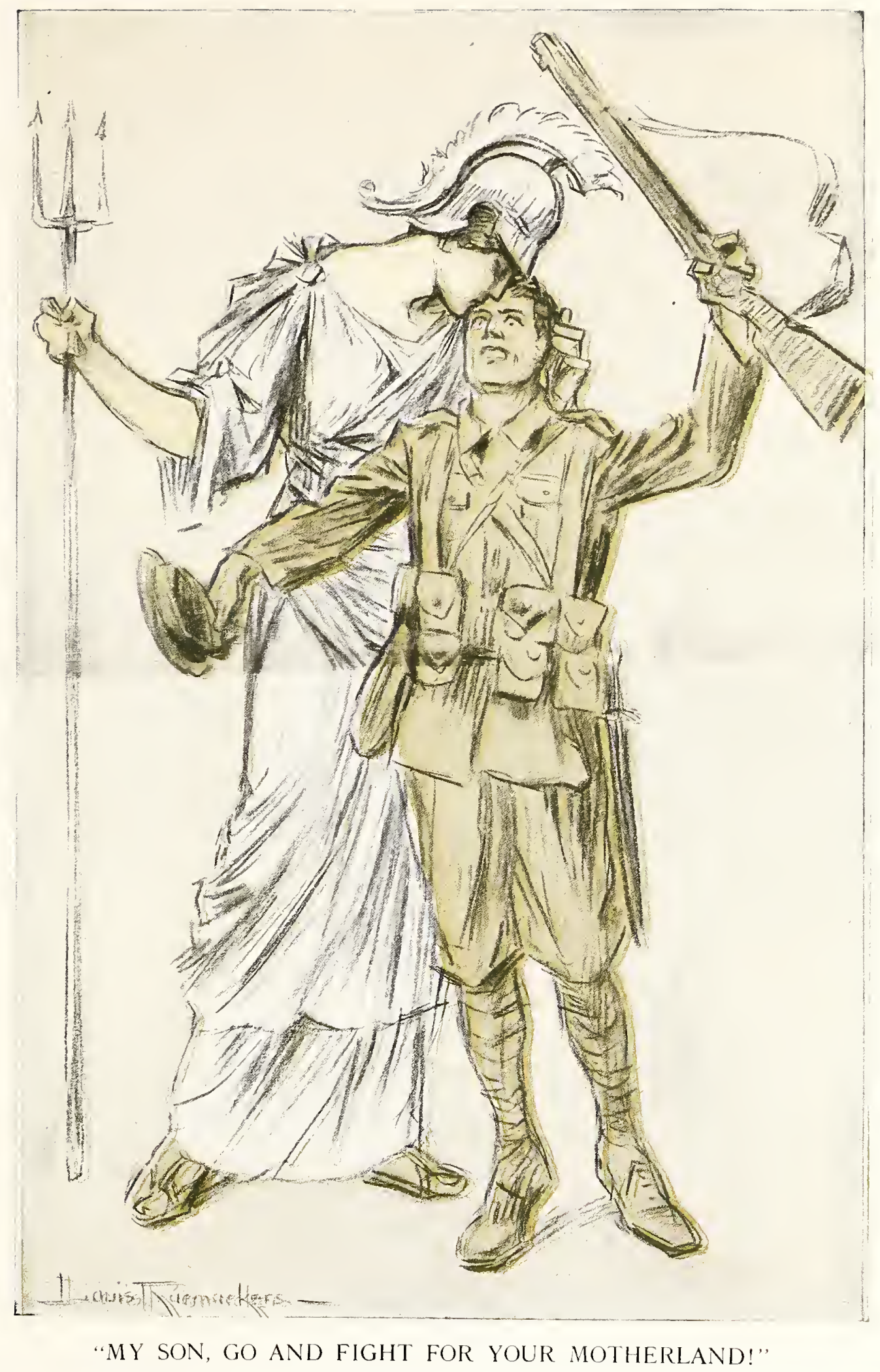




\section{The German Loan}

T HE bubble is very nicely balanced, for German "kultur," which is in reality but another word for "system" or "organization," rather than that which English-speaking people understand by "culture," has built up a system of internal credit that shall ensure the correct balance of the bubble-for just as long as the militarist policy of Germany can endure the strain of war. But money alone is not sufficient for victory; the peasant hard put to it to suppress his laugh, and the crowned Germania that built up the paper pedestal of the bubble, needed many other things to make that pedestal secure; there was needed integrity, and the respect of neighbouring nations, and the understanding of other points of view beside the doctrine of force, and liberty instead of coercion of a whole nation, and many other things that the older civilizations of Europe have accepted as parts of their code of life-the things this new, upstart Germany has not had time to learn. Thus, with the paper credit-and even with the gold reserve of which Germany has boasted, the pedestal is but paper. And the winds that blow from the flooded, corpse-strewn districts of the Yser, from Artois, from Champagne and the Vosges hills and forests, and from the long, long line of Russia's grim defences -these winds shall blow it away, leaving a nation bankrupt not only in money, but in the power to coerce, in the power to inspire fear, and in all those things out of which the Hohenzollern dynasty has built up the last empire of force.

E. GHARLES VIVIAN. 


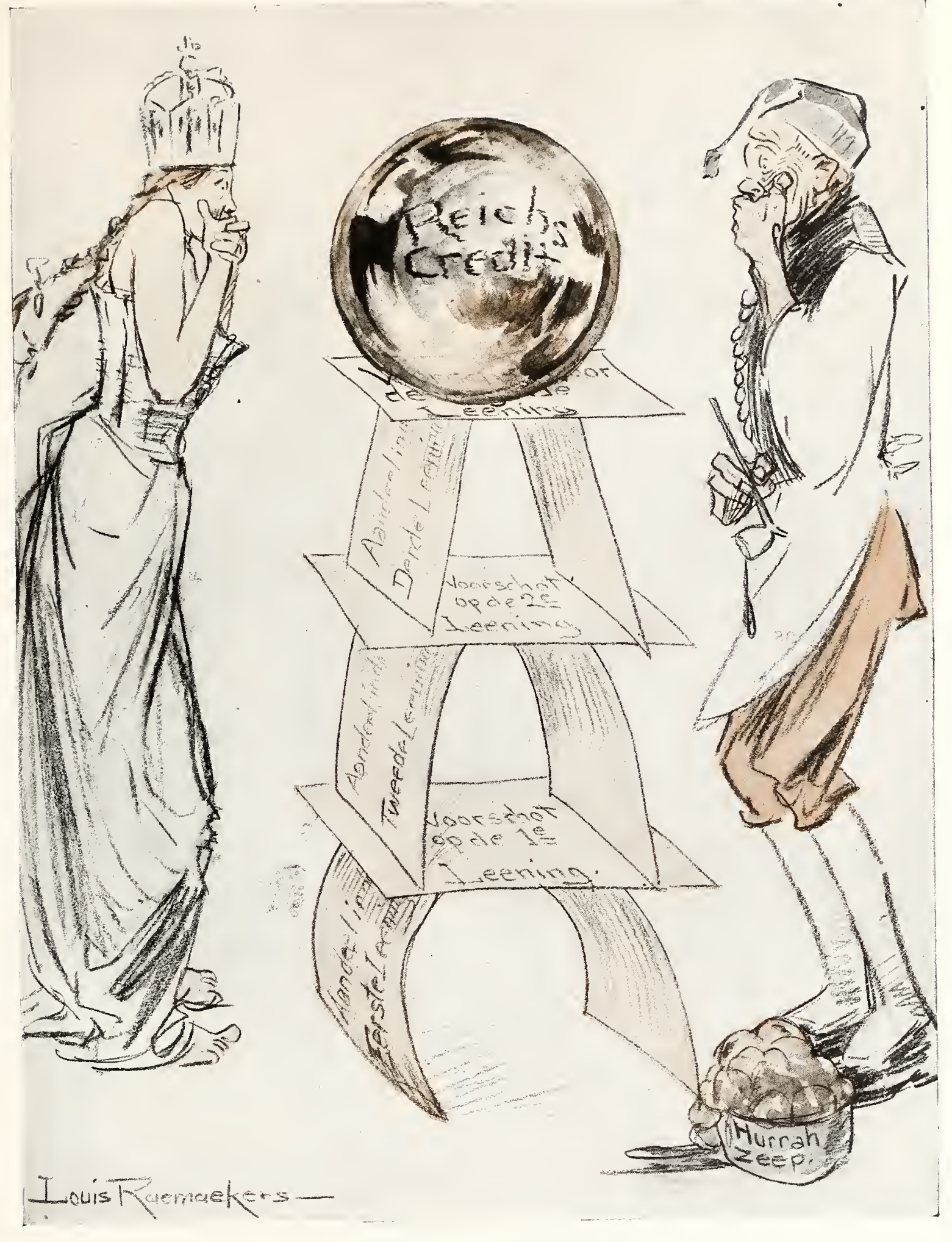

THE GERMAN LOAN

"Don't breathe on the bubble or the whole will collapse." 


\section{Europe, 1916}

T

HERE are some English critics who have not yet considered so simple a thing as that the case against horrors must be horrible. In this respect alone this publication of the work of the distinguished foreign cartoonist is a thing for our attention and enlightenment. It is the whole point of the awful experience which has to-day swallowed up all our smaller experiences, that we are in any case confronted with the abominable; and the most beautiful thing we can hope to show is only an abomination of it. Nevertheless, there is horror and horror. The distinction between brute exaggeration and artistic emphasis could hardly be better studied than in Mr. Raemaekers' cartoon, and the use he makes of the very ancient symbol of the wheel. Europe is represented as dragged and broken upon the wheel as in the old torture; but the wheel is that of a modern cannon, so that the dim background can be filled in with the suggestion of a wholly modern machinery. This is a very true satire; for there are many scientific persons who seem to be quite reconciled to the crushing of humanity by a vague mechanical environment in which there are wheels within wheels. But the inner restraint of the artist is suggested in the treatment of the torment itself; which is suggested by a certain rending drag in the garments, while the limbs are limp and the head almost somnolent. She does not strive nor cry; neither is her voice heard in the streets. The artist had not to draw pain but to draw despair; and while the pain is old enough the particular despair is modern. The victim racked for a creed could at least cry "I am converted." But here even the terms of surrender are unknowable; and she can only ask "Am I civilized?"

\section{G. K. CHESTERTON.}




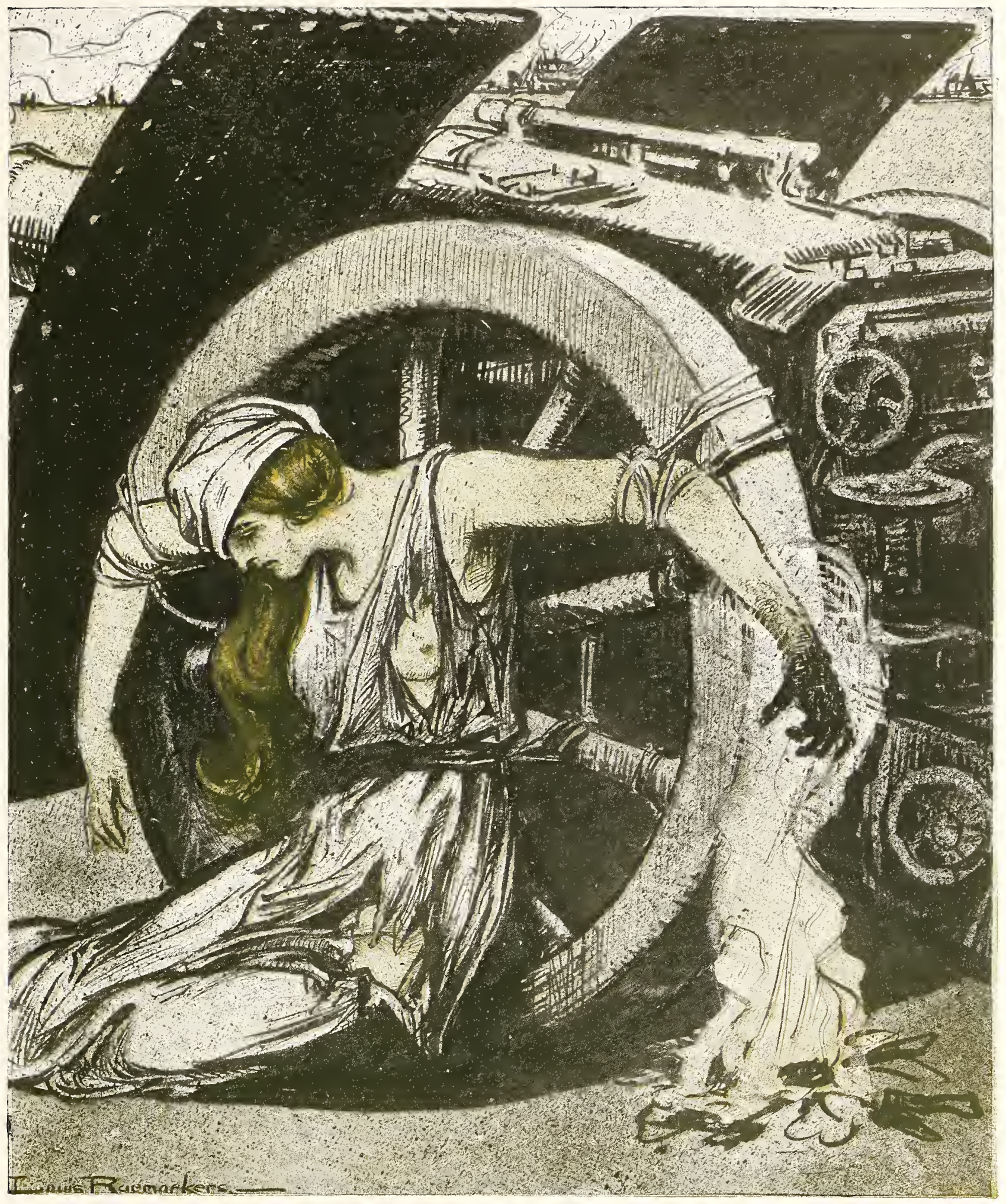

EUROPE, 1016

"Am I not yet sufficiently civilized?" 


\section{The Next to Be Kicked Out- Dumba's Master}

U

NCLE SAM is no longer the simple New England farmer of a century ago. He is rich beyond calculation. His family is more numerous than that of any European country save Russia. His interests are world-wide, his trade tremendous, his industry complex, his finance fabulous. Above all, his family is no longer of one race. The hatreds of Europe are not echoed in his house; they are shared and reverberate through his corridors. It is difficult, then, for him to take the simple views of right and wrong, of justice and humanity, that he took a century ago. He is tempted to balance a hundred sophistries against the principles of freedom and good faith that yet burn strongly within him. He is driven to temporize with the evil thing he hates, because he fears, if he does not, that his household will be split, and thus the greater evil befall him. But those that personify the evil may goad him once too often. Dumba the lesser criminal —as also the less dexterous-has betrayed himself and is expelled. When will Bernstorff's turn come? That it will come, indeed must come, is self-evident. The artist sees things too clearly as they are not to see also what they will be. He therefore skips the ignoble interlude of prevarication, quibble, and intrigue, and gives us Uncle Sam happy at last in his recovered simplicity. So we see him here, enjoying himself, as only a white man can, in a wholehearted spurning of lies, cruelty, and murder.

Note that Bernstorff-the victim of a gesture "fortunately rare amongst gentlemen" - is already in full flight through the air, while Uncle Sam's left foot has still fifteen inches to travel. The promise of an added velocity indicates that the flight of the unmasked diplomatist will be far. The sketched vista of descending steps gives us the satisfaction of knowing that the drop at the end will be deep. Every muscle of our sinewy relative is tense, limp, and projectile-the mouthpiece of Prussia goes to his inevitable end. There is no need of a sequel to show him shattered and crumpled at the bottom of the stairway.

ARTHUR POLLEN. 


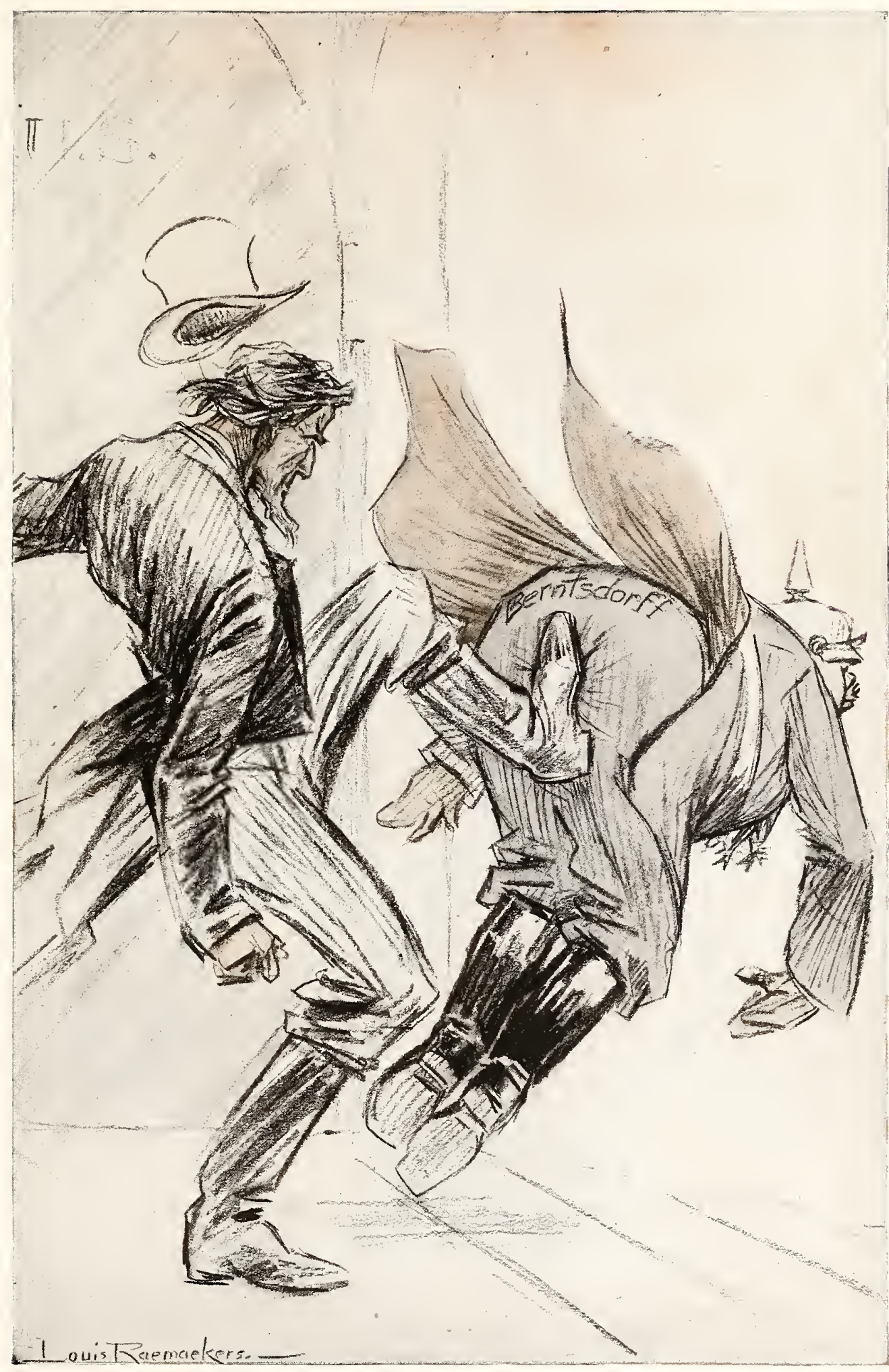

THE NEXT TO BE KICKED OUT-DUMBA'S MASTER 


\section{The Friendly Visitor}

$\mathrm{R}$ AEMAEKERS is never false, and he never works for effect alone. That is what makes him so terrible to the people he criticises, and so effective.

When he wants to depict the sturdy Dutch soul he draws a sturdy Dutch Body - ready to defend her home. No flags, no highfalutin, no symbolical figure posed for show; just cleanliness, determination, and good sense facing bestiality and oppression.

The figure that stands for the Freedom of the Home opposed to the figure that stands for the Freedom of the Seas.

Many an Englishman might take this picture to heart.

H. DE VERE STACPOOLE. 


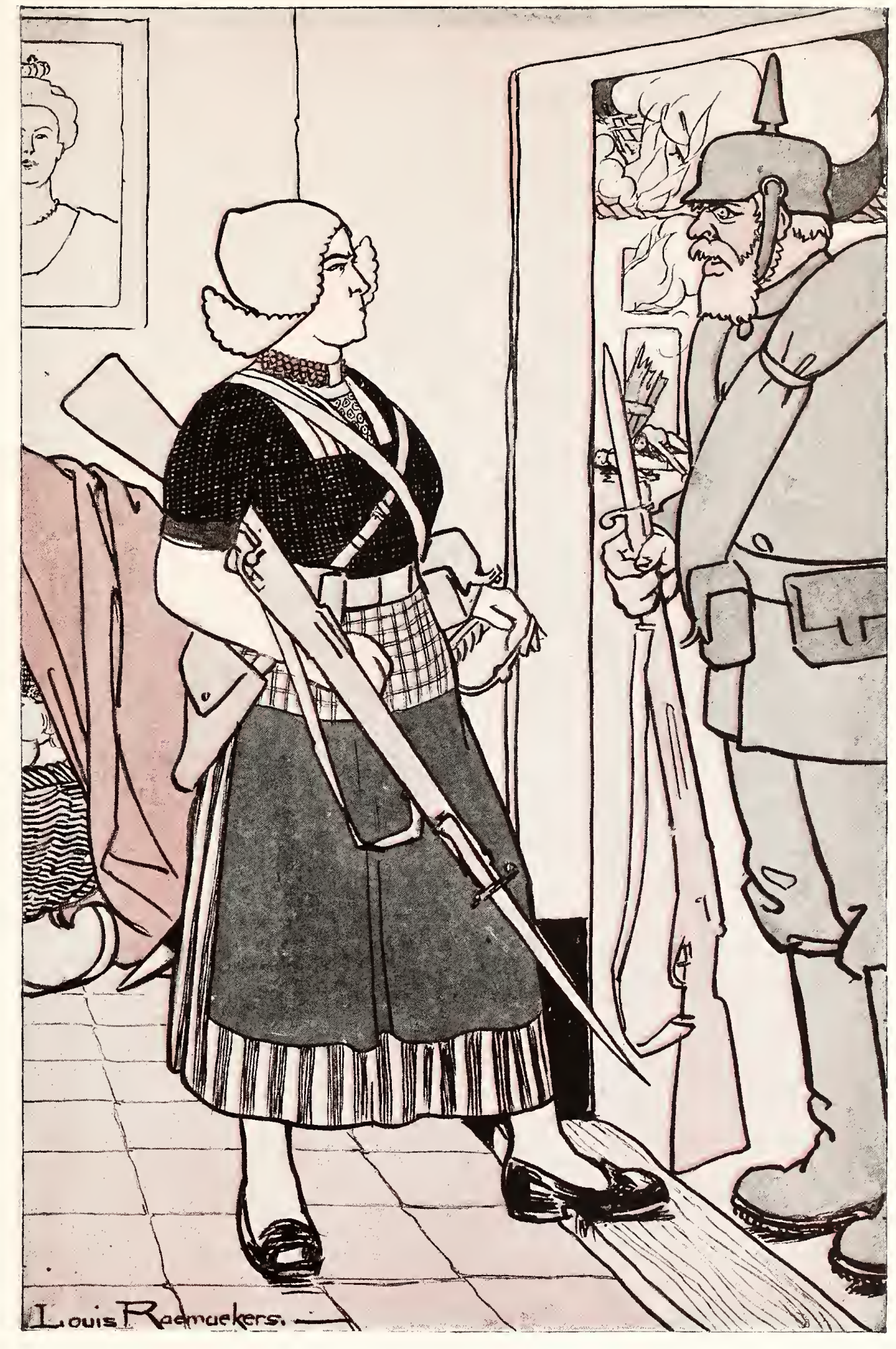

THE FRIENDLY VISITOR

The German : "I come as a friend."

Holland: "Oh, yes. I've heard that from my Belgian sister." 


\section{"To Your Health, Civilization!"}

$\mathrm{T}$ HIS terrible cartoon points its own lesson so forcibly that its effect is more likely to be weakened than strengthened by any verbal comment. Death quaffs a goblet of human blood to the health of Civilization. Death has never enjoyed such a carnival of slaughter before, and it is Civilization that has made the holocaust possible. The comparatively simple methods of killing employed by barbarians could not have destroyed so many lives; nor could barbarian states have raised such huge armies. The artist makes us feel that such a war as this is an act of moral madness, a disgrace to our common humanity. It is true that some of the nations engaged are guiltless, and others almost guiltless; but there is a solidarity of European civilization which obliges us all to share the shame and sorrow of this monstrous crime. Universal war is the reductio ad absurdum of false political theories and false moral ideals; and the reductio ad absurdum is the chief argument which Providence uses with mankind. Perhaps it is the only argument which mankind in the mass can understand.

THE DEAN OF ST. PAUL'S. 


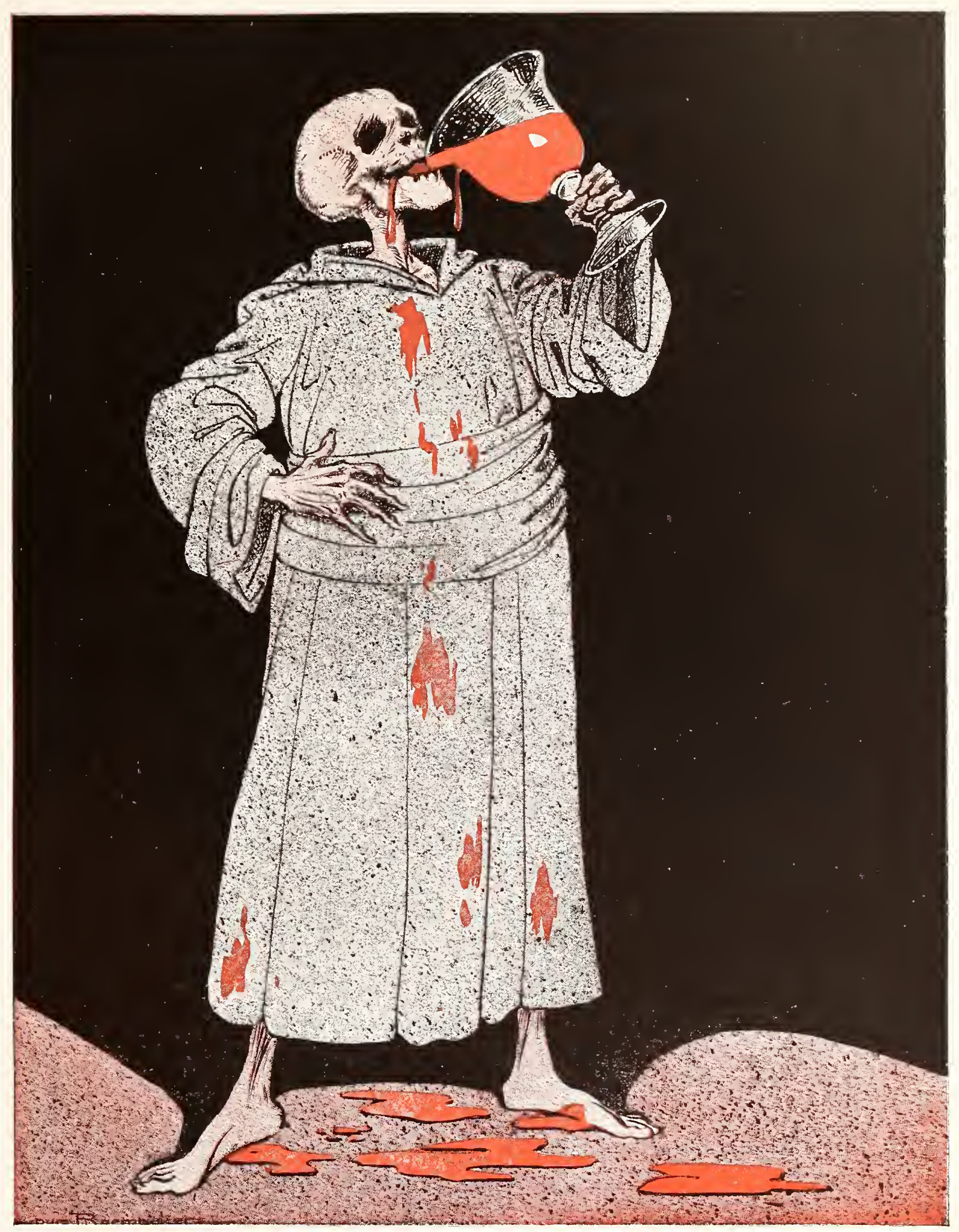

"TO YOUR HEALTH, CIVILIZATION!" 


\section{Fox Tirpitz Preaching to the Geese}

HERE is nothing more pathetic in some ways to-day than the position of the small neutral countries in Europe, and especially those which directly adjoin Germany. And there is nothing more galling than the inability of the Allies to give them any help. For the hour they are absolutely at the mercy of Germany, or would be, if she had any, and they know it. They are certainly liable and exposed to all her flouts and cuffs and to any displays of bad temper or bullying or terrorism it may please her to exercise. And none perhaps is worse off in this respect than Holland. It suits Germany to be fairly civil to Switzerland, who could give her a good deal of trouble by joining France and Italy; and no doubt it suits her too to some extent to consider Denmark, for Denmark commands the entrance to the Baltic; and, further, Germany does not wish to bring all Scandinavia down upon herself just at present. That can wait; but Holland is in the worst plight of all. She has the terrible spectacle of Belgium, ruined and ravaged, just on the other side of the way. And she has a very considerable and valuable mercantile marine.

The great and good Germany cannot be troubled to distinguish between Dutch and other boats, and if occasionally a Dutch ship is captured or sent to the bottom, it is a useful reminder of what she might do to her "poor relation" if she really let herself go. Fighting for the freedom of the seas! Holland has fought for them herself. Holland has a great naval tradition. She knows quite well what England has been and is. She knows too, and can see, how her sons and brothers in South Africa were treated by the British in England's last war, and how they regard England and Germany now.

Raemaekers' cartoon is very skilful. If we had not seen it done, we should not have believed it possible to produce at once so clever a likeness of Von Tirpitz and so excellent an old fox. But the goose is by no means a foolish bird, though its wisdom may sometimes be shown in knowing its own weakness. It was they, and not the watchdogs, that saved the Capitol. In old days it was the custom to call the Germans the "High Dutch" and the inhabitants of Holland the "Low Dutch." It was a geographical distinction. The contrast in moral elevation is the other way.

HERBERT WARREN. 


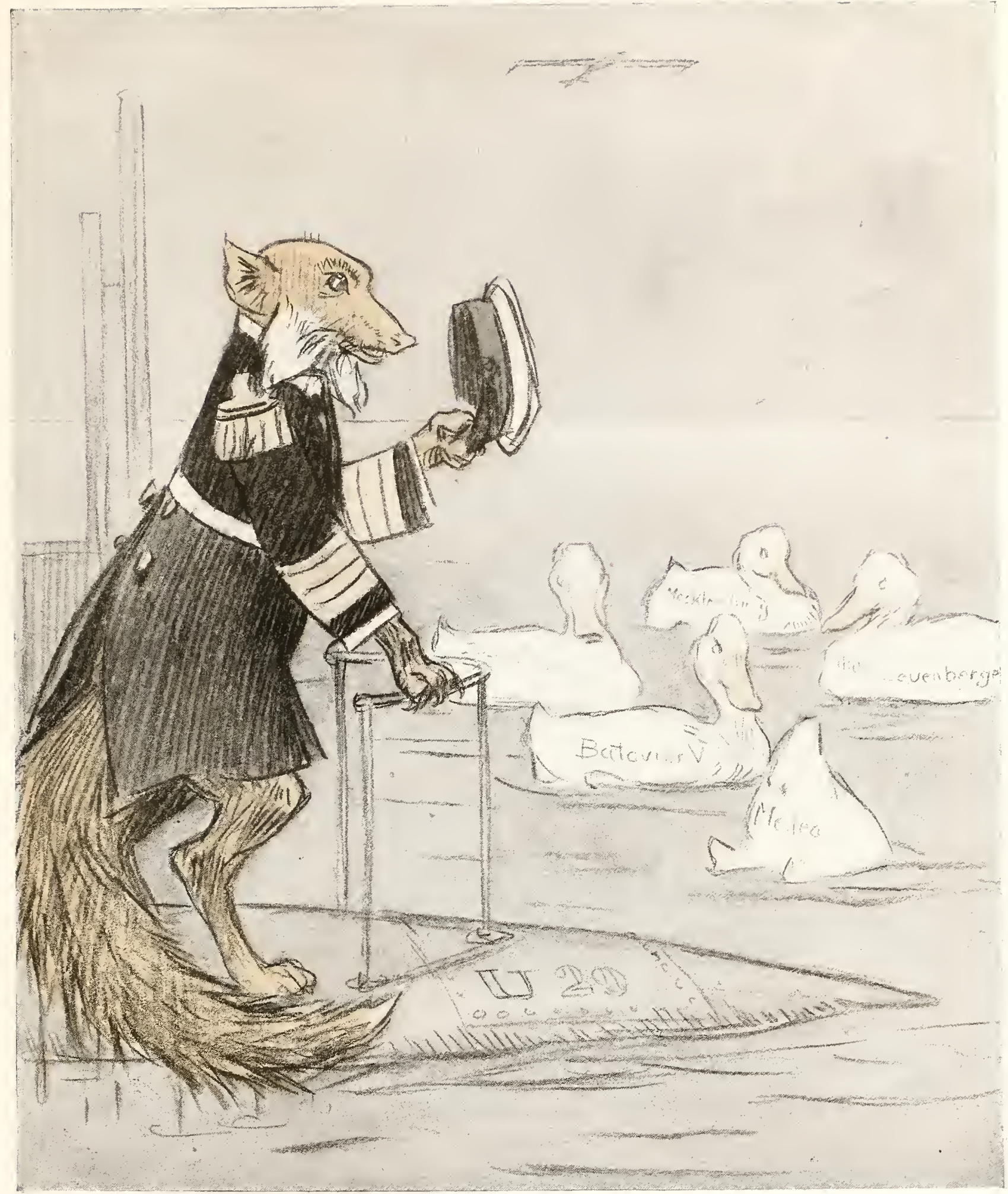

FOX TIRPITZ PREACHING TO THE GEESE

"You see, my little Dutch geese, I am fighting for the freedom of the seas." (The Germans illegally captured several Dutch ships.) 


\title{
The Prisoners
}

\begin{abstract}
VILE feature of German "frightfulness" is this: that she A mixes poison with her prisoners' rations. Not content with 1 starving their bodies, she hides truth from them and floods their minds with lies. Those in command-officers, educated men, claiming the service of their soldiers and civil guard and the respect of their nation-deliberately hash a daily meal of falsehood and serve up German victories and triumphs on land and sea as sauce to the starvation diet of their defenceless captives.
\end{abstract}

In the earlier months of the war, while yet the spiritual slough into which Germany had sunk was unguessed, and the mixture of child and devil exemplified by "frightfulness" continued unfathomed, these daily lies undoubtedly answered their cowardly purpose, cast down the spirit of thousands, and added another pang to their captivity. But our armies know better now, and those diminishing numbers likely to be taken prisoner in the future see the end more clearly than the foe can. Lies will be met with laughter henceforth, for our enemies have put themselves beyond the pale. They may starve and insult our bodies; but their power to poison our brains has passed from them forever. We know them at last. They have spun a web of barbed villainy between their souls and ours; and the evil committed for one foul purpose alone-to terrify free men and break the spirit of the sons of liberty-has produced results far different and created a situation more terrible for them than for their outraged enemies.

For in this matter of misrepresentation and lying, born of Prussia and by her spoon-fed pack of martinets, professors, and Churchmen, mingled with Germany's daily bread for a generation, it is she and not we who will reap the whirlwind of that sowing; it is she and nol we who must soon pant and tear the breast in the pangs of the poison.

Between the mad and the sane there can be only one victor; and when the time comes, may Germany's robe of repentance be a straitwaistcoat of the Allies' choosing. For she has drunk deep of the poison, and those who anticipate a speedy cure will be as mad as she. When the escaped tigress is back in her cage, men look to the bars, for none wants a second mauling.

EDEN PHILLPOTTS. 


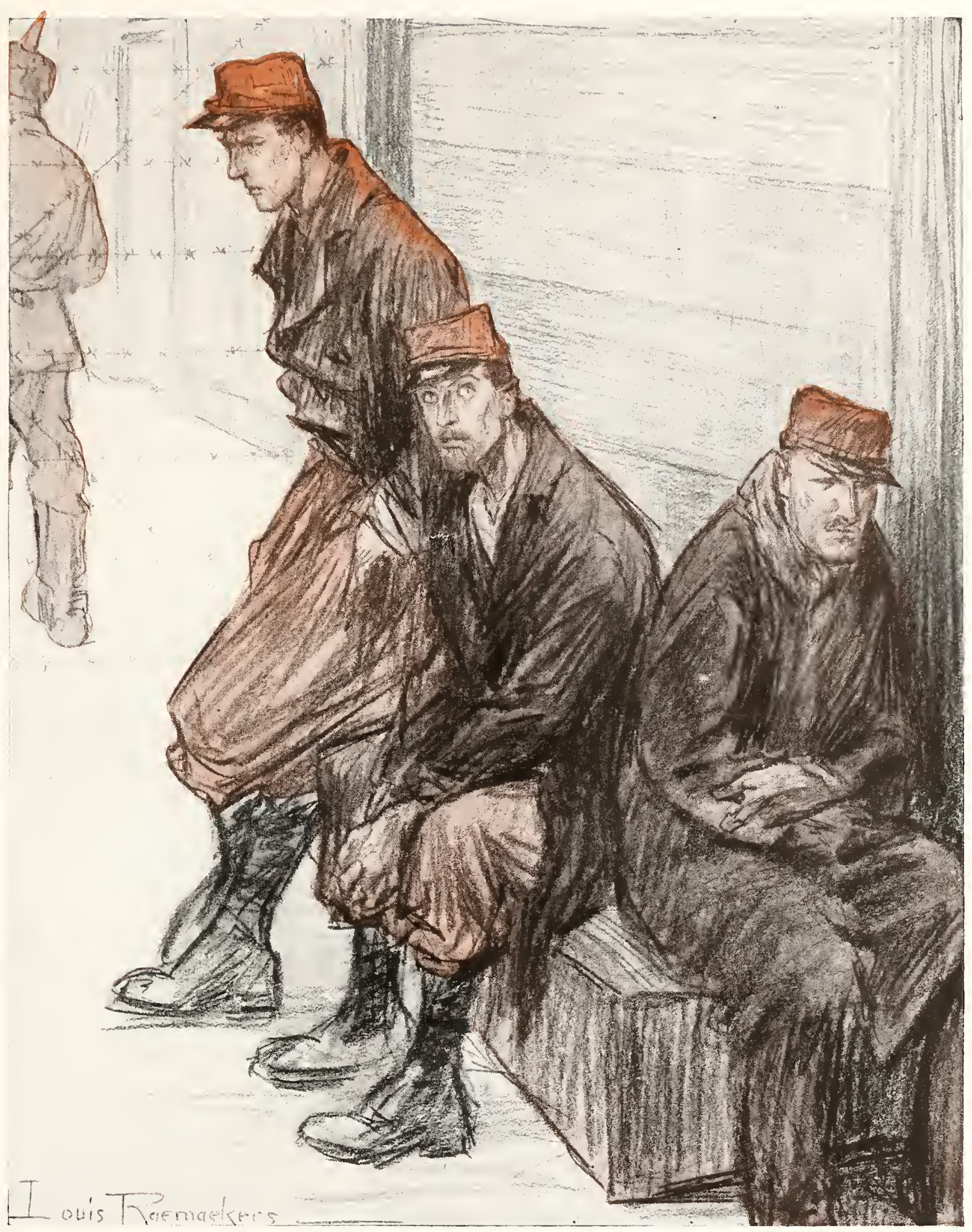

THE PRISONERS 


\section{It's Unbelievable}

I AM not sure that in this cartoon of Raemaekers the most pleasing detail is not the servant's right eye. You will observe in that servant's right eye an expression familiar in those who overhear this sort of comment upon the peculiar bestialities of the Prussian in Belgium and Poland, this extenuation of his baseness. When the war was young the opportunity for giving that glance was commoner than it is now. There were many even in a belligerent country who would tell you in superior fashion how foolishly exaggerated were the so-called "atrocities." The greater number of such men (and women) talked of "two Germanies"- - one the nice Germany they knew and loved so well, and the other apparently nasty Germany which raped, burned, stole, broke faith, tortured, and the rest. Their number has diminished. But there is a little lingering trace of the sort of thing still to be discovered: men and women who hope against hope that the Prussian will really prove good at heart after all. And it is usually just after some expression of the kind that the most appalling news arrives with a terrible irony to punctuate their folly. It reminds one a little of the man in the story who was sure that he could tame a wild cat, and was in the act of recording its virtues when it flew in his face. To an impartial observer who cared nothing for our sufferings or the enemy's vices, there would be something enormously comic in the vision of these few remaining (for there are still some few remaining) that approach the wild beast with soothing words and receive as their only reward a very large bomb through the roof of their house, or the news that some one dear to them has been murdered on the high seas. But to those actively suffering in the struggle the comic element is difficult to seize, and it is replaced by indignation. This fantastic misconception of the thing that is being fought is bound to be burned right out by the realities of the enemy acts in belligerent countries. It will be similarly destroyed-and that in no very great space of timein all neutral countries as well. Prussia will have it so. She is allowing no moral defence to remain for her future. It is almost as though the men now directing her affairs lent ear carefully to every word spoken in praise of them abroad, and met it at once by the tremendous denial of example. It is almost as though the Prussian felt it a sort of personal insult to receive the praise of dupes and fools, and perhaps it is.

HILAIRE BELLOC. 


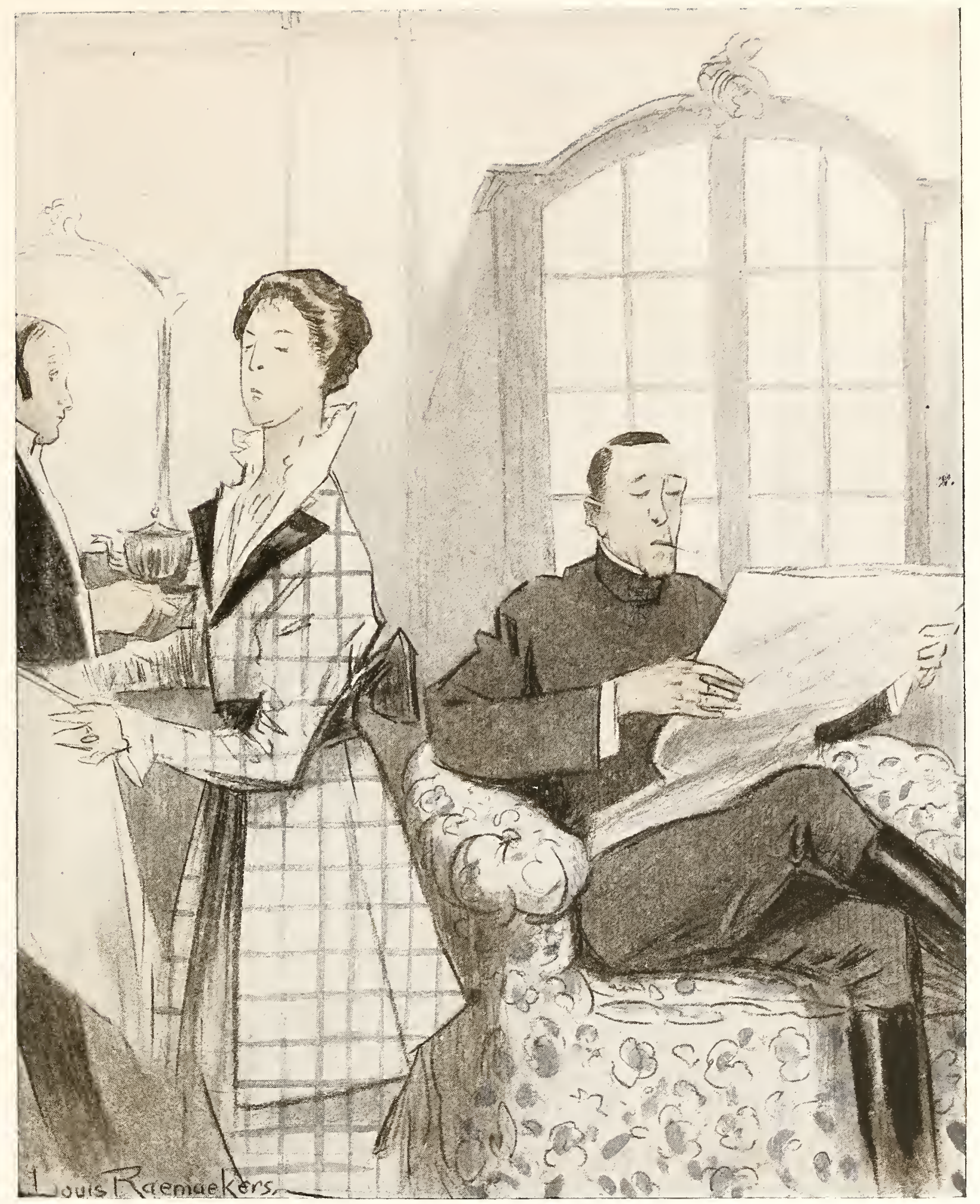

IT'S UNBELIEVABLE

Dutch Officer: "How can they have soiled their hands by such atrocities?" SHE: "Can they have done it, my dear? German officers are so nice." 


\section{Kreuzland, Kreuzland Über Alles}

$\mathrm{T}$

HIS war has produced examples of every kind of misery which human beings can inflict upon each other, except one. Europe has mercifully been spared long sieges of populous towns, ending in the surrender of the starving population. But many towns and villages have been burnt; and masses of refugees have fled before the invader, knowing too well the brutal treatment which they had to expect if they remained. Very many of the unhappy Belgians have taken refuge in Holland; a considerable number have found an asylum in this country. They are homeless and ruined; if the war were to end to-morrow, many of them would not know where to go or how to live. Families have been broken up; husbands and wives, parents and children, are ignorant of each other's fate. In this picture we see a crowd of children, herded together like a flock of sheep, with nobody to take care of them. Their via dolorosa is marked by long rows of crosses on either side, emblems of suffering, death, and sacrifice. In the distance rise the smoke and flames from one of the innumerable incendiary fires which the Germans, like the cruel banditti of the Middle Ages, have kindled wherever they go.

THE DEAN OF ST. PAUL'S. 


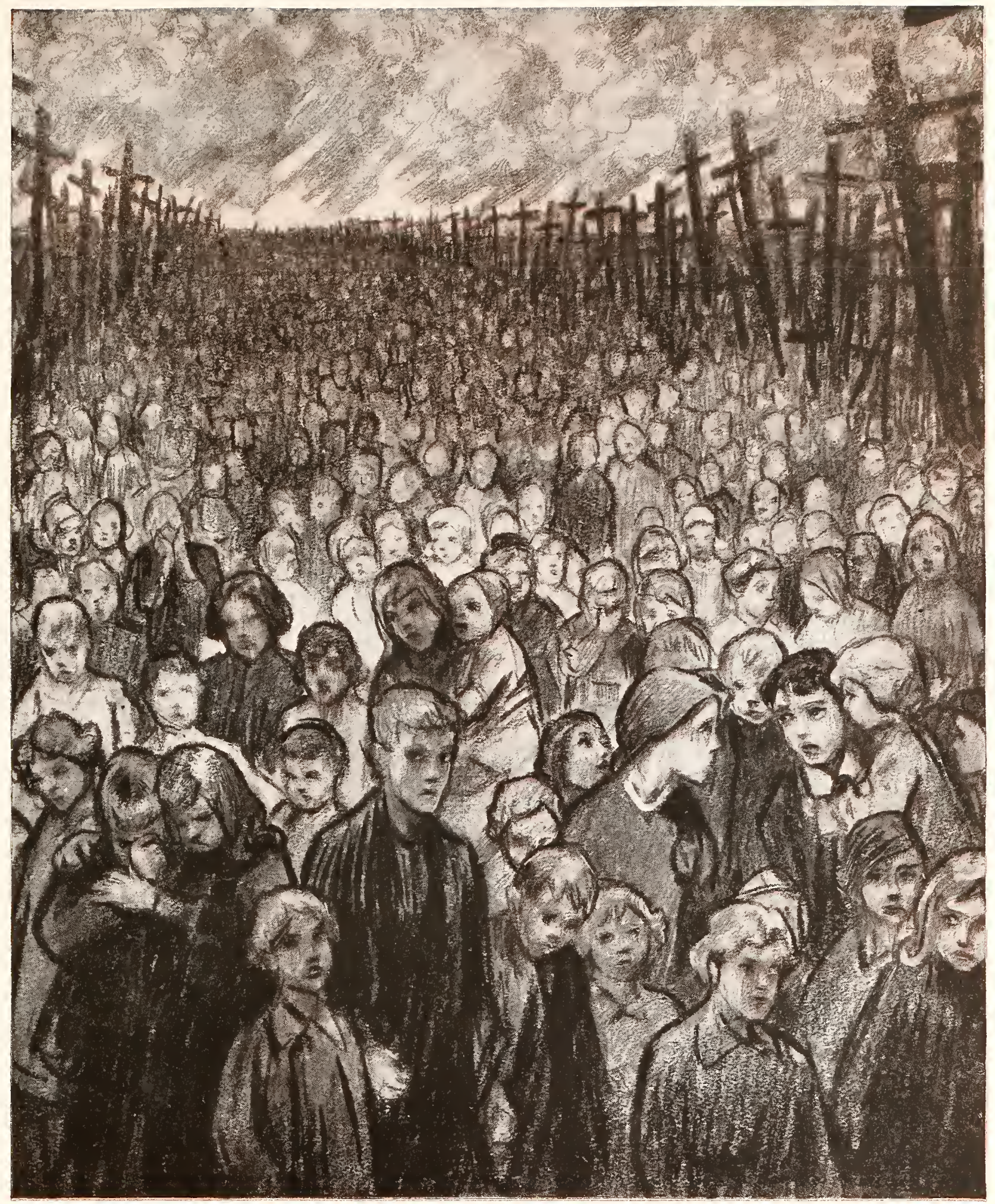

KREUZLAND, KREUZLAND ÜBER ALLES

Belgium, 1914: "Where are our fathers?" 


\section{The Ex-convict}

$\mathrm{P}^{\mathrm{n}}$ RUSSIA in every war has betrayed that peculiar mark of barbarism consisting in using the intellectual weapons of a superior, but not knowing how to use them. It is still a matter of mystery to the directing Prussian mind why the sinking of the Lusitania should have shocked the world. A submarine cannol take a prize into port. The Lusitania happened to be importing goods available in war, therefore the Lusilania must be sunk. All the penumbræ of further consideration which the civilized man weighs escape this sort of logic. Similarly, the Prussian argues, if an armed man is prepared to surrender, convention decrees that his life should be spared. Therefore, if an armed man be just fresh from the murder of a number of children, he has but to cry "Kamerad" to be perfectly safe. And Prussia foams at the mouth with indignation whenever this strict rule of conduct is forgotten in the heat of the moment. The use of poison in the field which Prussia for the first time employed (and reluctantly compelled her civilized opponents to reply to) is in the same boat. A shell bursts because solid explosive becomes gaseous. To use shell which in bursting wounds and kills men is to use gas in war; therefore if one uses gas in the other form of poison, disabling one's opponent with agony, it is all one. Precisely the same barbaric use of logicwhich reminds one of the antics of an animal imitating human gestures -will later apply to the poisoning of water supplies, or the spreading of an epidemic. It is soldierly and excites no contempt or indignation to strike at your enemy with a sword or shoot a pellet of lead at him in such a fashion that he dies. What is all this foolish pother about killing him with bacilli in his cisterns or with a drop of poison in his tea? Men in war have burned groups of houses with the torch in anger or for revenge. Why distinguish between that and the methodical sprinkling of petroleum from a hose by one gang and the equally methodical burning of the whole town house by house with little capsules of prepared incendiary stuff? The rule always applies-but only against the opponent: never to one's self. From that attitude of mind the Prussian will never emerge. We shall, please God, see that mood in all its beauty in later stages of the war, when the coercion of the Prussian upon his own soil leads to acts indefensible by Prussian logic. We have already had a taste of this sort of reasoning when the royalties fled from Karlsruhe and when the murderers upon the sinking Zeppelin received the reward due to men who boast that they will not keep faith.

HILAIRE BELLOC. 


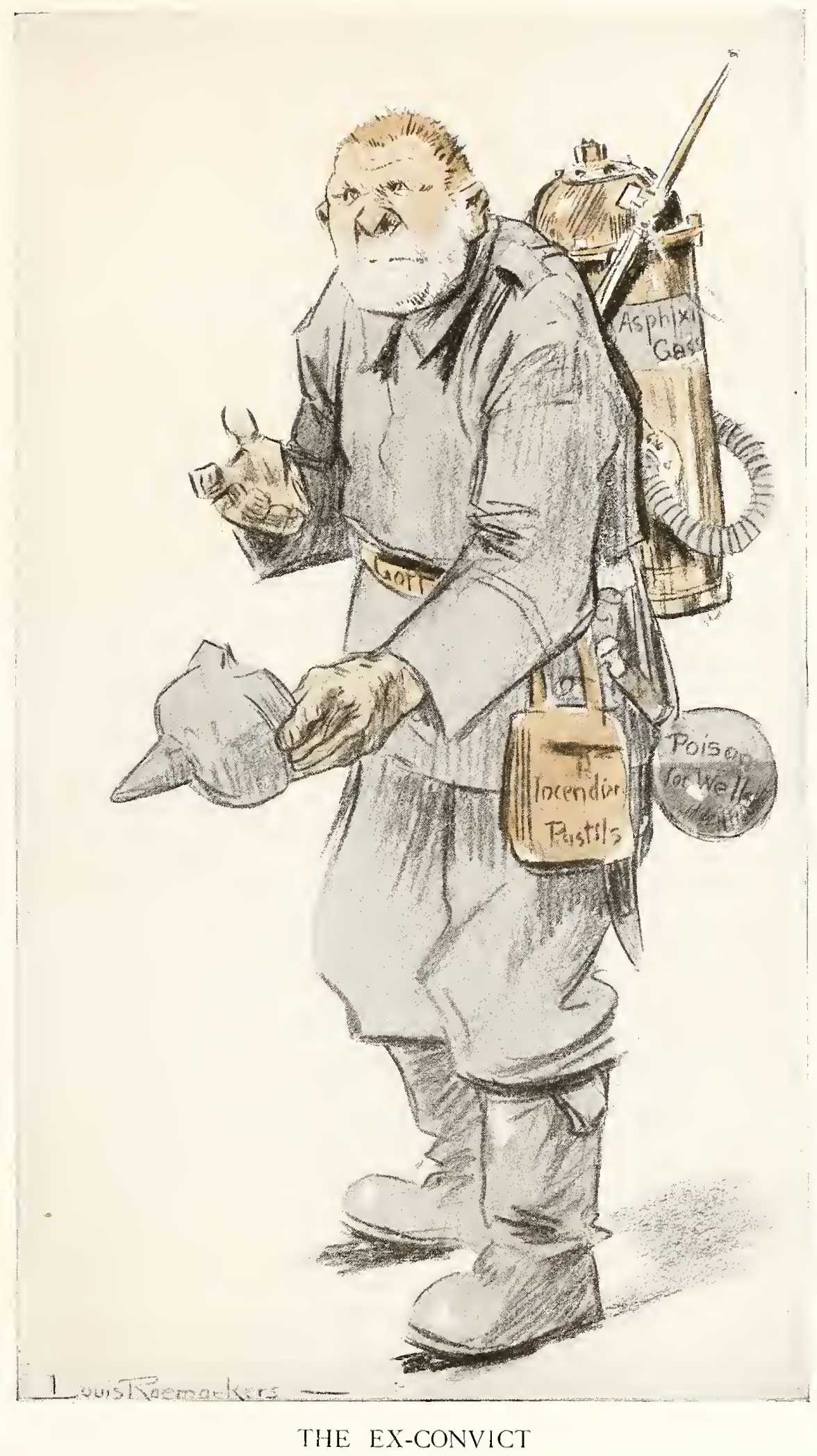

" I was a 'lifer,' but they found I had many abilities for bringing civilization amongst our neighbours, so now I am a soldier." 


\section{Miss Cavell}

$\mathrm{M}$

OST of the English caricaturists are much too complimentary to the German Emperor. They draw his moustaches, but not his face. Now his moustaches are exactly what he, or the whole Prussian school he represents, particularly wishes us to look at. They give him the fierce air of a fighting cock; and however little we may like fierceness, there will always be a certain residual respect for fighting, even in a cock. Now the Junker moustache is a fake; almost as much so as if it were stuck on with gum. It is, as Mr. Belloc has remarked, curled in a machine all night lest it should hang down. Raemaekers, in the sketch which shows the Kaiser as waiting for Nurse Cavell's death to say, "Now you can bring me the American protest," has gone behind the moustache to the face, and behind the face to the type and the spirit. The Emperor is not commanding in a lordly voice from a throne, but with a leer and behind a curtain. In the few lines of the lean, unnatural face is written the real history of the Hohenzollerns, the kind of history not of ten touched on in our comfortable English humour, but common to the realism of Continental art: the madness of Frederick William, the perversion of Frederick the Great, the hint, mingled with subtler talents, of the mere idiocy that seems to have flowered again in the last heir of that inhuman house. The Hohenzollerns have varied from generation to generation in many things and like many families; some of them have been tyrants, some of them geniuses, some of them merely boobies; but they have shared in something more than that hereditary policy which has been the poison in Christendom for two hundred years. There is a ghost who inhabits these perishing tenements, and in such a picture as this of Raemaekers men can see it looking out of the eyes. And it is neither the spirit of a tyrant nor of a booby; but the spirit of a sly invalid.

\section{G. K. CHESTERTON.}




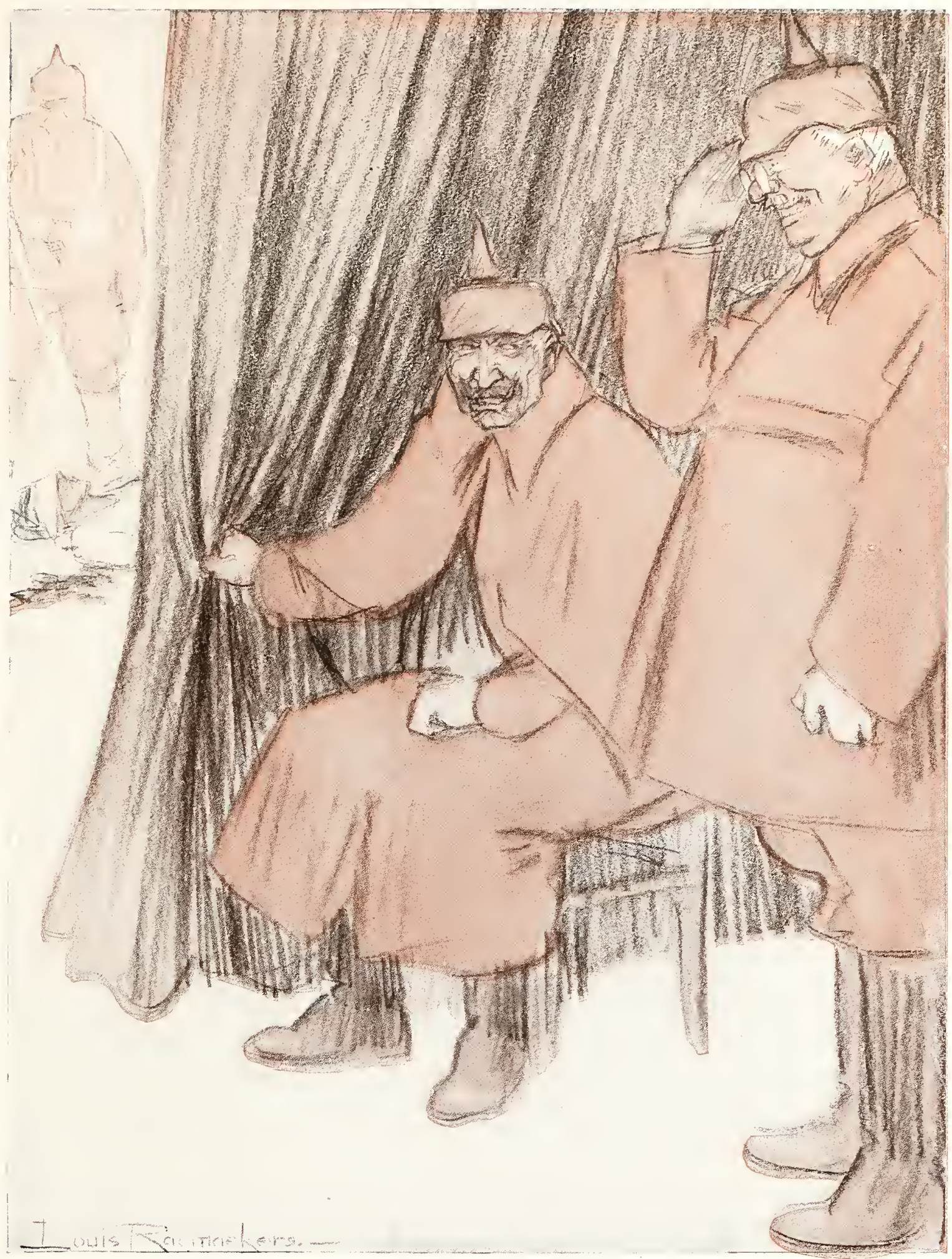

MISS CAVELL

William: "Now you can bring me the American protest." 


\section{The Hostages}

$A^{\prime}$

, boy-you may well ask.

And the world asks also, and in due time will exact an answer-to

the last drop of innocent blood.

What have you done?

You have fallen into the hands of the most scientifically organized barbarism the world has ever seen, or, please God, ever will see-to whom, of deliberate choice, such words as truth, honour, mercy, justice, have become dead letters, by reason of the pernicious doctrines on which the race has been nourished-by which its very soul has been poisoned.

Dead letters? - worn-out rags, the very virtues they once represented, even in Germany, long since flung to the dust-heaps of the past in the soulless scramble for power and a place in the sun which no one denied her.

Deliberately, and of malice prepense, the military caste of Prussia has taught, and the unhappy common-folk have accepted, that as a nation they are past all that kind of thing. There is only one right in the world-the might of the strongest. The weak to the wall! Make way for the Hun, whose god is power, and his highpriests the Kaiser and the Krupps.

And so, every nation, even the smallest, on whom the eye of the Minotaur has settled in baleful desire, has said, "Better to die fighting than fall into the hands of the devil!" And they have fought-valiantly, and saved their souls alive, though their bodies may have been crushed out of existence by overwhelming odds. As nations, however, they shall rise again, and with honour, when their treacherous torturers have been crushed in their turn.

And, wherever the evil tide has welled over a land, indemnities, incredible and unreasonable, have been exacted, and hostages for their payment, and for good behaviour under the yoke meanwhile, have been taken.

Woe unto such! In many cases they have simply been shot in cold bloodmurdered as brazenly as by any Jack-the-Ripper. Murder, too, of the most despicable-murder for gain-the gain that should accrue through the brutal terrorism of the act and its effect on the rest.

And, if deemed advisable to gloss the crime with some thin veneer of imitation justice for the-unsuccessful--hoodwinking of a shocked and astounded world, what easier than an unseen shot in some obscure corner from a German rifle? Then-"Death to the hostages! - destruction to the village! - a fine of $\mathfrak{1 0 0 , 0 0 0}$ on the town!"

Those provocative shots from German rifles have surely been the most profitably engineered basenesses in the whole war. They have justified-but in German eyes only-every committable crime, and they cost nothing-except the souls of their perpetrators.

"It's your money we want-and your land-and your property-and, if necessary, your lives! You are weak-we are strong-and so-_-!' That is the simple Credo of the Hun.

But for all these things there shall come a day of reckoning and the account will be a heavy one.

May it be exacted to the full-from the rightful debtors!

"What have you done?" You have at all events put the rope round the necks of your murderers, and the whole world's hands are at the other end of it.

JOHN OXENHAM. 


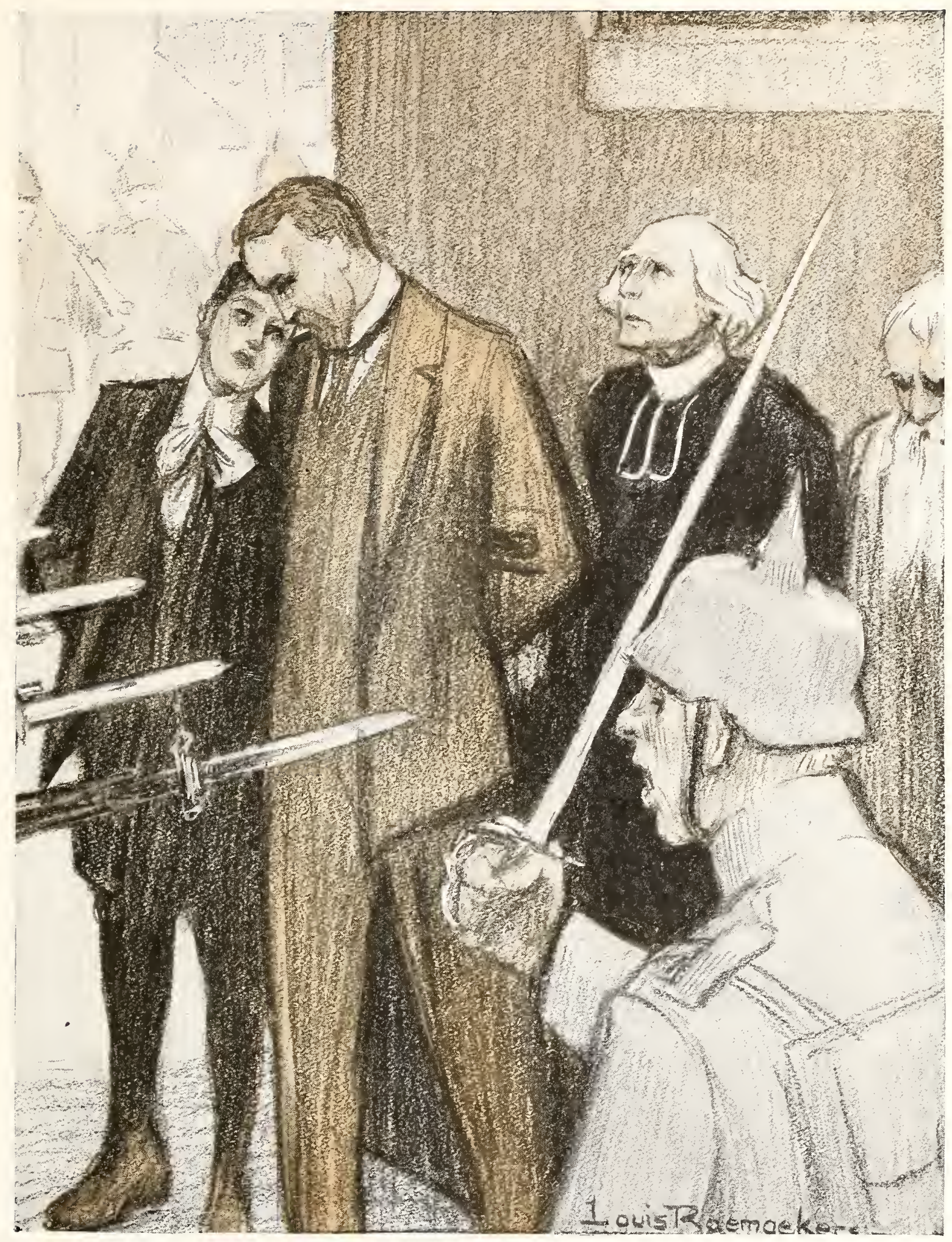

THE HOSTAGES

"Father, what have we done?" 


\section{King Albert's Answer to the Pope}

T

HE war has been singularly barren of heroic figures, perhaps because the magnitude of the events has called forth such a multitude of individually heroic acts that no one can be placed before the rest; yet, when this greatest phase of history comes to be written down with historic perspective, one figure - that of King Albert of Belgium-will stand as that of a twentieth-century Bayard, a great knight without fear and without reproach.

Action on such far-flung lines as those of the European conflict has called for no great leaders in the sense in which that phrase has applied to previous wars; no Napoleon has arisen, though William Hohenzollern has aspired to Napoleonic dignity; war has become more mechanical, more a matter of mathematics-and the barbarians of Germany have made it more horrible. But, as if to accentuate German brutality and crime, this figure of King Albert stands emblematic of the virtues in which civilization is rooted; to the broken word of Germany it opposes untarnished honour; to the treacherous spirit of Germany it opposes inviolable truth; to the relentless selfishness of Germany it opposes the vicarious sacrifice of self, of a whole country and nation for the sake of a principle. And, in later days, men will remember how this truly great king held steadfastly to the litle portion of his kingdom that the invasion left him; how he remained to inspirit his men by noble example, stubbornly rejecting peace without honour, and holding, when all else was wrecked, to the remnants of that army which saved Europe in the gateway of Liége. Amid violation, desecration, and destruction, Albert of Belgium has won imperishable fame.

E. CHARLES VIVIAN. 


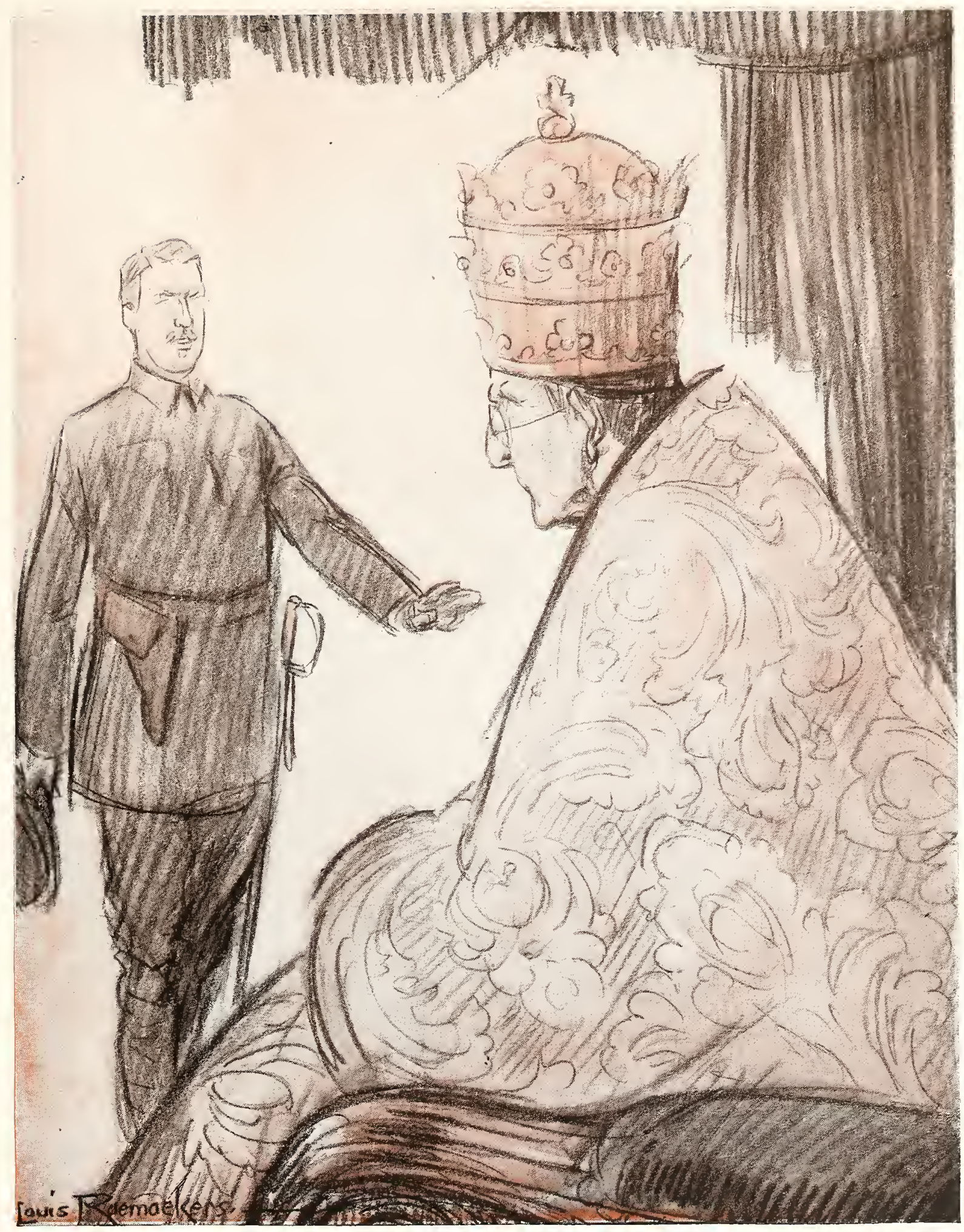

KING ALBERT'S ANSWER TO THE POPE

"With him who broke his word, devastated my country, burned my villages, destroyed my towns, desecrated my churches, and murdered my people, I will not make peace before he is expelled from my country and punished for his crimes." 


\section{The Gas Fiend}

$\mathrm{T}$

HERE is an order of minds that intuitively distrusts Science, detracts from the force of her achievements, and contends that devotion to machinery ends by making men machines. Many who argue thus have fastened on Germany's new war inventions as proof that Science makes for materialism and opposes the higher values of humanity and culture.

This is special pleading, for against the destructive forces discovered and liberated by German chemists in this war, one has only to consider the vast amelioration of human life for which modern science has to be thanked. Because art has been created to evil purpose, shall we condemn pictures or statues? Because the Germans have employed gas poisons in warfare, are we to condemn the incalculable gifts of organic chemistry?

Look at the eye of Louis Raemaekers' snake. That is the answer. It is the force behind this application of it that has brought German Science to shame. A precious branch of human knowledge has been prostituted by lust of blood and greed of gain until Science, in common with all learning, comes simply to be regarded by the masters of Germany as one more weapon in the armoury, one more power to help win "The Day." Every culture is treated in their alembic for the same purpose.

We may picture the series of experiments that went to perfection of their poison gas; we may see their Higher Command watching the death of guinea-pig, rabbit, and ape with increasing excitement and enthusiasm as the hideous effects of their discovery became apparent. Be sure an iron cross quickly hung over the iron heart that conceived and developed this filthy arm; for does it not offer the essencequintessence of all "frightfulness?" Does it not challenge every human nervecentre by its horror? Does it not, once proclaimed, by anticipation awake those very emotions of dread and dismay that make the stroke more fatal when it falls?

These people pictured their snake paralyzing the enemy into frozen impotence; the floundering Prussian psychology that cuts blocks with a razor and regards German mind as the measure of all mind, anticipated that poison gas would appeal to British and French as it has appealed to them. But it was not so. Their foresight gave them an initial success in the field; it slew a handful of men with additions of unspeakable agony--and rekindled the execration and contempt of Civilization.

As an arm, poison gas cannot be considered conspicuously successful, since it is easily encountered; but for the Allies it had some value, since it weighted appreciably the scale against Germany in neutral minds and added to the universal loathing astir at the heart of the world. Only fear now holds any kingdom neutral: there is not an impartial nation left on earth.

EDEN PHILLPOTTS. 


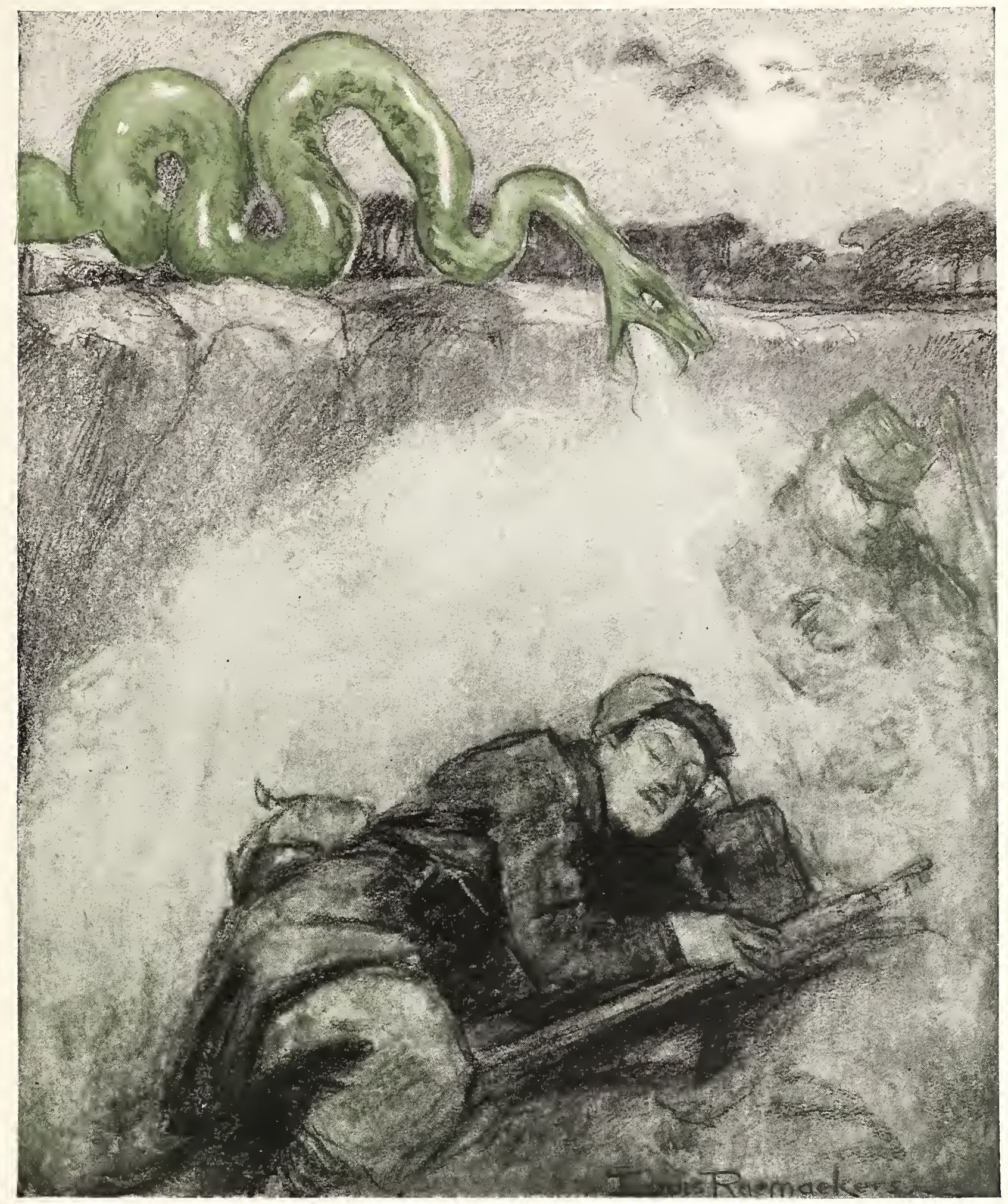

THE GAS FIEND 


\title{
The German Tango
}

\begin{abstract}
$\Lambda$ BLOND woman, wearing the Imperial crown and with her hair braided in pigtails like a German backfisch, is whirling in the tango with a skeleton partner. Her face is livid with terror and fatigue, her limbs are drooping, but she is held by inexorable bony claws. On the feet of the skeleton are dancing pumps, a touch which adds to the grimness. This ghoulish dance does not lack its element of ghastly ceremonial.
\end{abstract}

The Dance of Death has long been the theme of the moralist in art, from Orcagna's fresco on the walls of the Campo Santo at Pisa to Holbein's great woodcuts and our own Rowlandson. In Germany especially have these macabre imaginings flourished. The phantasmagoria of decay has haunted German art, as it haunted Poe, from Dürer to Boecklin. But the mediæval Dance of Death was stately allegory, showing the pageant of life brooded over by the shadow of mortality. In M. Raemaekers' cartoon there is no dignity, no lofty resignation. He shows Death summoned in a mad caprice and kept as companion till the revel becomes a whirling horror.

It is the profoundest symbol of the war. In a hot fit of racial pride Death has been welcomed as an ally. And the dance on which Germany enters is no stately minuet with something of tragic dignity in it. It is a common modern vulgar shuffe, a thing of ugly gestures and violent motions, the true sport of degenerates. Once begun there is no halting. From East to West and from West to East the dancers move. There is no rest, for Death is a pitiless comrade. From such a partner, lightly and arrogantly summoned, there can be no parting. The traveller seeks a goal, but the dancers move blindly and aimlessly among the points of the compass. Death, when called to the dance, claims eternal possession.

JOHN BUCHAN. 


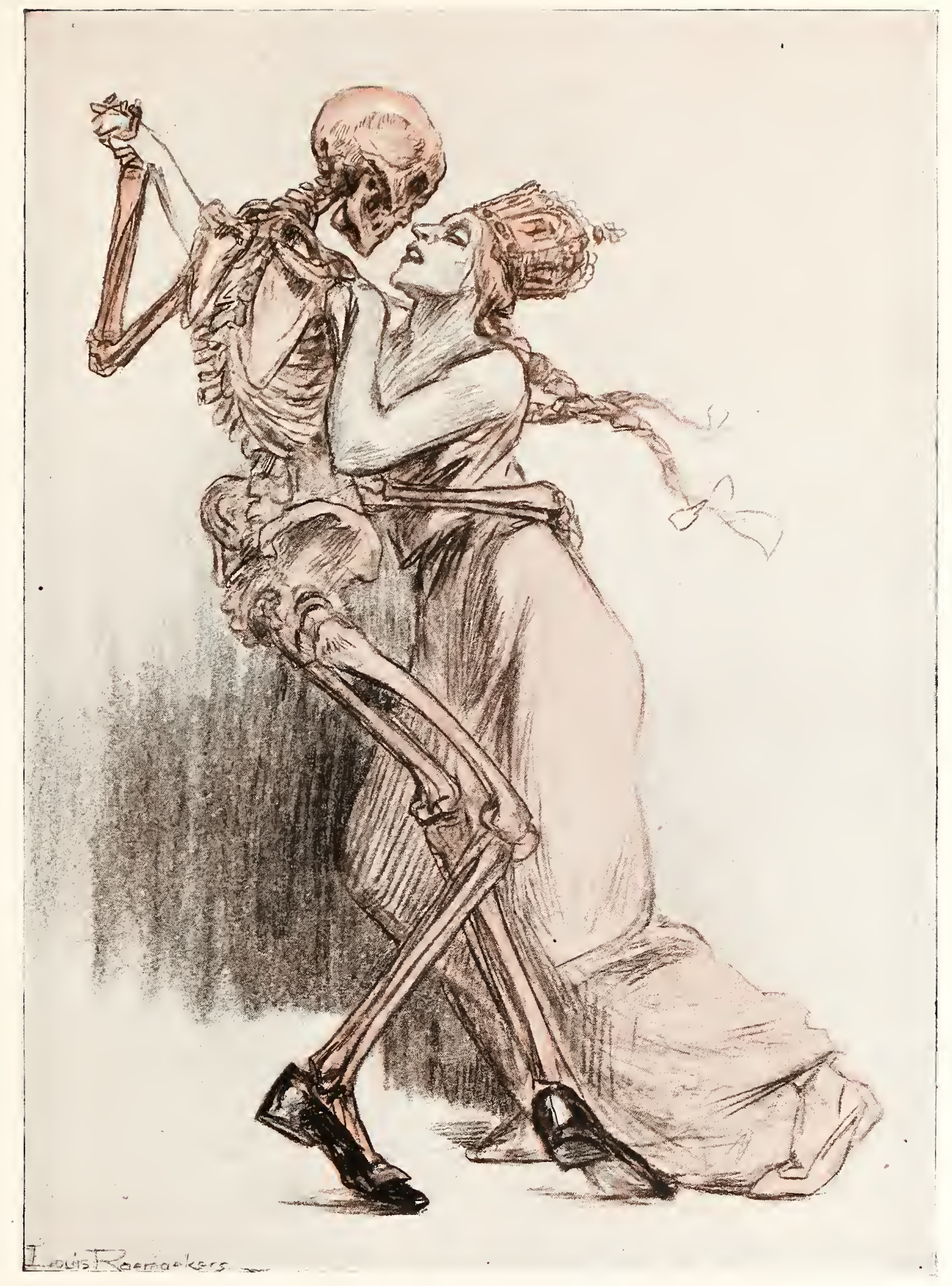

THE GERMAN TANGO

"From East to West and West to East I dance with thee!" 


\section{The Zeppelin Triumph}

W

HEN the future historian gives to another age his account of all that is included in German "frightfulness," there is no feature upon which he will dilate more emphatically than the extraordinary use made by the enemy of their Zeppelin fleet. In the experience we have gained in the last few months we discover that the Zeppelins are not employed - or, at all events, not mainly employed-for military purposes, but in order to shake the nerves of the non-combatant population. The history of the last few Zeppelin raids in England is quite sufficient testimony to this fact. London is bombarded, although it is an open city, and a large amount of damage is done to buildings wholly unconnected with the purposes of the war. The persons who are killed are not soldiers, they are civilians; the buildings destroyed are not munition works, but dwellinghouses, and some of the points of attack are theatres.

The same thing has happened in the provinces. In the last raid over the Midlands railway stations were destroyed, some breweries were injured, but, with exceedingly few exceptions, munition works and factories for the production of arms were untouched. Here again the victims are not either soldiers or sailors, or even workmen employed in turning out instruments of war, but peaceable citizens and a large proportion of women and children.

Some such act of brutality is illustrated in the accompanying cartoon. A private house has been attacked, the mother has been killed, the father and child are left desolate. The little daughter at her father's knee, who cannot understand why guiltless people should suffer, asks the importunate question whether her mother had done anything wrong to deserve so terrible a fate. To the childish mind it seems incomprehensible that aimless and indiscriminate murder should fall on the guiltless.

Indeed the mother had done no wrong. She only happened to belong to one of the nations who are struggling against a barbaric tyranny. In that reckless crusade which the Central Powers are waging against all the higher laws of morality and civilization, some of the heaviest of the blows fall on the defenceless. It is this appalling inhumanity, this godless desire to maim and wound and kill, which nerves the" arms of the Allies, who know that in a case like this they are fighting for freedom and for the Divine laws of mercy and loving-kindness.

And it is for the young especially that the war is being waged, young boys and young girls like the motherless child in the picture, in order that they may inherit a Europe which shall be free from the horrible burden of German militarism, and be able to live useful lives in peace and quietness. No, little girl, mother did no wrong! But we should be guilty of the deepest wrong if we did not avenge her death and that of other similar victims by making such unparalleled crimes impossible hereafter.

IV. L. COURTNEY. 


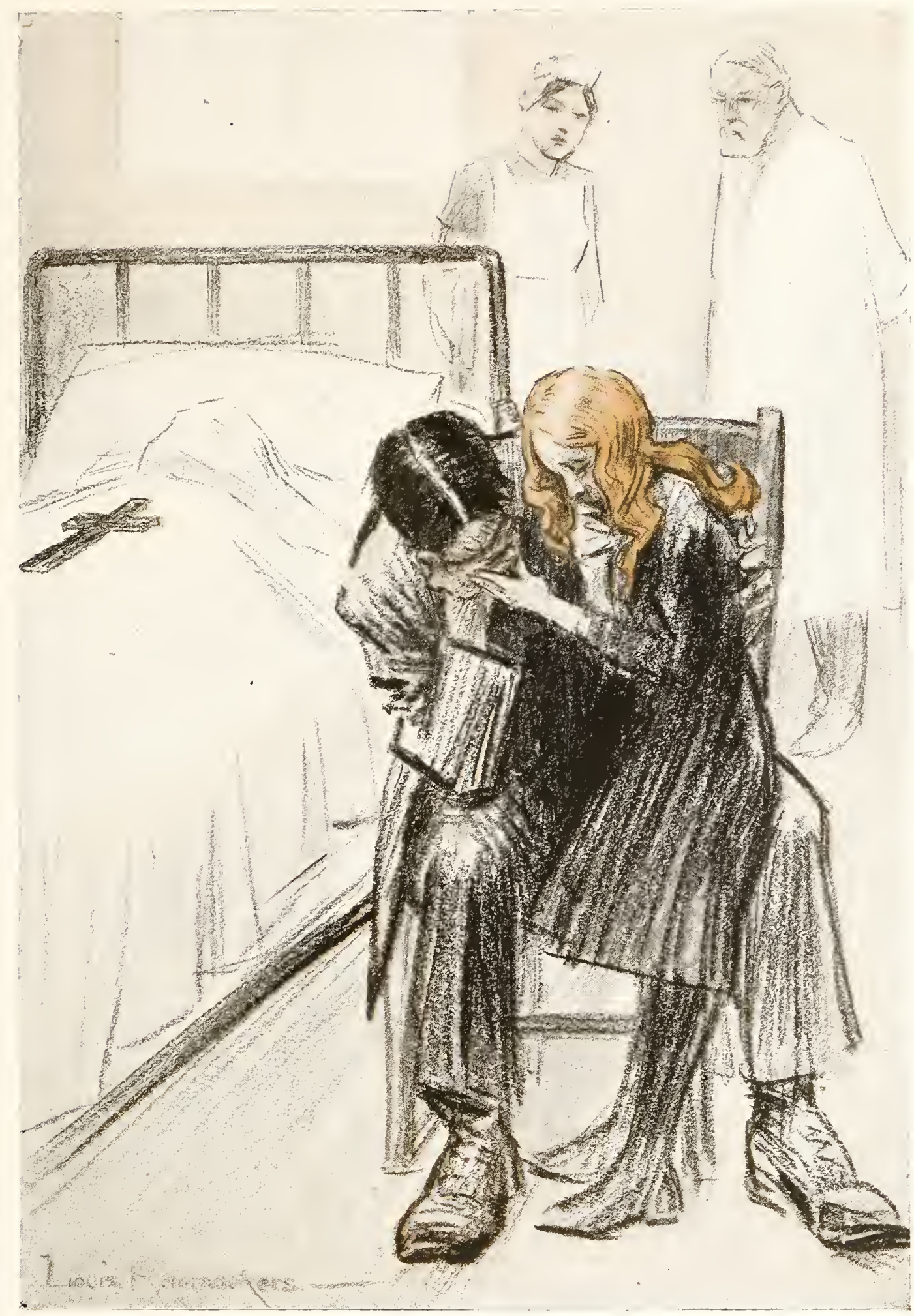

THE ZEPPELIN TRIUMPH

"But Mother had done nothing wrong, had she, Daddy?" 


\section{Keeping Out the Enemy}

HE Prussian turns everything to account, from the scrapings of the pig-trough to the Austrian Emperor.

The Bavarian lists, the Saxon lists, the Austrian liststhese are all only indications of injuries to the Prussian's life-saving waistcoat. If this war is to be a war to the last penny and the last man, the last Austrian will die before the last Saxon, the last Saxon before the last Bavarian, the last Bavarian before the last Prussian--and the last Prussian will not die: he will live to clutch at the last penny.

And the pity of it is that the Austrian is quite a good fellow, the Saxon is a decent sort of man, the Bavarian is chiefly a brute in drink, whilst the Prussian-we all know what the Prussian is, the black centre of hardness, the incarnation of the shady trick, and the very complex soul of mechanical efficiency.

The Hohenzollern here makes a sandbag of the Hapsburg, of whom Fate has already made a football.

Fate has always been behind the Hapsburg for his own sins and those of his house. She has made him kneel at last.

\section{H. DE VERE STACPOOLE.}




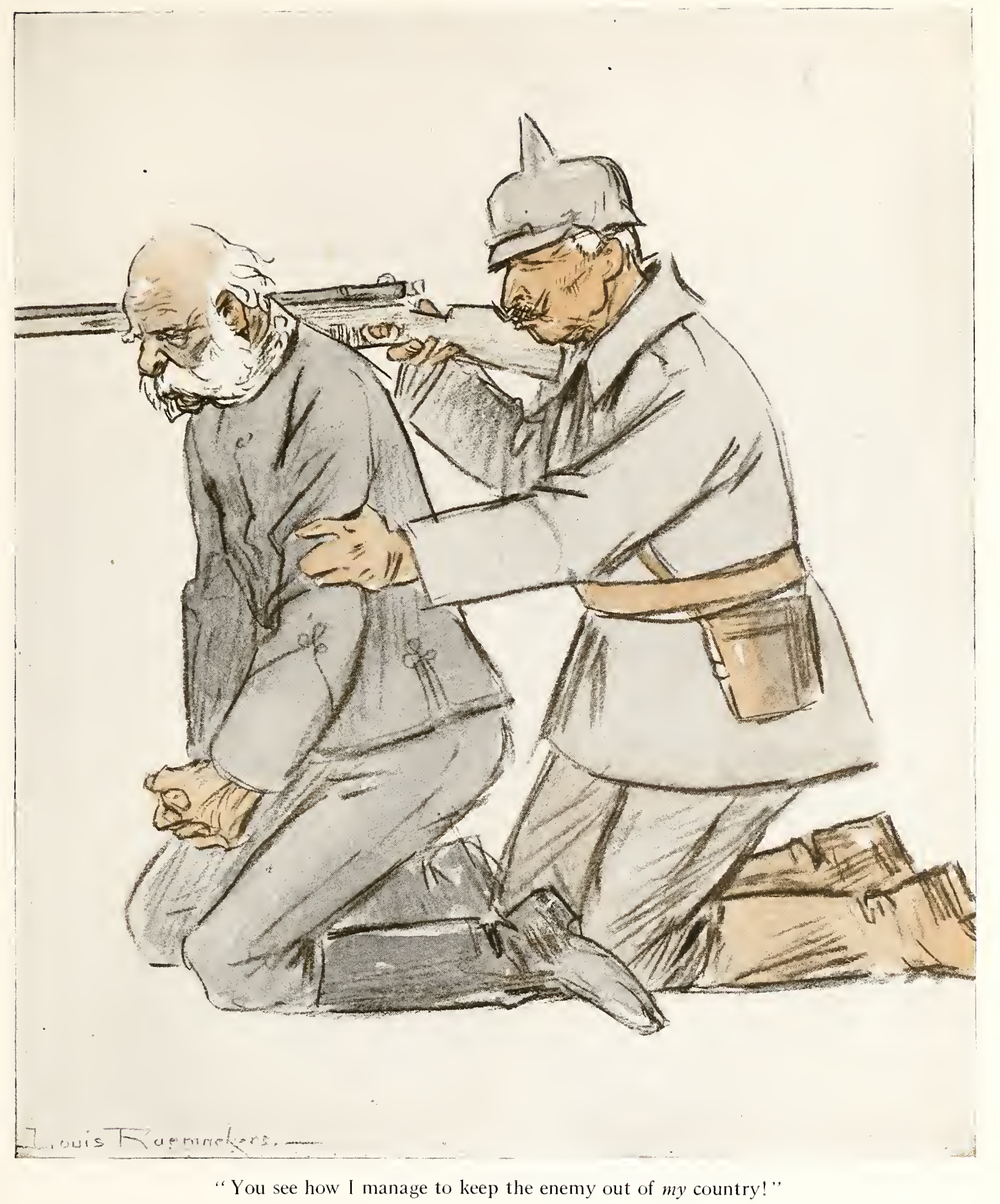




\section{The German Offer}

T HE German claim-not the Austrian nor the Turk, for the alliance following Germany is to be allowed little force-is that, the civilization of Europe now being defeated, a Roman pride may be generous to the fallen. Before modern Germany is routed, as may be seen in the features of its citizens, the nobility of its public works, and the admirable, restrained, and classic sense of its literature, this generosity to a humbled world will take the form of letting nations, of right independent, enjoy some measure of freedom under a German suzcrainty. In the matter of property the magnanimous descendants of Frederick and William the Great will restore the machines which cannot be wrenched from their concrete beds, and the walls of the manufactories. More liquid property, such as jewellery, furniture, pictures-and coin-it will be more difficult to trace. In any case, Europe may breathe again, though with a shorter breath than it did before Germany conquered at the Marne. . . . This is the majestic vision which the subtle diplomats of Berlin present to the admiration of the neutral Powers, happily free from wicked passions of war, and not blinded, as are the British, French, Russians, Italians, Belgians, and the Serbians, by petty spite. Their audience, their triple audience, is part of Greece, some of the public of Spain, and sections of that of the United States. To the French and the British armies in the West, to the Russians in the East, and to the Italians upon their frontiers, the terms appear insufficient. Therein would seem to lie the gravity of Prussia's case. These belligerent Powers will go so far as to demand more than the mere restoration of stolen property, from cottage furniture to freedom. And their anger has risen so high that they even propose to make the acquirer of these goods suffer very bitterly indeed. What plea he will then raise under discomforts more serious than those he has caused to the peasants of Flanders and of Poland, and how those pleas will affect his neutral audience, will have no effect whatever on the result of the war, or on his own unpleasing fate. Those appeals will have a certain interest, however, because we know from the past that the German mind is unstable. Within fifteen short months it proposed the annihilation of the French armies and the occupation of Paris. It failed. It next offered terms upon suffering defeat. It withdrew them. It next made certain at least of a conquest of Russia, failed again, offered terms again, withdrew them again; was directed to the blockading of England, failed; thought Egypt better, and then changed its mind. It was but yesterday in the mood that this cartoon suggests; to-morrow its mood will have utterly changed again, probably to a whine, perhaps to a scream. Such instability is rare in the history of nations which purpose a conquest of others, and it is a very poor furniture for the mind. 


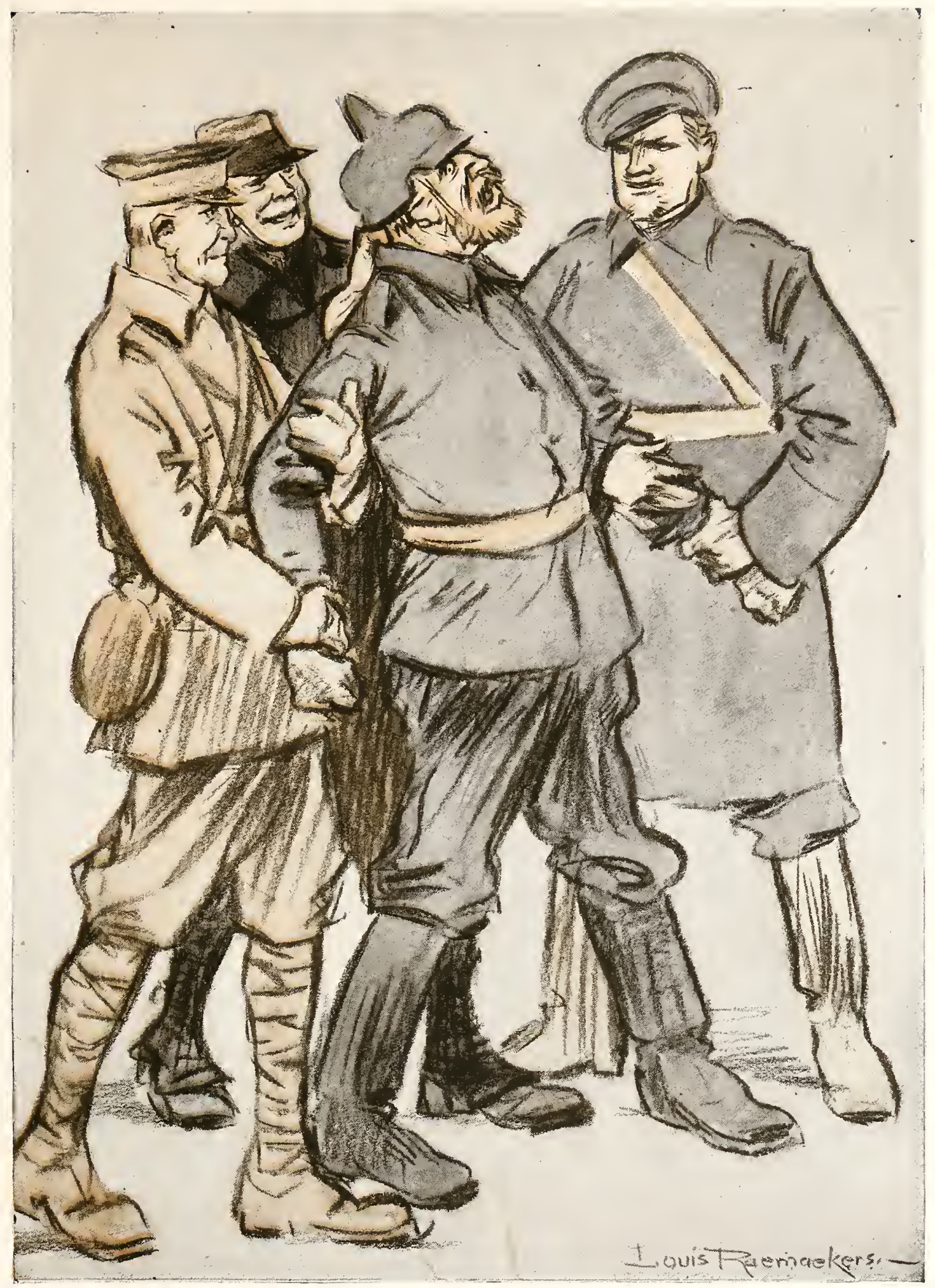

The German : "If you will let me keep what I have, I will let you go." 


\section{The Wolf Trap}

$7 \mathrm{HE}$ wolf is not perhaps the beast by which one would most wish one's country to be represented. But the wolf, like every animal when defending its dearest, and when assailed with treachery, has its nobility. And the Roman she-wolf certainly has had in all ages her dignity and her force.

\footnotetext{
"Thy nurse will hear no master,

Thy nurse will bear no load,

And woe to them that spear her,

And woe to them that goad.

When all the pack loud baying

Her bloody lair surrounds,

She dies in silence biting hard

Amidst the dying hounds."
}

Italy certainly calls not only for our sympathy, but for our admiration. She has had a very difficult course to steer. The ally for so long of Germany and Austria, if owing them less and less as time went on, it was difficult for her to break with them. But the day came when she had to break with them, and once again "act for herself." She told them a year ago she would be a party to no aggressive or selfish war, she would be no bully's accomplice. She "denounced"-it is a good word-such a compact. Non haec in foedera veni.

Then it was, when the she-wolf showed her teeth, that they offered to give her what was her own. But what would the Trentino be worth if Germany and Austria were victorious? No, the wolf is right, "she must fight for it," and behind Austria's underhanded treachery stands Germany's open violence and guns.

And Italy loves freedom. This war is a war made by her people. As of old her King and her diplomats go with them in this new Resorgimento. And the she-wolf must beware the trap. She needs the spirit again not only of her people and of Garibaldi and of Victor Emmanuel, but of Cavour. And she has it.

The cartoon suggests all the elements of the situation. The wolf ponders with turned head, half doubtful, half desperate. The poor little cub whimpers pitifully. The hunters dissemble their craft, the trap waits in the path ready to spring. It is not even concealed. Is that the irony of the artist, or is it only due to the necessity of making his meaning plain? Whichever it is, it is justified.

HERBERT WARREN. 


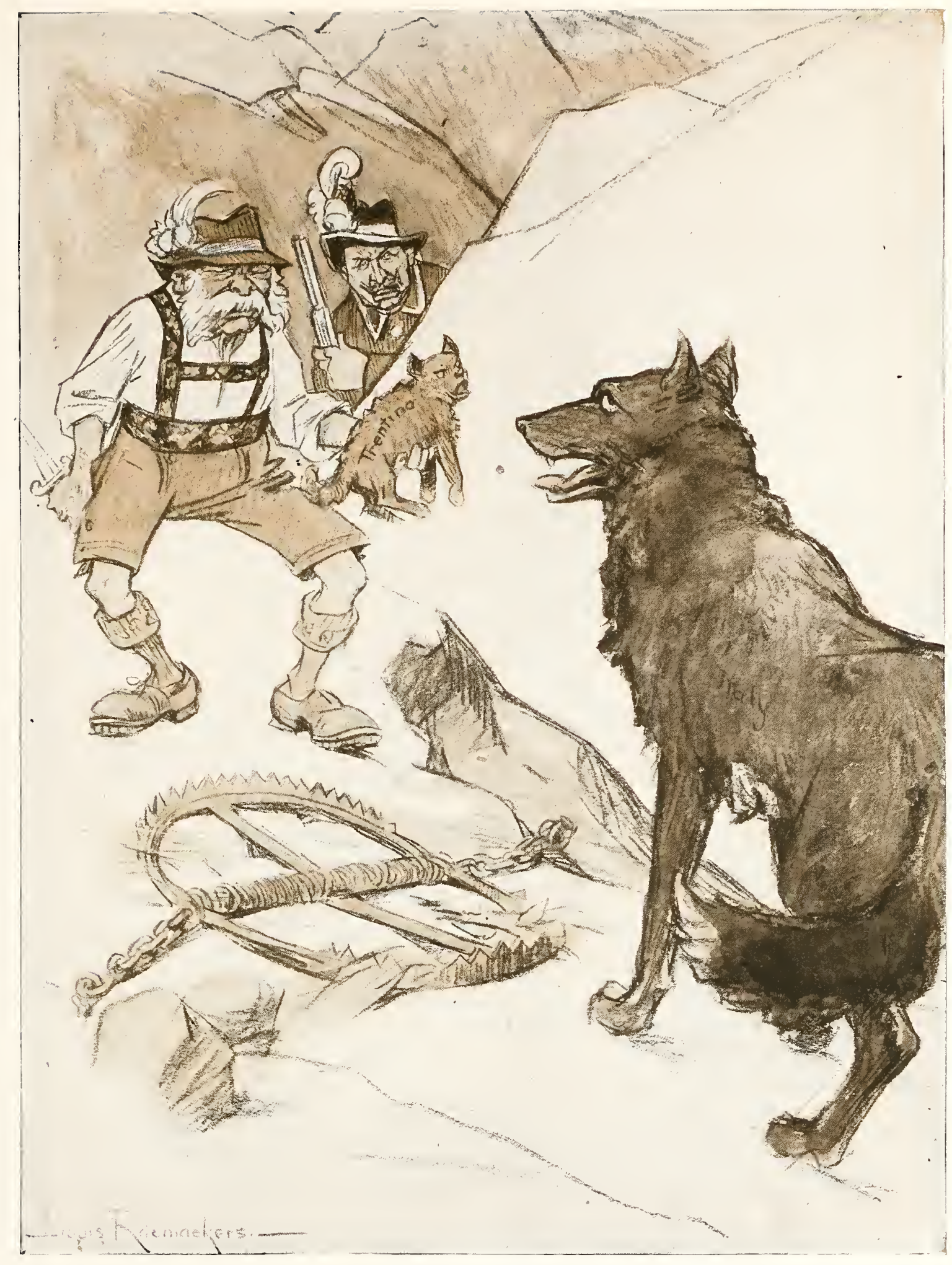

THE WOLF TRAP

"You would make me believe that I shall have my cub given back to me, but I know I shall have to fight for it." 


\section{Ahasuerus II.}

$\mathrm{T}$ HE legend of the Wandering Jew obsessed the imagination of the Middle Age. The tale, which an Armenian bishop first told at the Abbey of St. Albans, concerned a doorkeeper in the house of Pontius Pilate-or, as some say, a shoemaker in Jerusalem -who insulted Christ on His way to Calvary. He was told by Our Lord, "I will rest, but thou shalt go on till the Last Day." Christendom saw the strange figure in many places-at Hamburg and Leipsic and Lubeck, at Moscow and Madrid, even at far Bagdad. Goodwives in the little mediæval cities, hastening homeward against the rising storm, saw a bent figure posting through the snow, with haggard face and burning eyes, carrying his load of penal immortality, and seeking in vain for "easeful death." There is a profound metaphysic in such popular fancies. Good and evil are alike eternal. Arthur and Charlemagne and Ogier the Dane are only sleeping and will yet return to save their peoples; and the Wandering Jew staggers blindly through the ages, seeking the rest which he denied to his Lord.

In George Meredith's “Odes in Contribution to the Song of French History" there is a famous passage on Napoleon. France, disillusioned at last,

\footnotetext{
"Perceives him fast to a harsher Tyrant bound;

Self-ridden, self-hunted, captive of his aim;

Material gradeur's ape, the Infernal's hound."
}

That is the penalty of mortal presumption. The Superman who would shatter the homely decencies of mankind and set his foot on the world's neck is himself bound captive. He is the slave of the djinn whom he has called from the unclean deeps. There can be no end to his quest. Weariness does not bring peace, for the whips of the Furies are in his own heart.

The Wandering Jew of the Middle Age was a figure sympathetically conceived. He had still to pay the price in his tortured body, but his soul was at rest, for he had repented his folly. Raemaekers in his cartoon follows the conception of Gustave Doré rather than that of the old fabulists. The modern Ahasuerus has no surety of an eventual peace. We have seen the German War Lord flitting hungrily from Lorraine to Poland, from Flanders to Nish, watching the failure of his troops before Nancy and Ypres, inditing grandiose proclamations to Europe, prophesying a peace which never comes. He is a figure worthy of Greek tragedy. The $\hat{v} \beta \rho \iota s$ which defied the gods has put him outside the homely consolations of mankind. He has devoted his people to the Dance of Death, and himself, like some new Orestes, can find no solace though he seek it wearily in the four corners of the world.

JOHN BUCHAN. 


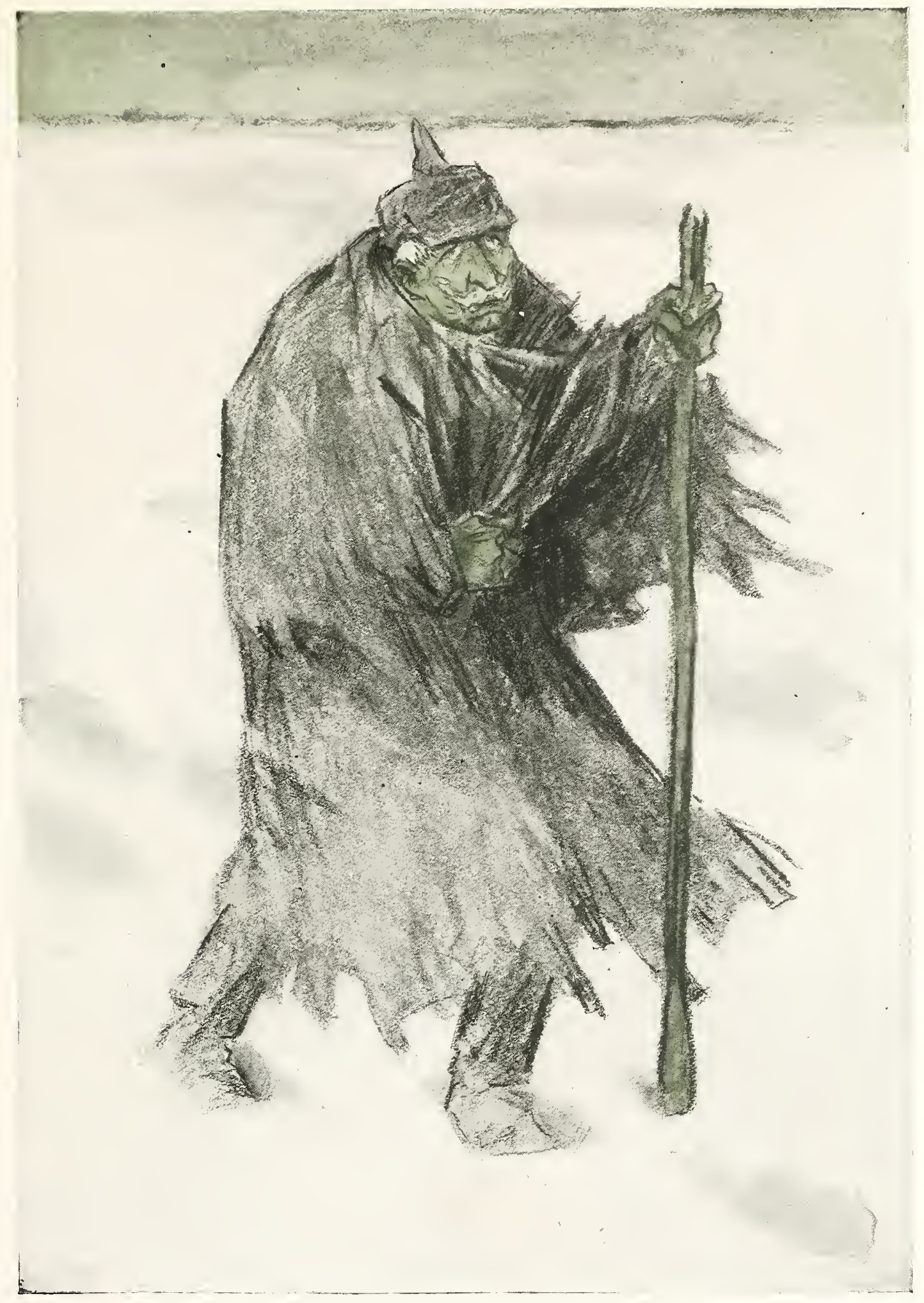

AHASUERUS RETURNS

"Once I drove the Christ out of my door; now I am doomed to walk from the Northern Seas to the Southern, from the Western shores to the Eastern mountains, asking for Peace, and none will give it to me."-From the Legend of the "Wandering Jew." 


\section{Our Candid Friend}

THE position of Holland and Denmark is one of excruciating anxiety to the citizens of those countries. They know that the Allies are fighting the battle of their own political existence, but they are so hypnotized with well-founded terror of the implacable tyrant on their flank that they are not only bound to neutrality, but are. afraid to express their sympathies too plainly. Dutch editors have been admonished and punished under pressure from Berlin; the brilliant artist of these cartoons is in danger on his native soil. A leading German newspaper has lately announced that "we will make Holland pay with interest for these insults after the war." A German victory would inevitably be followed in a few years by the disappearance from the map of this gallant and interesting little nation, our plucky rival in time past, our honoured friend to-day. No nation has established a stronger claim to maintain its independence, whether we consider the heroic and successful struggles of the Dutch for religious and political liberty, their triumphs in discovery, colonization, and naval warfare, their unique contributions to art, or the manly and vigorous character of their people. It is needless to say that we have no designs upon any Dutch colony!

THE DEAN OF ST. PAUL'S. 


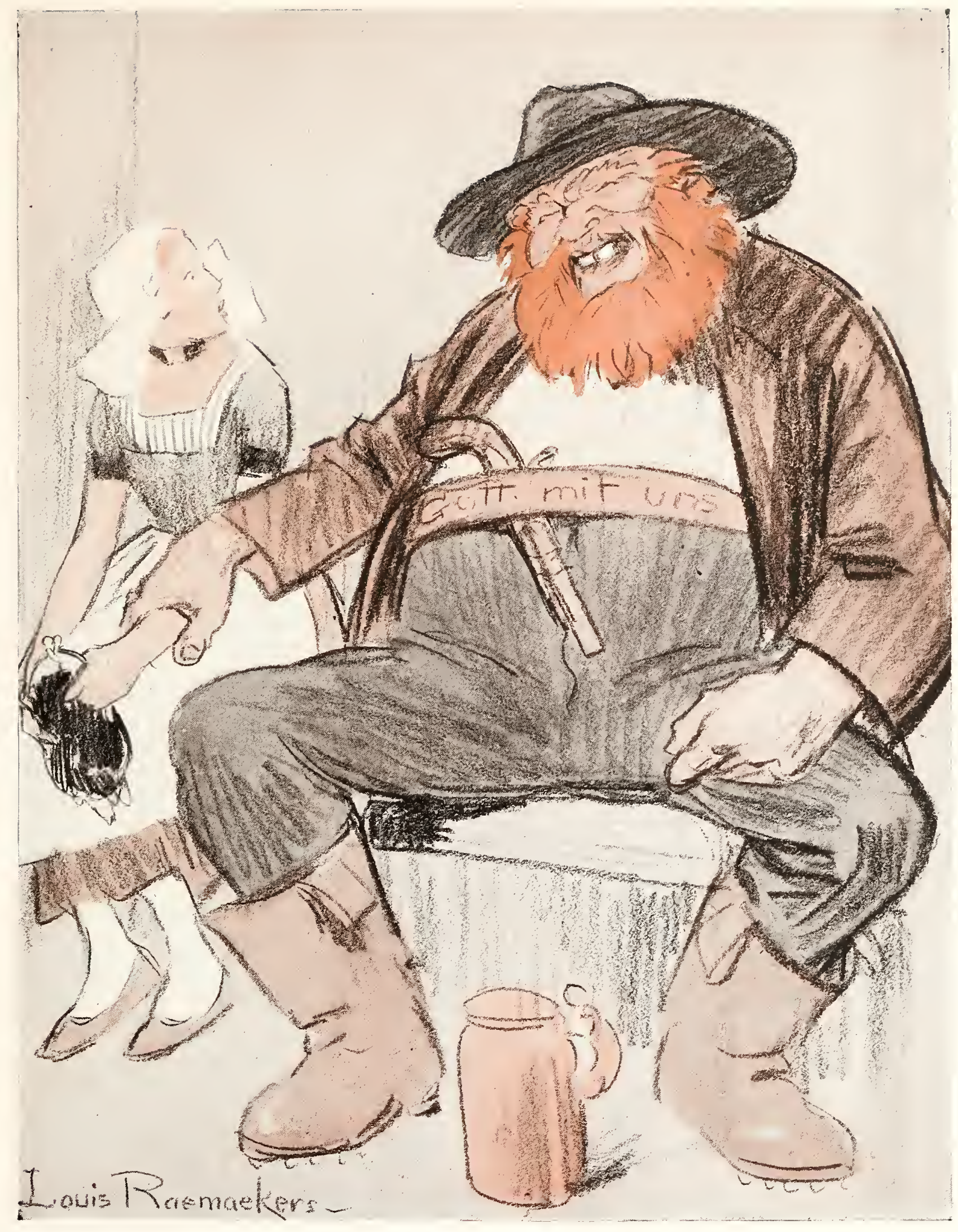

OUR CANDID FRIEND

Germany, to Holland: "I shall have to swallow you up, if only to prevent those English taking your colonies." 


\section{Peace and Intervention}

$\mathrm{H}$

ERE is pictured a grim fact that the Peace cranks would do well to see plainly. The surgeon who is operating on a cancer case cannot allow himself to be satisfied with merely the removal of the visible growth which is causing such present agony to the patient. He must cut and cut deep, must go beyond even the visible roots of the disease, slice down into the clear, firm flesh to make sure and doubly sure that he has cut away the last fragment of the tainted tissues. Only by doing so can he reasonably hope to prevent a recurrence of the disease and the necessity of another operation in the years to come. And so only by carrying on this war until the last and least possibility of the taint of militarism remaining in the German system is removed can the Allies be satisfied that their task is complete. Modern surgery has through anæsthetics taken away from a patient the physical pain of most operations, but modern War affords no relief during its operation. That, however, can be held as no excuse for refusing to "use the knife." What would be said of the surgeon who, because an operation - a life-saving operation-was causing at the time even the utmost agony, stayed his hand, patched up the wound, was content only to stop the momentary pain, and to leave firm-rooted a disease which in all human probability would some time later break out again in all its virulence? What would be said of such a surgeon is only in lesser degree what would be said by posterity of the Allies if they consented or were persuaded to apply the bandage and healing herbs of Peace to the disease of Militarism, to make a surface cure and leave the living tentacles of the disease to grow again deep and strong. But here at least the doctors do not disagree. Once and for all the Ally surgeons mean to make an end to Militarism. The sooner the Peace cranks and Germany realize that the sooner the operation will be over.

BOYD CABLE. 


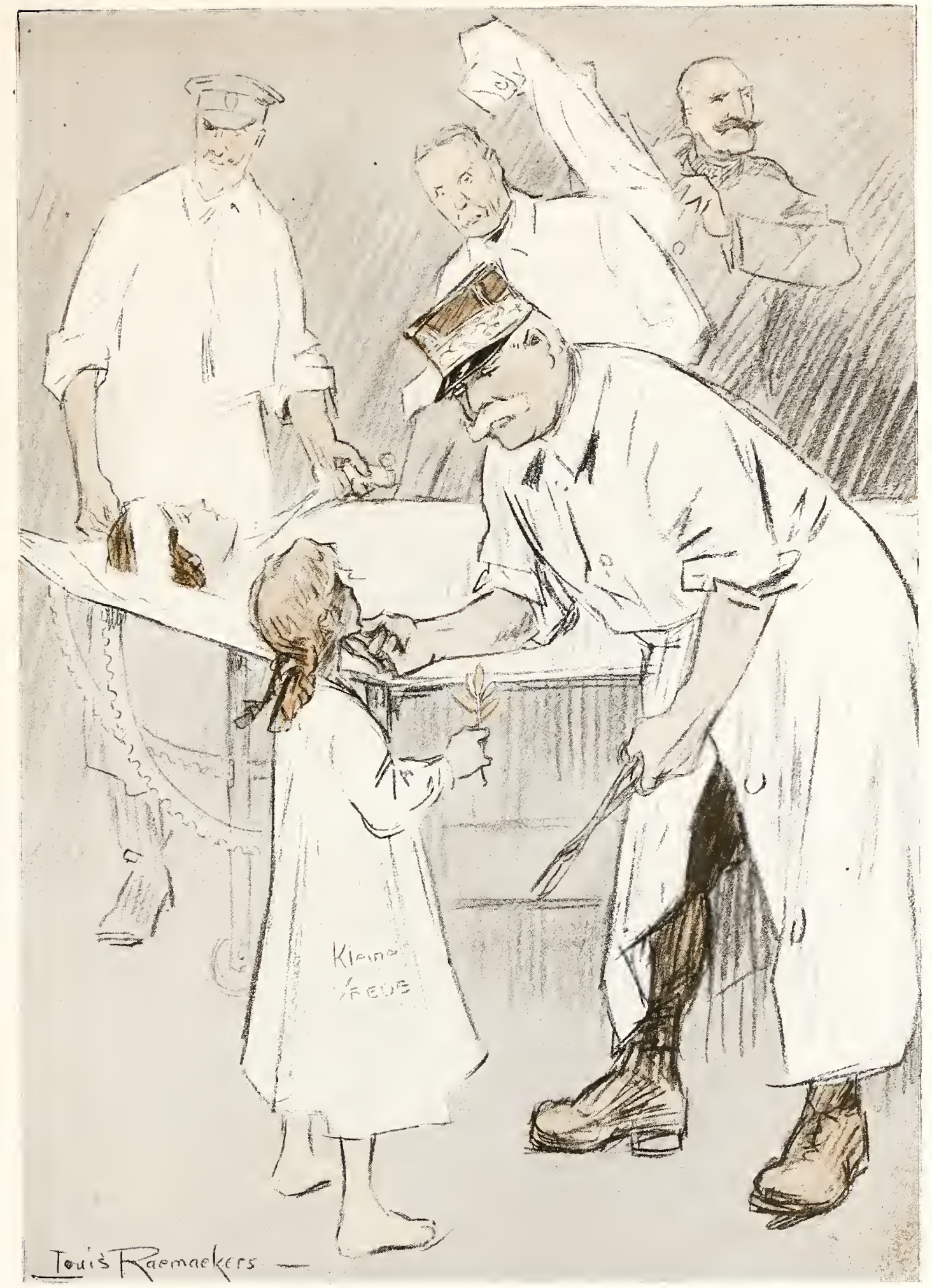

PEACE AND INTERVENTION-GERMAN MILITARISM ON THE OPERA'TING-TABLE

"For the sake of the world's future we must first use the knife." 


\section{Little Red Riding Hood}

T F YOU wish to see the position of Holland look at the map of Europe as it was before August 4, 1914, and the map of Europe as it is to-day.

In 1914 Holland lay overshadowed by the vast upper jaw-bone of a monster-Prussia - a jaw-bone reaching from the Dollart to Aixla-Chapelle.

In August and September, 1914, Prussia, by the seizure of Belgium, developed a lower jaw-bone reaching from Aix-la-Chapelle to Cassandria on the West Schelde. To-day Holland lies gripped between these two formidable mandibles that are ready and waiting to close and crush her. For years and years Prussia has been waiting to devour Holland. Why? For the simple reason that Holland is rich in the one essential thing that Prussia lacks--coast-line.

Look again at the map and see how Holland and Belgium together absolutely wall Prussia in from the sea. Belgium has been taken on by Prussia; if we do not tear that lower jaw from Prussia, Holland will be lost, and the sea-power of England threatened with destruction.

The ruffian with the automatic pistol waiting behind the tree requires the life as well as the basket of the little figure advancing toward him.

He has been in ambush for forty years.

H. DE VERE STACPOOLE. 


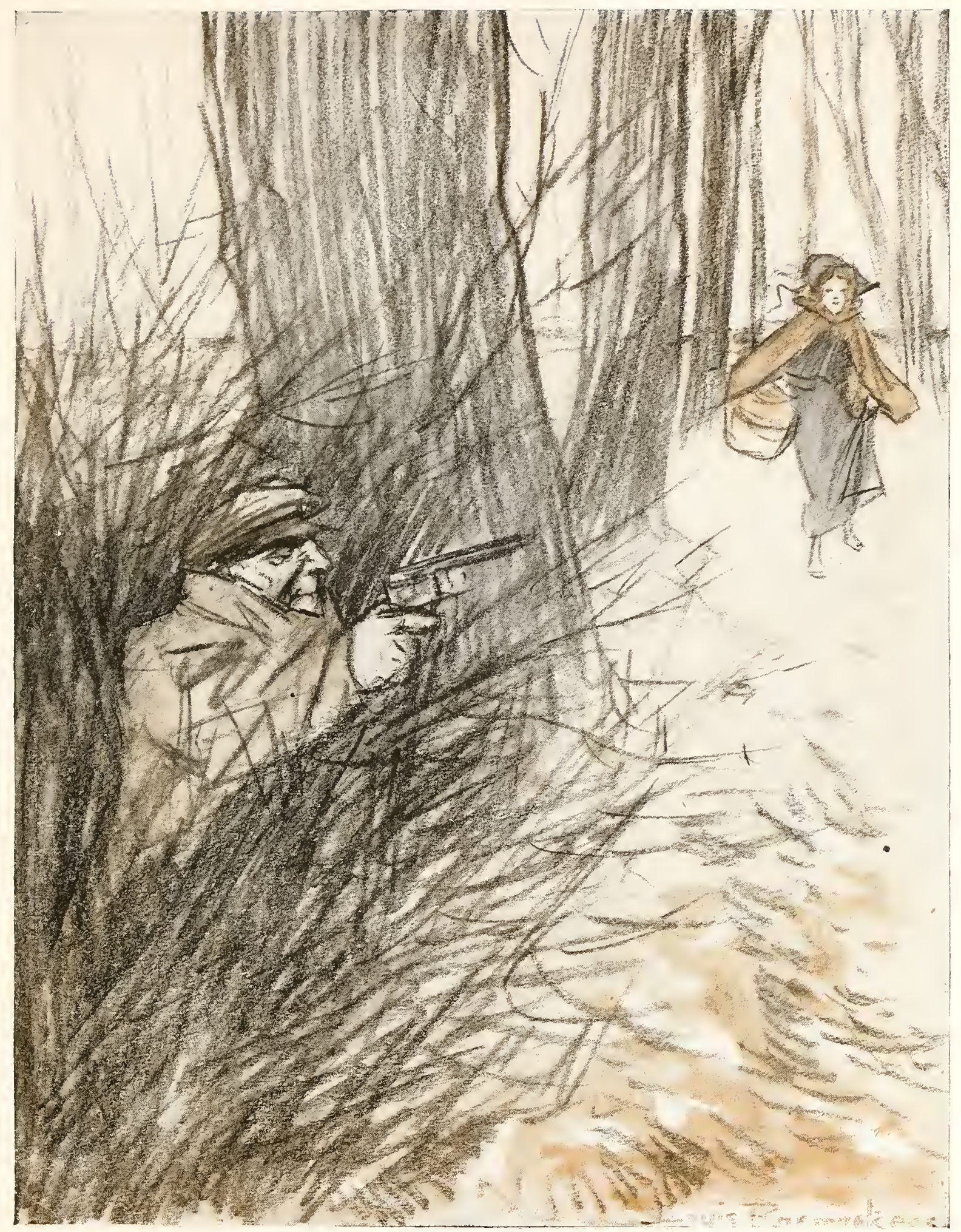

LITTLE RED RIDING HOOD

Germany lying in wait for Holland. 


\section{The Sea Mine}

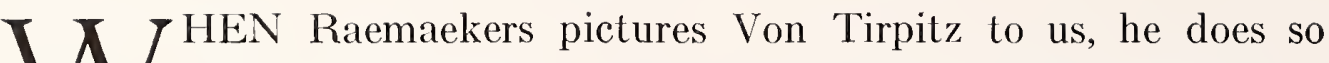
with savage scorn. He is not the hard-bitten pirate of story_but a senile, crapulous, lachrymose imbecile; an object of derision. He fits more with one of Jacob's tales of longshore soakers, than with the tragedies that have made him infamous. But when he draws Von Tirpitz's victims, the touch is one of almost harrowing tenderness. The Hun is a master of many modes of killing, but however torn, or twisted, or tortured he leaves the murdered, Raemackers can make the dreadful spectacle bearable by the piercing dignity with which he portrays the dead. In none of these cartoons is his sxva indignalio rendered with more sheer beauty of design, or with a craftsmanship more exquisite, than in this monument to the sea-mined prey. The symbolism is perfect, and of the essence of the design. The dead sink slowly to their resting-place, but the merciful twilight of the sea veils from us the glazed horror of the eyes that no piety can now close. Even the dumb, senseless fish shoots from the scene in mute and terrified protest, while from these poor corpses there rise surfaceward the silver bubbles of their expiring breath. One seems to see crying human souls prisoned in these spheres. And it is, indeed, such sins as these that cry to Heaven for vengeance. Blood-guiltiness must rest upon the heads of those that do them, upon the heads of their children--aye, and of their children's children too. This exquisite and tender drawing is something more than the record of inexpiable crime. It is a prophecy. And the prophecy is a curse.

ARTHUR POLLEN. 


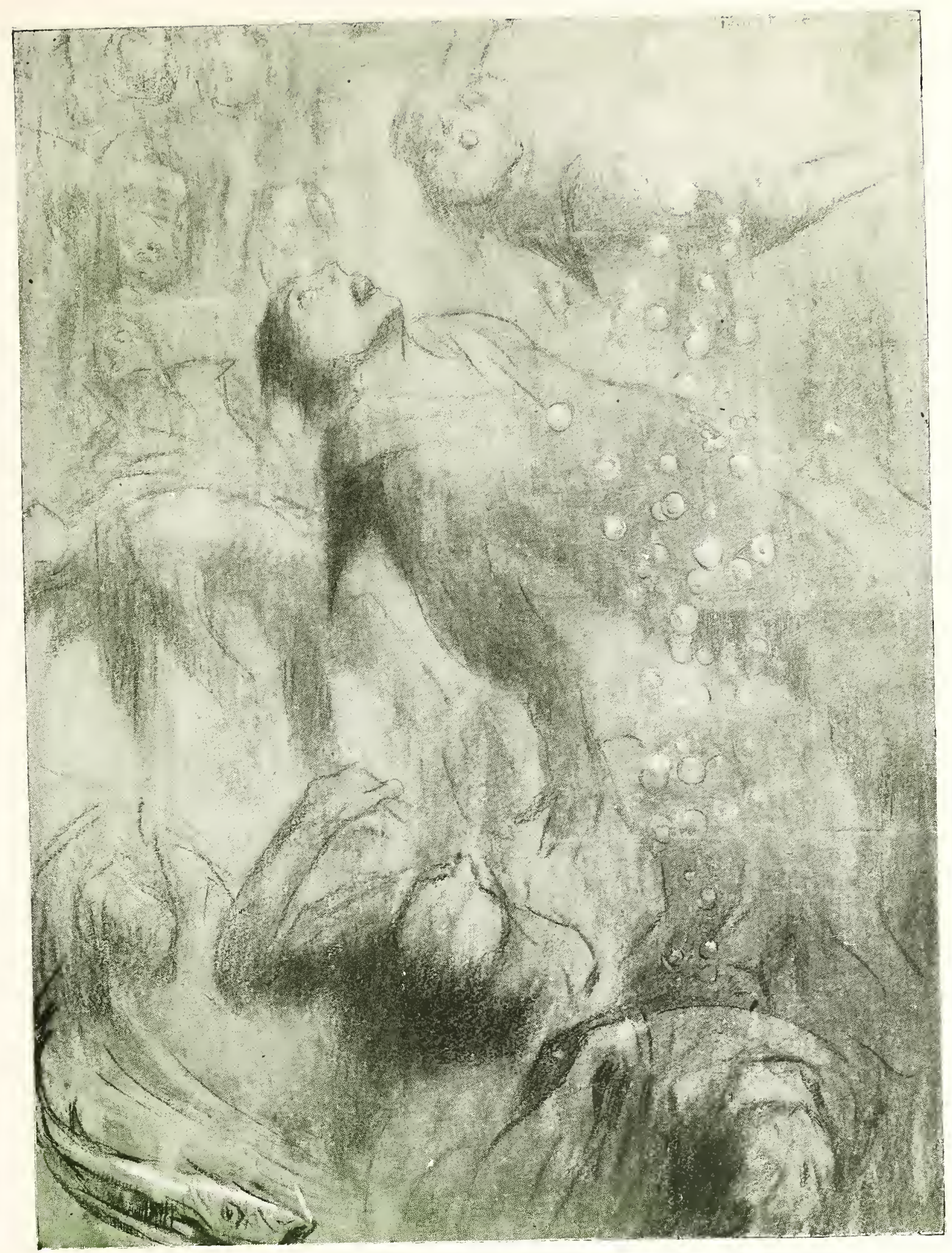

THE SEA MINE 


\section{"Seduction"}

T HE cartoon in which the Prussian is depicted as saying to his bound and gagged victim, "Ain't I a lovable fellow?" is one of the most pointed and vital of all pictorial, or indeed other, criticisms on the war. It is very important to note that German savagery has not interfered at all with German sentimentalism. The blood of the victim and the tears of the victor flow together in an unpleasing stream. The effect on a normal mind of reading some of the things the Germans say, side by side with some of the things they do, is an impression that can quite truly be conveyed only in the violent paradox of the actual picture. It is exactly like being tortured by a man with an ugly face, which we slowly realize to be contorted in an attempt at an affectionate expression. In those soliloquies of self-praise which have constituted almost the whole of Prussia's defence in the international controversy, the brigand of the Belgian annexation has incessantly said that his apparent hardness is the necessary accompaniment of his inherent strength. Nietzsche said: "I give you a new commandment: Be hard." And the Prussian says: "I am hard," in a prompt and respectful manner. But, as a matter of fact, he is not hard; he is only heavy. He is not indifferent to all feelings; he is only indifferent to everybody else's feelings. At the thought of his own virtues he is always ready to burst into tears. His smiles, however, are even more frequent and more fatuous than his tears; and they are all leers like that which Mr. Raemaekers has drawn on the face of the expansive Prussian officer in the arm-chair. Compared with such an exhibition, there is something relatively virile about the tiger cruelty which has occasionally defaced the record of the Spaniard or the Arab. But to be conquered by such Germans as these would be like being eaten by slugs.

G. K. CHESTERTON. 


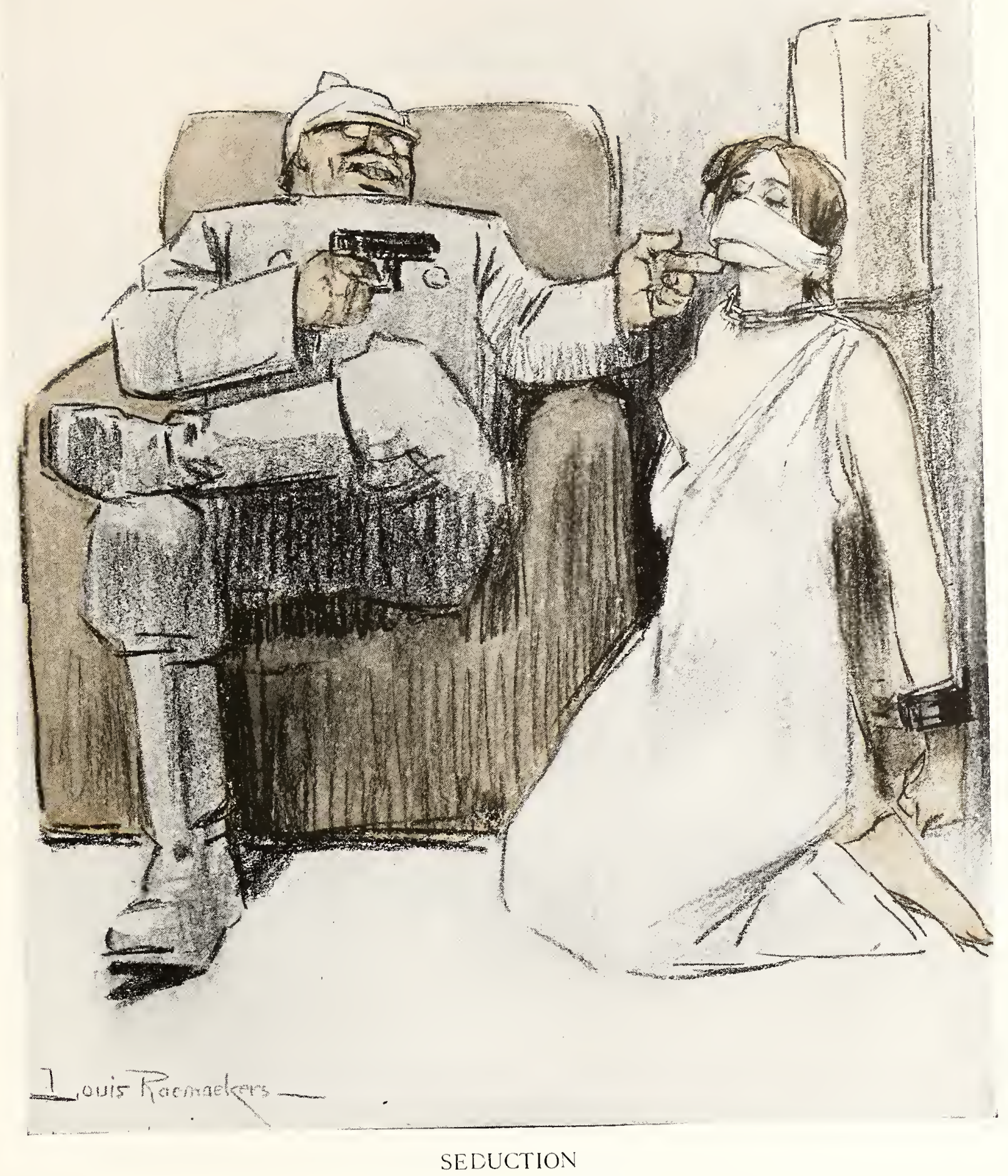

"Ain't 1 a lovable fellow ?" 


\section{Murder on the High Seas}

HE recent descent of so many of her citizens from the people now warring in Europe has of necessity prevented America from looking on events in Europe with a single eye. But the predominant American type and the predominant American frame of mind are still typified by the lithe and sinuous figure of the New England pioneer. It is his tradition to mind his own business, but it is also his business to see that none of the old monarchies make free with his rights or with his people. And he stands for a race that has been cradled in wars with savages. No one knows better the methods of the Apache and the Mohawk, and when women and children fall into such pitiless hands as these, it goes against the grain with Uncle Sam to keep his hands off them, even if the women and children are not his own. He would like to be indifferent if he could. He would prefer to smoke his cigar, and pass along, and believe those who tell him that it is none of his affair. But when he does look-and he cannot help looking-he sees a figure of such heavy bestiality that his gorge rises. He must keep his hands clenched in his pockets lest he soils them in striking down the blood-stained gnome before him.

Can he restrain himself for good? That angry glint in his eye would make one doubt it. Here, surely, the artist sees with a truer vision than the politician. And if Uncle Sam's anger does once get the better of him, if doubts and hesitations are ever thrust on one side, if he takes his stand where his record and his sympathies must make him wish to be, then let it be noted that this base butcher stands dazed and paralyzed by the threat.

ARTHUR POLLEN. 


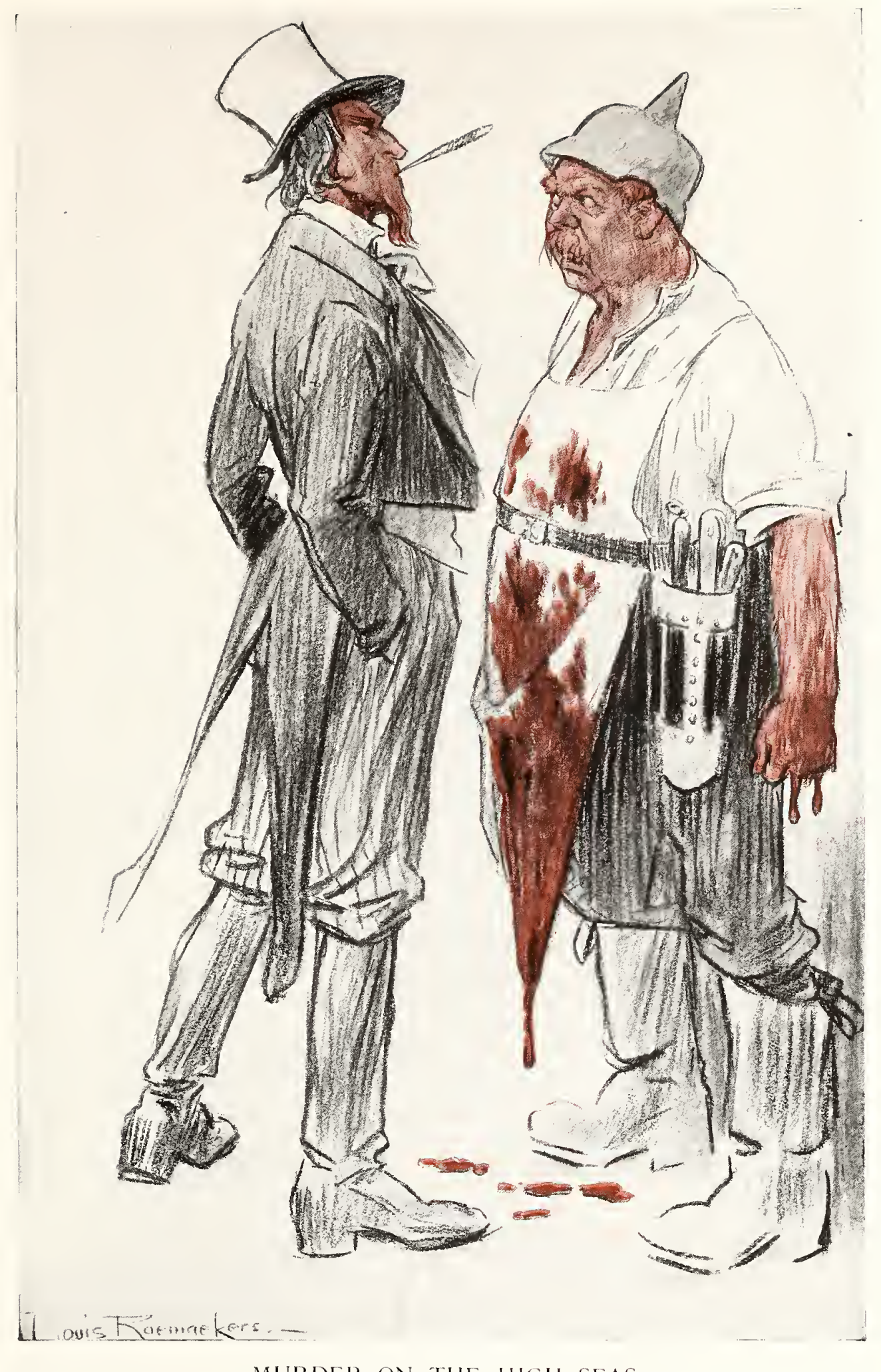

MURDER ON THE IIIGH SEAS

"Well, have you nearly done?" 


\title{
Ad Finem
}

\begin{abstract}
Y-TO your end!-to your end amid the execrations of a A ravaged world! Through all the ages one other only has equalled you in the betrayal of his trust. May your sin come home to you before you go, as did his! May his despair be yours! It is most desperately to be regretted that no personal suffering on your part, in this life at all events, can ever adequately requite you for the desolations you have wrought.
\end{abstract}

Outrage on outrage thunders to the sky

The tale of thy stupendous infamy,-

Thy slaughterings, - thy treacheries, - - thy thefts,-

Thy broken pacts, - thy honour in the mire,-

Thy poor humanity cast off to sate thy pride;-

'Twere better thou hadst never lived,- or died

Ere come to this.

I heard a great Voice pealing through the heavens,

A Voice that dwarfed earth's thunders to a moan:-

Woe! Woe! Woe, to him by whom this came!

His house shall unto him be desolate

And, to the end of time, his name shall be

$A$ byword and reproach in all the lands

He repined. . . . And his own shall curse him

For the ruin that he brought.

Who without reason draws the sword-

By sword shall perish!

The Lord hath said. . . . So be it, Lord!

JOHN OXENHAM. 


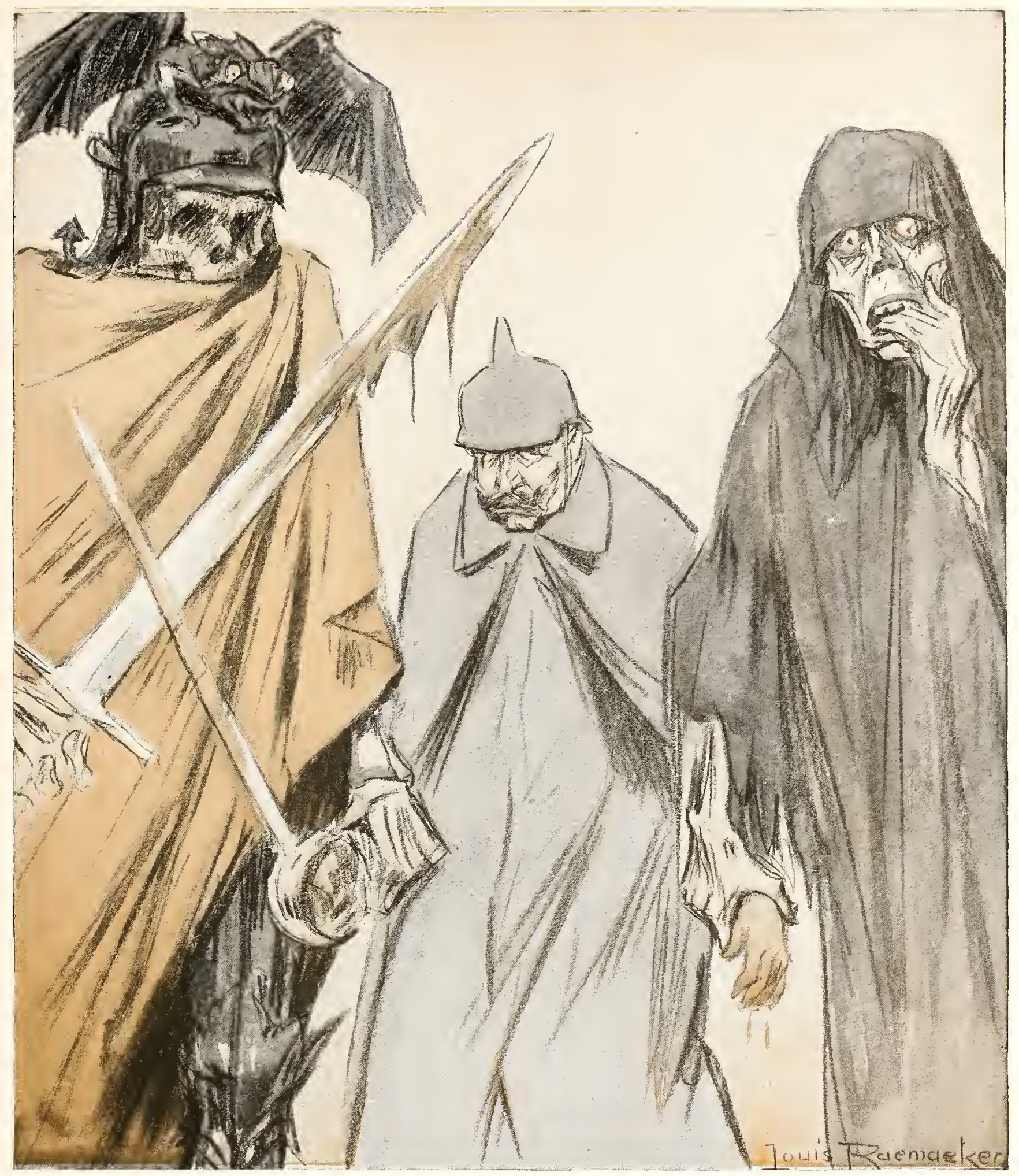

TO THE END

WAR AND Hunger: "Now you must accompany us to the end." THE KAISER : "Yes, to my end." 


\section{"UTSPs}

T T IS the essence of great cartooning to see things simply, and to command the technical resources that shall show the things, so simply seen, in an infinite variety of aspects. No series of Raemaekers' drawing better exemplifies his quality in both these respects than those which deal with Germany's sea crimes.

In the cartoon before us the immediate message is of the simplest. The Kaiser counts the head of British merchantmen sunk. Von Tirpitz counts the cost. But note the subtlety of the personation and environment. The Kaiser has those terrible haunted eyes that have marked the seer's presentment of him from quite an early stage of the war. There can be no ultimate escape from the dreadful vision that has set the seal of despair on this fine and handsome visage. He is shown, not as a sea monster, but as some rabid, evasive, impatient thing, dashing from point to point - as from policy to policy - with the angry swish that tells the unspoken anger failure everywhere compels. For the victories do not bring surrender, nor does frightfulness inspire terror. The merchant ships still put to sea-and the U boats pay the penalty.

The futility of this campaign of murder is typified by making Von Tirpitz, its inventor, an addle-headed seahorse, the nursery comedian of the sea. Stupid and ridiculous bewilderment stares from his foolish

eyes. Another submarine has failed to find a safe viclim in a trading ship, but has been hoisted with its own sea petard. The impotence of the thing!

This conference of the Admirals of the Atlantic, held in the sombre depths, is a biting satire, in its mingled comedy and tragedy, on the effort to win command of the sea from its bottom.

ARTHUR POLLEN. 


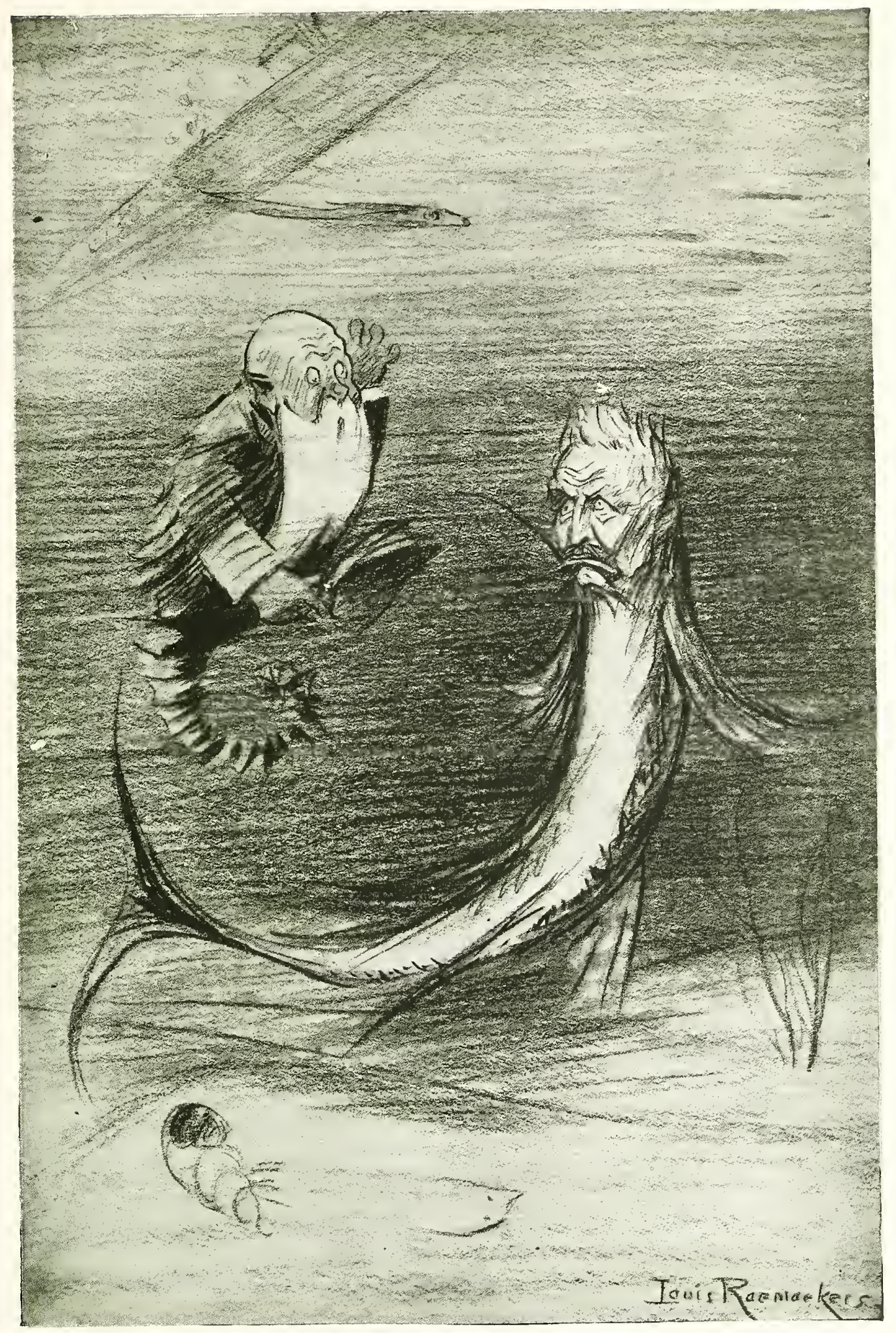

"U’S"

His Majesty : "Well, Tripitz, you've sunk a great many?"

Tirpitz: "Yes, sire, here is another 'U' coming down." 


\section{Mater Dolorosa}

T OU thought to grasp the world; but you shall keep

Its crown of curses nailed upon your brow.

You that have fouled the purpie, broke your vow,

And sowed the wind of death, the whirlwind you shall reap.

Shout to your tribal god to bless the blood

Of this red vintage on the poisoned earth;

Clash cymbals to him, leap and shout in mirth;

Call on his name to stay the coming, cleansing flood.

We are no hounds of heaven, nor ravening band

Of earthly wolves to tear your kingdom down.

We stand for human reason; at our frown

The coward sword shall fall from your accursèd hand.

We do not speak of vengeance; there shall run

No little children's blood beneath our heel.

No pregnant woman suffers from our steel;

But Justice we shall do, as sure as set of sun.

Or short, or long, the pathway of your feet,

Stamped on the faces of the innocent dead,

Must lead where tyrant's road hath ever led.

Alone, O perjured soul, your Justice you shall meet.

No sacrifice the balance of her scale

Can win; no gift of blood and iron can weigh

Against this one mad mother's agony:

In her demented cry a myriad women wail.

The equinox of outraged earth shall blaze

And flash its levin on your infamous might.

Man cries to fellow-man; light leaps to light,

Till foundered, naked, spent, you vanish from our gaze.

EDEN PHILLPOTTS. 


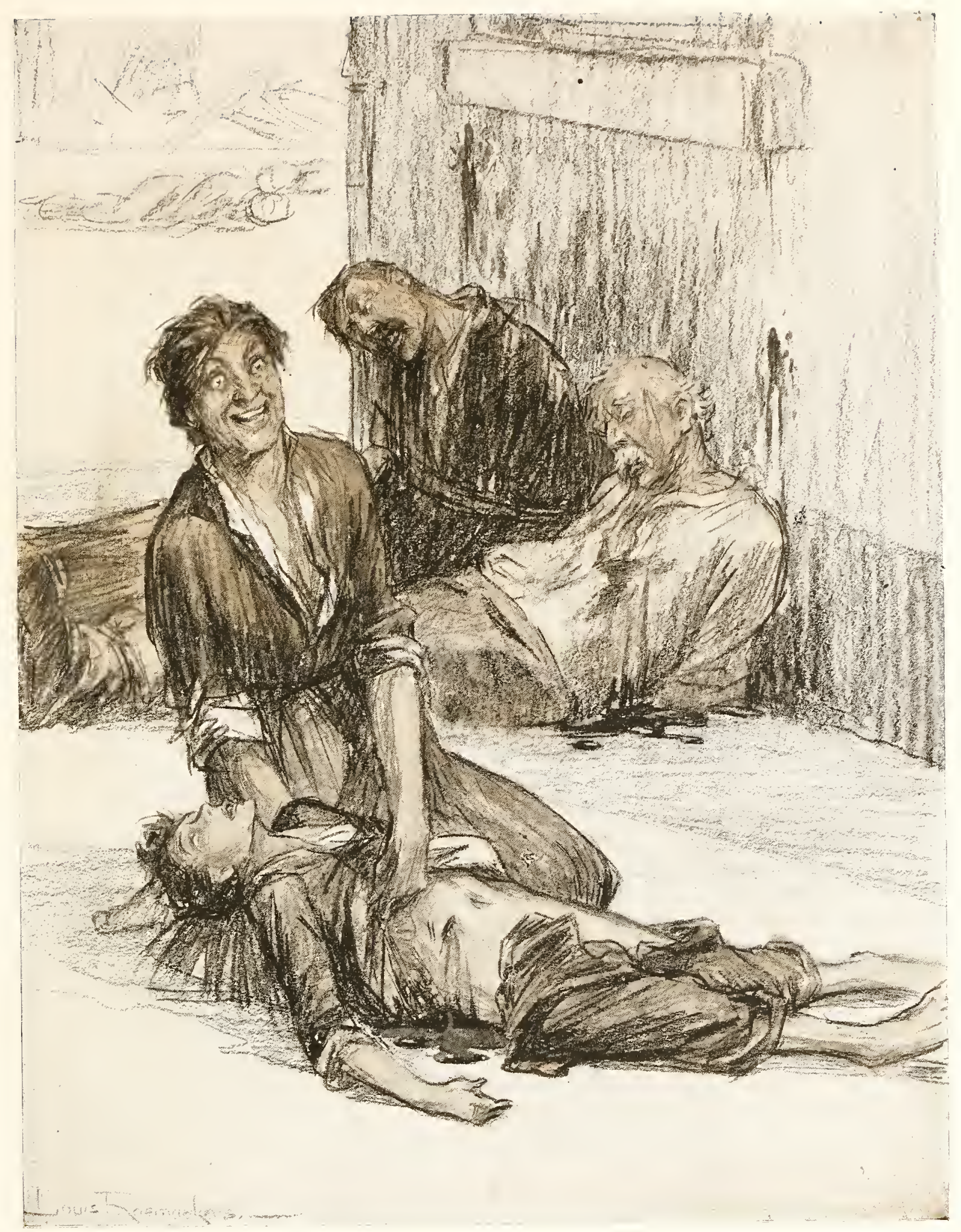

MATER DOLOROSA 


\section{"Gott Strafe Italien!"}

$\mathrm{W}$

HEN Italy, still straining at the leash which held her, helpless, to the strange and unnatural Triplice, began to show signs of awakening consciousness, Germany's efforts to lull her back to the unhappy position of silent partner in the world-crime were characteristic of her methods. Forthwith Italy was loaded with compliments. The country was overrun with "diplomats," which is another name in Germany for spies. Bribery of the most brazen sort was attempted. The newspapers recalled in chorus that Italy was the land of art and chivalry, of song and heroism, of fabled story and manly effort, of honour and loyalty. Hark to the Hamburger Fremdenblatt of February 21, 1915:

"The suggestion is made that Italy favours the Allies. Preposterous! Even though the palsied hand of England-filled with robber gold-be held out to her, Italy's vows, Italy's sense of obligation, Italy's word once given, can never be broken. Such a nation of noblemen could have no dealings with hucksters."

Germany is, indeed, a fine judge of a nation's "word once given" and a nation's "vows," which its Chancellor unblushingly declared to be mere scraps of paper. Now let us see what the Hamburger Nachrichten had to say about Italy immediately after her secession from the Triple Alliance: “Nachrichten, June 1, 1915. That Italy should have joined hands with the other noble gentlemen, our enemies, is but natural. It would, of course, be absurd-where all are brigands -were the classical name of brigandage not included in the number. - . We do not propose to soil our clean steel with the blood of such filthy Italian scum. With our cudgels we shall smash them into pulp."

"Gott strafe Italien" indeed! Bombs on St. Mark's in Venice, on the Square of Verona, on world treasures unreplaceable. The poisoned breath of Germany carries its venom into the land of sunshine and song, whose best day's work in history has been to wrest itself free from the grip of the false friend.

RALPH D. BLUMENFELD. 


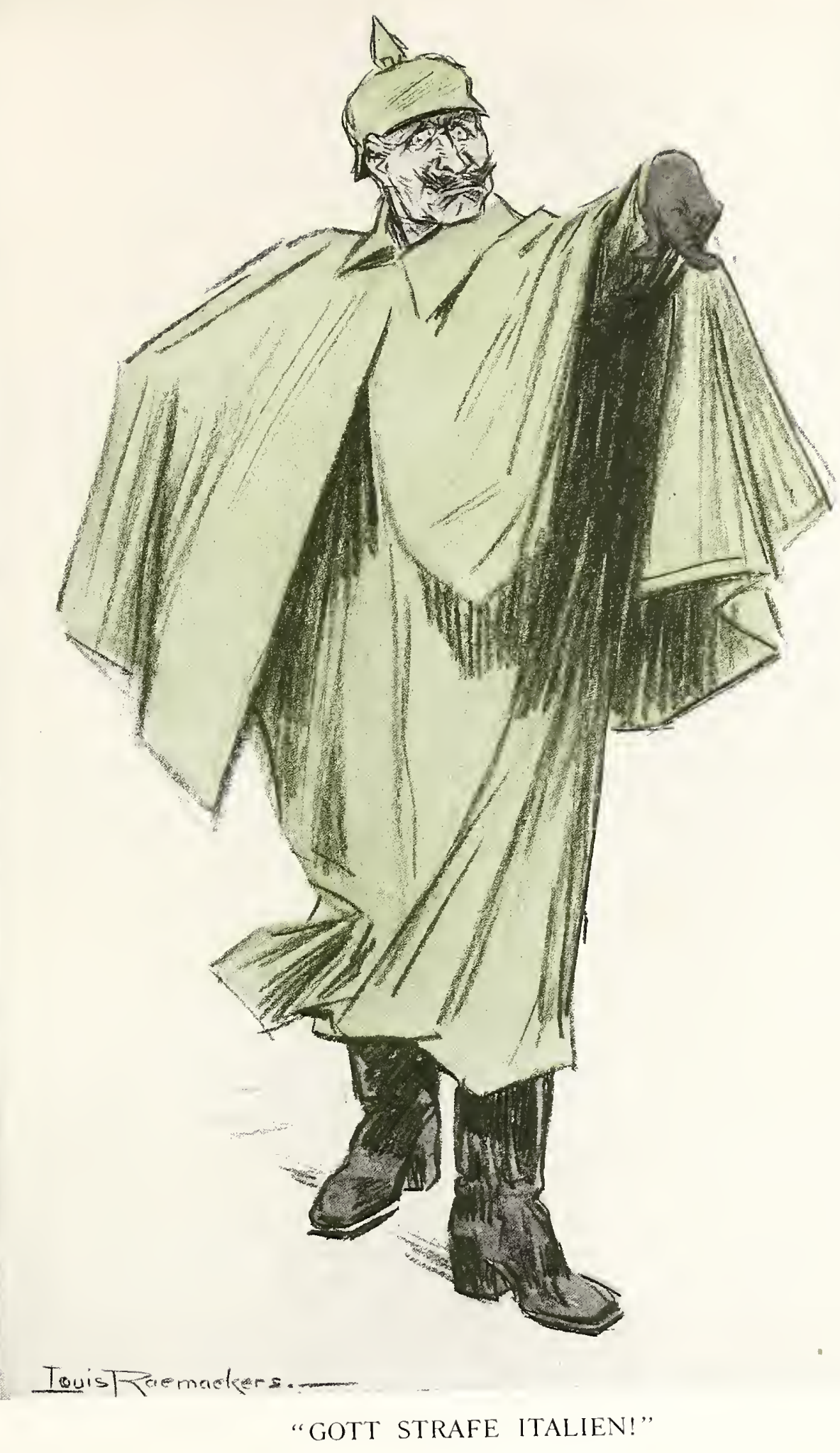




\section{Serbia}

ERBIA has suffered the fate of Belgium. Germany and Austria, with Bulgaria's aid, have plunged another little country "in blood and destruction." Another "bleeding piece of earth" bears witness to the recrudescence of the ancient barbarism of the Huns. Serbia's wounds,

"Like dumb mouths,

Do ope their ruby lips,"

to beg for vengeance on "these butchers." Turkey, whom the artist portrays as a hound lapping up the victim's blood, is fated to share the punishment for the crime. But the prime instigator is the German Emperor, whose Chancellor, with bitter irony, claims for his master the title of protector of the small nationalities of Europe. Herr von Bethmann-Hollweg can on occasion affect the mincing accents of the wolf when that beast seeks to lull the cries of the lamb in its clutches. The German method of waging war has rendered "dreadful objects so familiar" that the essential brutality of the enemy's activities runs a risk of escaping at times the strenuous denunciation which Justice demands. But the searching pencil of Mr. Raemaekers brings home to every seeing eye the true and unvarying character of Teutonic "frightfulness." All instincts of humanity are cynically defied on the specious ground of military necessity. Mr. Raemaekers is at one with Milton in repudiating the worthless plea:

"So spake the fiend, and with necessity, The tyrant's plea, excused his devilish deeds." 


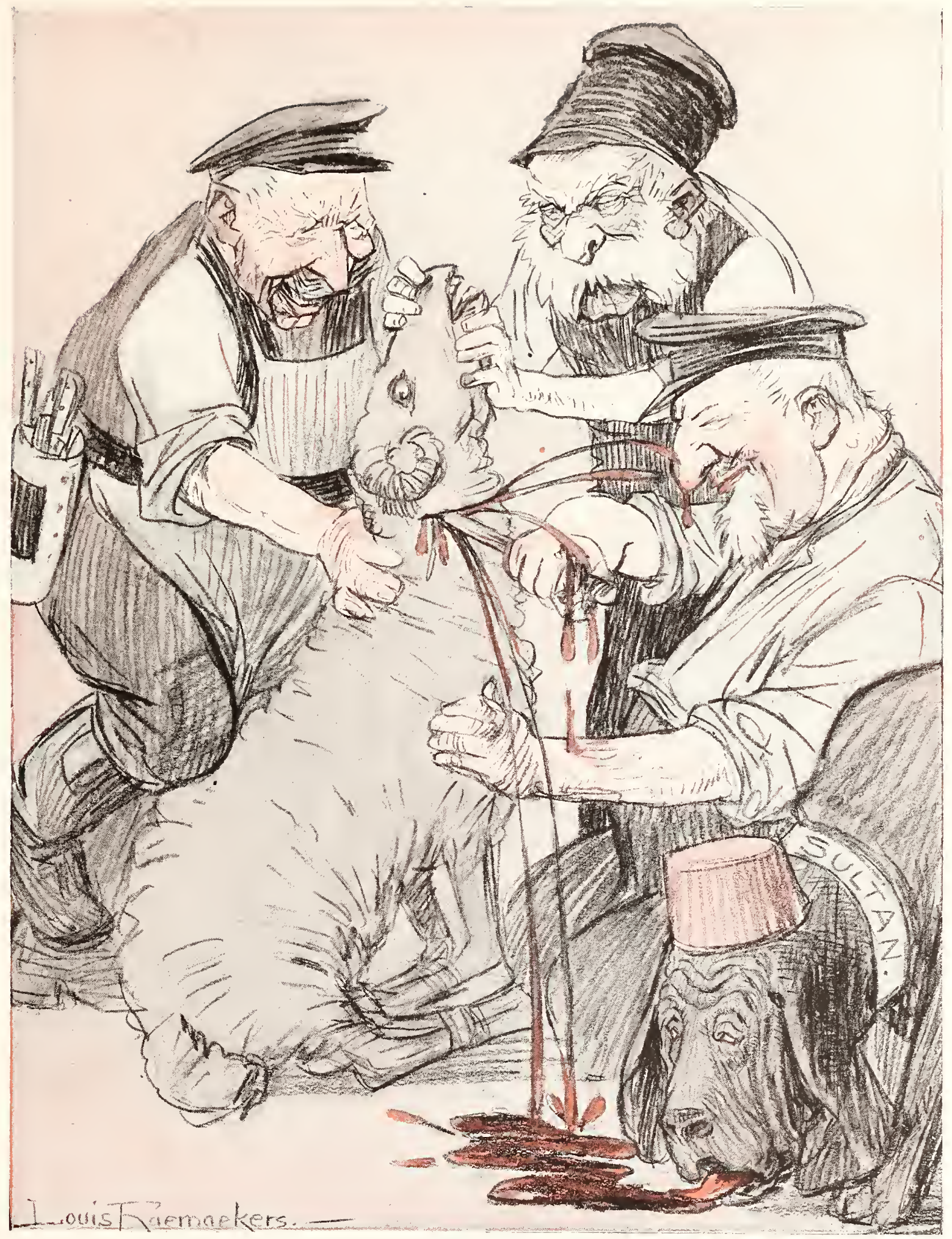

OCTOBER IN SERBIA

The Austro-German-Bulgarian attack on Serbia began in October, which in Holland is called the "butcher's month," as the cattle are then killed preparatory to the winter. 


\section{"Just a Moment-I'm Coming"}

$\mathrm{H}$

ERE is a drawing that ought to be circulated broadcast throughout Australia and New Zealand, that ought to hold a place

of honour on the walls of their public chambers; should hang in gilded frames in the houses of the rich; be pinned to the rough walls of frame-house and bark humpy in every corner of "The Outback." It should thrill the heart of every man, woman, and child Down Under with pride and thankfulness and satisfaction, should even bring soothing balm to the wounds of those who in the loss of their nearest and dearest have paid the highest and the deepest price for the flaming glory of the Anzacs in Gallipoli.

Here in the artist's pencil is a monument to those heroes greater than pinnacles of marble, of beaten brass and carven stone; a monument that has travelled over the world, has spoken to posterity more clearly, more convincingly, and more rememberingly than ever written or word-of-mouth speech could do. It is to the everlasting honour of the people of the Anzacs that they refrained from echoing the idle tales which ran whispering in England that the Dardanelles campaign was a cruel blunder, that the blood of the Anzacs' bravest and best had been uselessly spilt, that their splendid young lives had been an empty sacrifice to the demons of Incompetence and Inefficiency. To those in Australia who in their hearts may feel that shreds of truth were woven in the rumours - that the Anzacs were spent on a forlorn hope, were wasted on a task foredoomed to failurelet this simple drawing bring the comfort of the truth.

The artist has seen deeper and further than most. The Turkish armies held from pouring on Russia and Serbia, from thumping down the scales of neutrality in Greece and Roumania perhaps, from massing their troops with the Central Powers; the Kaiser chained on the East and West for the critical months when men and munitions were desperately lacking to the Allies, when the extra weight of the Turks might have freed the Kaiser's power of fierce attack on East and West this is what we already know, what the artist here tells the wide world of the part played by the heroes of the Dardanelles. In face of this, who dare hint they suffered and died in vain?

BOYD CABLE. 


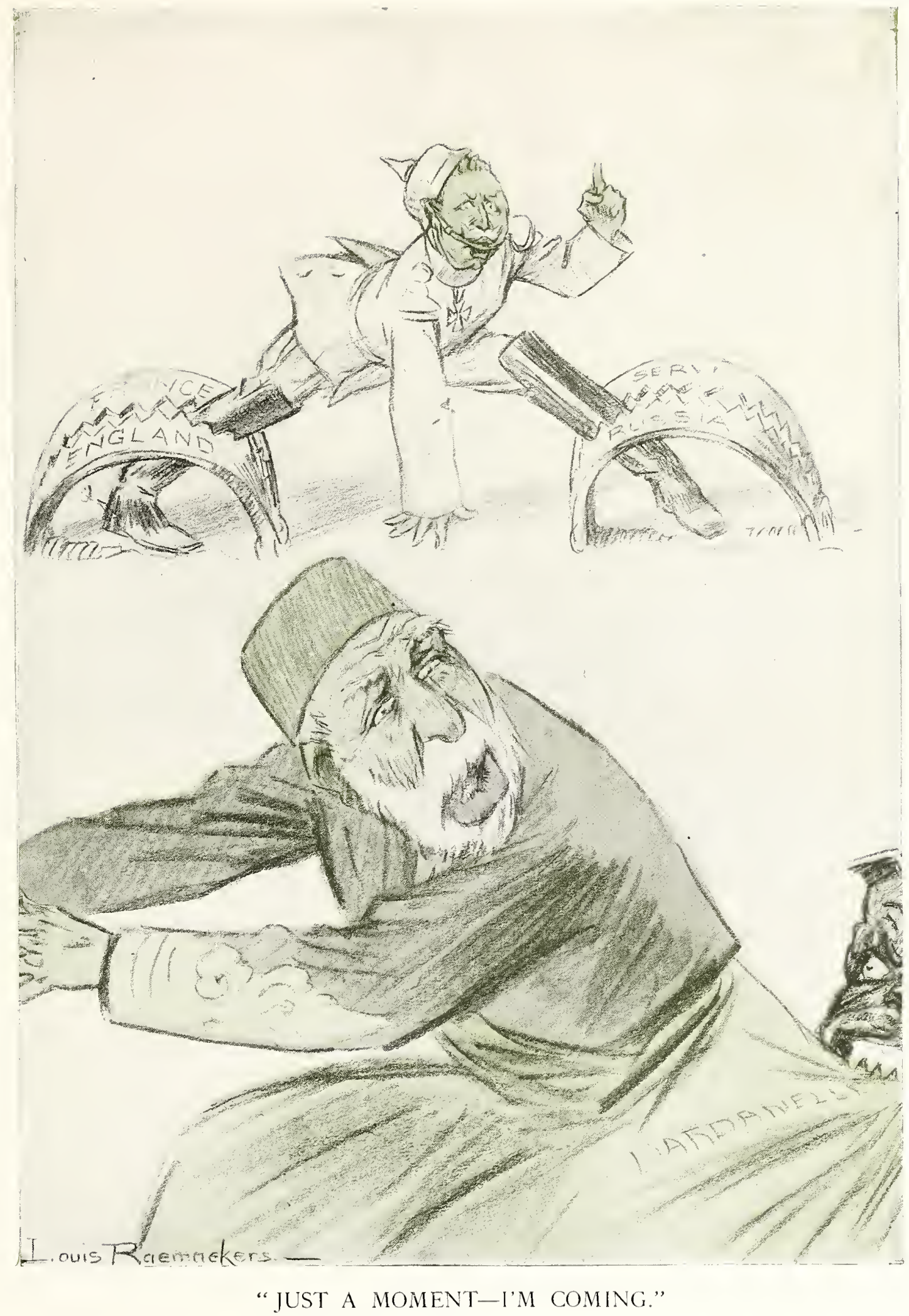




\section{The Holy War}

S URELY the artist when he drew this was endowed with the wisdom of the seer, the vision of the prophet. For it was drawn before the days in which I write, before the Russian giant had proved his greatness on the body of the Turk, before the bludgeon-strokes in the Caucasus, the heart-thrust of Erzerum, the torrent of pursuit of the broken Turks to Mush and Trebizond.

We know-and I am grateful for the chance to voice our gratitude to him-the greatness of our Russian Ally. We remember the early days when the Kaiser's hosts were pouring in over France, and the Russian thrust into Galicia drew some of the overwhelming weight from the Western Front. We realize now the nobility of self-sacrifice that flung an army within reach of the jaws of destruction, that risked its annihilation to draw upon itself some of the sword-strokes that threatened to pierce to the heart of the West. Our national and natural instinct of admiration for a hard fighter, and still greater admiration for the apex of good sportmanship, for the friend or foe who can "take a licking," who is a "good loser," went out even more strongly to Russia in the dark days when, faced by an overwhelming weight of metal, she was forced and hammered and battered back, losing battle-line after battle-line, stronghold after stronghold, city after city; losing everything except heart and dogged punishmentenduring courage.

And how great the Russian truly is will surely be known presently to the Turk and to the masquerading false "Prophet of Allah."

"No one is great save Allah," says William, and even as the Turk spoke more truly than he knew in calling the Russian great, even as he was bitterly to realize the greatness, so in the fullness of time must William come to realize how great is the Allah of the Moslem, the Christian God Whom he has blasphemed, and in Whose name he and his people have perpetrated so many crimes and abominations.

BOYD CABLE. 


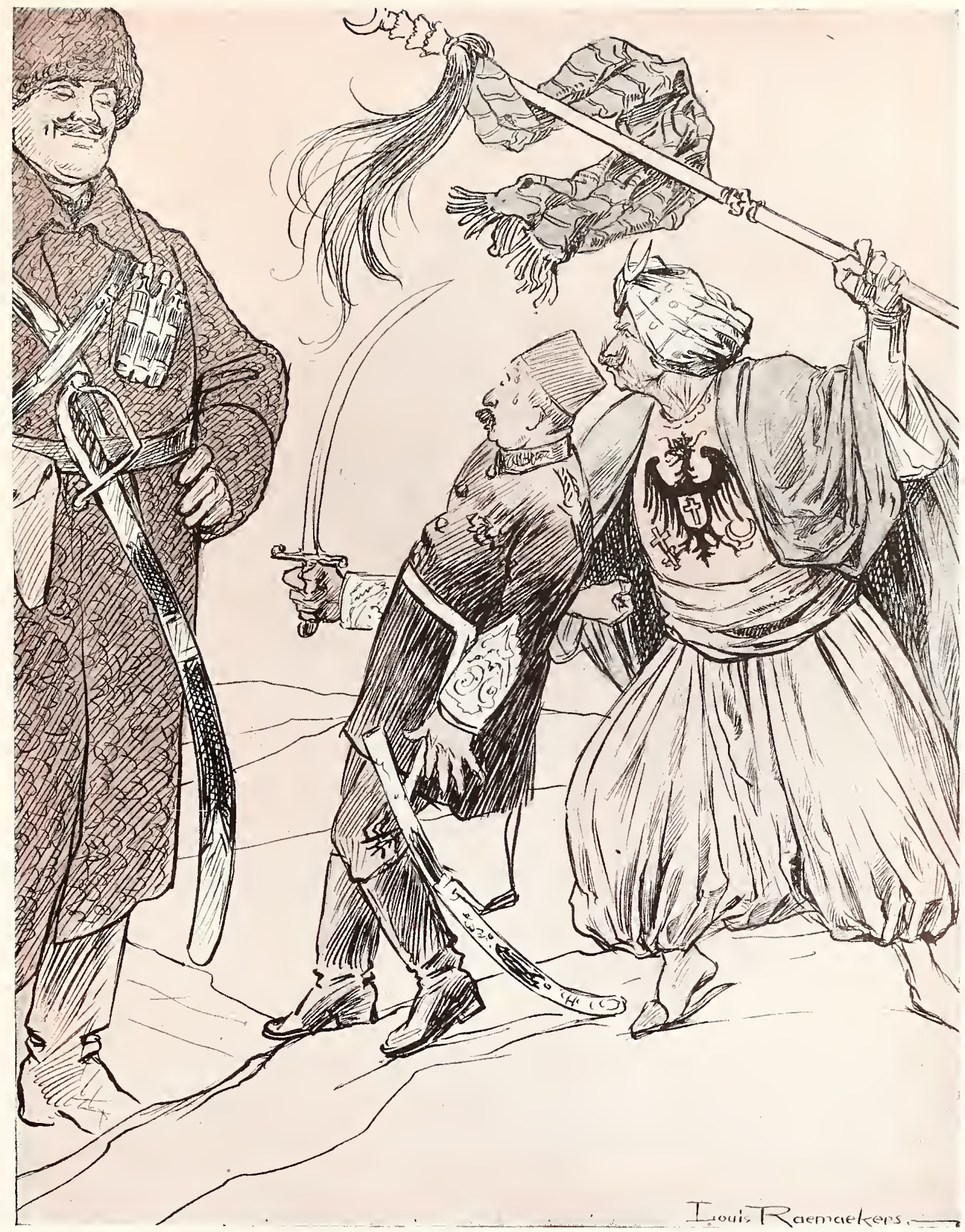

THE HOLY WAR

THE TURK: "But he is so great."

William : "No one is great, save Allah, and I am his prophet." 


\section{"Gott Mit Uns"}

$\mathrm{W}$

HEN we consider the public utterances of the German clergy, we can very easily substitute for their symbol of Christian faith this malignant, grotesque, and inhuman monster of Louis Raemaekers. Indeed, our inclination is to thrust the green demon himself into the pulpit of the Fatherland; for his wrinkled skull could hatch and his evil mouth utter no more diabolic sentiments than those recorded and applauded from Lutheran Leipsic, or from the University and the chief Protestant pulpit in Berlin.

Such sermons are a part of that national débâcle of reasoning faculty which is the price intellectual Germany has paid for the surrender of her soul to Prussia.

An example or two may be cited from the outrageous mass.

Professor Rheinhold Seeby, who teaches theology at Berlin University, has described his nation's achievements in Belgium and Serbia as a work of charity, since Germany punishes other States for their good and out of love. Pastor Philippi, also of Berlin, has said that, as God allowed His only Son to be crucified, that His scheme of redemption might be accomplished, so Germany, God with her, must crucify humanity in order that its ultimate salvation may be secured; and the Teutonic nation has been chosen to perform this task, because Germany alone is pure and, therefore, a fitting instrument for the Divine Hand. Satan, who has returned to earth in the shape of England, must be utterly destroyed, while the immoral friends and allies of Satan are called to share his fate. Thus evil will be swept off the earth and the German Empire henceforth stand supreme protector of the new kingdom of righteousness. Pastor Zoebel has ordered no compromise with hell; directed his flock to be pleased at the sufferings of the enemy; and bade them rejoice when thousands of the non-elect are sent to the bottom of the sea.

Yes, we will give the green devil his robe and bands until Germany is in her strait-jacket; after which experience, her conceptions of a Supreme Being and her own relation thereto may become modified.

EDEN PHILLPOTTS. 


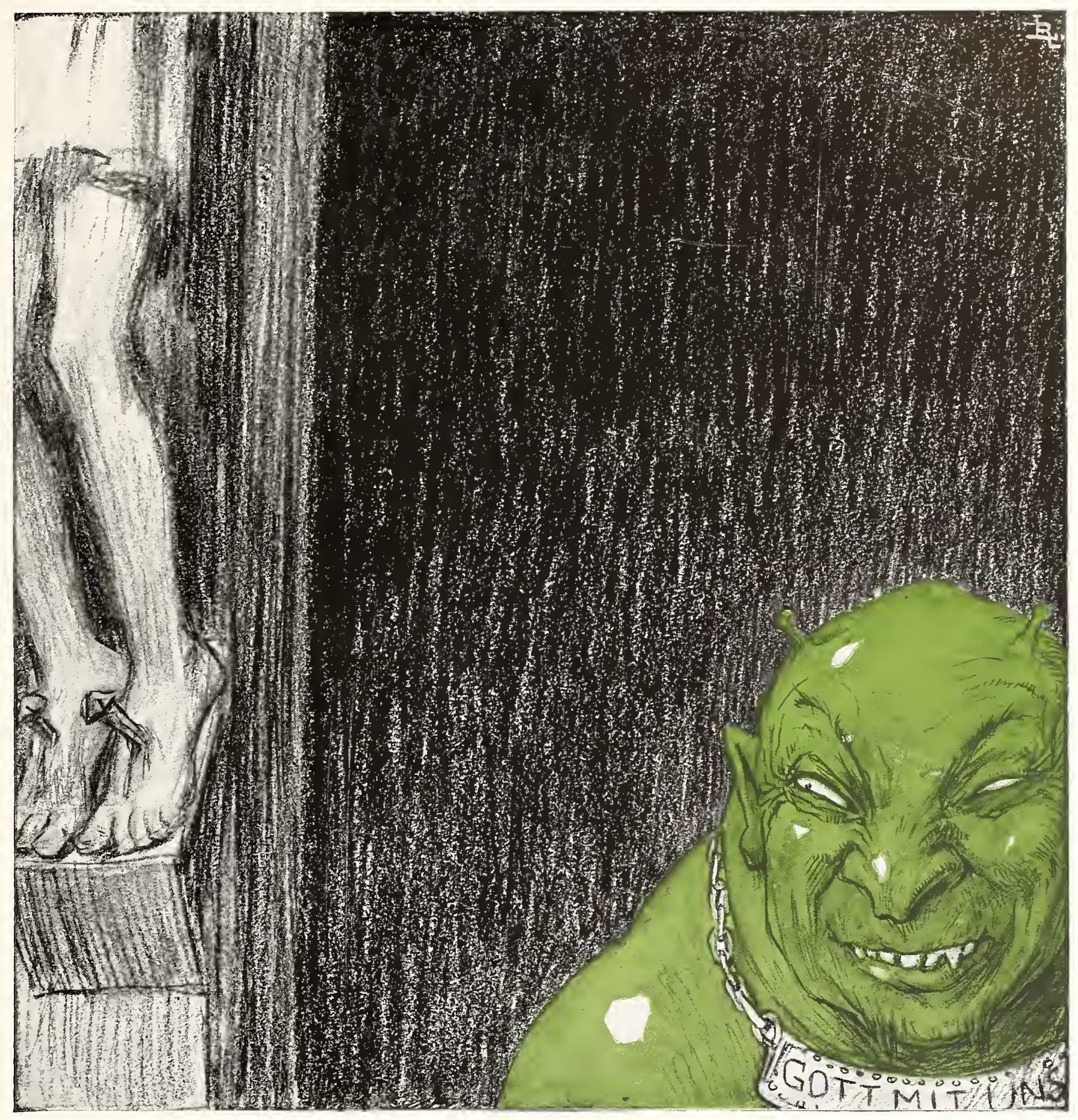

"GOTT MIT UNS" 


\section{The Widows of Belgium}

$\mathrm{T}$

HIS deeply pathetic picture evokes the memory of many sad and patient faces which we have seen during the last eighteen months. It is the women, after all-wives, mothers, sisters, and daughters - who have the heaviest load to bear in war-time.

The courage and heroism which they have shown are an honour to human nature. The world is richer for it; and the sacrifices which they have bravely faced and nobly borne may have a greater effect in convincing mankind of the wickedness and folly of aggressive militarism than all the eloquence of peace advocates.

We must not forget that the war has made about six German widows for every one in our country. With these we have no quarrel; we know that family affection is strong in Germany, and we are sorry for them. They, like our own suffering women, are the victims of a barbarous ideal of national glory, and a worse than barbarous perversion of patriotism, which in our opponents has become a kind of moral insanity.

These pictures will remain long after the war-passion has subsided. They will do their part in preventing a recrudescence of it. Who that has ever clamoured for war can face the unspoken reproach in these pitiful eyes? Who can think unmoved of the happy romance of wedded love, so early and so sadly terminated?

THE DEAN OF ST. PAUL'S. 


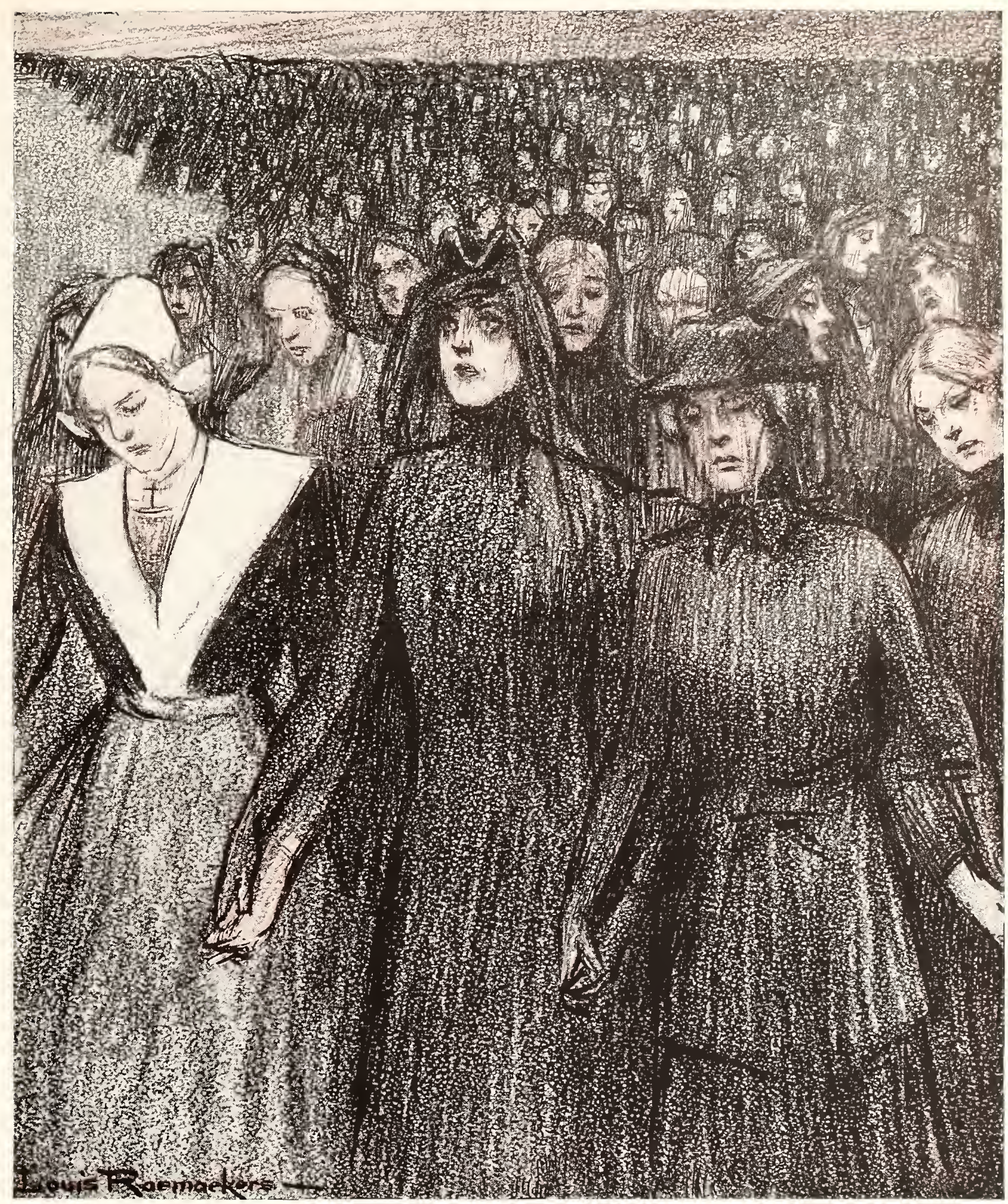

THE WIDOWS OF BELGIUM 


\section{The Harvest Is Ripe}

$7 \mathrm{HE}$ artist spreads before you a view such as you would have on the great wheat-growing plains of Hungary, or on the level plateau of Asiatic Turkey-the vast, unending, monotonous, undivided field of corn. In the background the view is interrupted by two villages from which great clouds of flame and smoke are risingthey are both on fire-and as you look closer at the harvest you see that, instead of wheat, it consists of endless regiments of marching soldiers.

"The harvest is plentiful, but the labourers are few": here is only one, but he is quite sufficient_- "the reaper whose name is Death," a skeleton over whose bones the peasant's dress - a shirt and a pair of ragged trousers-hangs loose. The shirt-sleeves of the skeleton are turned well up, as if for more active exertion, as he grasps the two holds of the huge scythe with which he is sweeping down the harvest.

This is not war of the old type, with its opportunities for chivalry, its glories, and its pride of manly strength: The German development of war has made it into a mere exercise in killing, a business of slaughter. Which side can kill most, and itself outlast the other? When one reads the calculations by which careful statisticians demonstrate that in the first seventeen months of the war Germany alone lost over a million of men killed in battle, one feels that this cartoon is not exaggerated. It is the bare truth.

The ease with which the giant figure of Death mows down the harvest of tiny men corresponds, in fact, to the million of German dead, probably as many among the Russians, to which must be added the losses among the Austrians, the French, the British, the Belgians, Italians, Serbs, Turks, and Montenegrins. The appalling total is this vast harvest which covers the plain.

WILLIAM MITCHELL RAMSAY. 


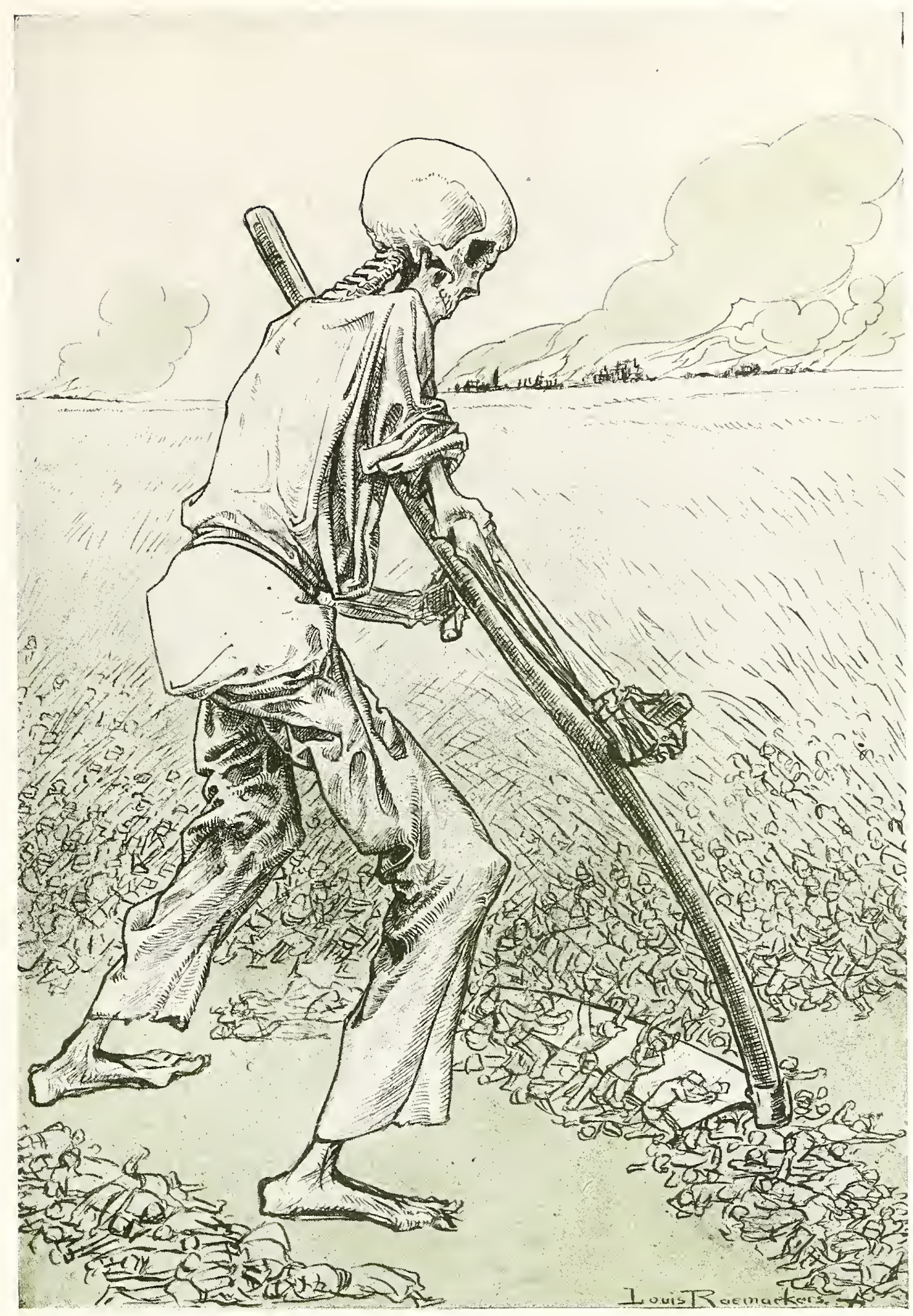

THE HARVEST IS RIPE 


\section{"Unmasked"}

HEE "Yellow Book," it may be remembered, was the official publication of some of the details of atrocities committed by the Huns on the defenceless women and children of ravished Belgium. It told in cold and unimpassioned sentences, in plain and simple words more terrible than the most fervid outpourings of patriot or humanitarian, the tale of brutalities, of cold-blooded crimes, of murders and rape and mental and physical tortures beyond the capabilities or the imaginings of savages, possible only in their refinements of cruelty to the civilized apostles of Kultur. There are many men in the trenches of the Allies to-day who will say that the German soldier is a brave man, that he must be brave to advance to the slaughter of the massed attack, to hold to his trenches under the horrible punishment of heavy artillery fire.

As a nation we are always ready to admit and to admire physical courage, and if Germany had fought a "clean fight," had "played the game," starkly and straightly, against our fighting men, we could--and our fighting men especially could, and I believe would-have helped her to her feet and shaken hands honestly with her after she was beaten. But with such a brute beast as the unmasking of the "Yellow Book" has revealed Germany to be we can never feel friendship, admiration, or respect.

The German is a "dirty fighter," and to the British soldier that alone puts him beyond the pale. He has outraged all the rules and the instincts of chivalry. His bravery in battle is the bravery of a ravening wolf, of a blood-drunk savage animal. It is only left to the Allies to treat him as such, to thrash him by brute force, and then to clip his teeth and talons and by treaty and agreement amongst themselves to keep him chained and caged beyond the possibility of another outbreak.

BOYD CABLE. 


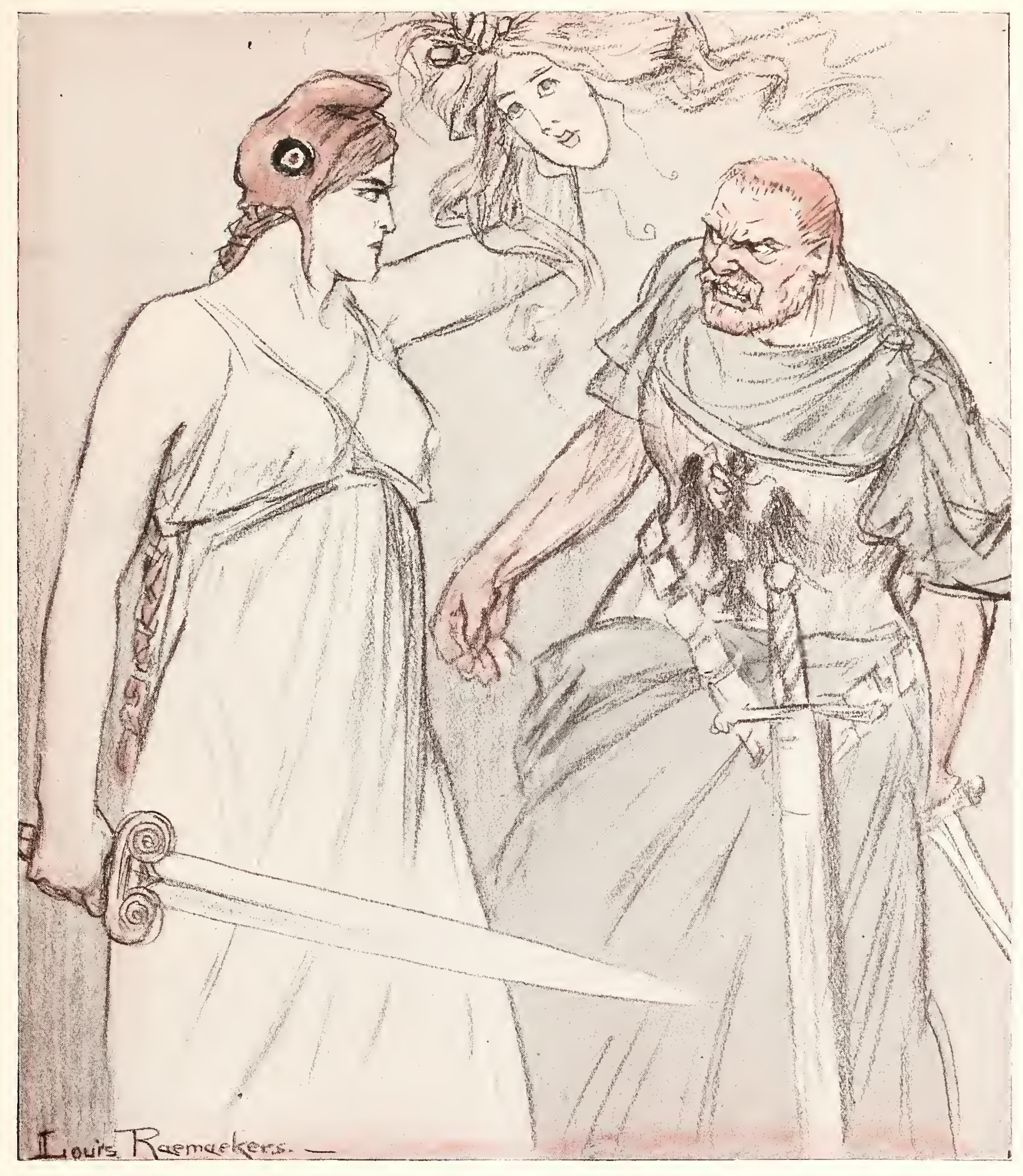

UNMASKED

The Yellow Book 


\section{The Great Surprise}

T $N$ THE note to another picture I have remarked on the farcical hypocrisy of the German Emperor in presenting himself, as he so often does, as the High Priest of several different religions at the same time. They are nearly all of them religions with which he would have no sort of concern, even if his religious pose were as real as it is artificial.

Being in fact the ruler and representative of a country which alone among European countries builds with complete security upon the conviction that all Christianity is dead, he can only be, even in theory, the prince of an extreme Protestant State. Long before the War it was common for the best caricaturists of Europe, and even of Germany, to make particular fun of these preposterous temporary Papacies in which the Kaiser parades himself as if for a fancydress ball; and in the accompanying picture Mr. Raemaekers has returned more or less to this old pantomimic line of satire.

The cartoon recalls some of those more good-humoured, but perhaps equally contemptuous, sketches in which the draughtsmen of the French comic papers used to take a particular delight; which made a whole comic Bible out of the Kaiser's adventures during his visit to Palestine. Here he appears as Moses, and the Red Sea has been dried up to permit the passage of himself and his people.

It would certainly be very satisfactory for German world-politics if the sea could be dried up everywhere; but it is unlikely that the incident will occur, especially in that neighbourhood. It will be long before a German army is as safe in the Suez Canal as a German Navy in the Kiel Canal; and the higher critics of Germany will have no difficulty in proving, in the Kiel Canal at all events, that the safety is due to human and not to divine wisdom.

G. K. CHESTERTON. 


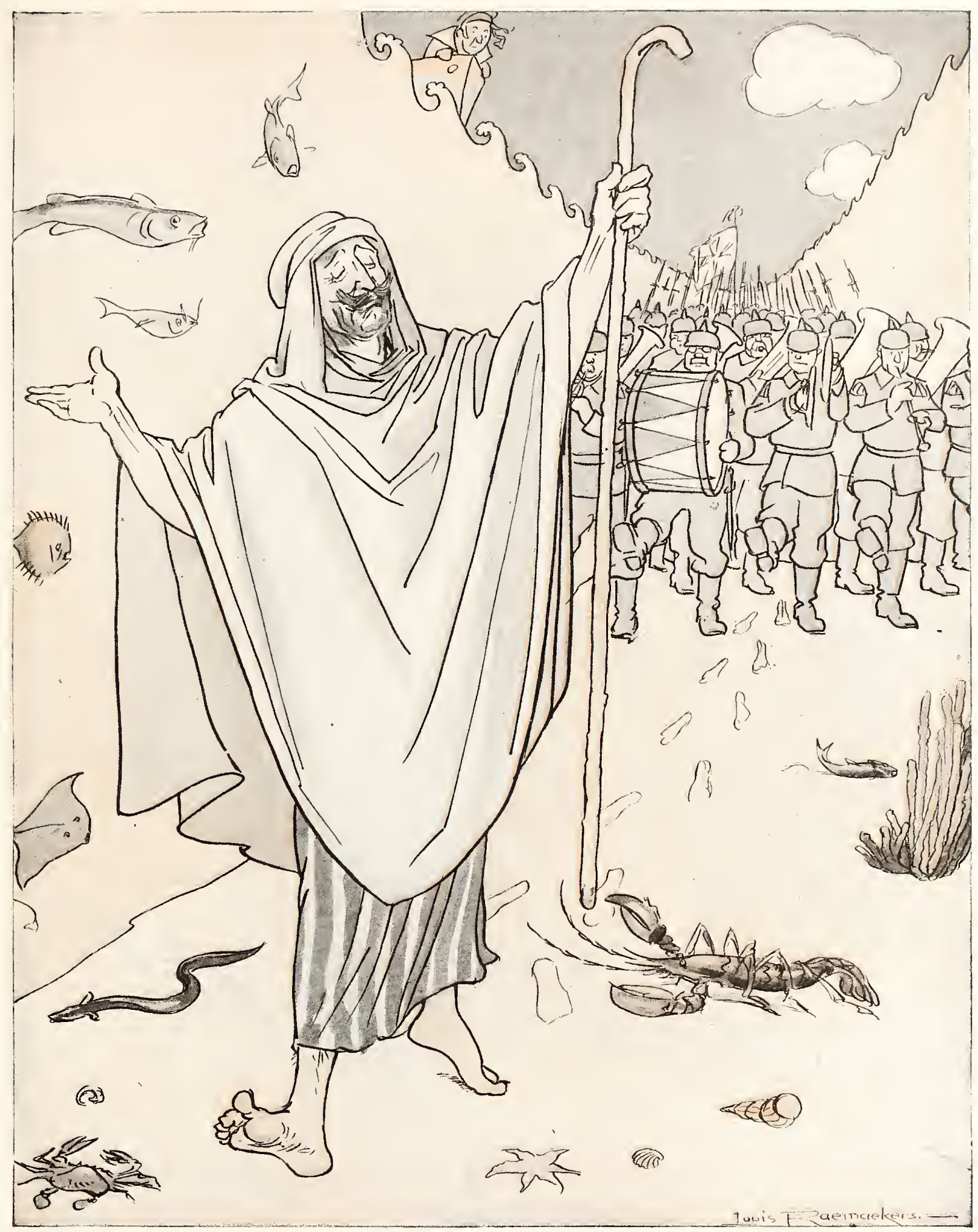

THE GREAT SURPRISE

Moses II leads his chosen people through the Red Sea to the promised (Eng)land. 


\section{Thou Art the Man!}

$\mathrm{T}$

HE Man of Sorrows is flogged, and thorn-crowned, and crucified, and pierced afresh, by this other man of sorrows, who has brought greater bitterness and woe on earth than any other of all time. And in his soul-for soul he must have, though small sign of it is evidenced-he knows it. Deceive his dupes as he may-for a time-his own soul must be a very hell of broken hopes, disappointed ambitions, shattered pride, and the hideous knowledge of the holocaust of human life he has deliberately sacrificed to these heathen gods of his. No poorest man on earth would change places with this man-thatmight-have-been, for his time draws nigh and his end is perdition.

Let That Other speak:

"Their souls are Mine.

Their lives were in thy hand;-

Of thee I do require them!

"The fetor of thy grim burnt-offerings

Comes up to Me in clouds of bitterness.

Thy fell undoings crucify afresh

Thy Lord - who died alike for these and thee.

Thy works are Death:- thy spear is in My side,-

O man! O man!-was it for this I died?

Was it for this?-

A valiant people harried to the void,-

Their fruitful fields a burnt-out wilderness, -

Their prosperous country ravelled into waste,-

Their smiling land a vast red sepulchre,---

- Thy work!

"Thou art the man! The scales were in thy hand.

For this vast wrong I hold thy soul in fee.

Seek not a scapegoat for thy righteous due,

Nor hope to void thy countability.

Until thou purge thy pride and turn to Me,-

As thou hast done, so be it unto thee!" 


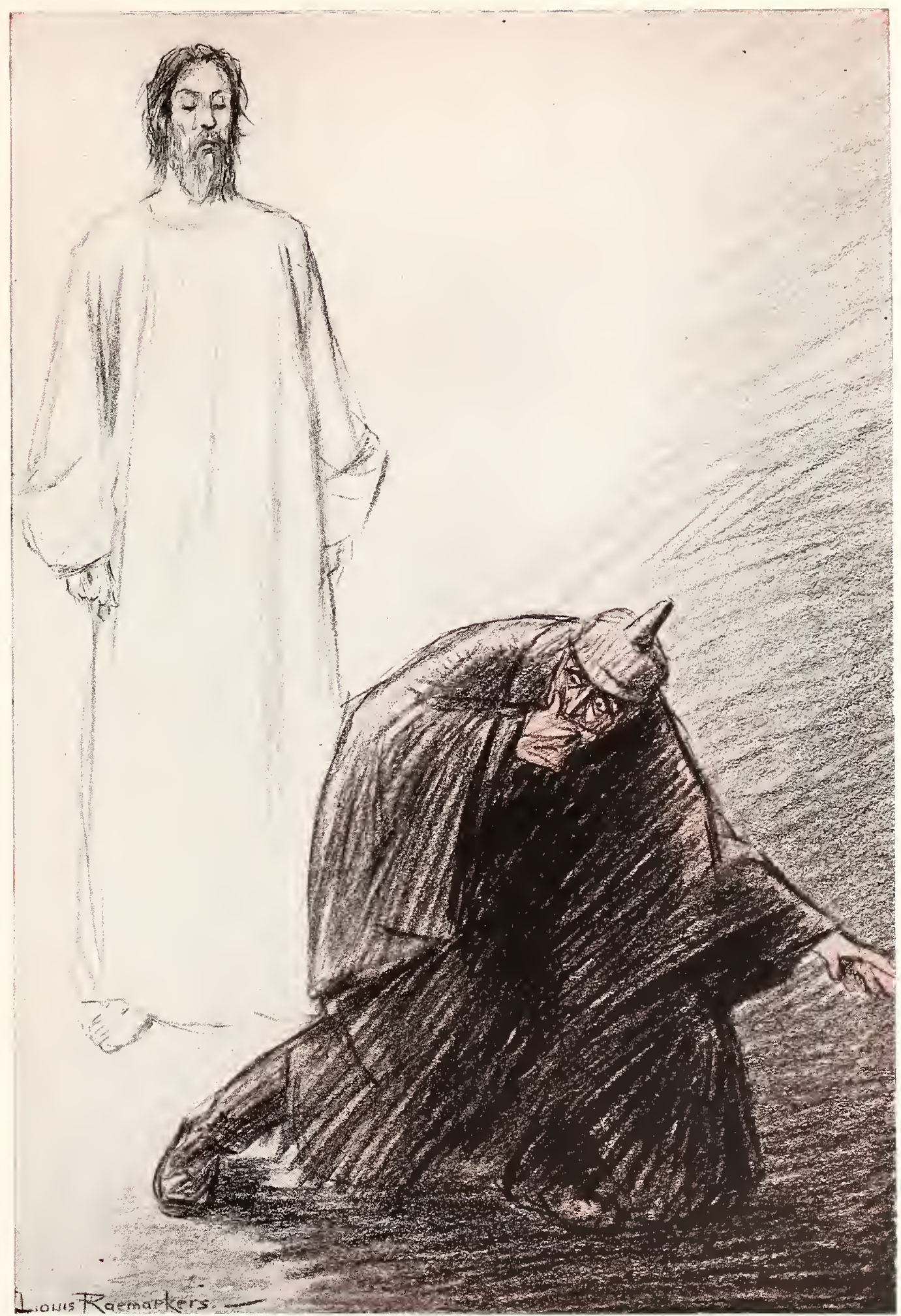

THOU ART THE MAN

"We wage war on Divine principles." 


\section{Sympathy}

$\mathrm{T}$ HE cartoon requires no words to tell the story. It holds chapter upon chapter of tragedy. "I will send you to Germany after your father!" Where is the boy's father in Germany? In a prison? Mending roads? Lying maimed and broken in a rude hospital? Digging graves for comrades about to be shot? Or, more likely still, in a rough unknown stranger's grave? Was the father dragged from his home at Louvain, or Tirlemont, or Visé, or one of the dozen other scenes of outrage and murder-a harmless, hard-working citizendragged from his hiding-place and made to suffer "exemplary justice" for having "opposed the Kaiser's might," but in reality because he was a Belgian, for whose nasty breed there must be demonstrations of Germany's frightfulness pour encourager les autres?

And the child's mother and sisters-what of them? He is dejected, but not broken. There is dignity in the boy's defiant pose. The scene has, perhaps, been enacted hundreds of times in the cities of Belgium, where poignant grief has come to a nation which dared to be itself.

Follow this boy through life and observe the stamp of deep resolve on his character. Though he be sent "to Germany after your father," though he be for a generation under the German jack-boot, his spirit will sustain him against the conqueror and will triumph in the end.

\section{RALPH D. BLUMENFELD.}



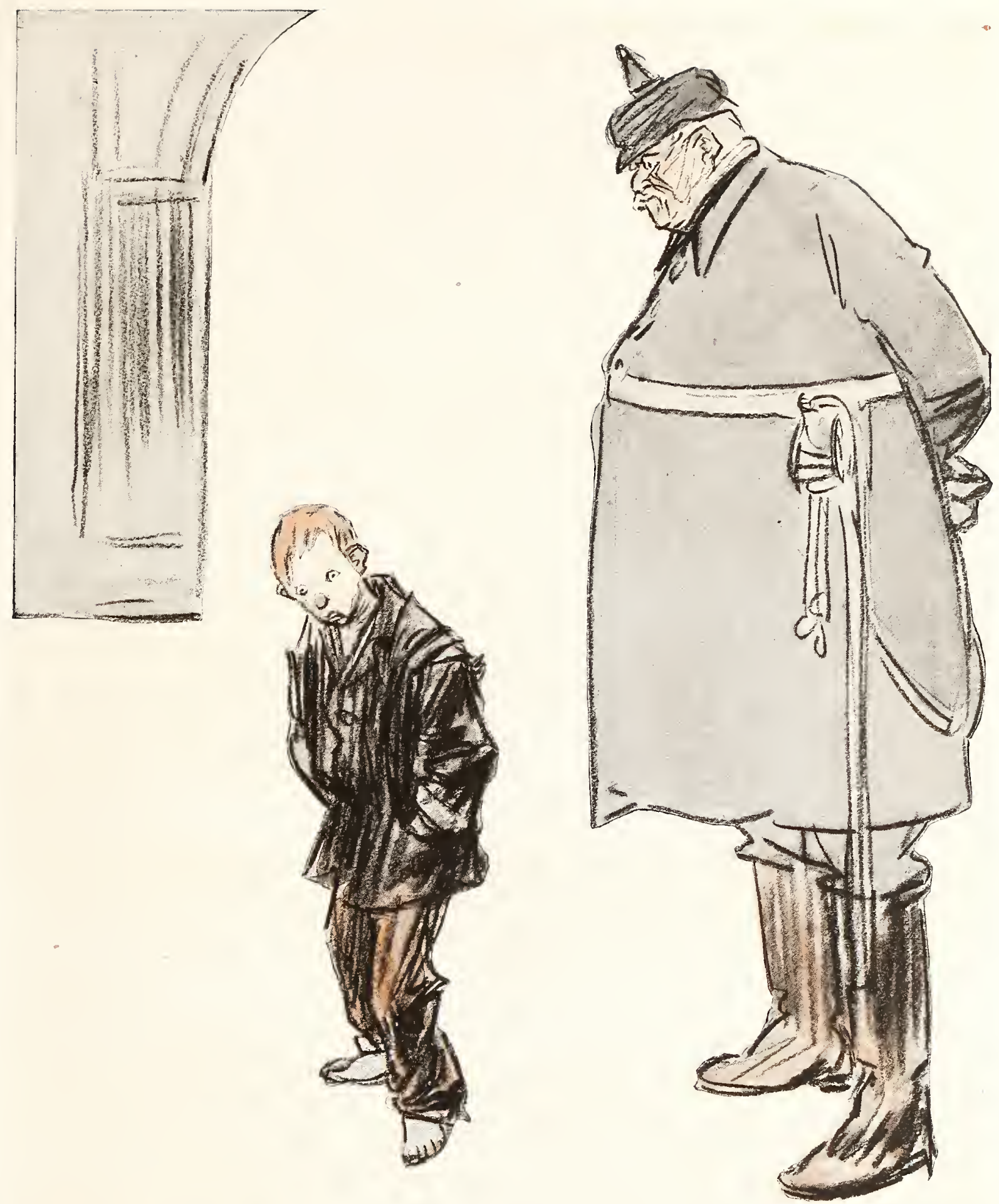

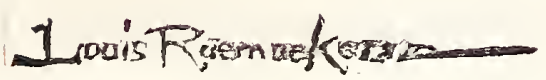

SYMPATHY

"If I find you again looking so sad, I'll send you to Germany after your father." 


\section{The Refugees}

$\mathrm{T}$ HE wonder is not that women went mad, but that there are left any sane civilians of the ravished districts of Belgium after all those infamies perpetrated under orders by the German troops after the first infuriating check of Liége and before the final turning of the German line at the battle of the Marne. We have supped full of horrors since, and by an insensible process grown something callous. But we never came near to realizing the Belgian agony, and Raemaekers does us service by helping to make us see it mirrored in the eyes of this poor raving girl. This indeed is a later incident, but will serve for reminder of the earlier worse.

It is really not well to forget. These were not the inevitable horrors of war, but a deliberately calculated effect. There seems no hope of the future of European civilization till the men responsible for such things are brought to realize that, to put it crudely and at its lowest, they don't pay.

What the attitude of Germany now is may be guessed from the blank refusal even of her bishops to sanction the investigation which Cardinal Mercier asks for. It is still the gentle wolf's theory that the truculent lamb was entirely to blame.

JOSEPH THORP. 


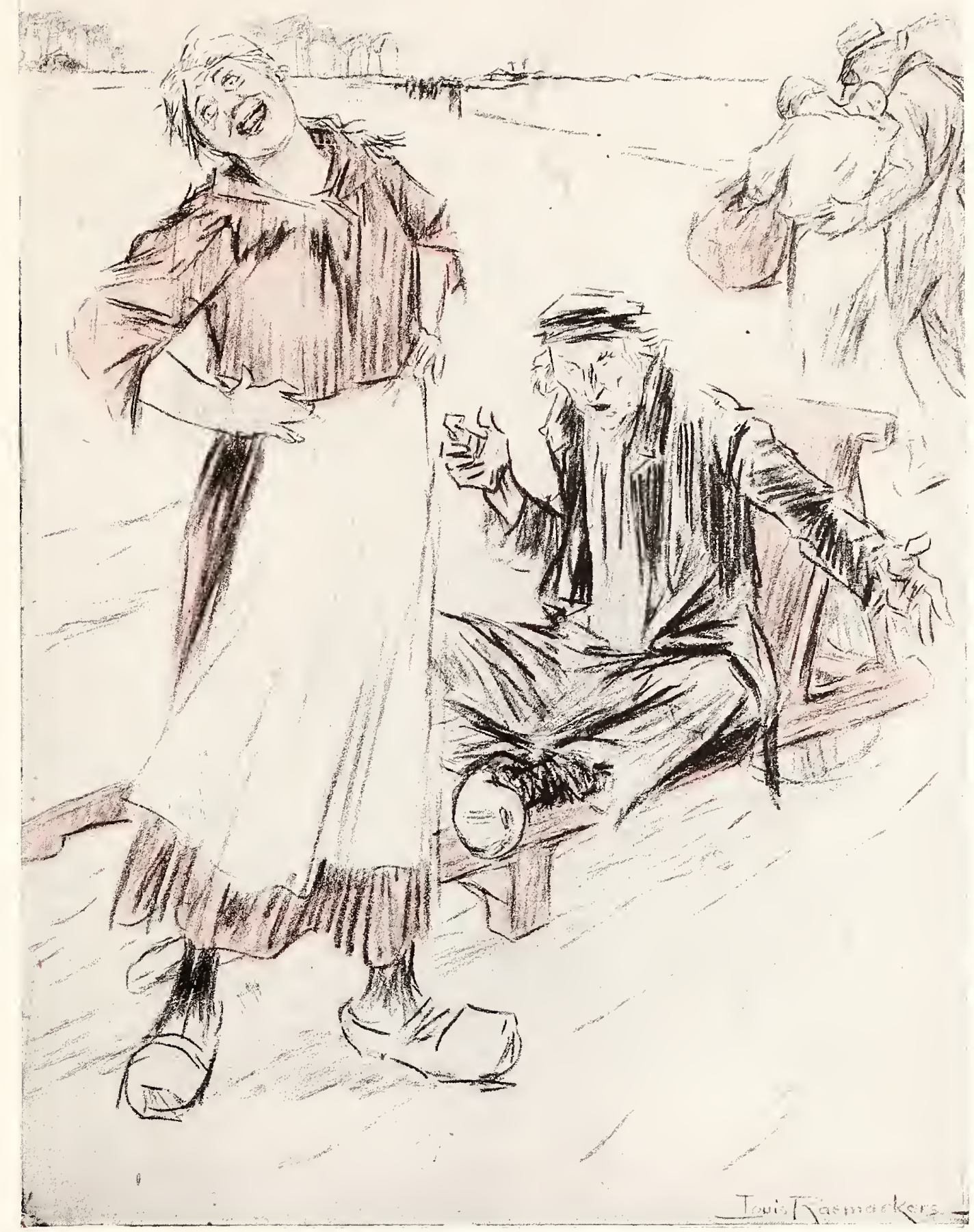

THE REFUGEES FROM GHEEL

Gheel has a model asylum for the insane. On the fall of Antwerp the inmates were conveyed across the frontier. The cartoon illustrates an incident where a woman, while wheeling a lunatic, herself developed insanity from the scenes she witnessed. 


\section{"The Junker"}

$\mathrm{T}$

HERE were few things that Junkerdom feared so much in modern Germany as the growth and effects of Socialism; and it is certain that the possible attitude of the German Socialists -who were thought by some writers to number somewhere in the neighbourhood of Lwo million - in regard to the War at its outset greatly exercised the minds of Junkerdom and the Chancellor. A few days after the declaration of War a well-known English Socialist said to us, "I believe that the Socialists will be strong enough greatly to handicap Germany in the carrying on of the War, and possibly, if she meets with reverses in the early stages, to bring about Peace before Christmas."

That was in August, 1914, and we are now well on in the Spring of 1916. We reminded the speaker that on a previous occasion, when Peace still hung in the balance, he had declared with equal conviction that there would be no Var because "the Socialists are now too strong in Germany not to exercise a preponderating restraining influence." He has proved wrong in both opinions. And one can well imagine that the Junker class admires Chancellor von Bethmann-Hollweg for the astute manner in which he has succeeded in shepherding the German Socialist sheep for the slaughter, and in muzzling their representatives in the Reichstag.

CLIVE HOLLAND. 


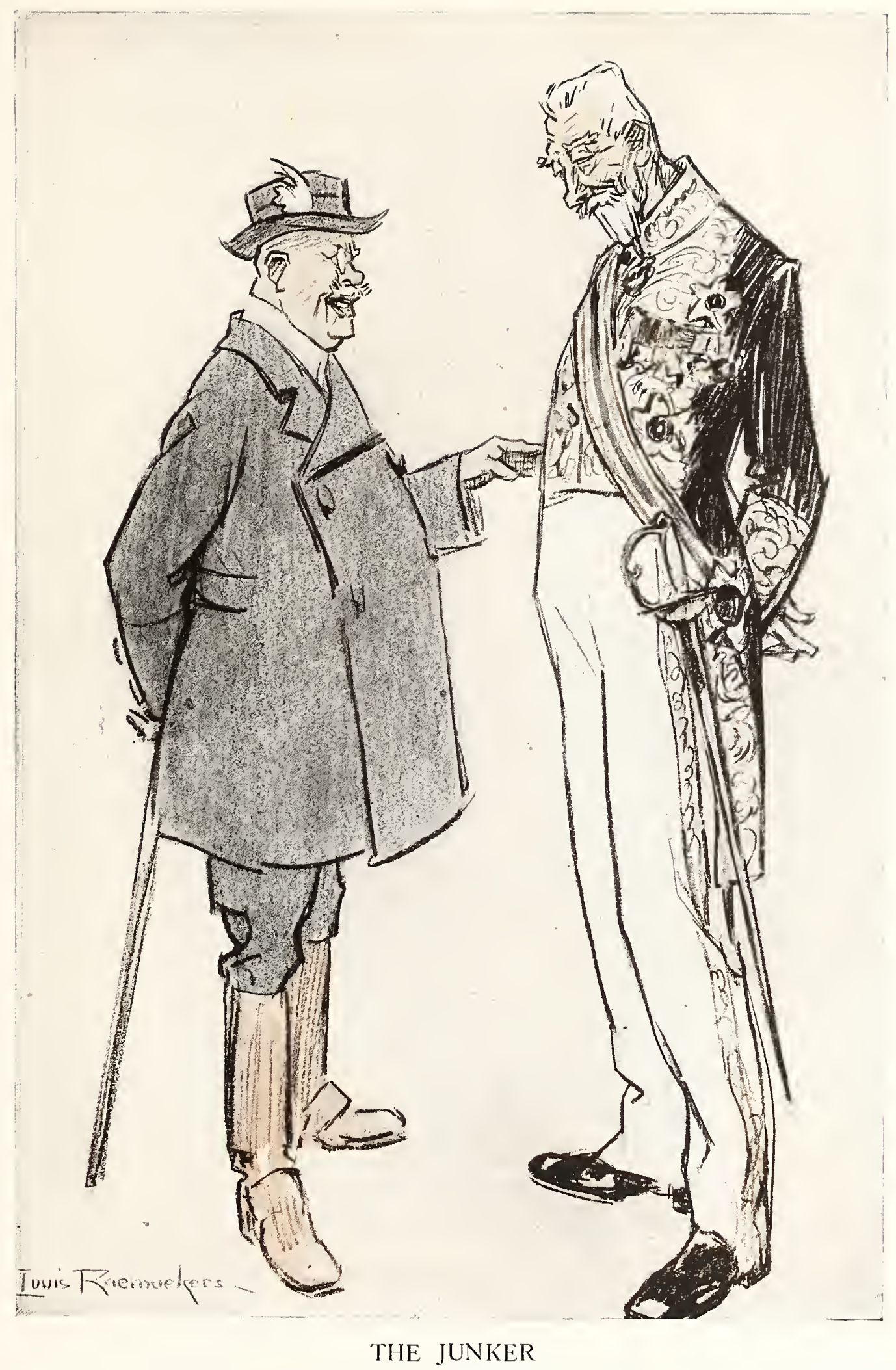

"What I have most admired in you, Bethmann, is that you have made Socialists our best supporters." 


\section{"Au Milieu De Fantômes Tristes Et Sans Nombre"}

7 IIERE is something daunting, even to the mind of one not guilty of war or of massacres, in the thought of multitudes: the multitude of the dead, of the living, of one generation of men since there have been men on earth. And war brings this horror to us daily, or rather nightly, because such great companies of men have suddenly died together, passing in comradeship and community from the known to the unknown. Yet dare we say "together?" The unparalleled solitariness and singleness of death is not altered by the general and simultaneous doom of battle.

And it is with the multitude, and all the ones in it, that the maker of war is in unconscious relation. He does not know their names, he does not know them by any kind of distinction, he knows them only by thousands. Yet every one with a separate life and separate death is in conscious relation with him, knows him for the tyrant who has taken his youth, his hope, his love, his fatherhood.

What a multitude to meet, whether in thought, in conscience, or in another world! We all, no doubt, try to make the thought of massacre less intolerable to our minds by telling ourselves that the sufferers suffer one by one, to each his own share, and not another's; that though the numbers may appeal, they do not make each man's part more terrible. But this is not much comfort. There is not, it is true, a sum of multiplication; but there is the sum of addition. And that addition-the multitude man by man-the War Lord has to reckon with: Frederick the Great with his men, Napoleon with his, the German Emperor with his - each one of the innumerable unknown knowing his destroyer.

ALICE MEYNELL. 


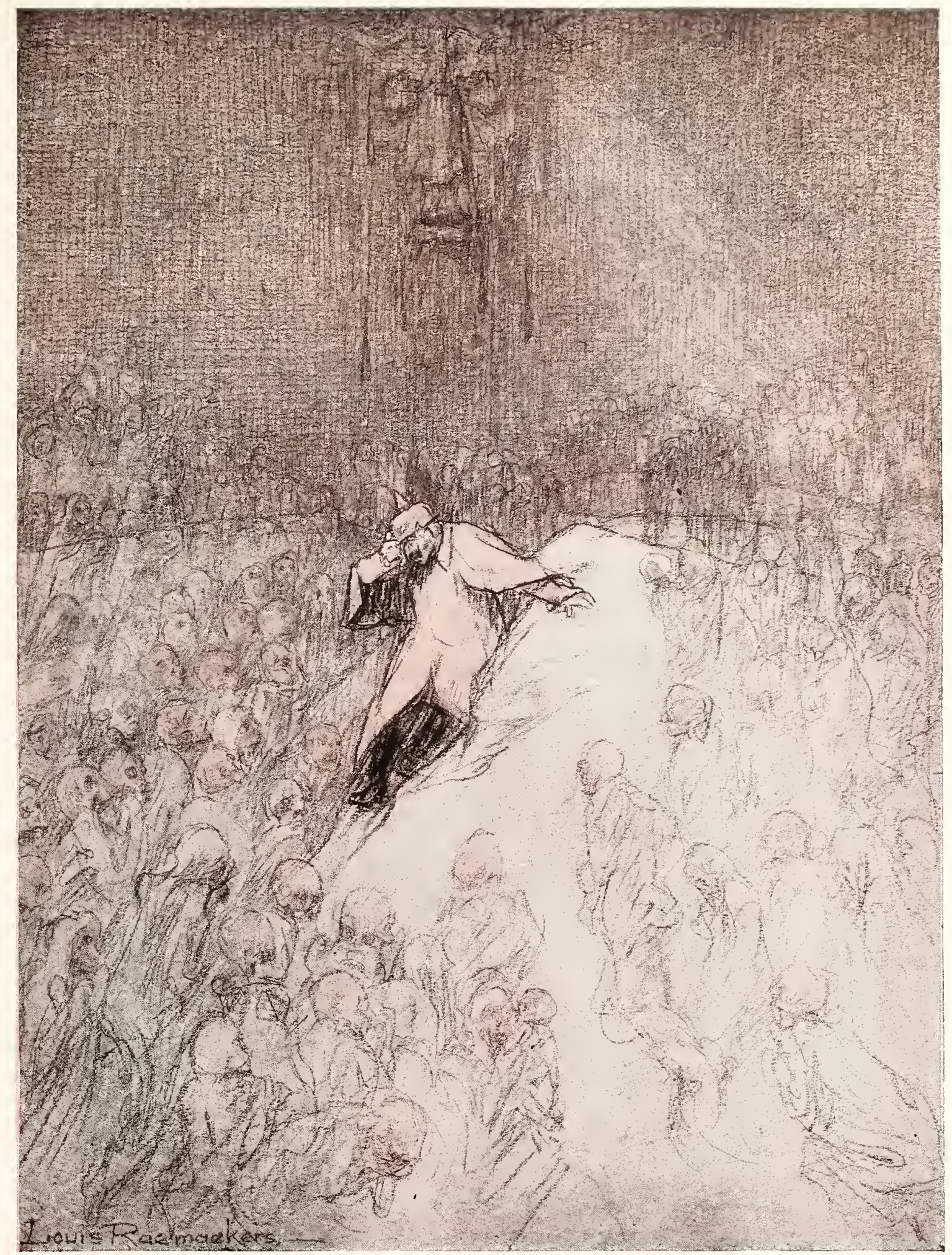

"Mais quand la voix de Dieu l'appela il se voyait seul sur la terre au milieu de fantômes tristes et sans nombre." 


\section{Bluebeard's Chamber}

$\mathrm{T}$ HE Committee of Enquiry, like another Portia, clothed in the ermine-trimmed robe of Justice and the Law, has unlocked with the key of Truth the door of the closed chamber. The key lies behind her inscribed in Dutch with the name that tells its nature. The Committee then pulls back the curtain, and reveals the horrors that are behind it. Before the curtain is fully drawn back, Enquiry sinks almost in collapse at the terrible sight that is disclosed. There hang to pegs on the wall the bodies of Bluebeard's victims, a woman, an old man, a priest, two boys, and a girl still half hidden behind the curtain. The blood that has trickled from them coagulates in pools on the ground.

Bluebeard himself comes suddenly: he hurries down the steps brandishing his curved sword, a big, burly figure, with square, thick beard, and streaming whiskers, wearing a Prussian helmet, his mouth open to utter a roar of rage and fury. The hatred and scorn with which the artist inspires his pictures of Prussia are inexhaustible in their variety: Prussia is barbarism attempting to trample on law and education, brutality beating down humanity, a grim figure, the incarnation of "frightfulness." I can imagine the feelings with which all Germans must regard the picture that the Dutch artist always gives of their country, if they regard Prussia as their country. "For every cartoon of Raemackers," said a German newspaper, "the payment will be exacted in full, when the reckoning is made up." To this painter the Prussian ruling power is incapable of understanding what nobility of nature means. He can practise on and take advantage of the vices and weaknesses of his enemies; he can buy the services of many among them, and have all the worser people in his fee as his servants and agents; but he is always foiled, because he forgets that some men cannot be bought, and that these men will steel their fellow-countrymen's minds to resist tyranny to the last. The mass of men can be led either to evil or to good.

The Prussian military system assumes the former as certain, and is well skilled in the way. But there is the latter way, too, which Prussia never knew and never takes into account as a possibility; and men as a whole prefer the way to good before the way to evil, when both are fully explained and made clear. This saves men, and ruins Prussia.

WILLIAM MITCIELL RAMSAY. 


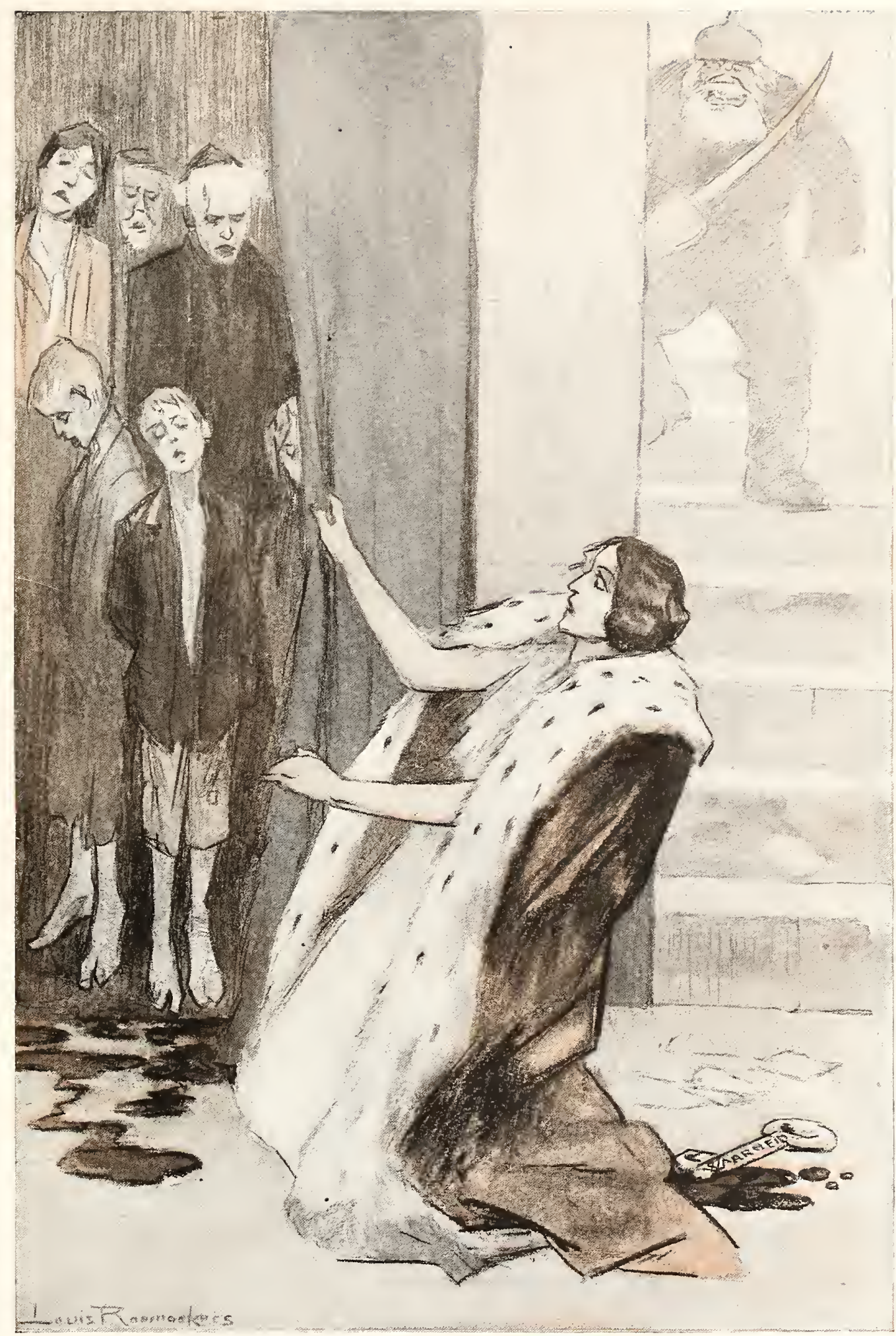

BLUEBEARD'S CHAMBER

The horrors perpetrated by the Germans were brought to light by the Belgian rommittee of Enquiry. 


\section{The Raid}

7 HE seaman of history is a chivalrous and romantic figure, a gallant and relentless fighter, a generous and a tender conqueror. In Codrington's first letter to his wife after the battle of Trafalgar, he tells her to send $£ 100$ to one of the French captains who goes to England from the battle as a prisoner of war. The British and French navies cherish a hundred memories of acts like these. If the German navy survives the war what memories will it have? It must search the gaols for the exemplars in peace of the acts that win them the Iron Cross in war.

Note in this drawing that the types selected are not in themselves base units of humanity. They have been made so by the beastly crimes superior orders have forced them to commit. But even this has not brought them so low but they wonder at the topsy-turvydom of war that brings them honour where poor Black Mary only got her deserts in gaol.

The crimes of the higher command have passed in Germany uncondemned and unbanned by cardinals and bishops. But the conscience of Germany cannot be wholly dead. Nor will six years only be the term of Germany's humiliation and remorse. The spotless white of the naval uniform, sullied and besmirched by those savage cruelties, cannot, any more than the German soul, be brought back "whiter than snow" by any bestowal of the Iron Cross. The effort to cleanse either would "the multitudinous seas incarnadine."

ARTHUR POLLEN. 


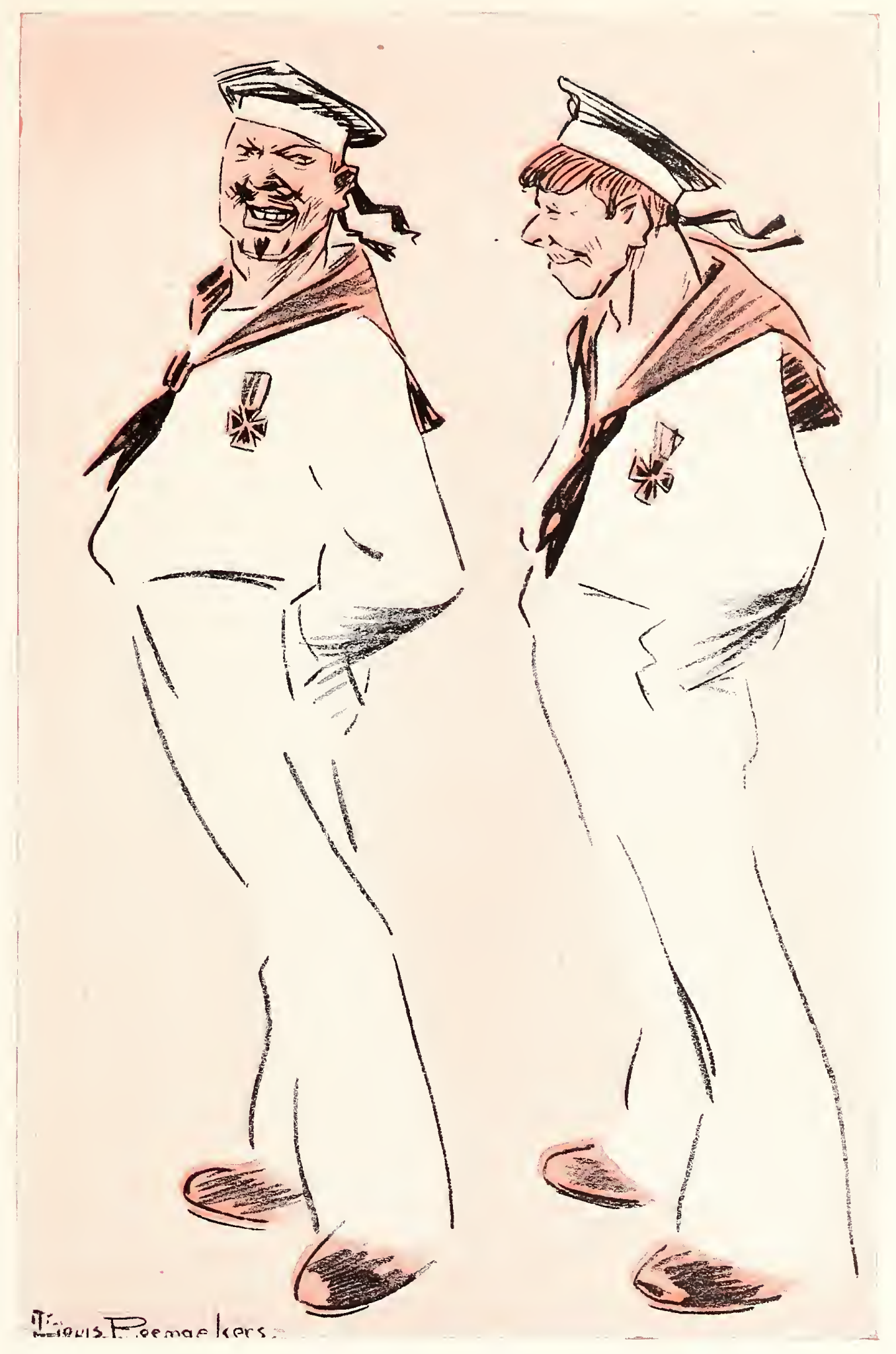

THE RAID

"Do you remember Black Mary of Hamburg?"

"Aye, well."

"She got six years for killing a child, whilst we get the Iron Cross for killing twenty at Hartlepool." 


\section{Better a Lising Dog Than a Dead Lion}

$\mathrm{H}^{\prime}$

ERE is the grim choice of alternatives presented to other nations by the creed of Deutschland über Alles - the cost of resistance and the reward of submission. On one side lies the man who has fought a good fight "for Freedom." He has lost his life but won an immortal memory inscribed upon the cross. The other has saved his life, and lo! it is a "dog's life." He is not even a well-treated dog. Harnessed, muzzled, chained, he crawls abjectly on hands and knees and drags painfully along the road, not only the cart, but his heavy master too.

In the Netherlands and other parts of the Continent, where dogs are used to pull little carts, the owner generally pulls too; it is a partnership in which the $\operatorname{dog}$ is treated as a friend and visibly enjoys doing his share. Partnership with Germany is another matter. The dog does all the work, the German takes his ease with his great feet planted on the submissive creature's back.

The belligerent nations have made their choice. Germany's partners have chosen submission and are playing the dog's part, as they have discovered. The Allies on the other side are paying the price of resistance in the sacrifice of life for Freedom. And what of the neutrals? They are evading the choice under cover of the Allies and waxing fat meanwhile. It is not a very heroic attitude and will exclude them from any voice in the settlement. But we understand their position, and at least they are ready to fight for their own freedom. There are, however, individuals who are not ready to fight at all. They call themselves conscientious objectors, prate of the law of Christ, and pose as idealists. If they followed Christ they would sacrifice their lives for others, but they are only concerned for their own skins. Their place is in the shafts. The true idealist lies beneath the Cross.

ARTHUR SHADWELL. 


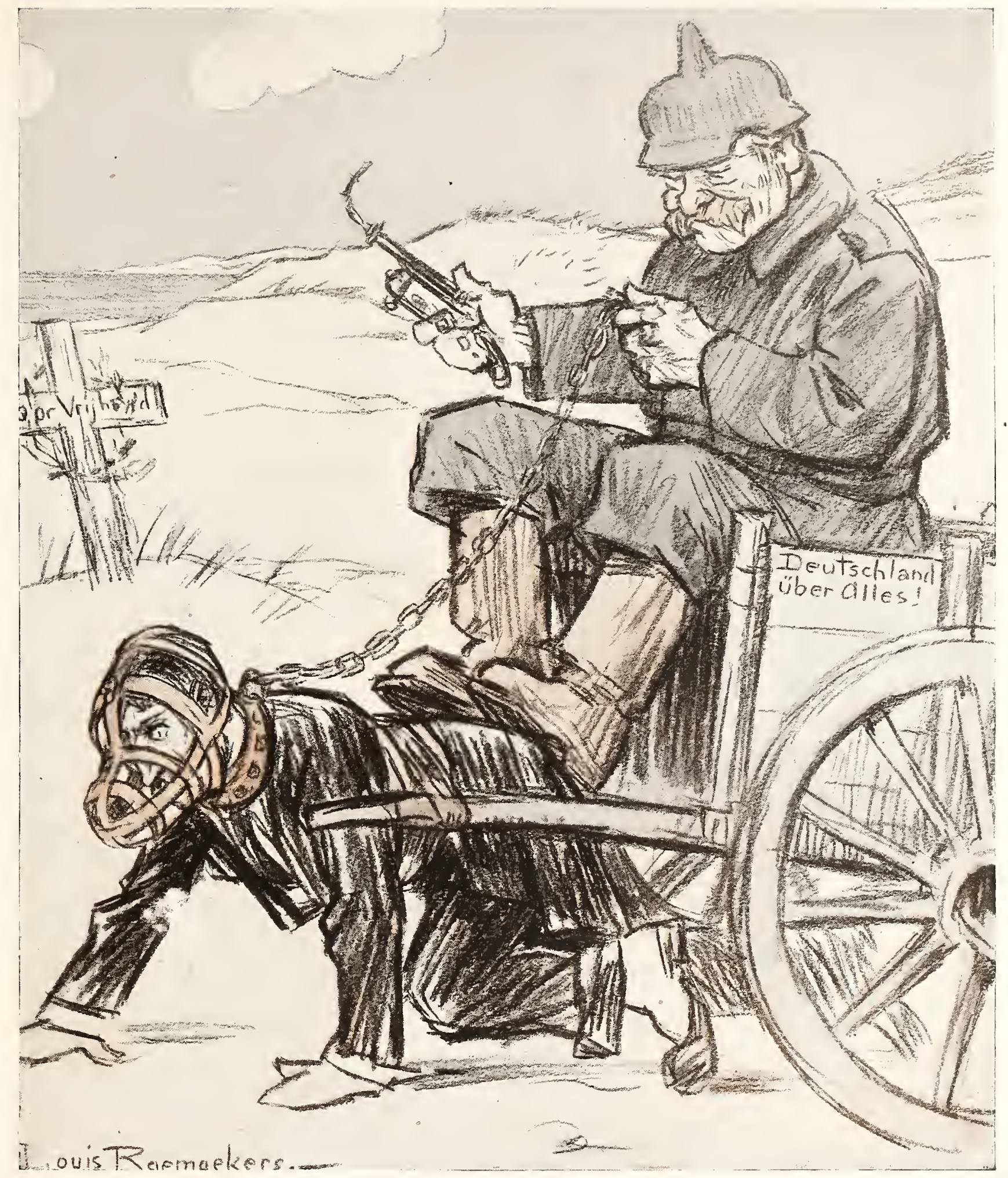

BETTER A LIVING DOG THAN A DEAD LION

The Driver: "You are a worthy Dutchman. He who lies there was a foolish jdealist." 


\section{"The Burden of the Intolerable Day"}

$\mathrm{M}$ OST people have wondered from time to time what the Kaiser thinks in his inmost heart and in the solitude of his own chamber about the condition of Germany and about the War. What impression has been made on him by the alternation of victories and failures during the last twenty months? After all he has staked everything - he has everything to lose. What does he feel? What impression do the frightful losses of his own people make on him?

Raemaekers tells in this cartoon. The Kaiser has this moment been wakened from sleep by the entrance of a big gorgeously dressed footman, carrying his morning tea. The panelling of the royal chamber in the palace at Potsdam is faintly indicated. The Kaiser sits up in bed, and a look of agony gathers on his face as he realizes that he has wakened up to the grim horror of a new day, and that the delightful time which he has just been living through was only a dream. He had dreamed that the whole thing was not true-that the War had never really occurred, and that he could face the world with a conscience clear from guilt; and now he has wakened up to bear the burden for another day. It is written in his face what he thinks. You see the deep down-drawn lines in the lower part of the face, the furrows upon the forehead, and the look almost of terror in the eyes. But a smug-faced flunkey offers him a cup of tea with buttered toast, and he must come back to the pretence of that tragi-comedy, the life of the King-Emperor.

The Dutch artist is fully alive to the comic element which underlies that tragedy. The King-Emperor, as he awakes from sleep and sits forward from that mountain of pillows, would be a purely comic figure were it not for the terrible tragedy written in his face. A footman in brilliant livery is a comic figure. The splendour of this livery brings out the comic element by its contrast to, and yet its harmony with, the stupid self-satisfaction of the countenance and the curls of the powdered hair.

The Kaiser, however, awakens to more than the pretences and shams of court life. The vast dreams which he cherished before the War of world-conquest and an invincible Germany are fled now, and he must face, open-eyed and awake, the stern reality.

WILLIAM MITCHELL RAMSAY. 


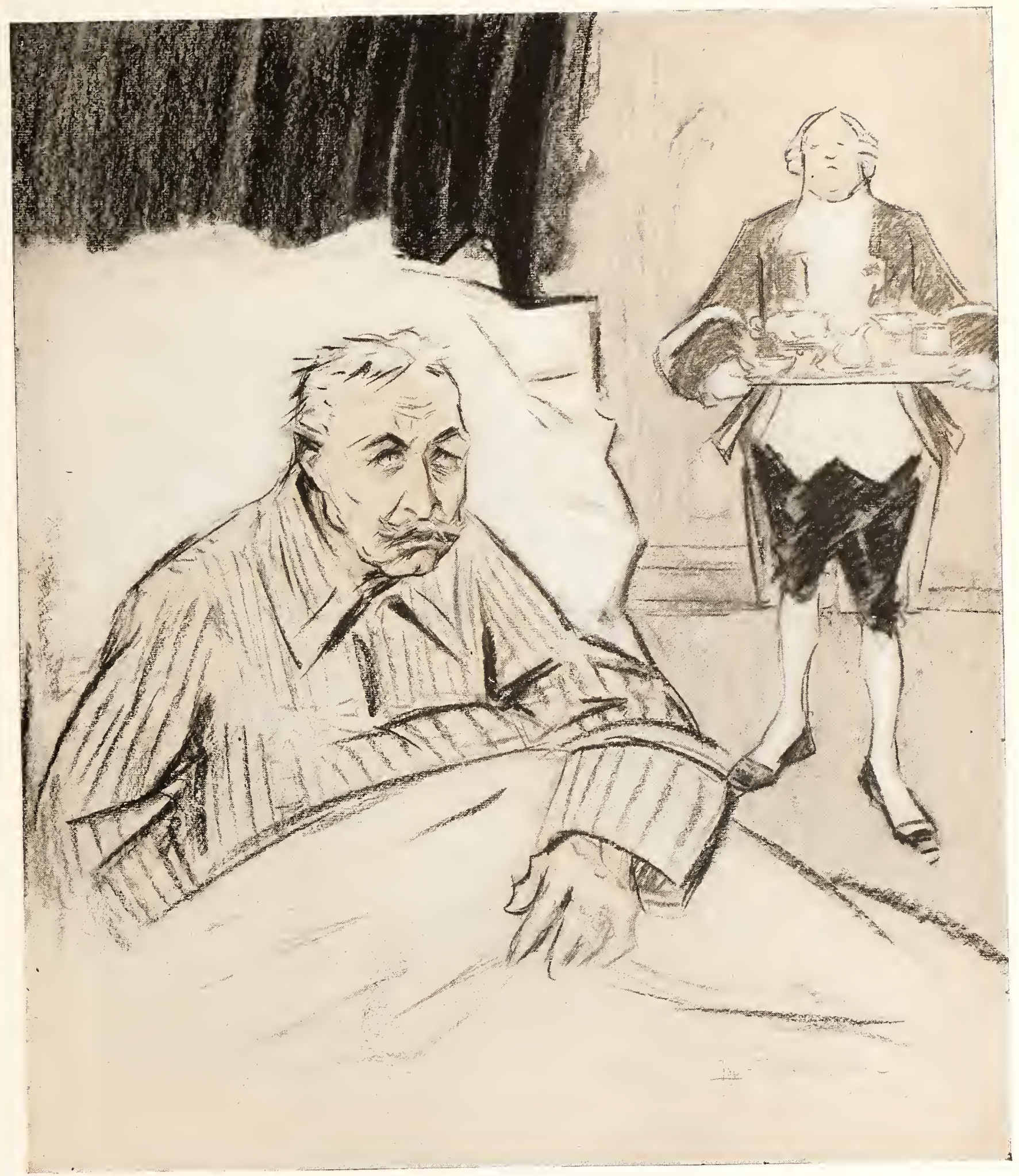

THE AWAKENING

"I had such a delightful dream that the whole thing was not true." 


\section{Eagle in Hen-run}

T HE Dutchman who could see this cartoon and not admit its simple truth would have to be a very blind pro-German. At present time it pays Germany to pretend a friendship for Holland, but the premeditated murder of Belgium is a plain object-lesson of the sort of friendship and agreement that Germany makes with a country and people which stand in her way and are too small to withstand her brute force. Can any Dutchman doubt what would be Holland's fate if Germany emerged even moderately victorious from this war? The German War Staff would give a good deal to have the control of Holland and a free passage to the sea from Antwerp. They refrain from using force to gain that control only because they cannot afford to have a fresh frontier to guard and because it is quite useful to have Holland neutral and a forbidden ground and water to the Armies and Navies of the Allies, a shield over the heart of Berlin and Germany. It would pay the Germans to have Holland with them and openly against the Allies, and they would no doubt gladly make an "agreement" to that effect; but there is little likelihood of that as long as the Dutch can visualize the "agreement" as clearly as the cartoonist has done here.

There are many people who for years past have suspected Germany's sinister designs on the whole of the Netherlands. The brutal ravaging of Belgium, the talk that already runs, openly or in whispers, in Germany of "annexation of conquered territories" and "extended borders," tell plainly the same tale-that any agreement between a small country and Germany means merely the swallowing-up of the small nation, the "agreement" of a meal with the swallower-up.

BOYD CABLE. 


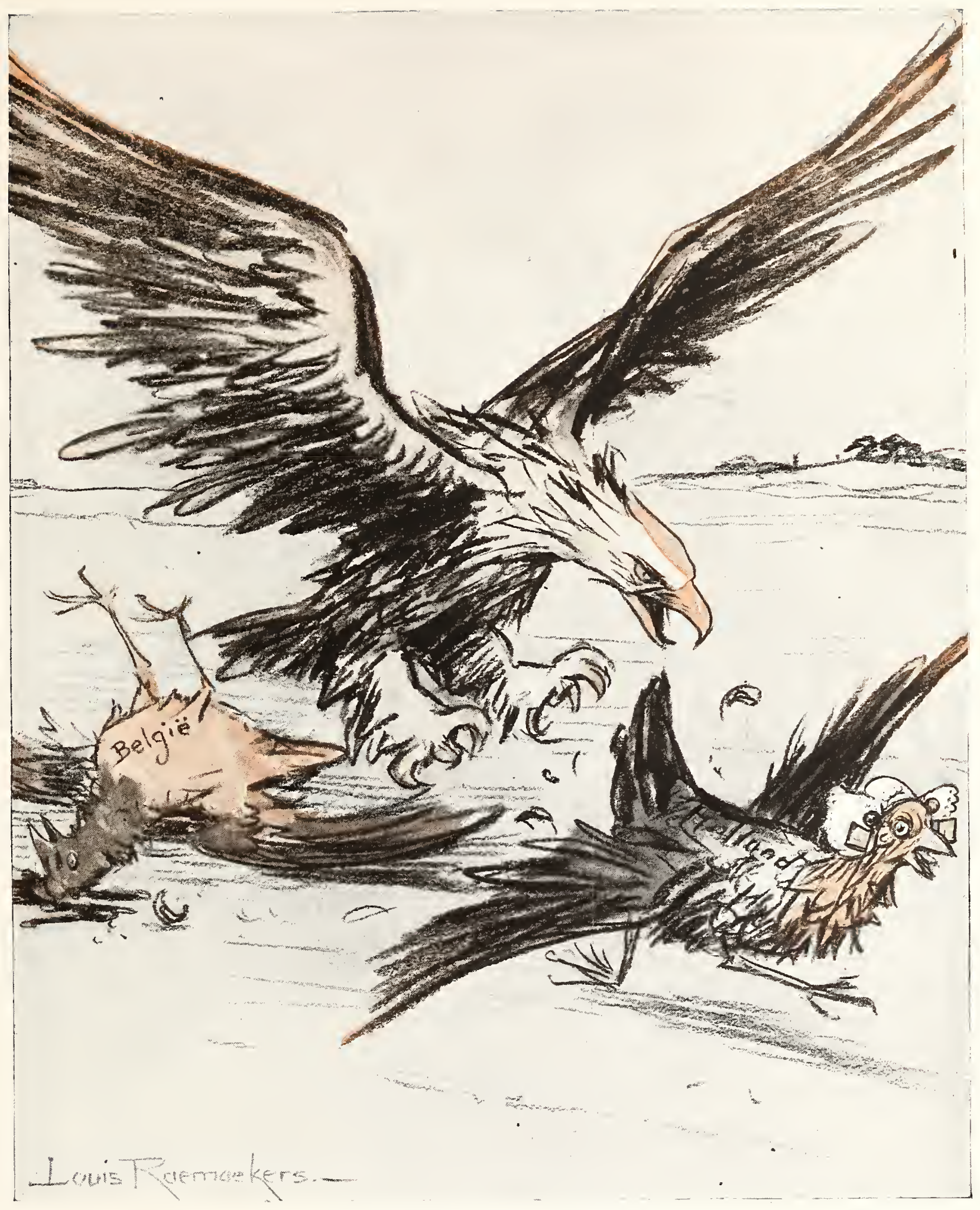

THE EAGLE IN THE HEN-RUN

German Eagle: "Come along, Dutch chicken, we will easily arrange an agreement." THE Chicken: "Yes, in your stomach." 


\section{The Future}

7 HERE can be no doubting of the future. The Allied forces, who in Raemaekers' drawing stand for Liberty, are assuredly destined to wring the neck of the Prussian eagle, which typifies the tyranny of brute force.

"For freedom's battle, once begun . . .

Though baffled oft, is ever won."

"There is only one master in this country," the Kaiser has said of Germany. "I am he, and I will not tolerate another." He has also told his people: "There is only one law-my law; the law which I myself lay down." It is supererogatory to dispute either of these imperial pronouncements. The Future contents herself with the comment: "Out of thine own mouth will I judge thee."

The Kaiser and his counsellors have now translated words into deeds, and every instrument of savagery has been since August, 1911, enlisted by Tyranny in the attempt to overthrow Liberty. "A thousand years ago," the Kaiser once declared to his Army, "the Huns under their king Attila made themselves a name which still lives in tradition." The Future replies to him that he and his fighting hordes will also live in tradition. They will be remembered for their defiance of the conscience of the world, which obeys no call but that of Liberty.

SIDNEY LEE. 


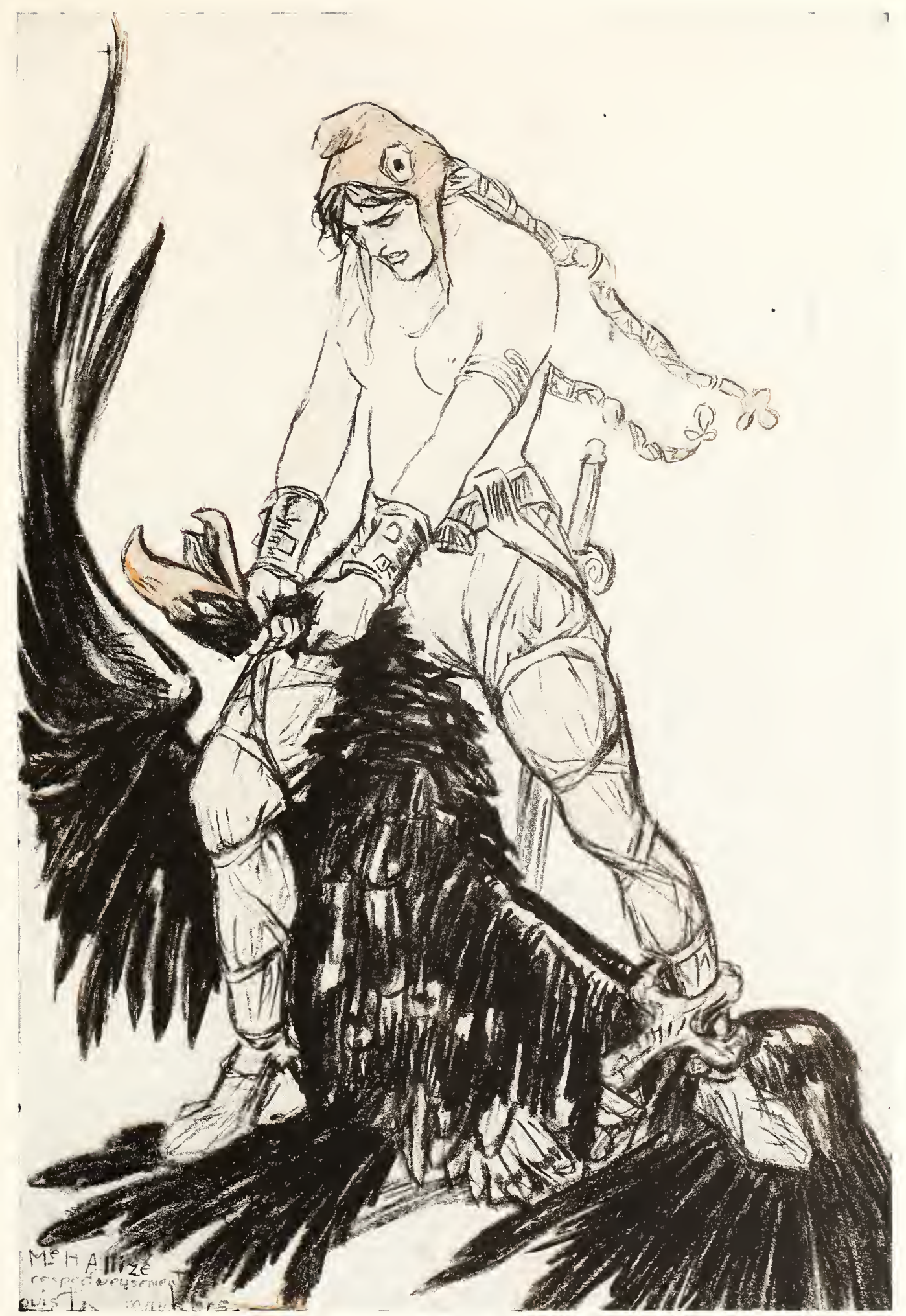

L'AVENIR 


\section{Christ or Odin?}

Y $\mathrm{OU}$ cannot well conceive a science, whether it be mathematics, or architecture, or philosophy, without its axioms, dogmas, or first principles. Without them there is no basis on which to raise the superstructure. So it is with the science of religion. Take Christianity: if it is to be taught scientifically, it must start with the most tremendous dogma, the Divinity of Christ. Either Christ was or He was not what He claimed to be. If He was not, you must shout with the Sanhedrim: "Crucify Him!" If He was, you must sing with the Church: "Come, adore Him." One thing is certain, you cannot be indifferent to His claim or to Him; you must either hate Him and His creed, like the Prussian warring Superman, or love Him and it, like England's Crusading Kings.

The cartoon before us is the finished picture which I can trace from its first rough sketch in the hands of Kant, through its different stages of development in the schools of Hegel, of Schopenhauer, of Strauss, till it was ready for its final touches in the hands of Nietzsche. In fancy I see it hung, on the line, in the Prussian picturegallery under the direction of War Lords, whose boasted aim it is that the world shall be governed only by Prussian Kultur and Prussian Religion.

The fatal mistake made by the Teutonic race in the past was, we are told, the adoption of Roman culture and Roman religion. Germany once submitted to an alien God and to an alien creed. She, the mistress of the earth, the mightiest of the mighty, and the most Kultured of the Kultured, had actually once worshipped "an uncultured peasant Galilean," and made profession of "His slave morality."

Now they had altogether done with Christ, the Nazarene. The shout had gone forth: "We will not have this Man to rule over us." In the future no gods but Thor and Odin shall rule the "world-dominating race." Prussia seemed to think the world's need to-day was the religion not of Virtue, but of Valour. "In a day now long fled was heard the cry: 'Blessed are the meek, for they shall inherit the earth,' but to-day there shall go forth the word: 'Blessed are the valiant, for they shall make the earth their throne.' In the past ye heard it said: 'Blessed are the poor in spirit,' but now I say to you: 'Blessed are the great in soul, for they shall enter into Valhalla.' Again, in the dark ages it was said to you: 'Blessed are the peacemakers,' but now in the blaze of day I say unto you: 'Blessed are the war-makers, for they shall be called, if not the children of Jahve, the children of Odin, who is greater than Jahve.'" For those who want more of this mad jargon on the same lines let me refer them to the late Professor Cramb's book on Germany and England.

With this cartoon before me, I am driven to fear that when the war is done there will rise up in Germany a louder and stronger cry against the Christianity of Christ than ever was attempled after the Franco-Prussian War. The "man of blood and iron," the man with the mailed fist and the iron heel, I much apprehend, will not be satisfied with tearing down the emblem of the physical Body of Christ, but to slake his bloodthirsty spirit he will want to go on to belabour His Mystical Body no less. God avert it!

BERNARD VAUGHAN. 


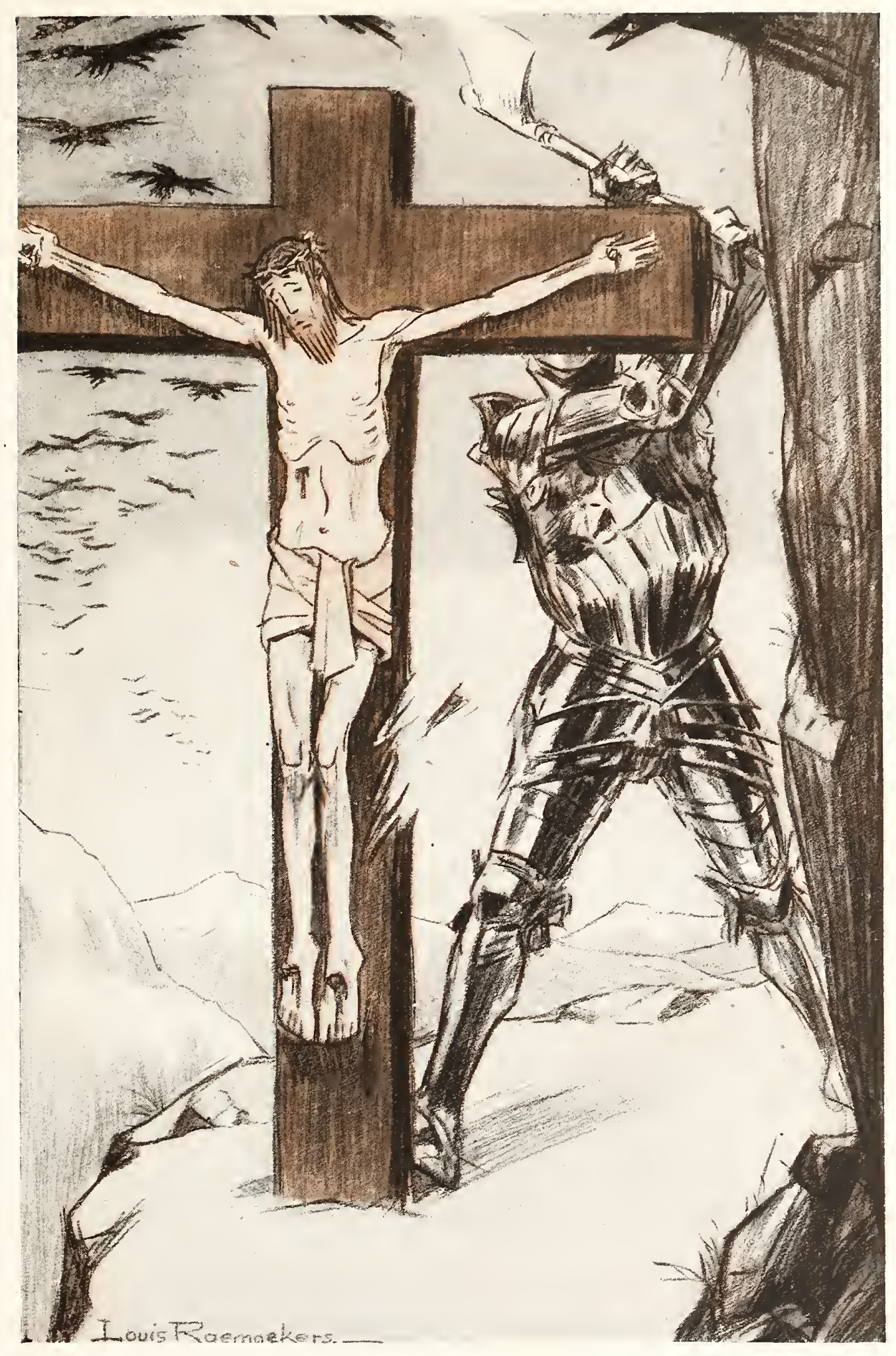

"I crush whatever resists me." 


\section{Ferdinand}

N THIS war, where the ranks of the enemy present to us so many formidable, sinister, and shocking figures, there is one, and perhaps but one, which is purely ridiculous. If we had the heart to relieve our strained feelings by laughter, it would be at the gross Coburg traitor, with his bodyguard of assassins and his hidden coat-of-mail, his shaking hands and his painted face. The world has never seen a meaner scoundrel, and we may almost bring ourselves to pity the Kaiser, whom circumstances have forced to accept on equal terms a potentate so verminous.

But we no longer smile, we are tempted rather to weep, when we think of the nation over whom this Ferdinand exercises his disastrous authority. Forty years will have expired this spring since the Christian peasants of Bulgaria rose in arms against the Turkish oppressor. After a year of wild mountain fighting, Russia, with fraternal devotion, came to their help, and at San Stefano in March, 1877, the aspirations of Bulgaria were satisfied under Russia auspices. Ten years later Ferdinand the usurper descended upon Sofia, shielded by the protection of Austria, and since then, under his poisonous rule, the honour and spirit of the once passionate and romantic Bulgarian nation have faded like a plant in poison-fumes.

Raemaekers presents the odious Ferdinand to us in the act of starting for the wars--he who faints at the sight of a drawn sword. His hired assassins guard him from his own people and from the revenge of the thousands whom he has injured. But will they always be able to secure so vile a life against the vengeance of history? How soon will Fate condescend to crush this painted creature?

EDMUND GOSSE. 


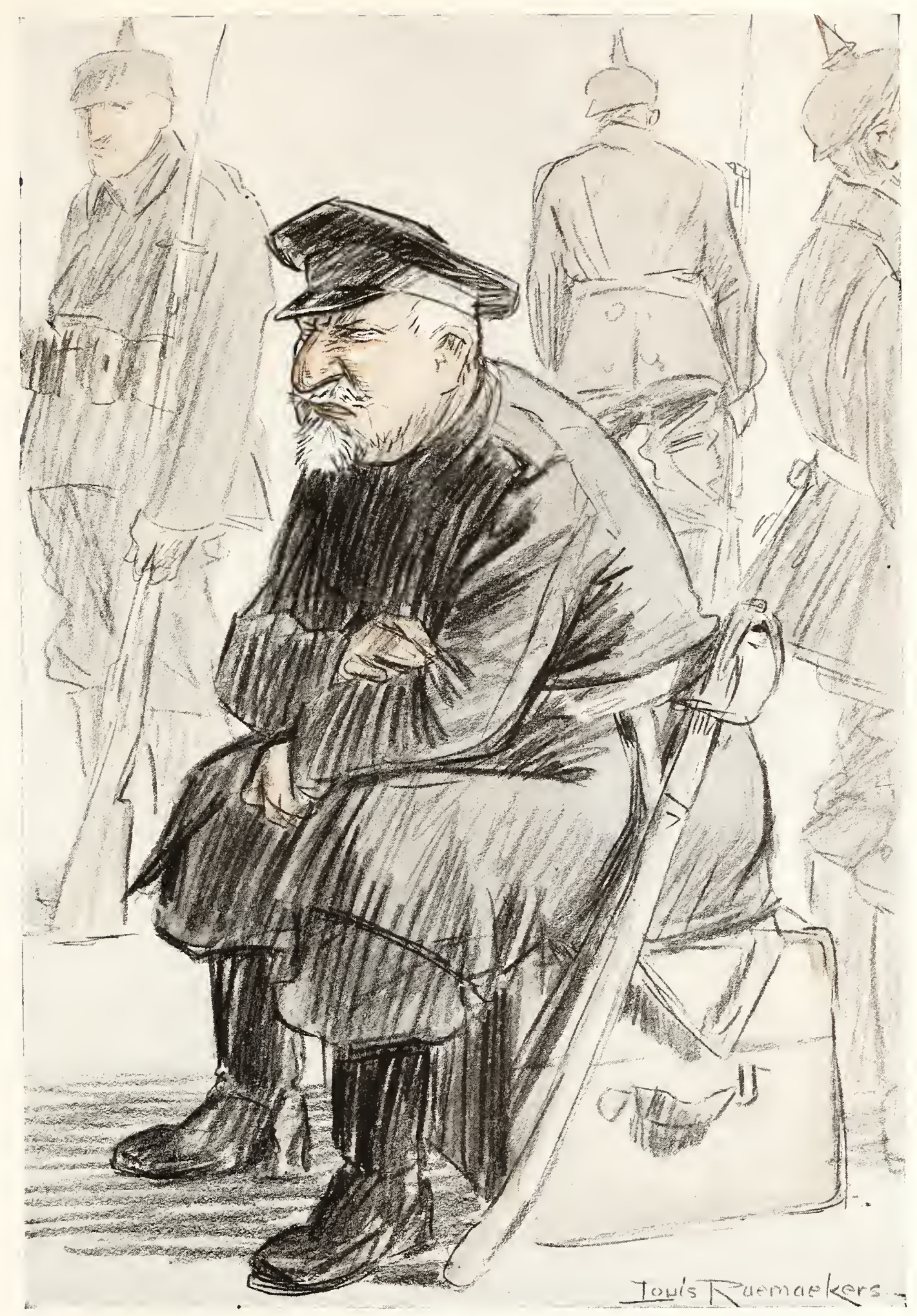

Ferdinand s'en va t'en guerre ne sait s'il reviendra. (Old Frencb song adapted.) 


\section{Juggernaut}

Y

ES, Kultur, the German Juggernaut, has passed this way. There is no mistaking the foul track of his chariot-wheels.

Kultur is the German God. But there is a greater God still.

He sees it all. He speaks,-

"Was it for this I died?-

-Black clouds of smoke that veil the sight of heaven;

Black piles of stones which yesterday were homes;

And raw black heaps which once were villages;

Fair towns in ashes, spoiled to suage thy spleen;

My temples desecrate, My priests out-cast:--

Black ruin everywhere, and red,- - a land

All swamped with blood, and savaged raw and bare;

All sickened with the reek and stench of war,

And flung a prey to pestilence and want;

- Thy work!

"For this?-

-Life's fair white flower of manhood in the dust;

Ten thousand thousand hearts made desolate;

My troubled world a seething pit of hate;

My helpless ones the victims of thy lust;-

The broken maids lift hopeless eyes to Me,

The little ones lift handless arms to Me,

The tortured women lift white lips to Me,

The eyes of murdered white-haired sires and dames

Stare up at Me. And the sad anguished eyes

Of My dumb beasts in agony.

-Thy work!"

JOHN OXENHAM. 


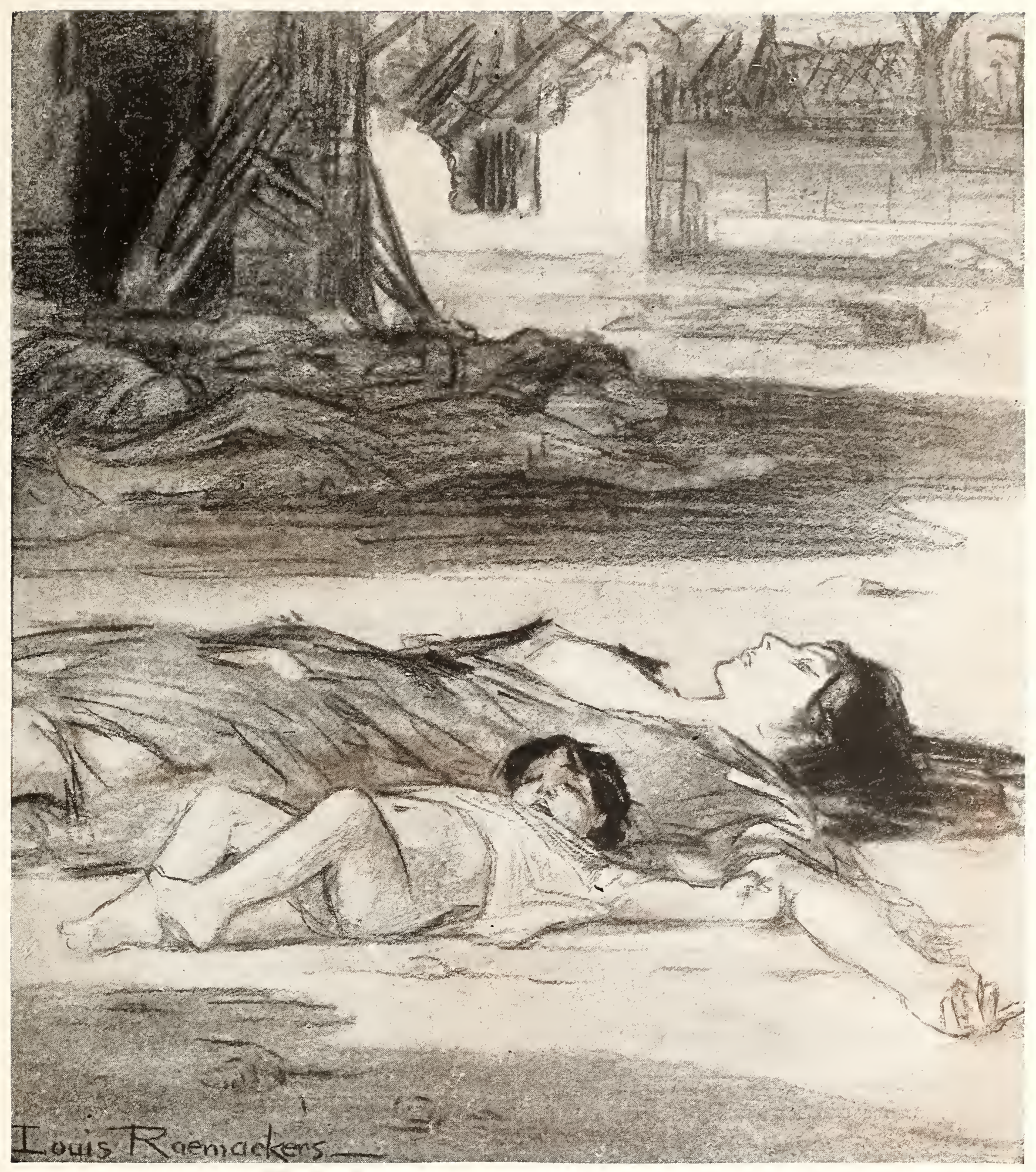

KULTUR HAS PASSED HERE 


\section{Michael and the Marks}

THE Loan: good for 100 marks!" Look at him! He is the favoured of the Earth, lives in Germany, where Kultur is peerless, and education complete (even tho' the man may become a martyr of method). War comes! and he is seen, as an almond tree in blossom his years tell, when lo! a War Loan is raised with real Helfferichian candour, and Michael has just stepped out of the Darlehnskasse, at Oberwesel-on-the-Rhine, or other seat of Kultur and War Loan finance. Are visions about? said an American humorist now gone to the Shades; and Michael, Loan note in hand, eyes reversed, after a visit to two or three offices, wants to know, and wonders whether this note can be regarded as "hab und gut," and if so, good for how much? Is it a wonder that an artist in a Neutral Country should depict German affairs as in this condition, and business done in this manner? Michael is puzzled; and in the language of the Old Kent Road, " 'e dunno where 'e are!" He is puzzled, and not without cause.

All who have followed Germany's financing of the War share Michael's perplexity. Brag is a good dog: but it does not do as a foundation for credit. Gold at Spandau was trumpeted for years as a "war chest"; but when the "best laid schemes o" mice and men gang aft agley," especially when a war does not end, as it should, after a jolly march to Paris in six weeks, through a violated and plundered Belgium, then comes the rub-and the paper which puzzles Michael. A German, possibly Dr. Helfferich, the German Finance Minister, may believe, and some do believe, that it does not matter how much "paper," in currency notes, a State, or even a Bank, may issue. The more experienced commercial and banking concerns of the world insist upon a visible material, as well as the personal security, to which the German is prone. The round-about method of issuing German War Loans unquestionably puzzles Michael; but will not impose on the world outside.

Let it be marked also, that German credit methods have been, in part, the proximate cause of this War; a system of credit-trading may last for some years only to threaten disaster and general ruin. Now, it is "neck or nothing"; Michael goes the round of the Loan offices, and behold him! Germany herself fears a crash in credit, and even the German Michael feels that it is impending. Already the mark exchanges over 30 below par.

W. M. J. WILLIAMS. 


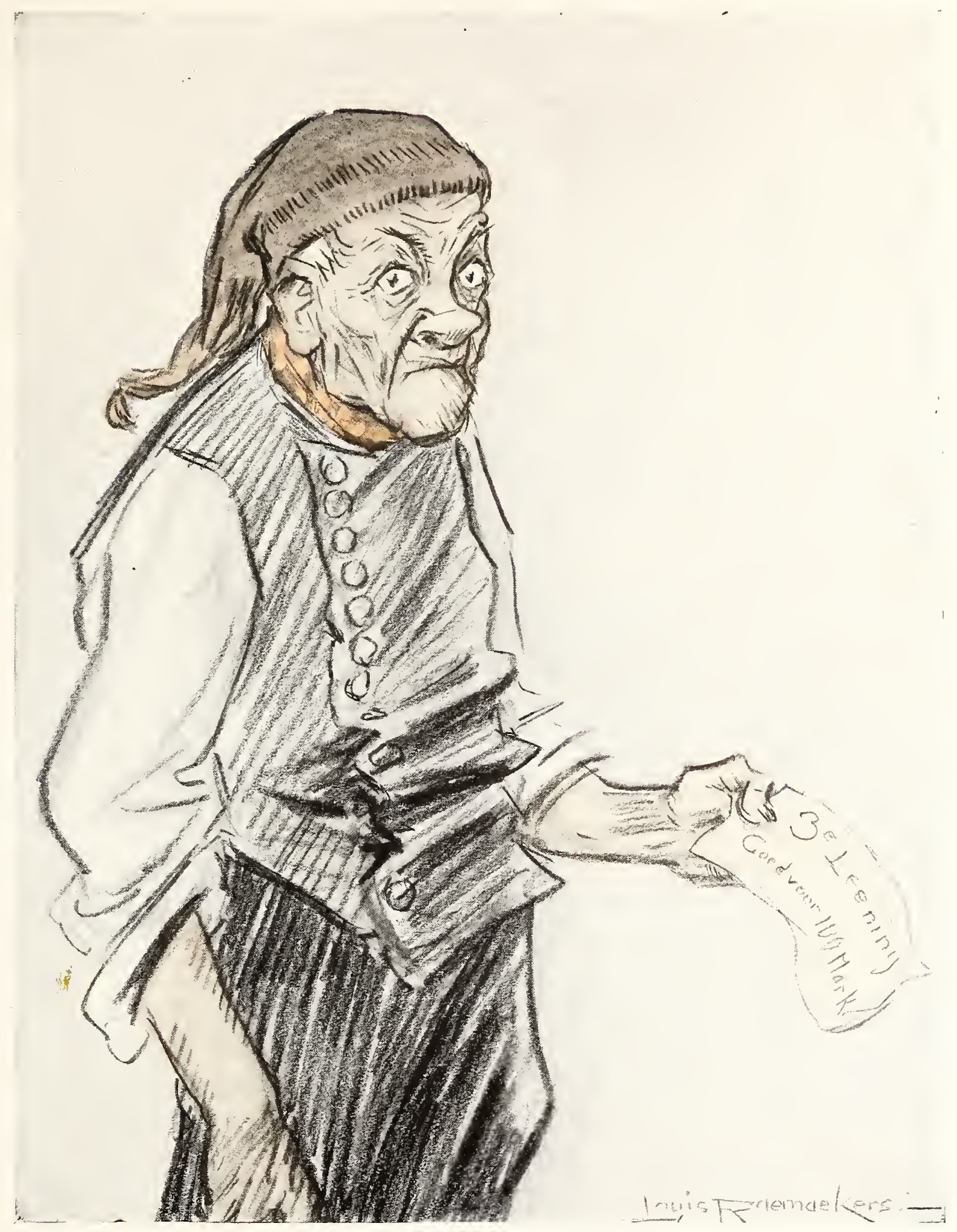

LOAN JUGGLERY

Michael: "For my Ioo marks I obtained a receipt. I gave this for a second Ioo marks and I received a second receipt. For the third loan I gave the second receipt. Have I invested 300 marks and has the Government got 300, or have both of us got nothing?" 


\title{
Their Beresina
}

\author{
$I$ \\ S IT still a long way to the Beresina?" \\ The whole civilized world sincerely hopes not.
}

Death, with the grin on his fleshless face, is hurrying them along to it as fast as his troika can go. Three black horses abreast he drivesDishonour, Disappointment, and Disgrace-and the more audacious of the carrion-crows fly croaking ominously alongside.

Little Willie, with the insignia of his family's doom on his head, is not happy in his mind. "Father's" plans have not worked smoothly, his promises have not been fulfilled. Little Willie is concerned for his own future. He is the only soul in the world who is.

When the First-the real-Napoleon entered Russia, on June 24, 1812, he led an army of 414,000 men-the grande armée. When the great retreat began from burnt-out Moscow he had less than 100,000. By the time the Beresina was reached but little of the grand army was left. "Of the cavalry reserve, formerly 32,000 men, only 100 answered the muster-roll." The passage of the river, which was to interpose its barrier between him and the pursuing Russians, was an inferno of panic, selfishness, and utter demoralization. Finally, to secure his own safety, Napoleon had the bridges burnt before half his men had crossed. The roll-call that night totalled 8,000 gaunt spectres, hardly to be called men.

"Father, is it still a long way to the Beresina?"

We may surely and rightly put up that question as a prayer to the God whom Kaiser William claims as friend, but whom he has flouted and bruised as never mortal man since time began has bruised and flouted friend before.

"Is it still a long way to the Beresina?"

God grant them a short quick course, an end forever to militarism, to the wastage it has entailed, and to all those evils which have made such things possible in this year of grace 1916 .

JOHN OXENHAM. 


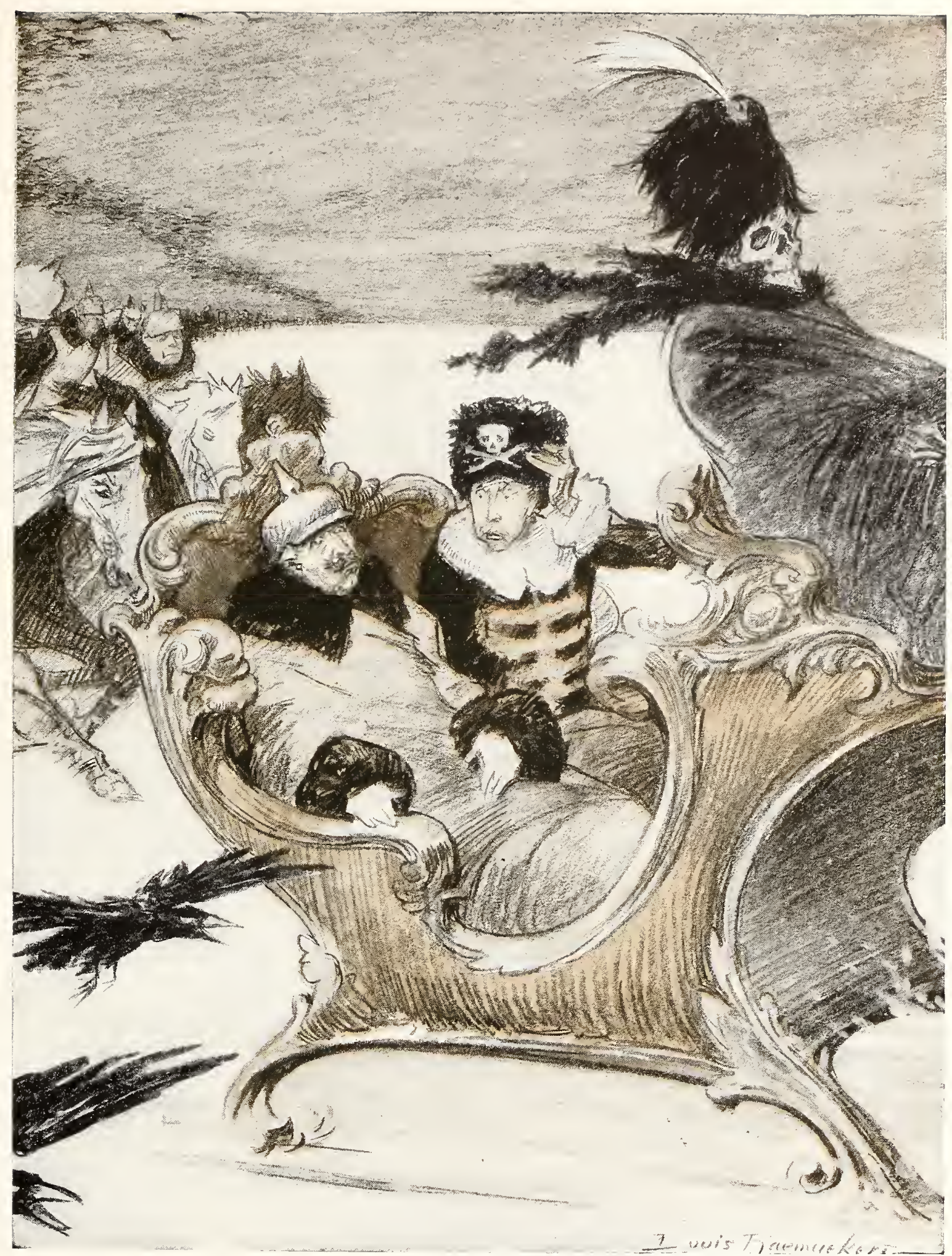

"Father, is it still a long way to the Beresina?" 


\section{New Peace Offers}

$\mathrm{T}$ HE present policy of Germany is a curious mixture of underhand diplomacy and boastful threats. If she desires to impress the neutral States, she vaunts the great conquests that she has been able to accomplish. She points out, especially to Roumania and to Greece, how terrible is her vengeance on States which defy her, such as Belgium and Serbia, while vague promises are given to her NearEastern Allies-Bulgaria and Turkey-that they will have large additions to their territory as a reward for compliance with the dictates of Berlin.

But, on the other hand, it is very clear that, as part and parcel of this vigorous offensive, Germany is already in more quarters than one suggesting that she is quite open to offers of peace. As every one knows, Von Bülow in Switzerland is the head and controlling agent of a great movement in the direction of peace; while lately we have heard of offers made to Belgium that if she will acknowledge a commercial dependence on the Central Empires her territory will be restored to her. Similar movements are going on in America, because throughout Germany still seeks to pose as a nation which was attacked and had to defend herself, and is therefore quite ready to listen if any reasonable offers come from her enemies to bring the war to a close.

The unhappy German Imperial Chancellor has to play his part in this sorry comedy with such skill as he can manage. To his German countrymen he has to proclain that the war has been one brilliant progress from the start to the present time. This must be done in order to allay the apprehensions of Berlin and to propitiate the ever-increasing demand for more plentiful supplies of food. Secretly he has to work quite as hard to secure for the Central Empires such a conclusion of hostilities as will leave them masters of Europe. And, without doubt, he has to put up with a good many indignities in the process. "The worst of it is, I must always deny having been there." Kicked out by the Allies, he has to pretend that no advances were ever made. Perhaps, however, such a task is not uncongenial to the man who began by asserting that solemnly ratified treaties were only "scraps of paper."

IV. L. COURTNEY. 


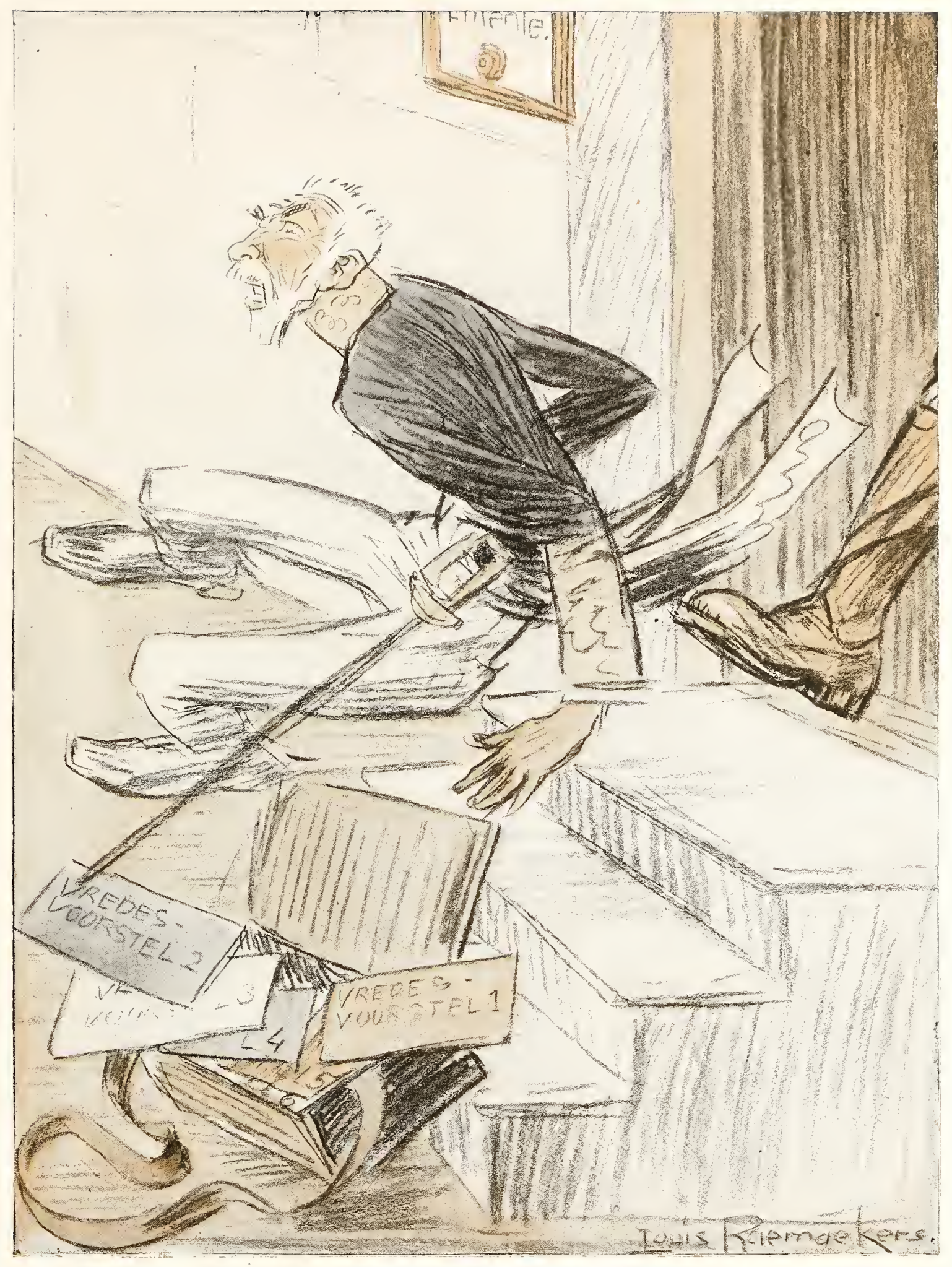

NEW PEACE OFFERS

Von Bethmann-Hollweg: "The worst of it is, I must always deny having been there." 


\section{The Shields of Rosselaere}

7 HE climax of meanness and selfishness would seem to be reached when an armed man shelters himself behind the unarmed; yet it is not the climax, for here the artist depicts a body of German troops sheltering themselves behind women, calculating that the Belgians will not fire on their own countrywomen and unarmed friends, and that so the attack may safely gain an advantage.

There is a studied contrast between the calm, orderly march of the troops with shouldered arms and the huddled, disorderly progress to which the townspeople are compelled. These are not marching: they are going to their death. Several of the women have their hands raised in frantic anguish, their eyes are like the eyes of insanity, and one at least has her mouth open to emit a shriek of terror. Two of the men are in even worse condition; they are collapsing, one forward, one backward, with outstretched hands as if grasping at help. The rest march on, courageously or stolidy. Some seem hardly to understand, some understand and accept their fate with calm resignation.

One old woman walks quietly with bowed head submissive. In the front walks a priest, his hand raised in the gesture of blessing his flock. The heroism of the Catholic priesthood both in France and in Belgium forms one of the most honourable features of the Great War, and stands in striking contrast with the calculating diplomatic policy of the Papacy. There is always the same tendency in the "chief priests" of every race and period to be tempted to sacrifice moral considerations to expediency, and to prefer the empty fabric of an imposing Church establishment to the people who make the Church. But the clergy of Belgium are there to prove what the Church can do for mankind. This cartoon would be incomplete and would deserve condemnation as inartistic if it were not redeemed by the priest and the old woman.

WILLIAM MITCHELL RAMSAY. 


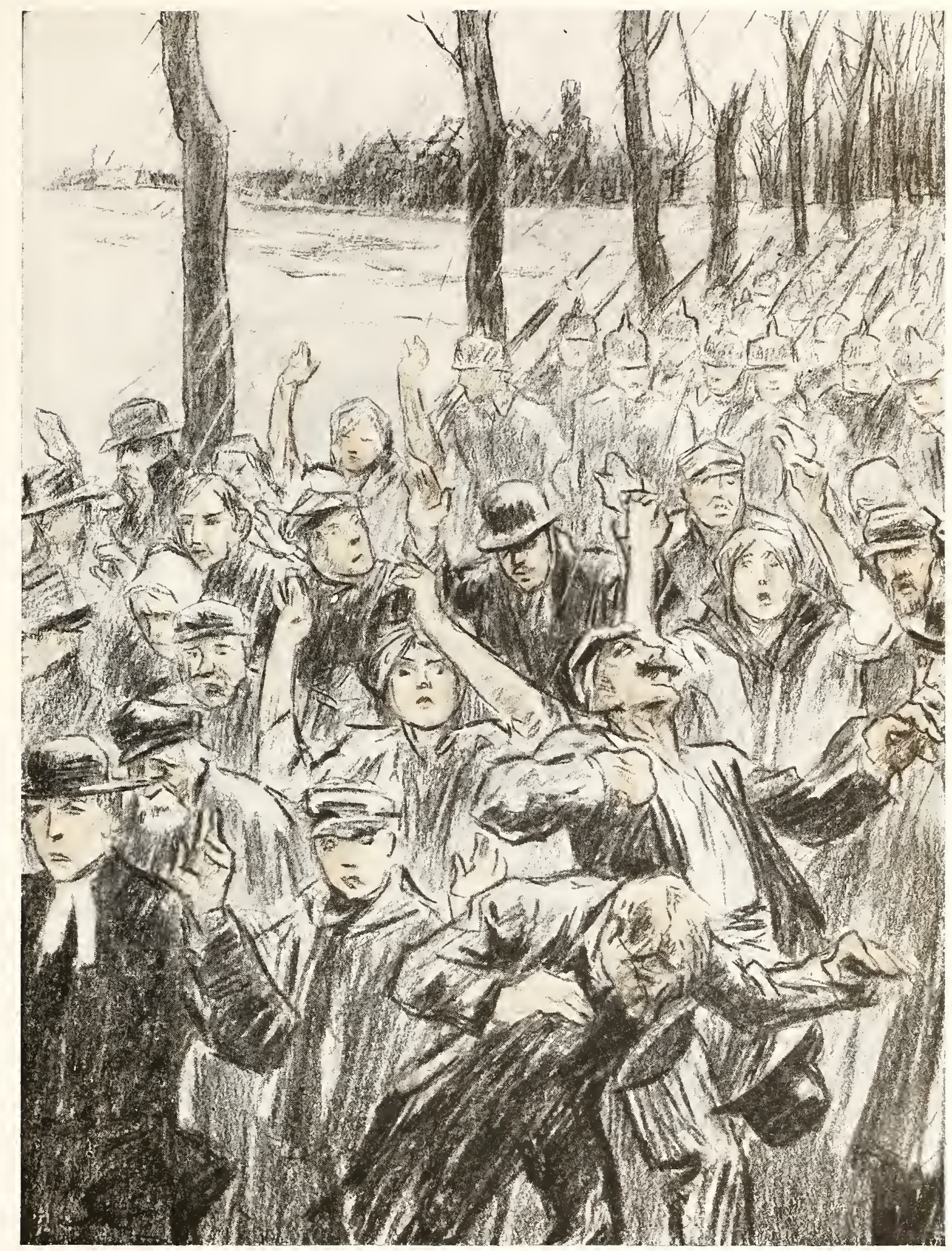

THE SHIELDS OF ROSSELAERE

At Rosselaere the German troops forced the Belgian townsfolk to march in front of them. 


\section{The Obstinacy of Nicholas}

$\mathrm{T}$

HE venerable quip that what is firmness in ourselves is obstinacy in our opponents is illustrated with a ludicrous explicitness in the whole tenor of German official utterance since the failure of the great drives. The obtuseness of the Allies is so abysmal (it is again and again complained in the Reichstag and through Wolff) that they are unable to see that Germany is the permanently triumphant victor. Whereas for Germany, whose cause even the neutrals judge to be lost, to hold out at the cost of untold blood and treasure is merely the manifestation of heaven-conferred German steadfastness. The Army into whose obstinate corporate head it is hardest to drive the idea of German military all-powerfulness is the Russian, of which retreating units, actually armed with staves against a superbly equipped (but innocent and wantonly attacked) foe, were so stupid as to forget how to be broken and demoralized.

And this long, imperturbable, verdamte Nicholas, who was declared on the highest German authority (and what higher?) to be annihilated twice, having turned a smashing tactical defeat into strategical victory, bobs up serenely in another and most inconvenient place. Absurd; particularly when "what I tell you three times is true." . . . Neonapoleon didn't remember Moscow. But he will.

JOSEPH THORP. 


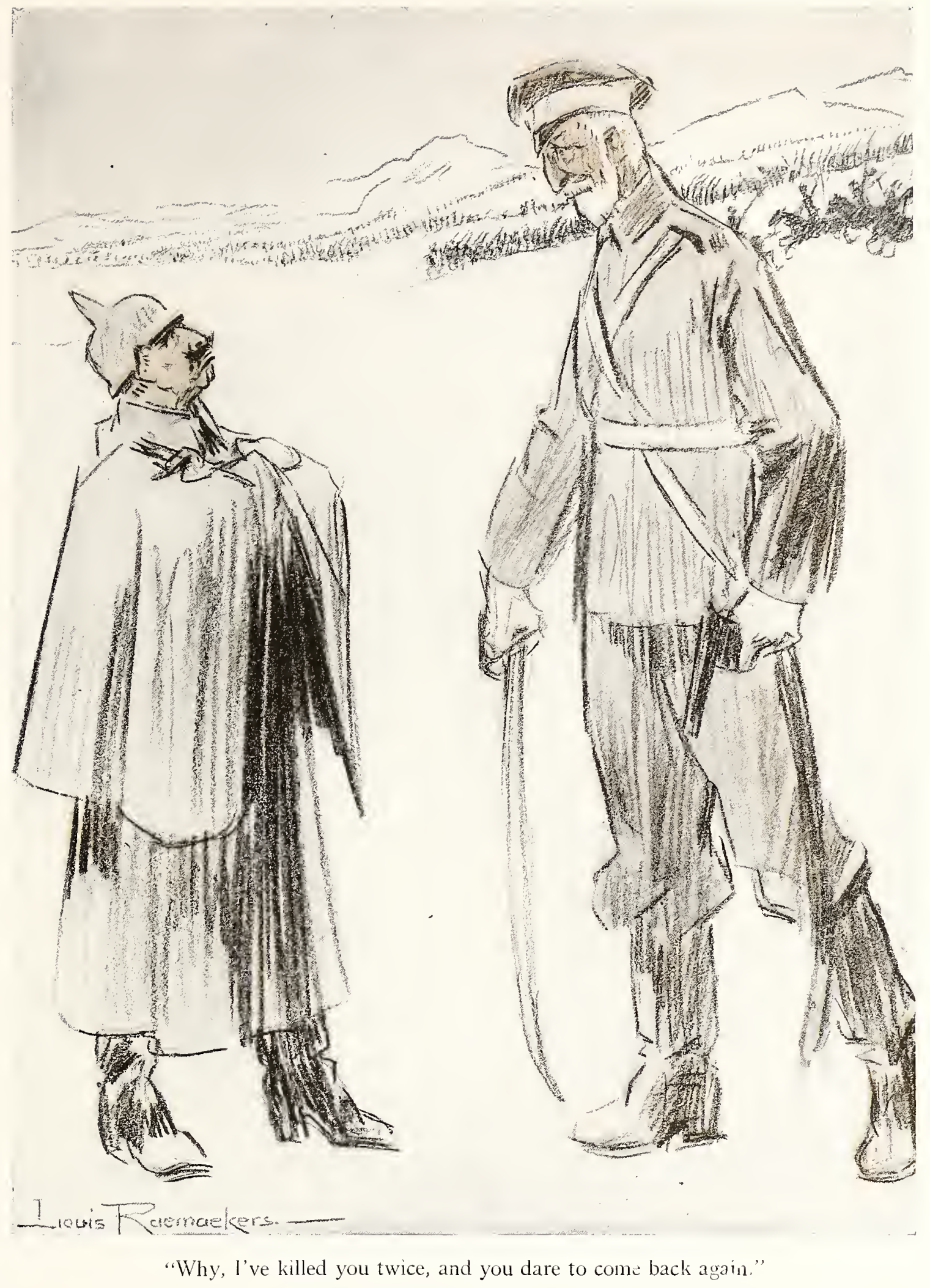




\section{The Order of Merit}

TURKEY had no illusions from the beginning on the subject of the war. If the choice had been left to the nation she would not have become Germany's catspaw. Unfortunately for Turkey, she has had no choice. For years upon years the Sultan Abdul Hamid was Turkey. Opposition to his will meant death for his opponent. Thus Turkey became inarticulate. Her voice was struck dumb. The revolution was looked upon hopefully as the dawn of a new era. Abdul Hamid was dethroned; his brother, a puppet, was exalted, anointed, and enthroned. Power passed from the Crown, not, as expected, to the people and its representatives, but into the hands of a youthful adventurer, in German pay, who has led his country from one folly to another.

Turkey did not want to fight, but she had no choice, and so she was dragged in by the heels. She has lost much besides her independence. The crafty German has drained her of supplies while giving naught in return. The German's policy is to strive throughout for a weak Turkey. The weaker Turkey can be made, the better will it be for Germany, which hopes still, no matter what may happen elsewhere, so to manipulate things as to dominate the Ottoman Empire after the war.

Turkey is still a rich country, in spite of her enormous sacrifices in the past decade. She has been exploited from end to end by the German adventurer, who will continue the process of bleeding so long as there is safety in the method; but Turkey is beginning to ask herself, as does the figure of the fat Pasha in the cartoon: "And is this all the compensation I get?" An Iron Cross does not pay for the loss of half a million good soldiers. Yet that is the exact measure of Turkey's reward.

RALPH D. BLUMENFELD. 


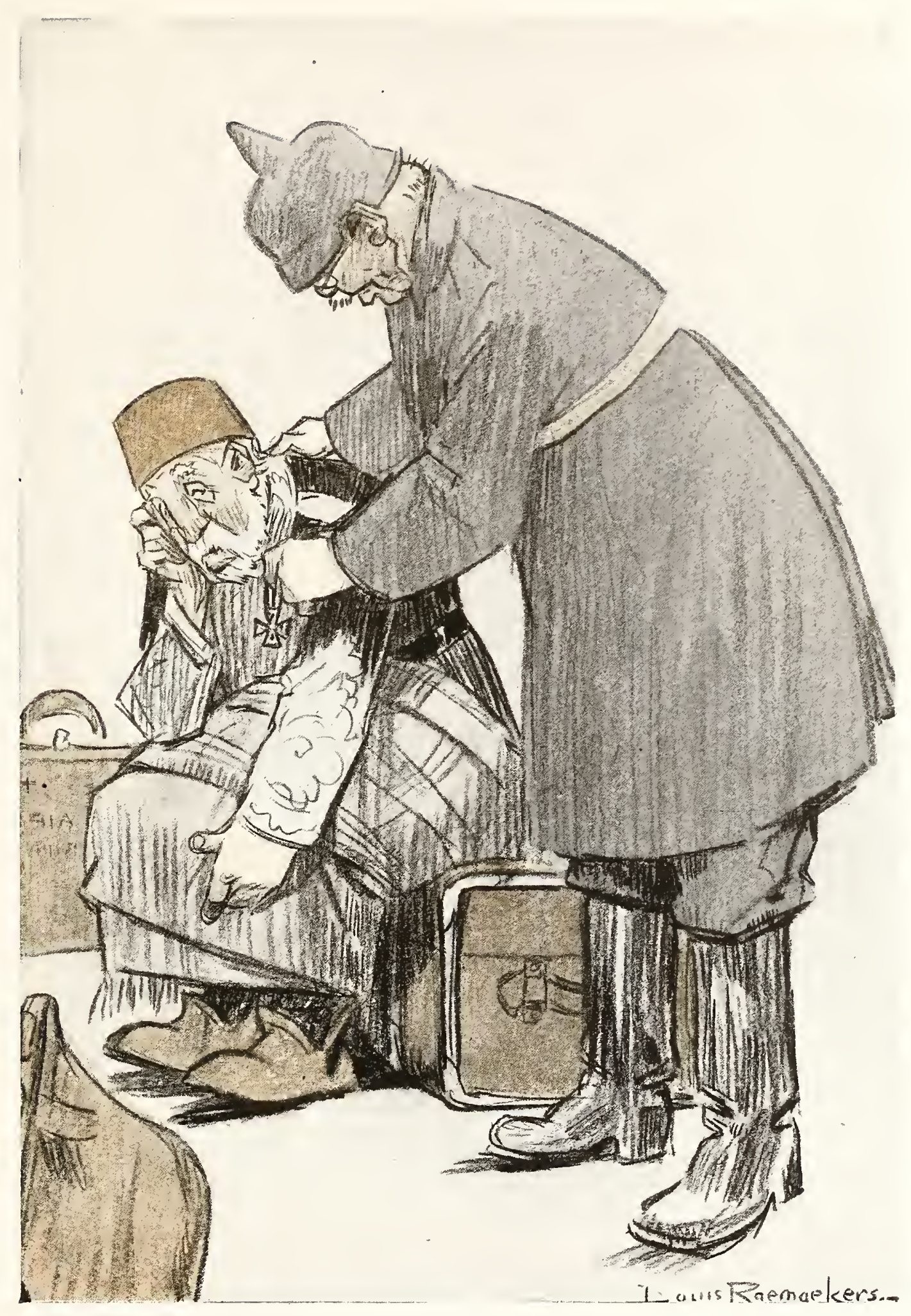

THE ORDER OF MERIT

TURKEY: "And is this all the compensation I get?" 


\section{The Marshes of Pinsk}

I WHAT are we most like our kinsmen the Germans, and in what most unlike? I was convicted of Teutonism when first, in Germany, I ate "brod und butter," and found the words pronounced in an English way, slurred. But if we are like the Germans in the names of simple and childish things, we grow more unlike them, we draw farther apart from them, as we grow up. We love war less and less, as they love it more. We love our word of honour more and more as they, for the love of war, love their word less.

There is no nation in the world more unlike us; because there is no war so perfect, so conscious, so complete as the German. And being thus all-predominant, German war is the greatest of outrages on life and death. We English have a singular degree of respect for the dead. It has no doubt expressed itself in some slight follies and vulgarities, such as certain funeral customs, not long gone by; but such respect is a national virtue and emotion. No nation loving war harbours that virtue. And in nothing do the kinsmen with whom we have much language in common differ from us more than in the policy that brought this Prussian host to cumber the stagnant waters of the Marshes of Pinsk.

The love of war has cast them there, displayed, profaned, in the "cold obstruction" of their dissolution. Corruption is not sensible corruption when it is a secret in earth where no eye, no hand, no breathing can be aware of it. There is no offence in the grave. But the lover of war, the Power that loved war so much as to break its oath for the love of war, and for the love of war to strike aside the hand of the peace-maker, Arbitration, that Power has chosen thus to expose and to betray the multitude of the dead.

ALICE MEYNELL. 


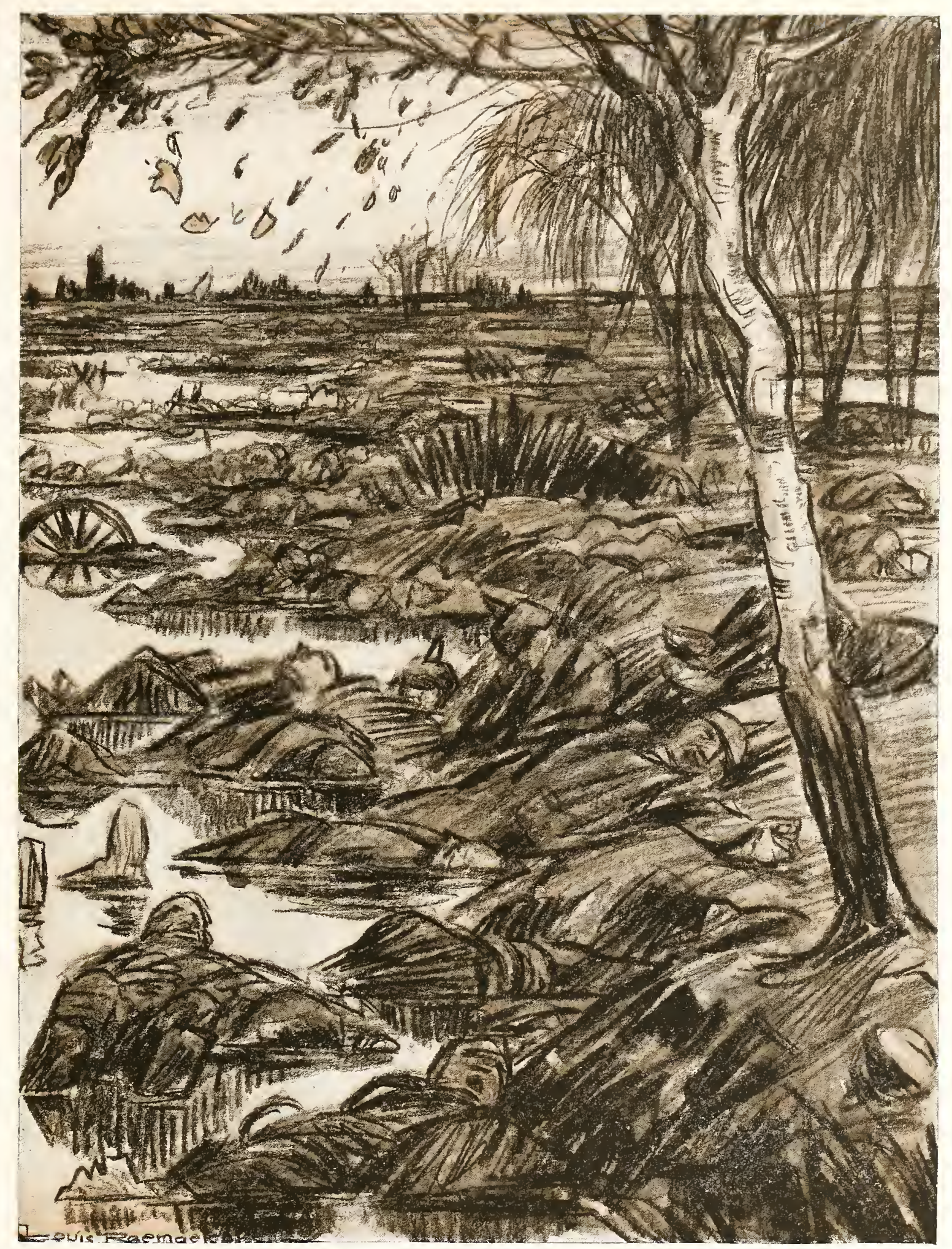

THE MARSHES OF PINSK, NOVEMBER, 1915.

The Kaiser said last spring: "When the leaves fall you'll have peace." They have! 


\section{God With Us}

7 HREE apaches sit crouched in shelter waiting the moment to strike. One is old and gaga, his ancient fingers splayed on the ground to support him and his face puckered with the petulance of age. One is a soft shapeless figure-clearly with small heart for the business, for he squats there as limp as a sack. One is the true stage conspirator with a long pendulous nose and narrow eyes. His knife is in his teeth, and he would clearly like to keep it there, for he has no stomach for a fight. He will only strike if he can get in a secret blow. The leader of the gang has the furtive air of the criminal, his chin sunk on his breast, and his cap slouched over his brows. His right hand holds a stiletto, his pockets bulge with weapons or plunder, his left hand is raised with the air of a priest encouraging his flock. And his words are the words of religion- "God with us." At the sign the motley crew will get to work.

It is wholesome to strip the wrappings from grandiose things. Public crimes are no less crimes because they are committed to the sound of trumpets, and the chicanery of crowned intriguers is morally the same as the tricks of hedge bandits. It is privilege of genius to get down to fundamentals. Behind the stately speech of international pourparlers and the rhetoric of national appeals burn the old lust and greed and rapine. A stab in the dark is still a stab in the dark though courts and councils are the miscreants. A war of aggression is not less brigandage because the armies march to proud songs and summon the Almighty to their aid.

Raemaekers has done much to clear the eyes of humanity. The monarch of Felix Austria, with the mantle of the Holy Roman Empire still dragging from his shoulders, is no more than a puzzled, broken old man, crowded in this bad business beside the Grand Turk, against whom his fathers defended Europe. The preposterous Ferdinand, shorn of his bombast, is only a chicken-hearted assassin. The leader of the band, the All Highest himself, when stripped of his white cloak and silver helmet, shows the slouch and the furtive ferocity of the streetcorner bravo. And the cry "God with us," which once rallied Crusades, has become on such lips the signal of the apache.

JOHN BUCHAN. 


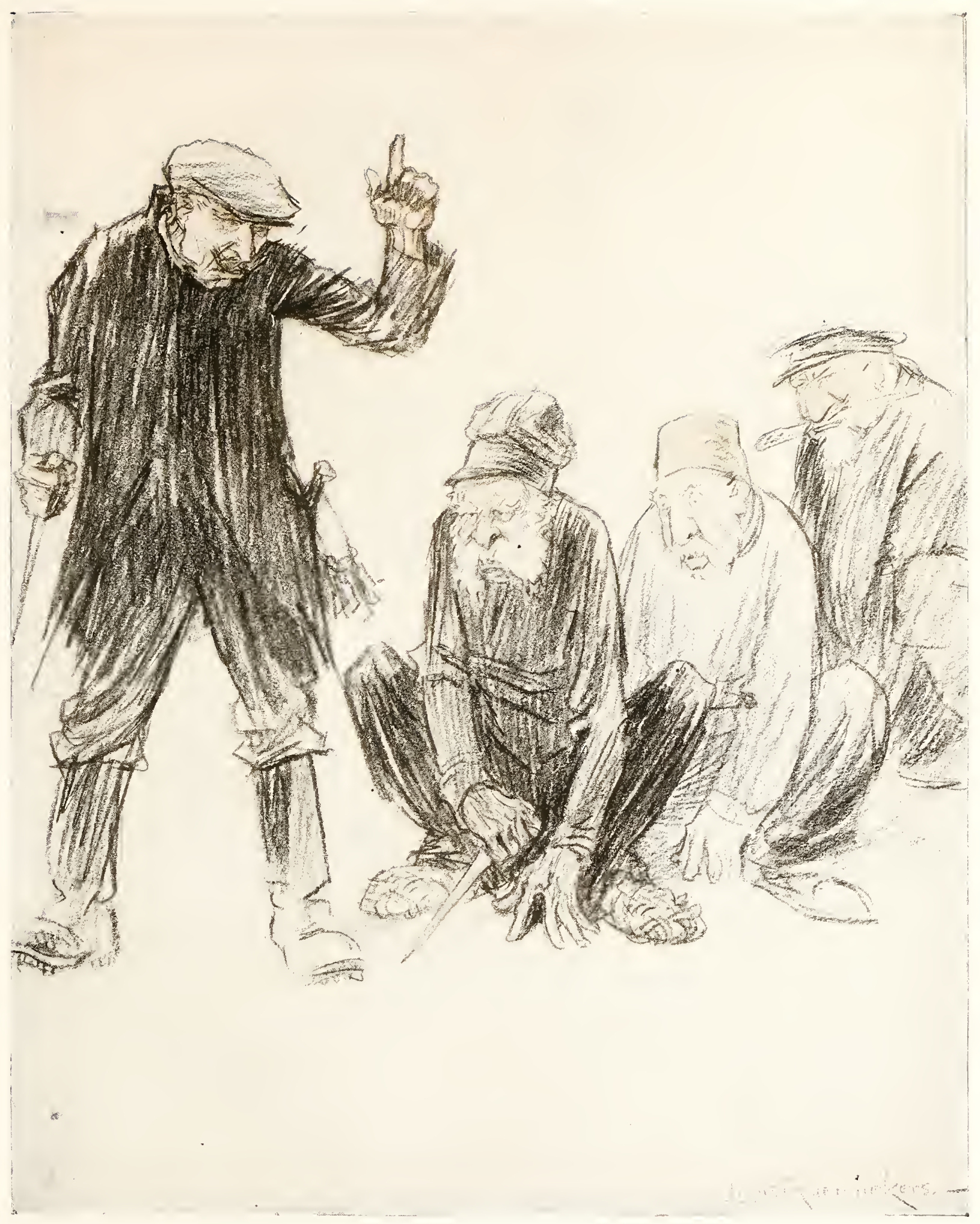

GOD WITH US

"At the command 'Gott mit uns' you will go for them." 


\section{Ferdinand the Chameleon}

$\mathrm{T}$

HERE is one whole field of the evil international influence of Germany in which Ferdinand of Bulgaria is a much more important and symbolic person than William of Prussia. He is, of course, a cynical cosmopolitan. He is in great part a Jew, and an advanced type of that mauvais juif who is the principal obstacle to all the attempts of the more genuine and honest Jews to erect a rational status for their people.

Like almost every man of this type, he is a Jingo without being a patriot. That is to say, he is of the type that believes in big armaments and in a diplomacy even more brutal than armaments; but the militarism and diplomacy are not humanized either by the ancient national sanctities which surround the Czar of Russia, or the spontaneous national popularity which established the King of Serbia. He is not national, but international; and even in his peaceful activities has been not so much a neutral as a spy.

In the accompanying cartoon the Dutch caricaturist has thrust with his pencil at the central point of this falsity. It is something which is probably the central point of everything everywhere, but is especially the central point of everything connected with the deep quarrels of Eastern Europe. It is religion. Russian Orthodoxy is an enormously genuine thing; Austrian Romanism is a genuine thing; Islam is a genuine thing; Israel, for that matter, is also a genuine thing.

But Ferdinand of Bulgaria is not a genuine thing; and he represents the whole part played by Prussia in these ancient disputes. That part is the very reverse of genuine; it is a piece of ludicrous and transparent humbug. If Prussia had any religion, it would be a northern perversion of Protestantism utterly distant from and indifferent to the controversies of Slavonic Catholics. But Prussia has no religion. For her there is no God; and Ferdinand is his prophet.

\section{G. K. CHESTERTON.}




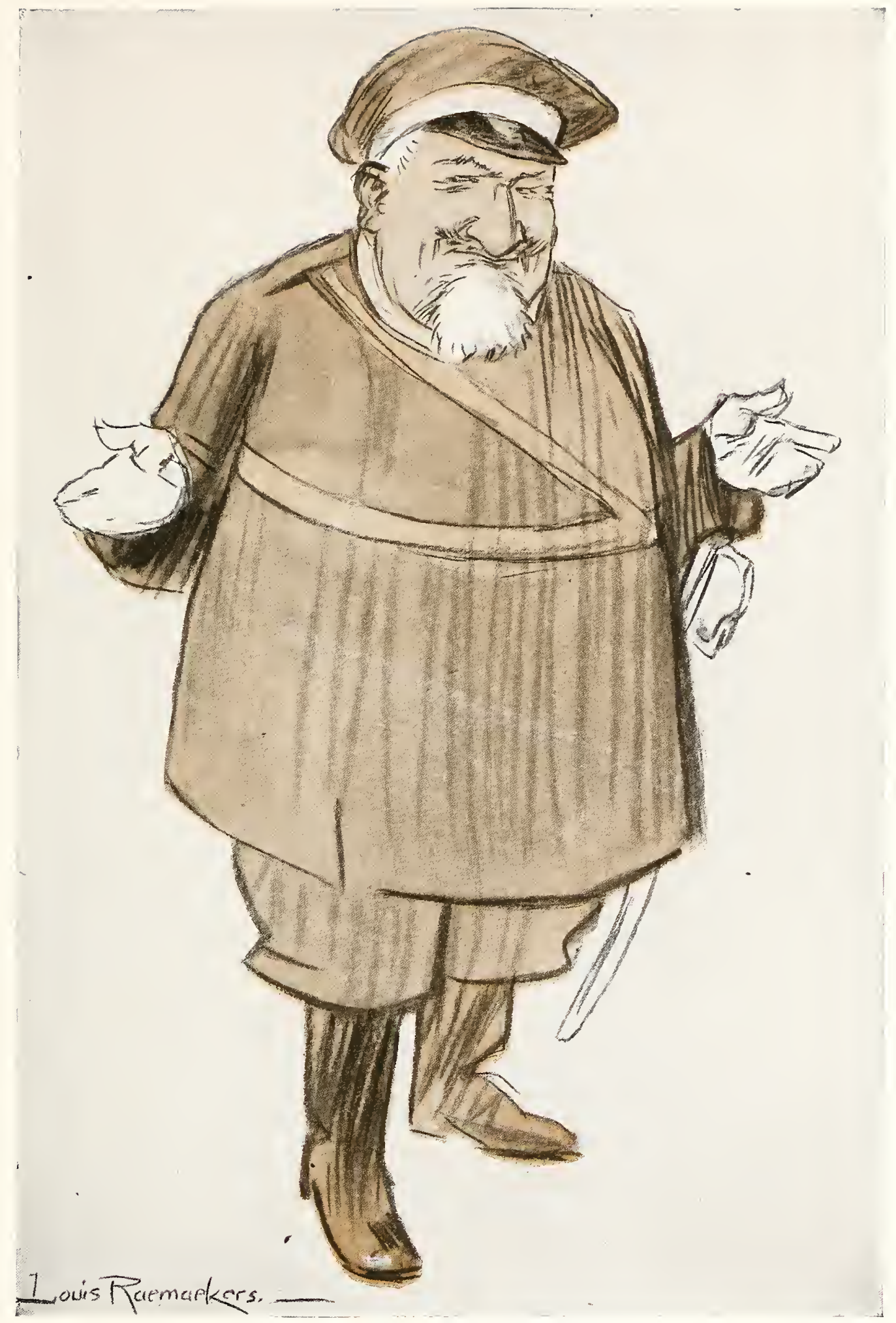

FERDINAND THE CHAMELEON

"I was a Catholic, but, needing Russian help, I became a Greeh Orthodo:. Now I need the Austrians, I again become Catholic. Should things turn out badly, I can again revert to Greek Orthodoxy." 


\section{The Latin Sisters}

T HE Latin Sisters! Note carefully the expression of France as contrasted with that of Italy. France, violated by the Hun, exhibits grim determination made sacrosanct by suffering. Italy's face glows with enthusiasm. One can conceive of the one fighting on to avenge her martyrs, steadfast to the inevitable end when Right triumphs over Might. One can conceive of the other drawing her sword because of the blood tie which links them together in a bond that craft and specious lies have tried in vain to sunder. What do they stand for, these two noble sisters? Everything which can be included in the word-ART. Everything which has built up, stone upon stone, the stately temple of Civilization, everything which has served to humanize mankind and to differentiate him from the beasts of Prussia.

Looking at these two sisters, one wonders that there are still to be found in England mothers who allow their children to be taught German. One hazards the conjecture that it might well be imparted to exceptionally wicked children, if there be any, because none can question that the Teutonic tongue will be spoken almost exclusively in the nethermost deeps of Hades until, and probably after, the Day of Judgment.

For my sins I studied German in Germany, and I rejoice to think that I have forgotten nearly every word of that raucous and obscene language. Had I a child to educate, and the choice between German and Choctaw were forced upon me, I should not select German. French, Italian, and Spanish, cognate tongues, easy to learn, delightful to speak, hold out sweet allurements to English children. Do not these suffice? If any mother who happens to read these lines is considering the propriety of teaching German to a daughter, let her weigh well the responsibility which she is deliberately assuming. To master any foreign language, it is necessary to talk much and often with the natives. Do Englishwomen wish to talk with any Huns after this war? What will be the feeling of an English mother whose daughter marries a Hun any time within the next twenty years? And such a mother will know that she planted the seed which ripened into catastrophe when she permitted her child to acquire the language of our detestable and detested enemies.

HORACE ANNESLEY VACHELL. 


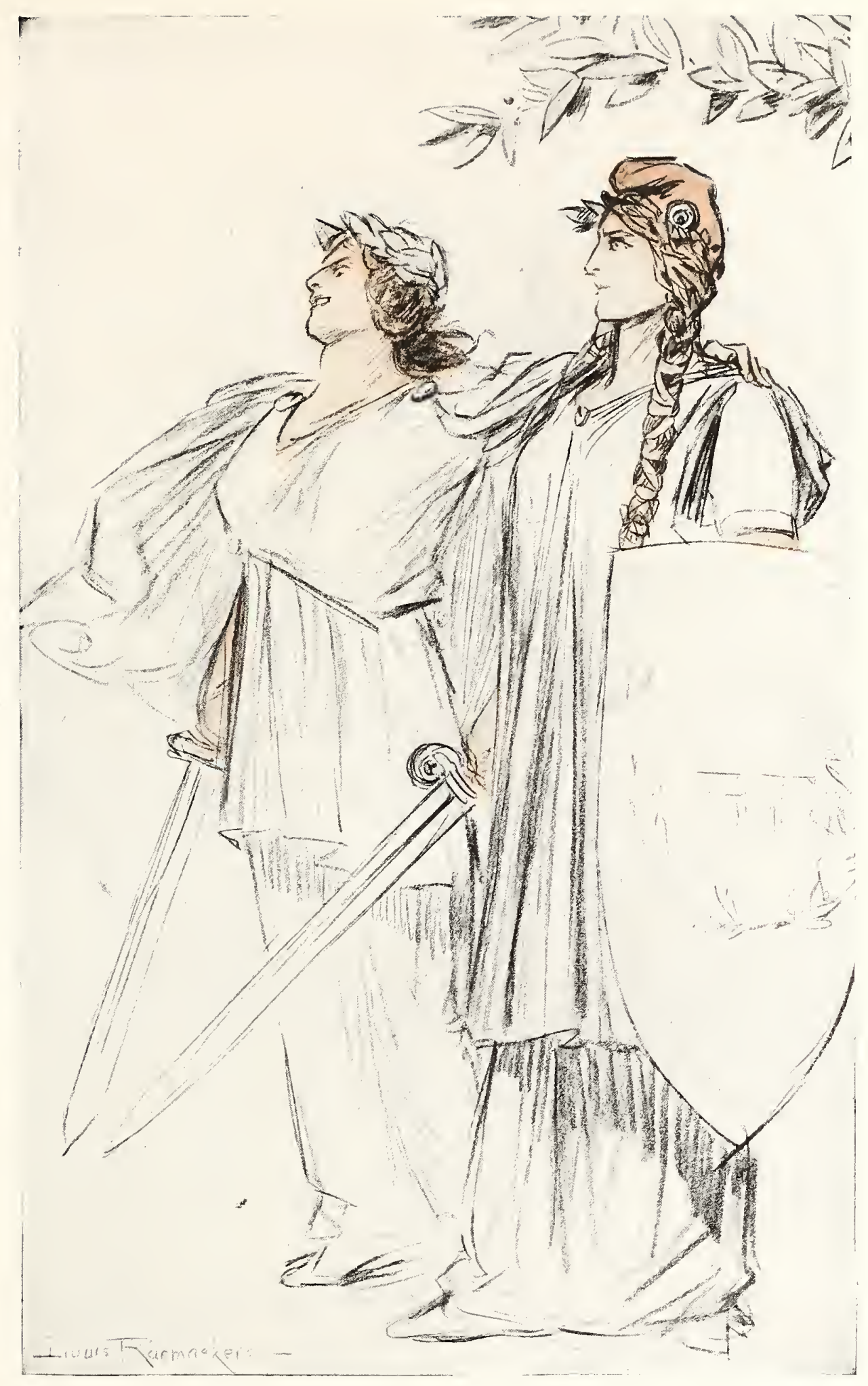

THE LATIN SISTERS

ITALY: "Indeed she is my sister." 


\section{Misunderstood}

T NEED not necessarily be supposed that the directors of German destiny, who are not devoid of intelligence, took the ravings of Bernhardi over-seriously. He had his special uses no doubt before the day. But on the morrow of the day, when questions of responsibility came to be raised, he became one of many inconvenient witnesses; and there has scarcely been a better joke among the grim humours of this catastrophe than the mission of this Redhot-Gospeller of the New Unchivalry of War to explain to "those idiotic Yankees" that he was really an ardent pacifist. The most just, the most brilliant, the most bitter pamphlet of invective could surely not say so much as this reeking cleaver, those bloody hands, that fatuous leer and gesture, this rigid victim. Bernhardism was not a mere windy theory. It was exactly practised on the Belgian people.

And this spare, dignified figure of Uncle Sam, contemptuously incredulous, is, I make bold to say, a more representative symbol of the American people than one which our impatience sometimes tempts us now to draw. Most Americans now regret, as Pope Benedict must regret, that the first most cruel rape of Belgium was allowed to pass without formal protest in the name of civilization. But that occasion gone, none other, not the Lusitania even, showed so clear an opportunity. A people's sentiments are not necessarily expressed by the action of its Government, which moves always in fetters. Nor has President Wilson's task been as simple as his critics on this or the other side of the Atlantic profess to believe.

JOSEPH THORP. 


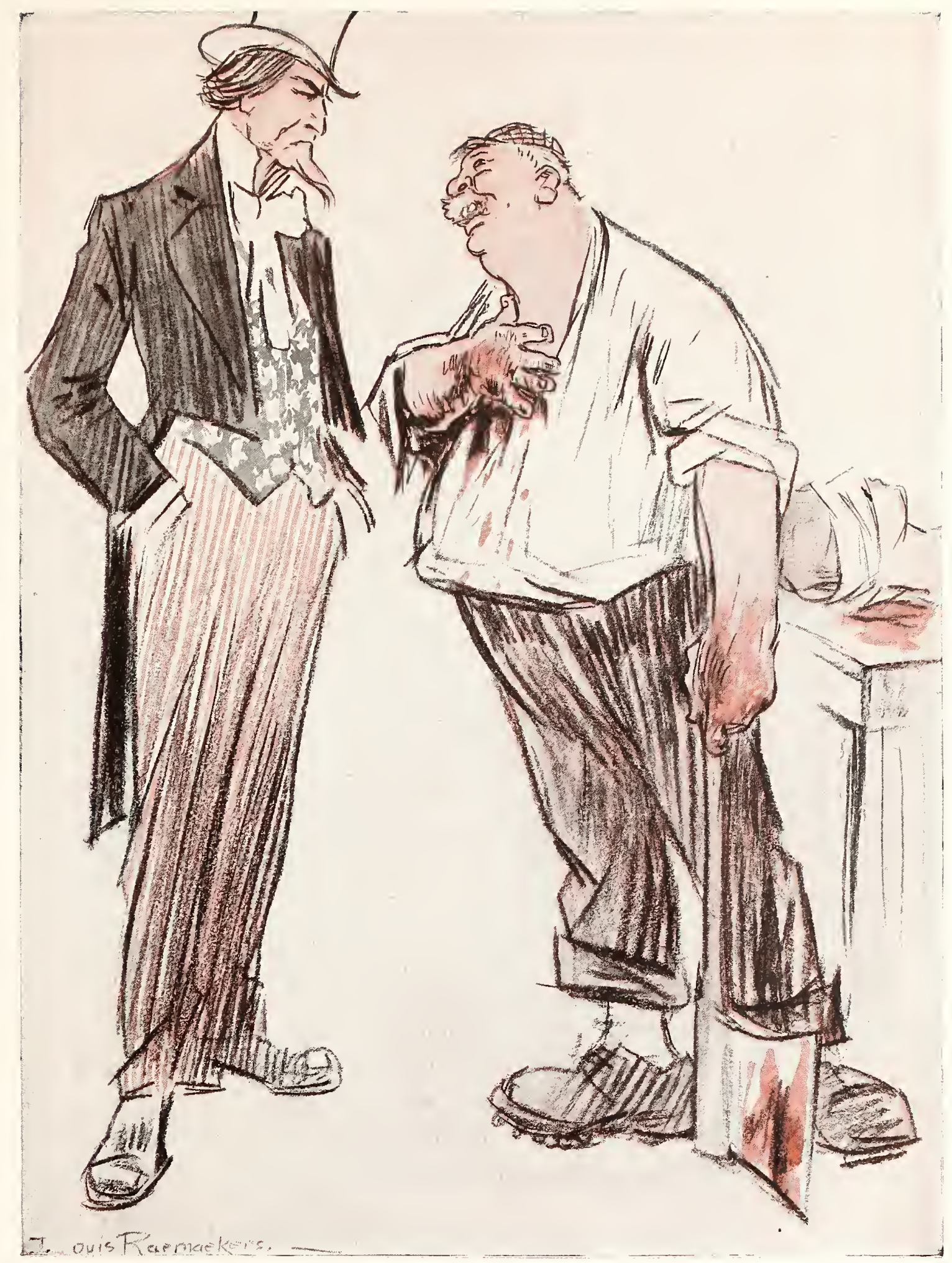

MISUNDERSTOOD

Bernhard: "Indeed I am the most humane fellow in the world." 


\section{Prosperity Reigns in Flanders}

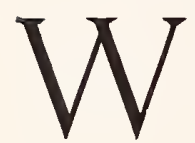

HEREVER Prussia rules she has only one method of rulingthat of terror. Wherever she finds civilization and the wealth which civilization creates, she can do nothing but despoil. She is as incapable of persuasion as of creation. No people forced to endure her rule have ever been won to prefer it as the Alsatians came to prefer the rule of France or as many-Indians have come to prefer the rule of England. In Belgium she has been especially herself in this respect.

A wise policy would have dictated such a careful respect for private rights and such a deference to native traditions as might conceivably have weakened the determination of the Belgians to resist to the death those who had violated their national independence. But Prussia is incapable of such a policy. In any territory which she occupies, whether temporarily or permanently, her only method is terror and her only aim loot. She did indeed send some of her-tame Socialists to Brussels to embark on the hopeless enterprise of persuading the Belgian Socialists that honour and patriotism were idéologies bourgeoises and that the "economic interests" of Belgium would be best promoted by a submission. These pedantic barbarians got the answer which they deserved; but on their pettifogging thesis Raemaekers' cartoon is perhaps the best commentary.

The "prosperity" of Belgium under Prussian rule has consisted in the systematic looting, in violation of international law, of the wealth accumulated by the free citizens of Belgium, for the advantage of their Prussian rulers; while to the mass of the people it has brought and, until it is forever destroyed, can bring nothing but that slavery which the Prussians have themselves accepted and which they would now impose upon the whole civilization of Europe.

CECIL CHESTERTON. 


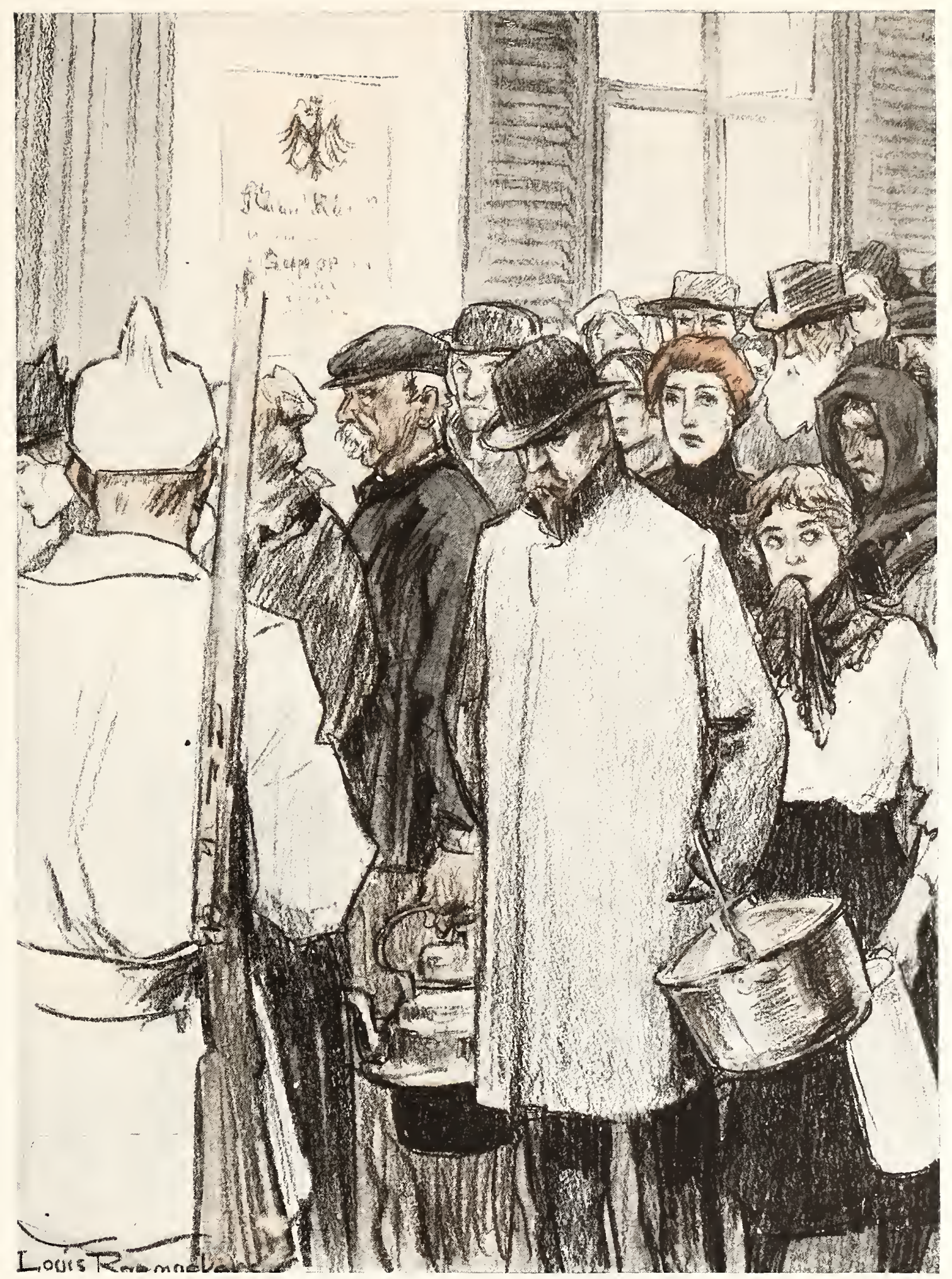

PROSPERITY REIGNS IN FLANDERS

Four hundred and eighty millions of francs have been imposed as a war tax, but soup is given gratis. 


\section{The Last Hohenzollern}

B EHIND him stands the embodiment of all that Prussian kultur and efficiency mean, wooden uninventiveness, clockwork accuracy of movement-without soul or inspiration. He himself is thin and scraggy-Raemaekers has intensified these characteristics, but even so the caricature of the reality is more accurate than unkind. Many months ago, this vacuous heir of the house of Hohenzollern set to work on the task of overcoming France, and the result.

may be found in bundles of four, going back to the incinerators beyond Aix, in the piled corpses before the French positions at and about Verdun; some of the results, the swag of the decadent burglar, went back in sacks from the châteaux that this despicable thing polluted and robbed as might any Sikes from Portland or Pentonville.

He is the embodiment, himself, of the last phase of Prussian kultur. Somewhere back in the history of Prussia its rulers had to invent and to create, and then kultur brought forth hard men; later, it became possible to copy, and then kultur brought forth mechanical perfection rather than creative perfection, systematized its theories of life and work, and brought into being a class of men just a little meaner, more rigid, more automaton-like, than the original class; having reduced life to one system, and that without soul or ideal, kultur brought forth types lacking more and more in originality. Here stands the culminating type; he will copy the good German Gott-he is incapable of originating anything - and will "do the same to France."

As far as lies in his power, he has done it; in the day of reckoning, Germany will judge how he has done it, and it is to be hoped that Germany will give him his just reward, for no punishment could be more fitting. The rest of the world already knows his vacuity, his utter uselessness, his criminal decadence. As his father was stripped of the Garter, so is he here shown stripped of the attributes to which, in earlier days, he made false claim. There remains a foolish knave posturing-and that is the real Crown Prince of Germany.

\section{E. CHARLES VIVIAN.}




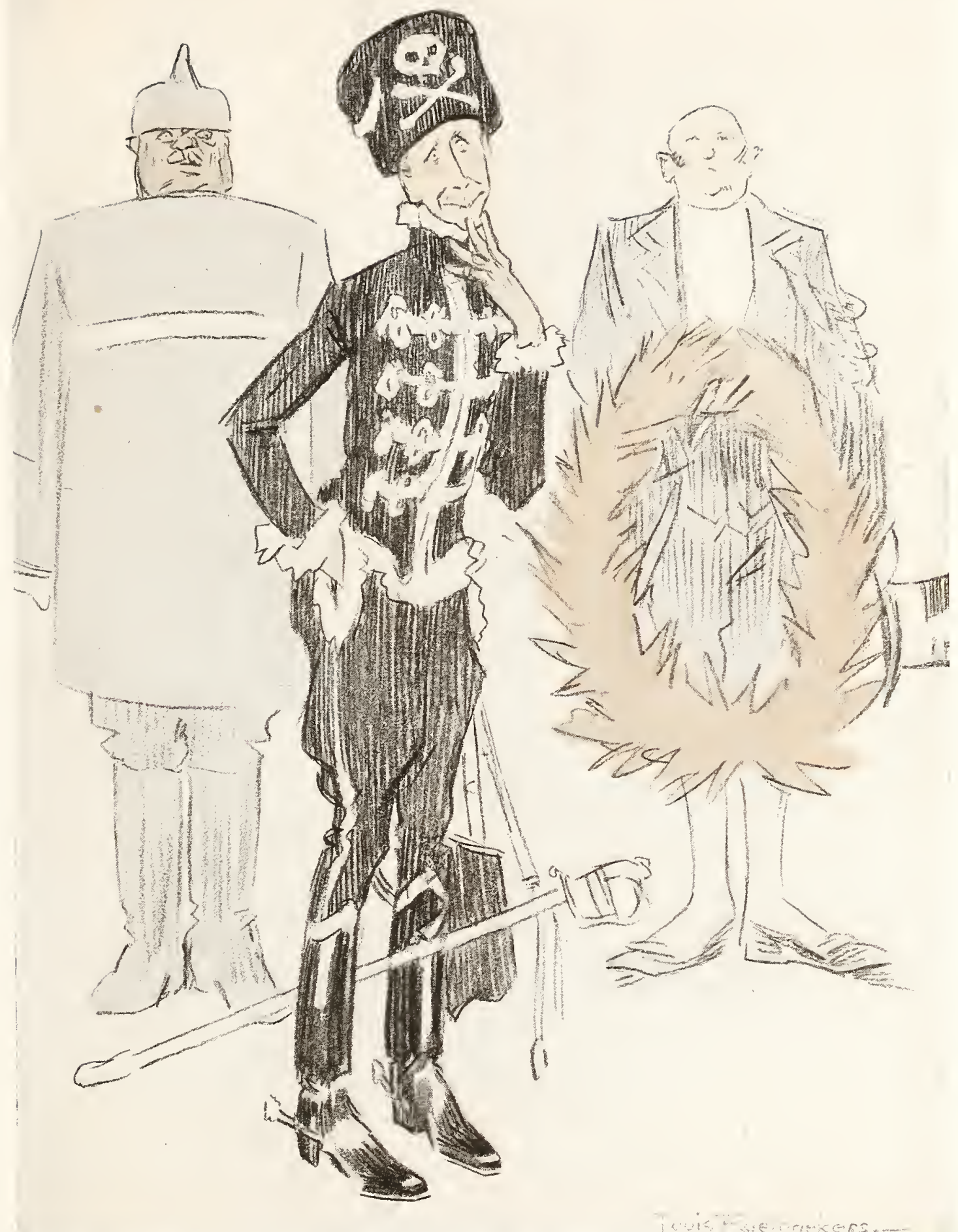

GOTT STRAFE ENGLAND!

"Father says I have to do the same with France." 


\section{Piracy}

T THE summer of 1914 Germany stood before the world, a nation of immense, and to a great extent of most honourable, achievement.

Her military greatness had never been in dispute. But in the previous twenty years she had developed an internal industry and an external commerce on a scale and with a rapidity entirely unprecedented. She had to build a navy such as no nation had ever constructed in so short a time. She seemed destined to progress in the immediate future as she had progressed in the immediate past.

What has the madness for world conquest done for her now? She has made enemies of all, and made all her enemies suffer. Like the strong blind man of history, she has seized the columns of civilization and brought the whole temple down. But has she not destroyed herself utterly amid the ruins? Her industry is paralyzed, her commerce gone. Her navy is dishonoured. Some force she still possesses at sea, but it is force to be expended on sea piracy alone. And it is not piracy that can save her. At most, in her extremity, it will do for her what a life belt does for a lone figure in a deserted ocean. It prolongs the agony that precedes inevitable extinction. It is the throw of the desperate gambler that Germany has made, when she flings this last vestige of her honour into the sea.

ARTHUR POLLEN。 


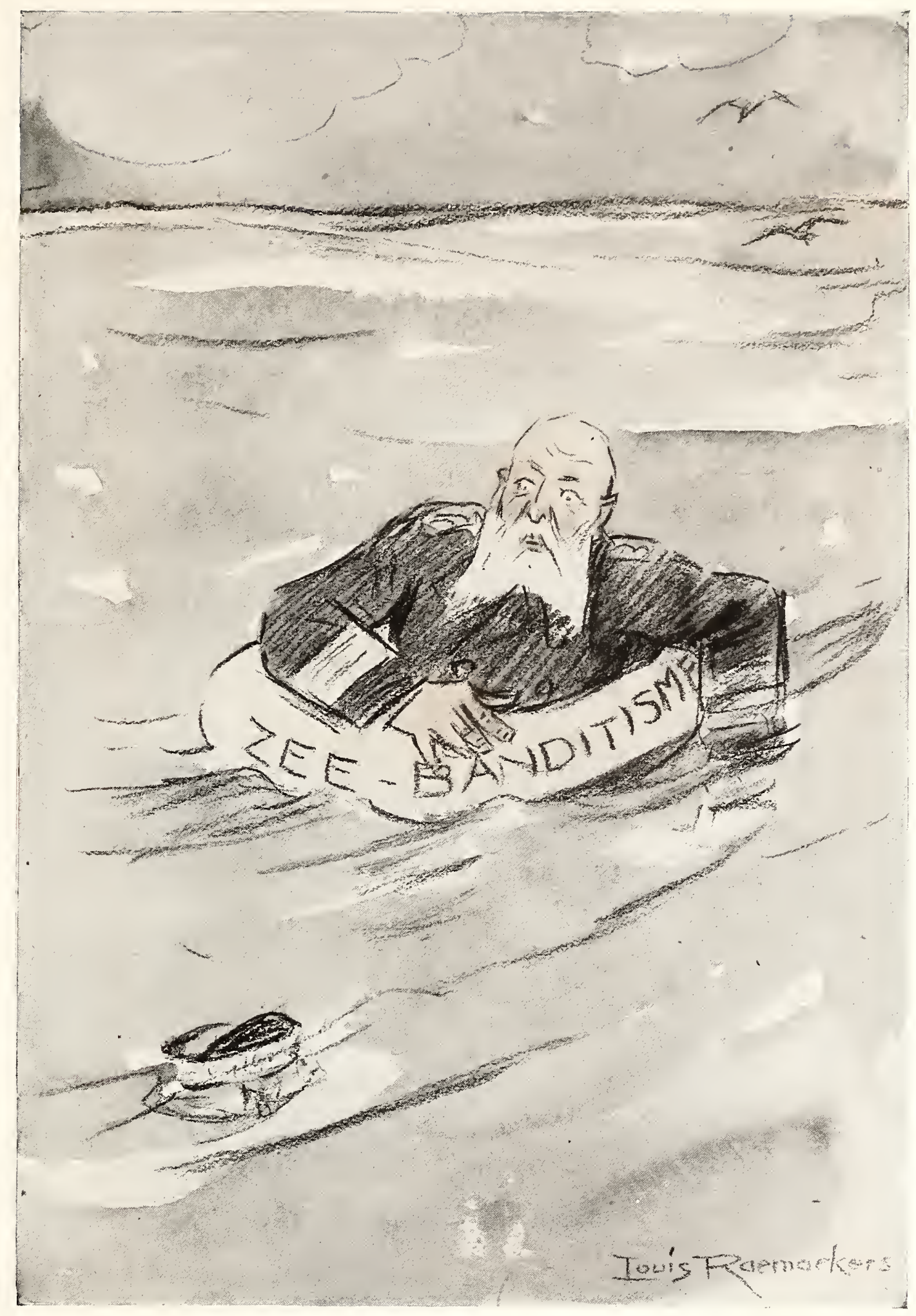

TIRPITZ'S LAST HOPE-PIRACY 


\section{"Weeping, She Hath Wept"}

W

HILE a world of mourners is plaintively asking, "What has become of our brave dead, where are they? Alas! how dark is the world without them, how silent the home, how sad the heart"; whilst the mourner is groping like the blind woman for her lost treasure, the Belgian mother, and the Belgian widow, and the Belgian orphan are on their knees, praying, "Eternal rest give to them, O Lord; let a perpetual light shine upon them," the Christian plea that has echoed down the ages from the day of the Maccabees till now, exhorting us to pray for the dead that they may be loosed from their sins.

I would remind the broken-hearted mother beseeching me to tell her where can her brave boy be gone, adding, "His was such a lonely journey; did he find his way to God?" of the words of the poet, who finds his answer to her question in the flight of a sea bird sailing sunward from the winter snows:

There is a Power whose care

Teaches thy way along the pathless coast, The desert and illimitable air,

Lone, wandering but not lost:

He who from zone to zone

Guides, through the boundless sky, thy certain flight,

In the lone way which thou must tread alone

IVill lead thy steps aright.

The brave soldier, who in the discharge of high duty has been suddenly shot into eternity by the fire of the enemy, will surely, far more easiny than the migrating bird, wing his flight to God, Who, let us pray, will not long withhold him the happy-making vision of Heaven. Pilgrims homeward-bound, as you readily understand, at different stages of their journey will picture Heaven to themselves differently, according as light or darkness, joy or sorrow encompass them. Some will picture Ileaven as the Everlasting Holiday after the drudgery of school life, others as Eternal Itappiness after a life of suffering and sorrow, others again as Home after exile, and some others as never-ending Rapture in the sight of God.

But to-day, when "frightfulness" is the creed of the enemy, and warfare with atrocities is his gospel, very many amongst us, weary with the long-drawn battle, sick with its ever-recurring horrors, and broken by its ghastly revelations, will lift up their eyes to a land beyond the stars.

FATHER BERNARD VAUGHAN. 


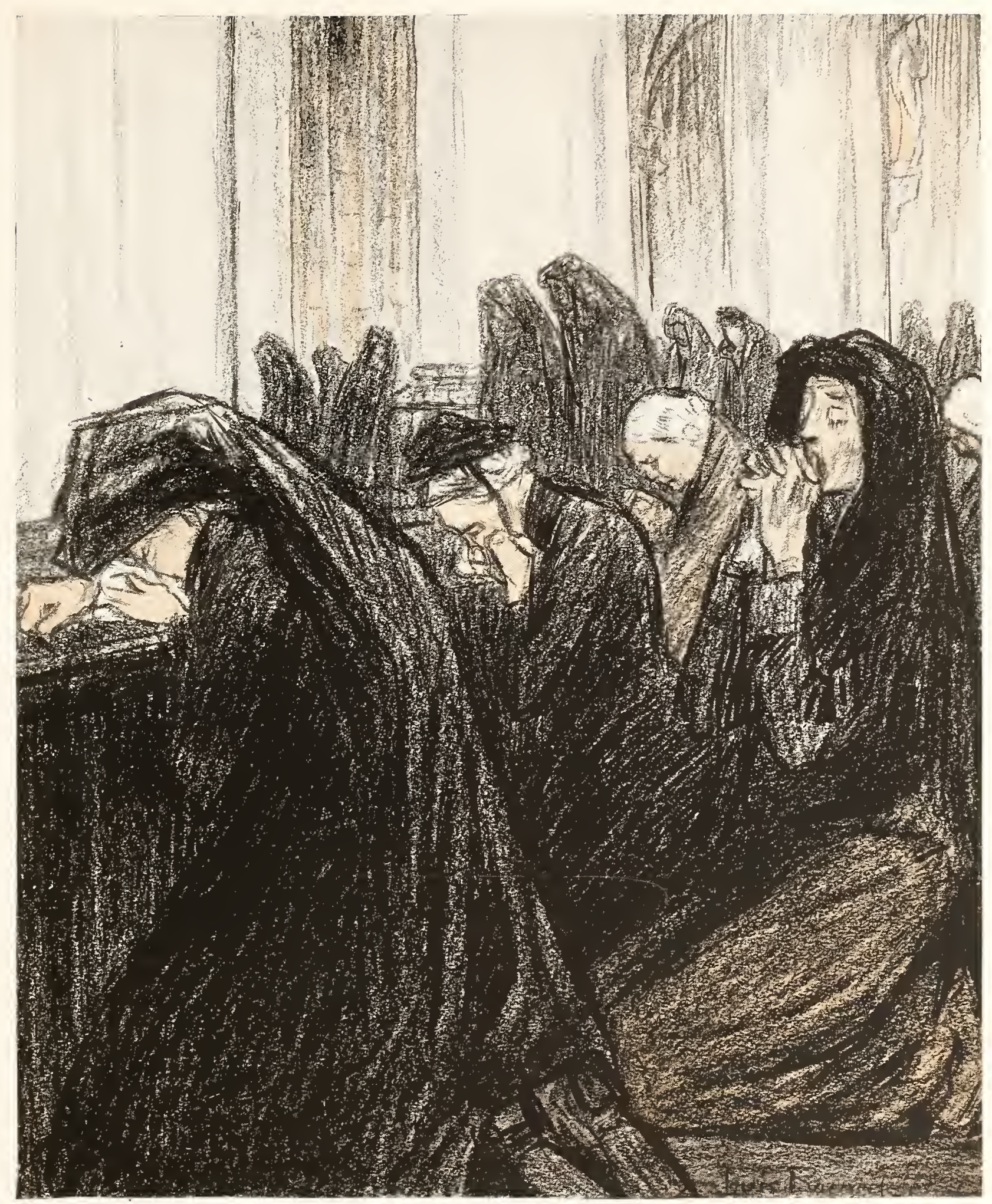

THE WIDOWS OF BELGIUM 


\section{Military Necessity}

TT MAY be asserted that the plea of "Frightfulness" will not be recognized a "military necessity" when Germany is judged, and I that this enemy of civilization, even as the enemy of society, will be held responsible for its crimes, though they stand as far above the imagination as beyond the power of a common felon. Bill Sikes may justly claim "military necessity" for his thefts and murders, if Germany can do so for hers.

Under Art'cle No. 46 of the Regulations of The Hague, we learn that "Family honour and rights, individual life and private property must be respected," and, under Article No 47, "all pillage is expressly forbidden." But while it was a political necessity to subscribe to that fundamental formula of civilization, Germany's heart recognized no real need to do so, and secretly, in cold blood, at the inspiration of her educated and well-born rulers, she plotted the details of a campaign of murder, rape, arson, and pillage, which demanded the breaking of her oath as its preliminary. Well might her Chancellor laugh at "the scrap of paper," which stood between Germany and Belgium, when he reflected on the long list of sacred assurances his perjured country had already planned to break.

No viler series of events, in Northern France alone, can be cited than those extracted from the note-books of captured and fallen Germans. Such blood-stained pages must be a tithe of those that returned to Germany, but they furnish a full story of what the rank and file accomplished at the instigation and example of their officers. Space precludes quotation; but one may refer the reader to "Germany's Violations of the Laws of War,"* published under the auspices of the French Foreign Office. It is a book that should be on the tables at the Peace Conference.

We cannol hang an army for these unspeakable offences, or treat those who burn a village of living beings as we would treat one who made a bonfire of his fellow-man; nor can we condemn to penal servitude a whole nation for bestial outrages on humanity, ordered by its Higher Command and executed by its troops; but at least we may hope soon to find the offending Empire under police supervision of Europe, with a ticket-of-leave, whose conditions shall be as strict as an outraged earth knows how to draw them.

EDEN PHILLPOTTS.

*English translation. Heinemann. 


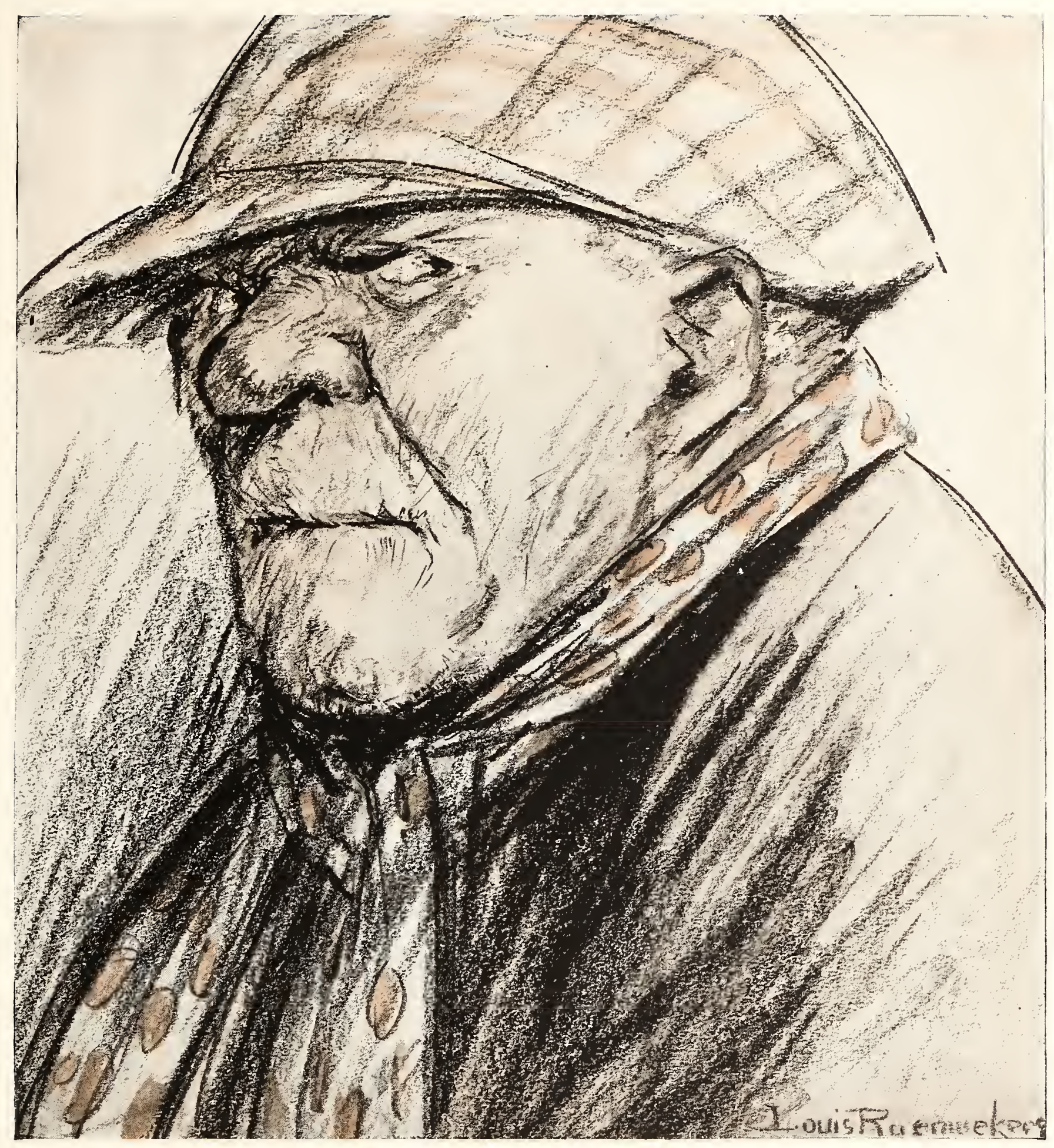

ON TICKET-OF-LEAVE

Convict: "The next time I'll wear a German helmet and plead 'military necessity," 


\section{Liberté! Liberté, Chérie!}

T

HERE have been many surprises in this war. The evil surprises, patiently, scientifically, diabolically matured in the dark for the upsetting and downcasting of a too-trusting world by the enemy of mankind, whose "Teuton-faith" will surely forever outrival that "Punic-faith" which has hitherto been the by-word for perfidious treachery. The heartening surprises of gallant little Belgium and Serbia; the renascence of Russia; the wonderful upleap to the needs of the times by Great, and still more by Greater Britain; and, not least, the bracing of the loins of our closest Allies just across the water.

In the very beginning, when the Huns tore up that scrap of paper which represented their honour and their right to a place among decent dwellers on the earth, and came sweeping like a dirty flood over Belgium and Northern France, the overpowering remembrance of 1870 still lay heavy on our sorely-tried neighbours. They had not yet quite found themselves. The Huns had a mighty reputation for invincibility. It seemed impossible to stand against them. There were waverings, even crumplings. There were said to be treacheries in high places.

The black flood swept on. Von Kluck was heading for Paris, and seemed likely to get there. Then suddenly, miraculously as it seemed, his course was diverted. He was tossed aside and flung back.

And it is good to recall the reason he himself is said to have given for his failure.

"At Mons the British taught the French how to die."

That is a great saying and worthy of preservation for all time. Whether Von Kluck said it or not does not matter. It represents and immortalizes a mighty fact.

France was bending under the terrible impact. Britain stood and died. France braced her loins and they have been splendidly braced ever since.

The Huns were found to be resistible, vulnerable, breakable. The old verve and élan came back with all the old fire, and along with these, new depths of grim courage and tenacity, and, we are told, of spirituality, which may be the making of a new France greater than the world has ever known.

And that we shall welcome. France, Belgium, Serbia, Russia have suffered in ways we but faintly comprehend on this side of the water. When the Great Settling Day comes, this new higher spirit of France will, it is to be devoutly hoped, make for restraint in the universal craving for vengeance, and prove a weighty factor in the righteous re-adjustment of things and the proper fitting together of the jig-saw map of Europe.

JOHN OXENHAM. 


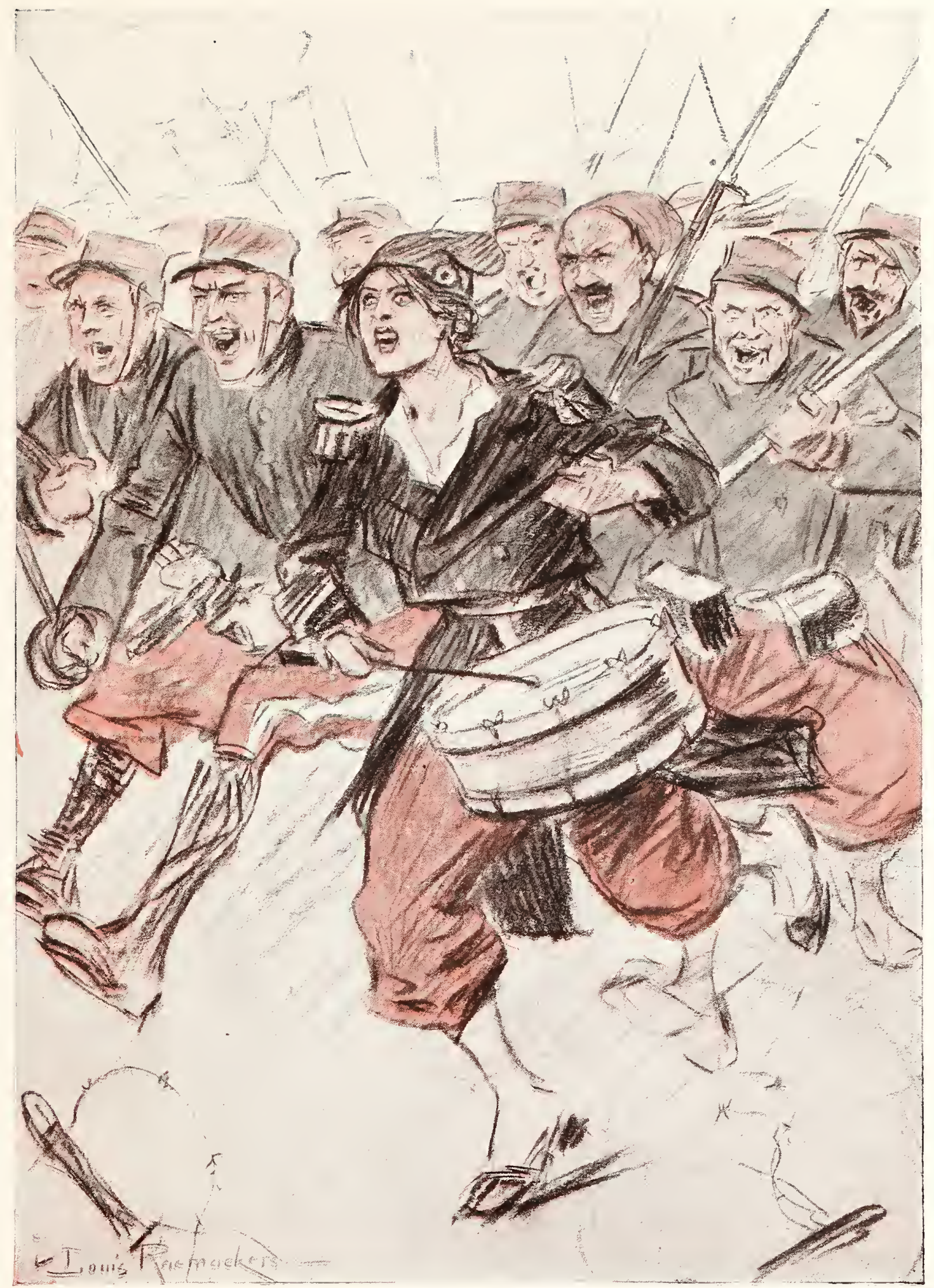

LIBERTÉ！ LIBERTÉ, CHERIE! 


\section{I-"A Knavish Piece of Work"}

THERE can be no defence of the spirit of hatred in which the Germans have, so fatally for their future, carried on this amazing mad war of theirs, in violation of all human instincts of self-respect and self-preservation, to say nothing of the obligations of religion and morality observed among mankind from the first dawnings of civilization. The knavery, the villainy, and the besotted bestiality of it can never be forgotten, and must never be forgiven, and Louis Raemaekers, gifted as he is with the rare dramatic genius that discriminates his Cartoons, has but discharged an obvious patriotic duty in publishing them to the world at large, as true and faithful witnesses to the unspeakable and inexpiable abominations wrought throughout Belgium and French Flanders by the Germans - which, already, in the course of Divine retribution, have involved their own country in material losses it will take from three to four generations to repair; and their once honoured name in contempt, and reprobation, and infamy, wherefrom it can never be redeemed.

Nevertheless, as an Englishman, I shrink from giving any emphasis there may be in my "hand and signature" to these righteously condemnatory and withering cartoons; and because, each one of them, as I turn to it, brings more and more crushingly home to me the transcending sin of England - of every individual Englishman with a vote for Members of Parliament - in not having prepared for this war; a sin that has implicated us in the destruction of the whole rising generation of the flower of our manhood; and, before this date, would have brought us under subjection to Germany but for the confidence placed by the rank and file of the British people and nation in Lord Kitchener of Khartum.

Now-face to face with enemies - from the Kaiser downward to his humblest subjects - animated by the highest, noblest ideals, but again perverted for a time-as in the case of their ancestors in the Middle Ages-by a secular epidemic of "Panmania," they are to be faced not with idle reproaches and revilings, still less with undignified taunts and gibes, but with close-drawn lips and clenched teeth, in the determination that, once having cast Satan out of them, he shall be bound down to keep the peace of Christendom- "for a thousand years."

GEORGE BIRDWOOD. 


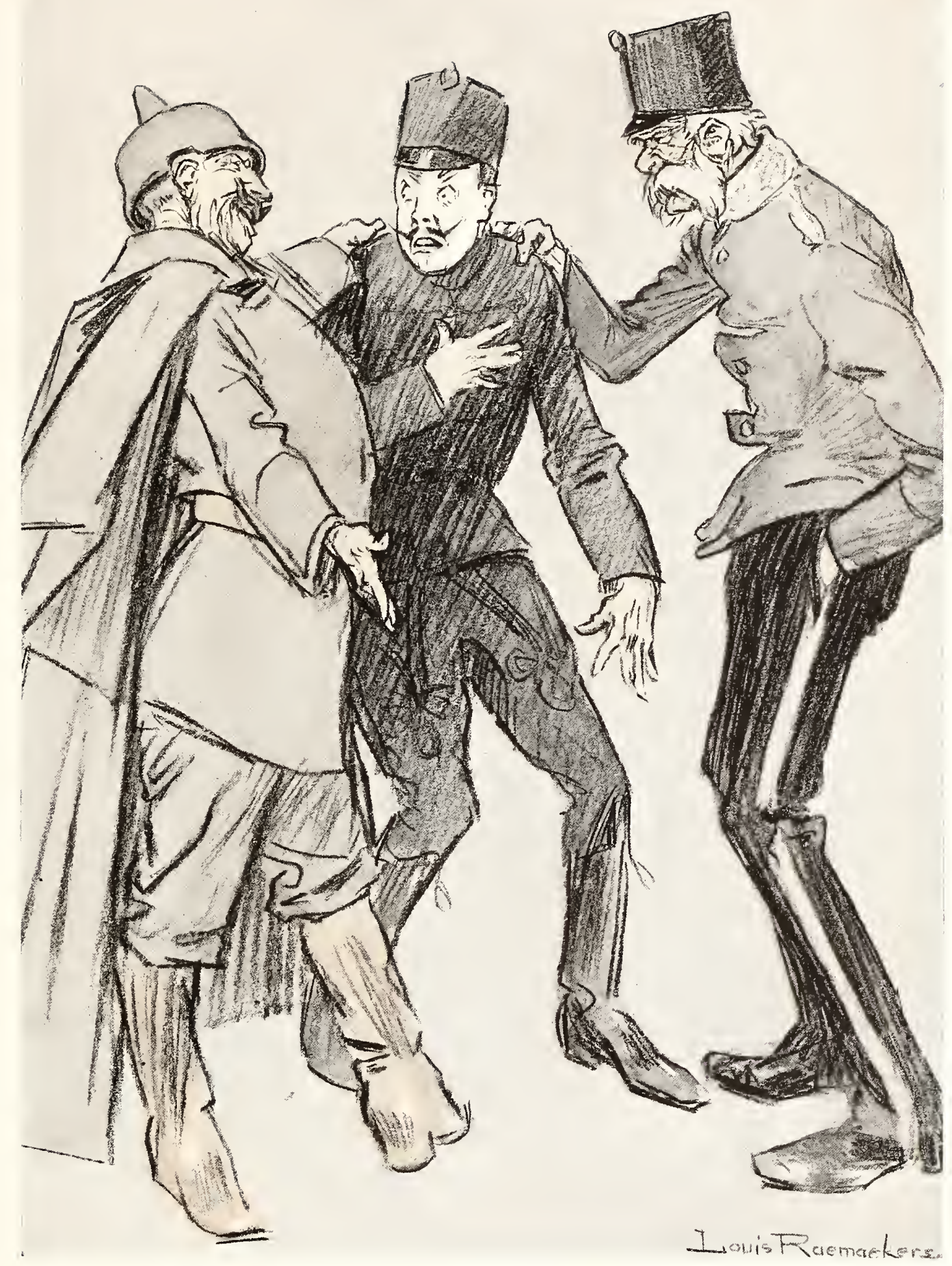

WE'LL GIVE YOU THE TITLE OF MPRET OF POLAND

The new Governor has had the title of Mpret given to him, the same that was given to the ill-starred Prince of Wied when made ruler of Albania in 1914. 


\section{II-"Sisyphus,_His Stone"}

S

ISYPHUS, as the story goes, was a King who widely extended the commerce, and largely increased the wealth, of Corinth, but by avaricious and fraudful ways; for the sin whereof he was sentenced after death to the unresting labour of rolling up a hill in Tartarus, a huge unhewn block of stone, which so soon as he gets it to the hill top, for all his efforts, rolls down again. In classical representation of the scene he is associated with Tantalus and Ixion; Tantalus, who, presuming too much on his relations with Zeus, was after death afflicted with an unquenchable thirst amidst flowing fountains and pellucid lakes - like the lakes of "The Thirst of the Antelope" in the marvellous mirages of Rajputana and Mesopotamia - that ever elude his anguished approaches; and with Ixion, the meanest and basest of cheats, and most demoniac of murderers, whose posthumous punishment was in being stretched, and broken, and bound, in the figure of the svastika, on a wheel which, self-moved-like the wheels of the vision of Ezekiel-whirls forevermore round and round the abyss of the nether world. The moral of these tortures is that we may well and most wisely leave vengeance to "the high Gods." They will repay!

GEORGE BIRDWOOD. 


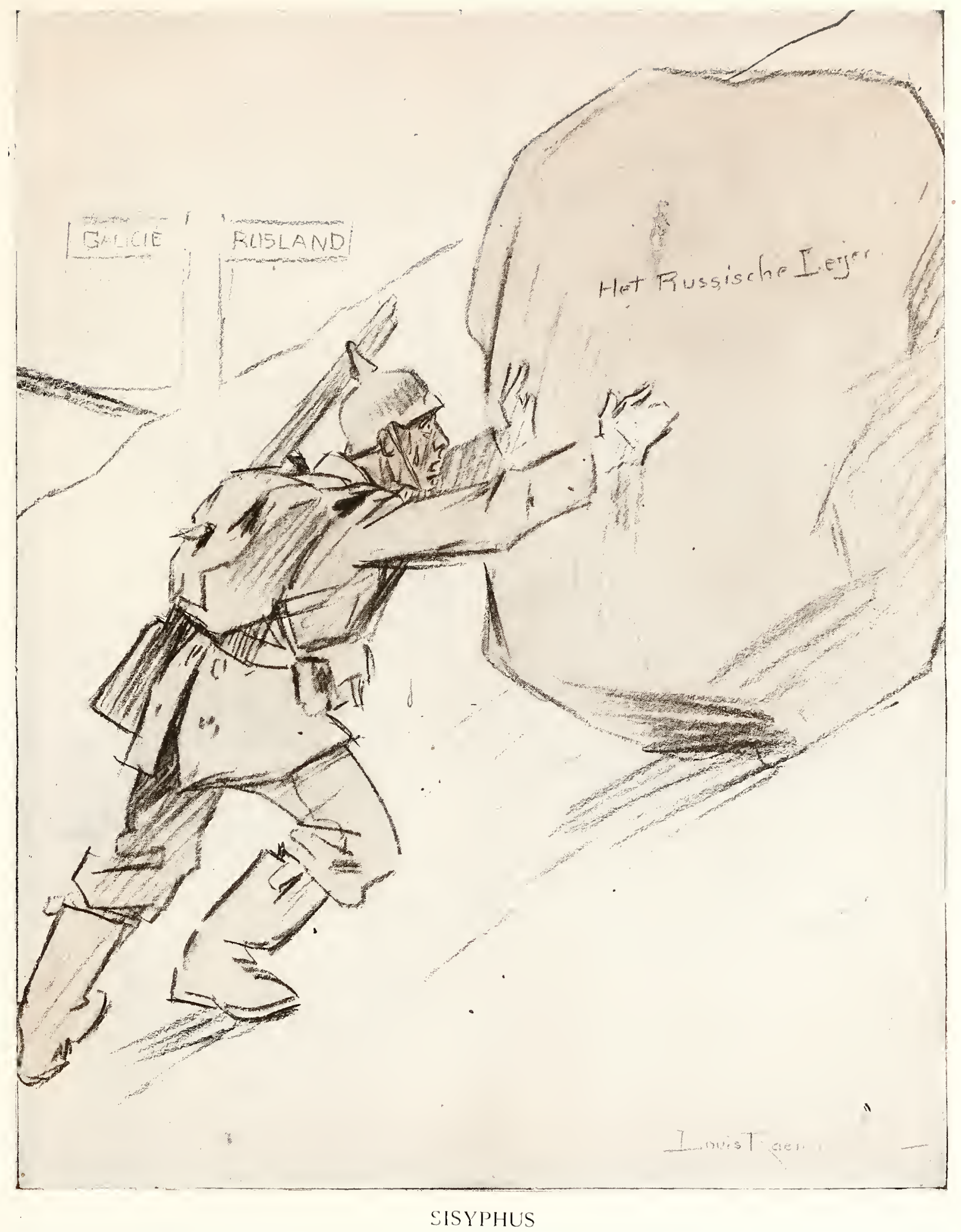




\section{Concrete Foundations}

$\mathrm{N}$

OTHING has damned the Germans more in the eyes of other nations, belligerent and neutral alike, and nothing will have a more subtle and lasting influence on future relations, than the revelation of stealthy preparation for conquest under a mask of innocent and friendly intercourse. The whole process of "peaceful penetration," pursued in a thousand ways with infernal ingenuity and relentless determination, is an exhibition of systematic treachery such as all the Macchiavellis have never conceived. Germany has revealed herself as a nation of spies and assassins. To take advantage of a neighbour's unsuspecting hospitality, to enter his house with an air of open friendship, in order to stab him in the back at a convenient moment, is an act of the basest treachery, denounced by all mankind in all ages. No one would be more shocked by it in private life than the Germans themselves. But when it is undertaken methodically on a national scale under the influence of Deutschland über Alles, the same conduct becomes ennobled in their eyes, they throw themselves into it with enthusiasm and lose all sense of honour. Such is the moral perversion worked by Kultur and the German theory of the State.

An inevitable consequence is that in future the movements and proceedings of Germans in other countries will be watched with intense suspicion, and if Governments do not prevent the sort of thing depicted by Mr. Raemaekers the people will see to it themselves. The cartoon is not, of course, intended to reflect personally on the owner of Krupp's works, who is said to be a gentle-minded and blameless lady. It is her misfortune to be associated by the chance of inheritance with the German war machine and one of the underhand methods by which it has pursued its aims.

A. SHADWELL. 


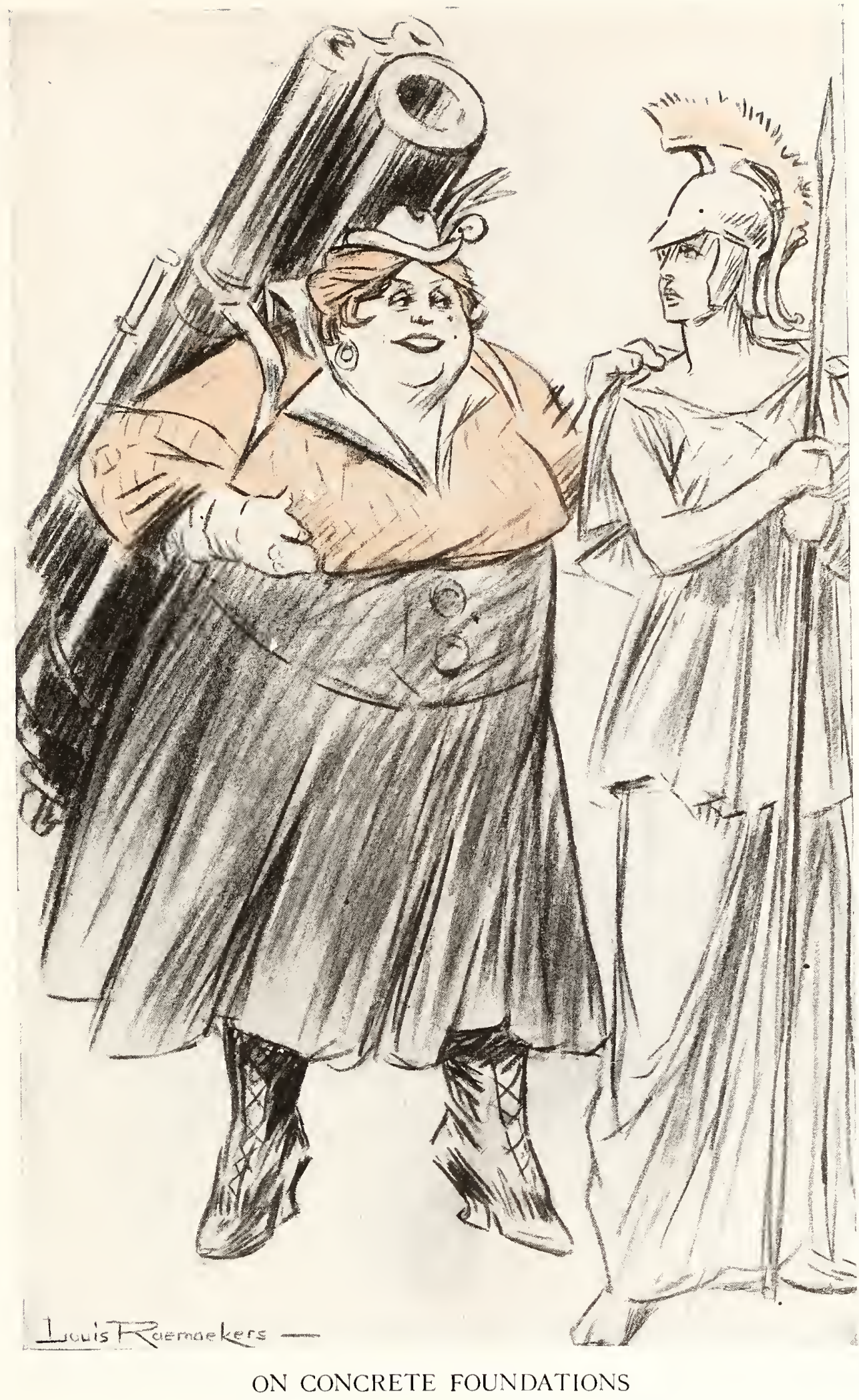

Big Bertha: "What a charming view over Flushing harbour! May I build a villa here?" 


\section{Pallas Athene}

$\mathrm{H}$ AS it come to this?" Well may the Goddess ask this question. Times are indeed changed since the heroic days. Germany has still her great Greek scholars, one or two of them among the greatest living. men who know, and can feel, the spirit, as well as the letter, of the old Classics. Do they remember today what the relation of the Goddess of Wisdom was to the God of War, in Homer, when, to use the Latin names which are perhaps more familiar, to the general reader than the Greek, Mars "indulged in lawless rage," and Jove sent Juno and Minerva to check his "frightfulness?"

"Go! and the great Minerva be thine aid;

To tame the monster-god Minerva knows,

And oft afflicts his brutal breast with woes."

and how the hero Diomede, with Minerva's aid, wounded the divine bully and sent him bellowing and whimpering back, only to hear from his father the just rebuke:

"To me, perfidious! this lamenting strain?

Of lawless force shall lawless Mars complain?

Of all the gods who tread the spangled skies,

Thou most unjust, most odious in our eyes!

Inhuman discord is thy dear delight,

The waste of slaughter, and the rage of fight!"

It is most true. Such has ever been War for War's sake, and when the Germans themselves are wounded and beaten, they complain like Mar's of old of "lawless force."

But Raemaekers has introduced another touch more Roman than Greek, and reminding us perhaps of Tacitus rather than of Homer.

Who was Caligula, and what does his name mean? "Little Jack-boots," in his childhood the spoiled child of the camp, as a man, and Cæsar, the first of the thoroughly mad, as well as bad, Emperors of Rome, the first to claim divine honours in his lifetime, to pose as an artist and an architect, an orator and a litlérateur, to have executions carried out under his own eyes, and while he was at meals; who made himself a God, and his horse a Consul.

Minerva blacking the boots of Caligula - it is a clever combination!

But there is an even worse use of Pallas, which WVar and the German War-lords have made. They have found a new Pallas of their own, not the supernal Goddess of Heavenly Wisdom and Moderation, but her infernal counterfeit, sung of by a famous English poet in prophetic lines that come back to us to-day with new force.

Who loves not Knowledge, who shall rail

Against her beauty, may she mix

With men and prosper, who shall fix

Her pillars? let her work prevail.

Yes, but how do the lines continue?

What is she cut from love and faith

But some wild Pallas from the brain

Of Demons, fiery hot to burst

All barriers in her onward race

For power? Let her know her place,

She is the second, not the first.

Knowledge is power, but, unrestrained by conscience, a very awful power.

This is the Pallas whom the "Demons," from whose brain she has sprung, are using for their demoniac purposes. She too might have her portrait painted-and they. Perhaps Raemaekers will paint them both before he has done.

HERBERT WARNER. 


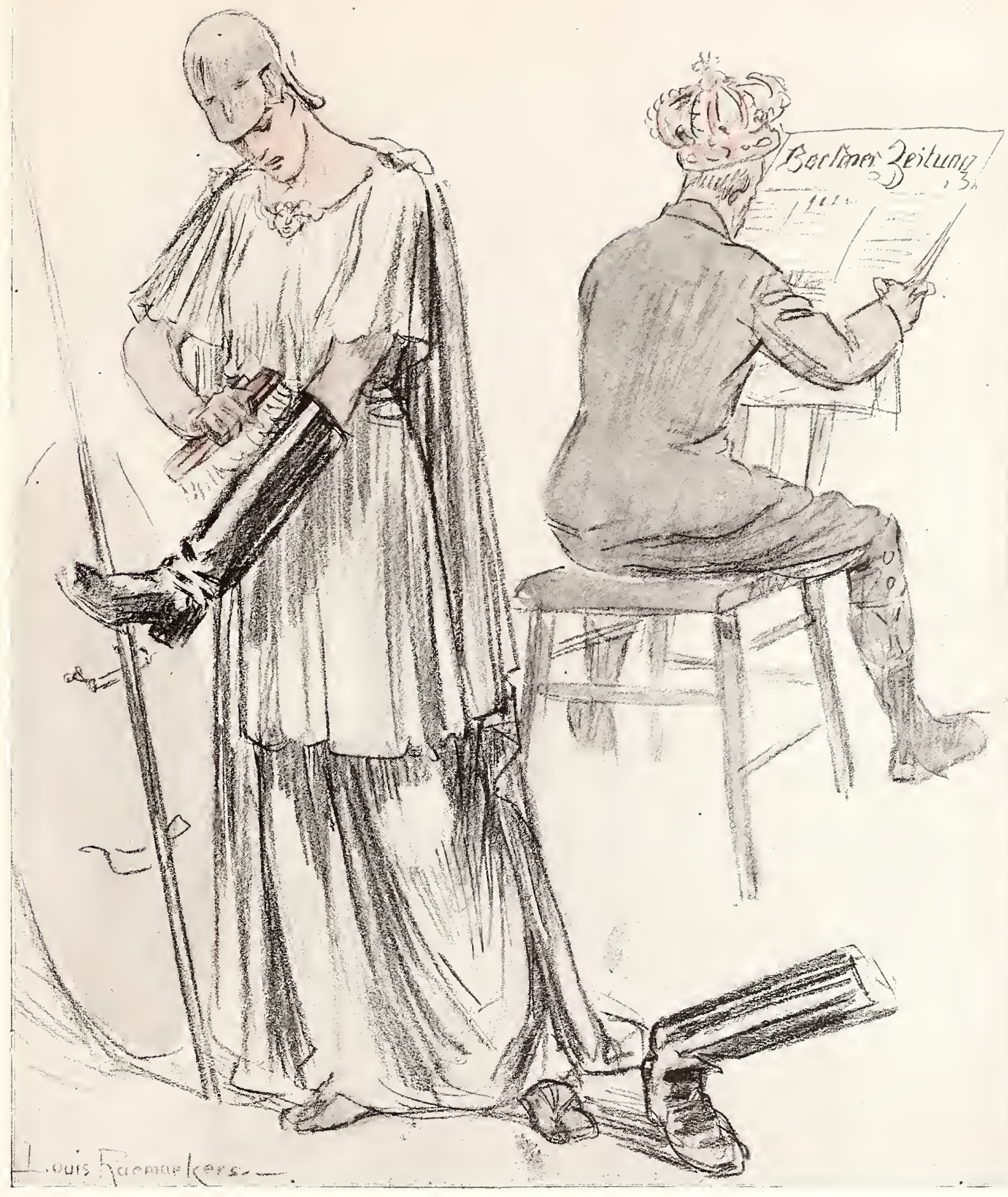

Pallas Athene: "Has it come to this?" 


\section{The Wonders of Culture}

$\mathrm{O}$ F ALL forms of "Kultur" or "frightfulness" that which materializes in the "the terror which flieth by night" is to the intelligent mind at one and the same time the most insensate and damnable. It fails to accomplish, either in Paris or in London, the subjugation by terror of the people for which Germans seem to hope. It is only in German imagination that it accomplishes "material and satisfactory damage to forts, camps, arsenals, and fortified towns." In reality it inflicts misery and death upon a mere handful of people (horrible as that may be) and destroys chiefly the homes of the poor. It serves no military end, and the damage done is out of all proportion to the expenditure of energy and material used to accomplish it.

The fine cartoon which Raemaekers has drawn to bring home to the imagination what this form of "Kultur" stands for makes it easy for us in London to sympathize with our brothers and sisters in Paris. We have as yet been spared daylight raids in the Metropolitan area, and so we needed this cartoon to enable us to realize fully what "Kultur" by indiscriminate Zeppelin bombs means.

Who cannot see the cruel drama played out in that Paris street? The artist has assembled for us in a few living figures all the actors. The dead woman; the orphaned child, as yet scarcely realizing her loss; the bereaved workman, calling down the vengeance of Heaven upon the murderers from the air; the stern faces of the sergents de ville, evidently feeling keenly their impotence to protect; and in the background other sergents, the lines of whose bent backs convey in a marvellous manner and with a touch of real genius the impression of tender solicitude for the injured they are tending. And faintly indicated, further still in the background, the crowd that differs little, whether it be French or English, in its deeper emotions.

CLIVE HOLLAND. 


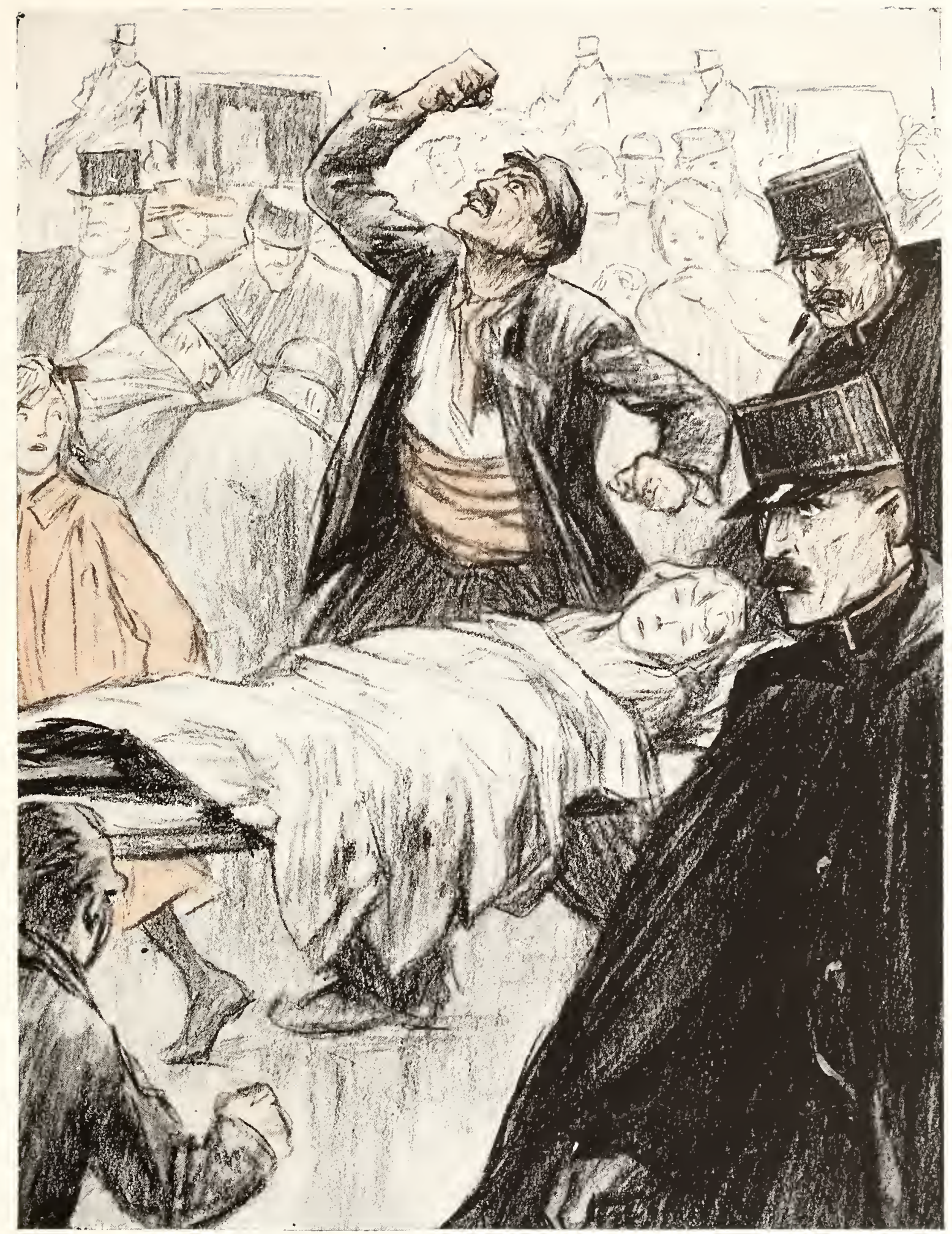

THE WONDERS OF CULTURE 


\section{"Folk Who Do Not Understand Them"}

$\mathrm{H}$

OW often have I been asked by sorrow-stricken mothers and wives: "Why does not Providence intervene either to stop this war, or at least to check its cruelties and horrors?" If for many amongst us not yet bereaved this European massacre is a puzzle, it should not cause us dismay or surprise, if the widow or son-bereaved mother lifts up her hands exclaiming: "Why did not God save him? Why did He let him be shot down by those Huns?'

Truth to tell, God has, so to speak, tied up His own hands in setting ours free. When He placed the human race upon the surface of this planet He dowered them with freedom, giving to each man self-determining force, by the exercise of which he was to become better than a man or worse than a beast. Good and evil, like wheat and cockle, grow together, in the same field. The winnowing is at harvesttime, not before. Meanwhile, we ourselves have lived to see the fairest portions of this fair creation of God changed from a garden into a desert-pillaged, ravaged, and brought to utter ruin by shot and shell, sword and fire. When I have said this, I have but uttered a foreword to the hideous story, spoken the prologue only of the "frightful" tragedy. We are all familiar with at least some of the revolting facts and details with which the German soldiery has been found charged and convicted by Commissions appointed to investigate the crimes and atrocities adduced against them. The verdicts of French, Belgian, and English tribunals are unanimous. They all agree that Germany has been caught redhanded in her work of dyeing the map of Europe red with innocent blood.

When you bend your eyes to the pathetic cartoon standing opposite this letterpress, is there not brought home to you in a way, touching even to tears, the "frightful" consequences of the misuse of human powers, more especially of the attribute of freedom? If Germany had chosen to use, instead of brute force, moral force, what a great, grand, and glorious mission might have been hers to-day. If, instead of trying the impossible task of dominating the whole world with her iron hand upon its throat and her iron heel upon its foot, she had been satisfied with the portion of the map already belonging to her, and had not by processes of bureaucratic tyranny driven away millions of her subjects who preferred liberty to slavery, America to Germany, by this date she might have consolidated an Empire second in the world to none but one. Alas! in her over-reaching arrogance she has, on the contrary, set out to de-Christianize, de-civilize, and even de-humanize the race for which Christ lived and died.

Our high mission it is to try to save her from herself. Already I can read written in letters of blood carved into the gravestone of her corrupted greatness,

"lll-weaved ambition,

How much art thou shrunk!"

BERNARD VAUGHAN. 


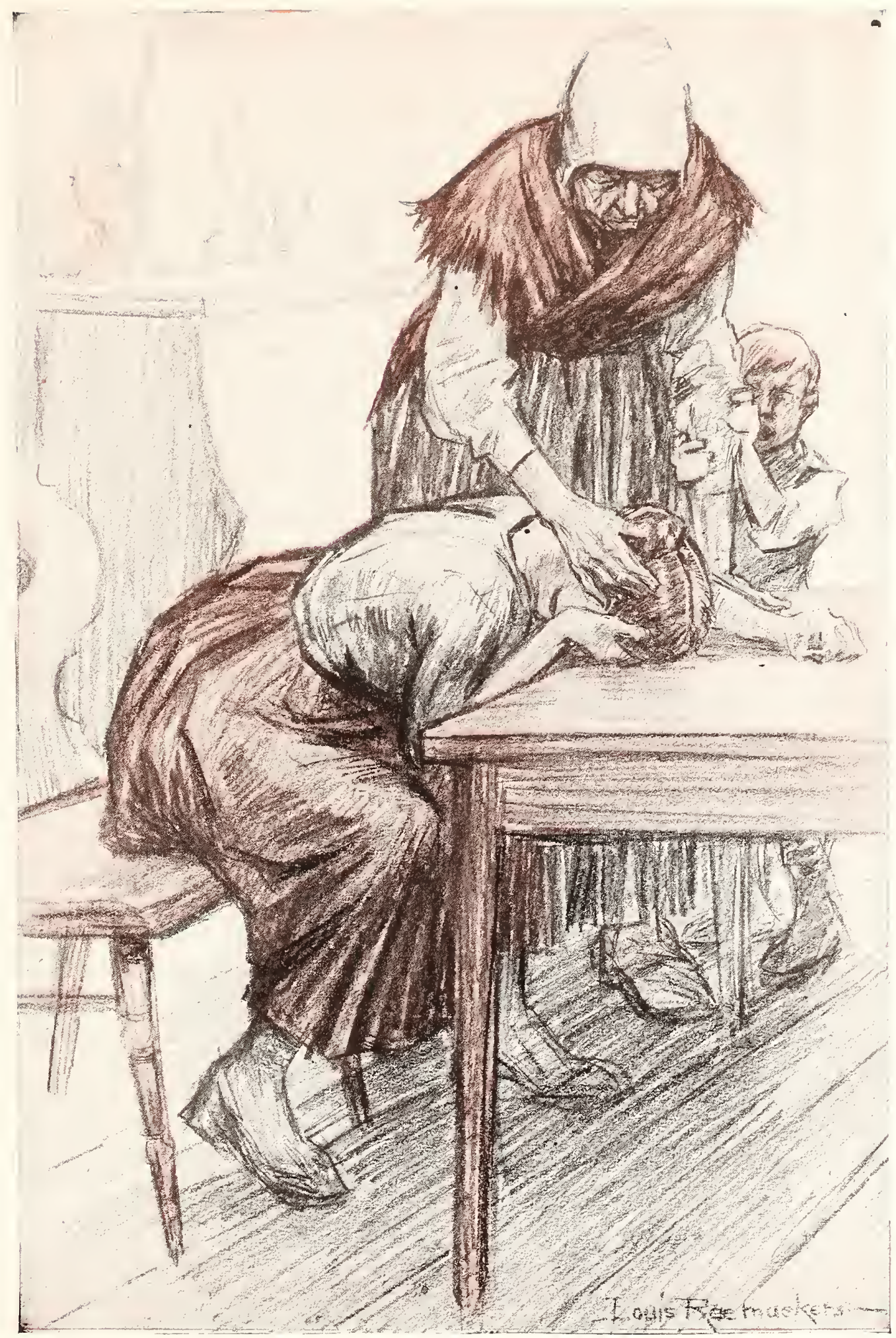

LES BEAUTES DE LA GUERRE

Folk who do not understand them. 


\section{On the Way to Calais}

HEY are coming, like a tempest, in their endless ranks of gray, While the world throws up a cloud of dust upon their awful way; They're the glorious cannon fodder of the mighty Fatherland, Born to make the kingdoms tremble and the nations understand.

Tramp! Tramp! Tramp! the cannon fodder come Along their way to Calais; (God help the hearth and home.) They'll do his will who taught them, on the earth and on the waves, Till land and sea are festering with their unnumbered graves.

The garrison and barrack and the fortress give them vent; They sweep, a herd of winter wolves, upon the flying scent; For all their deeds of horror they are told that death atones, And their master's harvest cannot spring till he has sowed their bones.

Into beasts of prey he's turned them; when they show their teeth and growl

The lash is buried in their cheeks; they're slaughtered if they howl;

To their bloody Lord of Battles must they only bend the knee, For hard as steel and fierce as hell should cannon fodder be.

Scourge and curses are their portion, pain and hunger without end, Till they hail the yell of shrapnel as the welcome of a friend;

They drink and burn and rape and laugh to hear the women cry, And do the devil's work to-day, but on the morrow die.

Drift! Drift! Drift! the cannon fodder go

Upon their way to Calais, (God feed the carrion crow.)

They've done his will who taught them that the Germans shall be slaves,

Till land and sea are festering with their unnumbered graves.

EDEN PHILLPOTTS. 


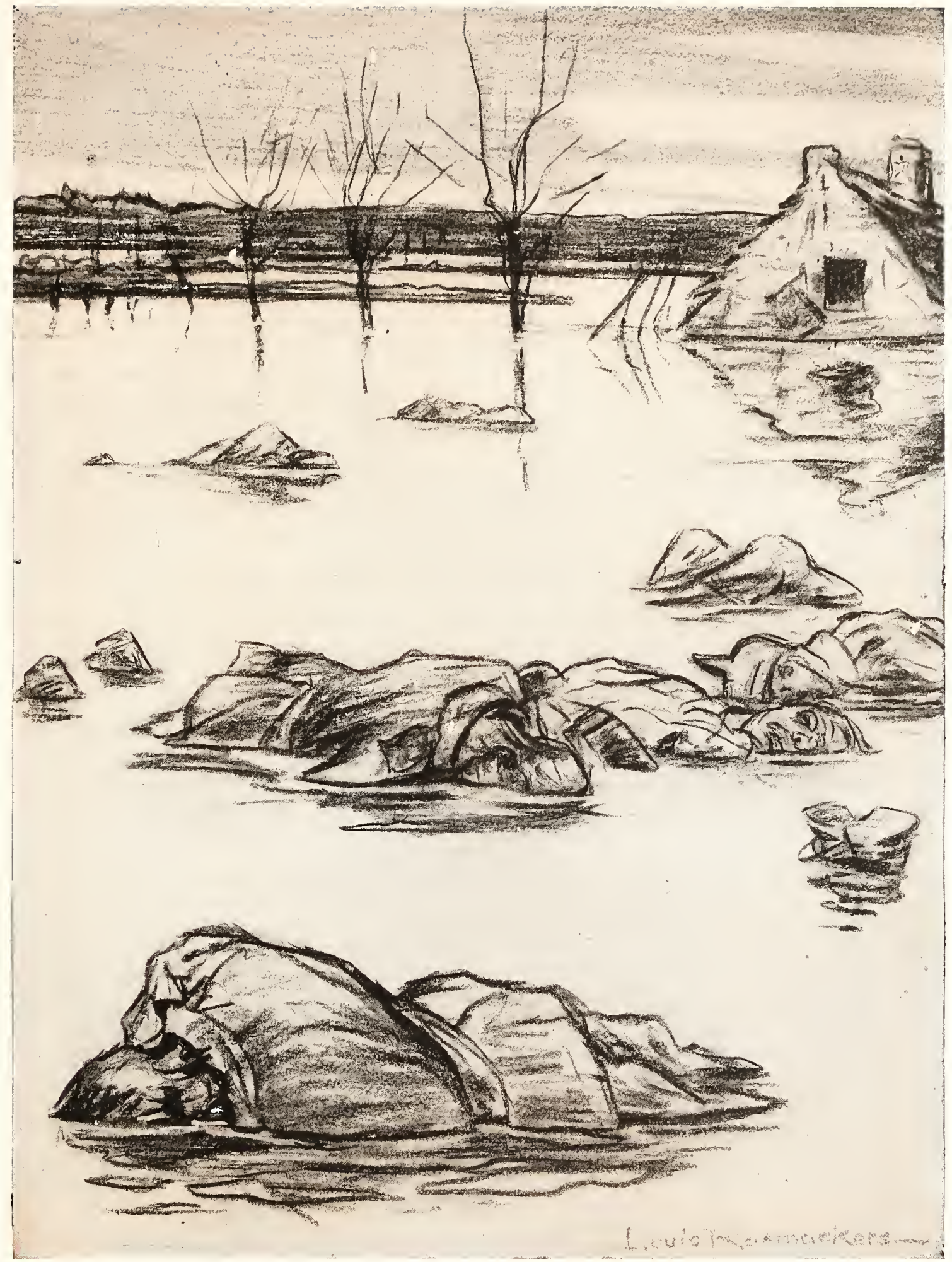

THE YSER

"We are on our way to Calais." 


\title{
Von Bethmann-Hollweg and Truth
}

\author{
"Incorrupta Fides, nudaque Veritas." \\ HORACE. \\ "Good Faith unstained, and Truth all-unadorned."
}

\begin{abstract}
7 UDA VERITAS: it was Horace who in a famous Ode first presented the figure of Truth thus. And whom did he make her companions and sisters? They were three, and their names were "Modesty," "Fair Dealing," and "Good Faith." The four sisters do indeed go together in a quadruple alliance and entente, and when one is flouted or estranged, the others are alienated and become enemies too.
\end{abstract}

The Germans were believed to be--some few still believe them to be - a "truthloving nation." They had a passion, we were told, for truth, for accuracy, for scientific exactness. Theirs might be a blunt and brutal frankness, but they were at least downright and truthful.

Well, they first flouted Modesty-they bragged and blustered, bluffed and "bounded." They could not keep it up. They had to act. Fair Dealing went by the board. Then Good Faith became impossible, for, as this very von BethmannHollweg declared, "Necessity knew no law." Now they have forsaken Truth. They must deceive their own people. The "lie" has entered into their soul. Never was so systematic a use made of falsehoods small and great.

But Truth expelled is not powerless. Naked, she is still not weaponless. She has her little "periscope," her magic mirror, which shows the liar himself, as well as the world, what he is like. And she has another weapon, as those who know their "Paradise Lost" will remember:

\footnotetext{
“Bright Ithuriel's lance

Truth kindling truth where'er it glance."
}

It is not shown here, for it is invisible, but none the less potent. With it Truth can indeed "shame the devil." She not only shows what the liar is like outside, but reveals his inner hideousness, and actual shape, for all to see.

There are many sayings about Truth, and they are all awkward for the liar. "Truth will out," said a witty English judge, "even in an affidavit." It will out, even in a German Chancellor's démenti.

The most famous is

"Magna est veritas et pravalet"

"Great is Truth and she prevails," in the end.

Yes, "She is on the path, and nothing will stop her." She started on the hills of the little but free republic of Switzerland; she is slowly traversing the plains of the vast free republic of America. Her last contest will be over the Germans themselves.

HERBERT WARREN. 


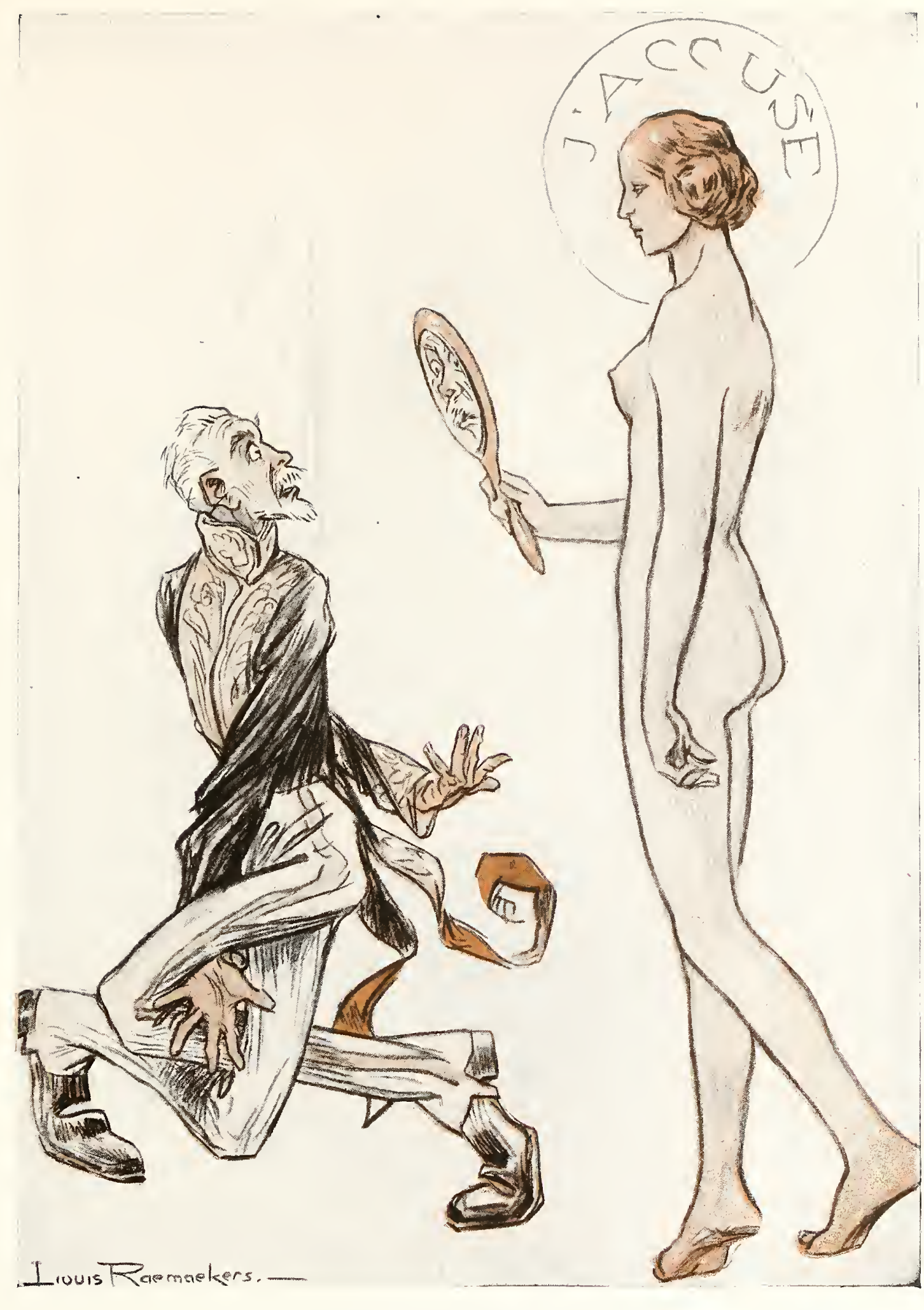

VON BETHMANN-HOLLWEG AND TRUTH

"Truth is on the path and nothing will stay her." 


\section{Van Tromp and De Ruyter}

A

GENERATION ago a little clique of wise men at Oxford patted themselves on the back for having discovered "The Historical

Method." But the common people of all countries have always known it. The names of the great dead are not forgotten, nor yet the great things for which they stood. There may be no strict liturgy for the ancestor worship of the West, but that worship is a simple fact, and it is a thing that timorous politicians would do well to remember. Here Raemaekers appeals to his countrymen to regard their past, to be worthy of the great seamen who took the Dutch fleet up the Medway, and lashed brooms to the mast-head of the ships that swept the sea clear of British enemies.

The Dutch were fighting for their liberty then. Great Britain is fighting for liberty in Europe to-day-and for Dutch liberty to boot. The enemy of all liberty uses Holland as a short cut whereby her pirates of the air can get more quickly to their murder work in England. Would the hero ancestors, of whom the Dutch so boast, have tolerated this indignity? The artist seer supplies the answer.

Note the mixture of the ghostly and the real in this vivid and vivacious drawing. But if it is easy to see through the faint outlines of the sailor spirits, it is easier for these gallant ghosts to see through the unrealities of their descendants' fears and hesitations. The anger of the heroes is plainly too great for words. How compressed the lips! How tense the attitude! The hands gripped in the angriest sort of impatience! Mark the subtle mingling of seaman and burgher in the poise and figures. Mark particularly Van Tromp's stiffened forefinger on his staff.

Is the fate of L19 the fruit of our artist's stinging reminder that Holland once had nobler spirits and braver days?

ARTHUR POLLEN. 


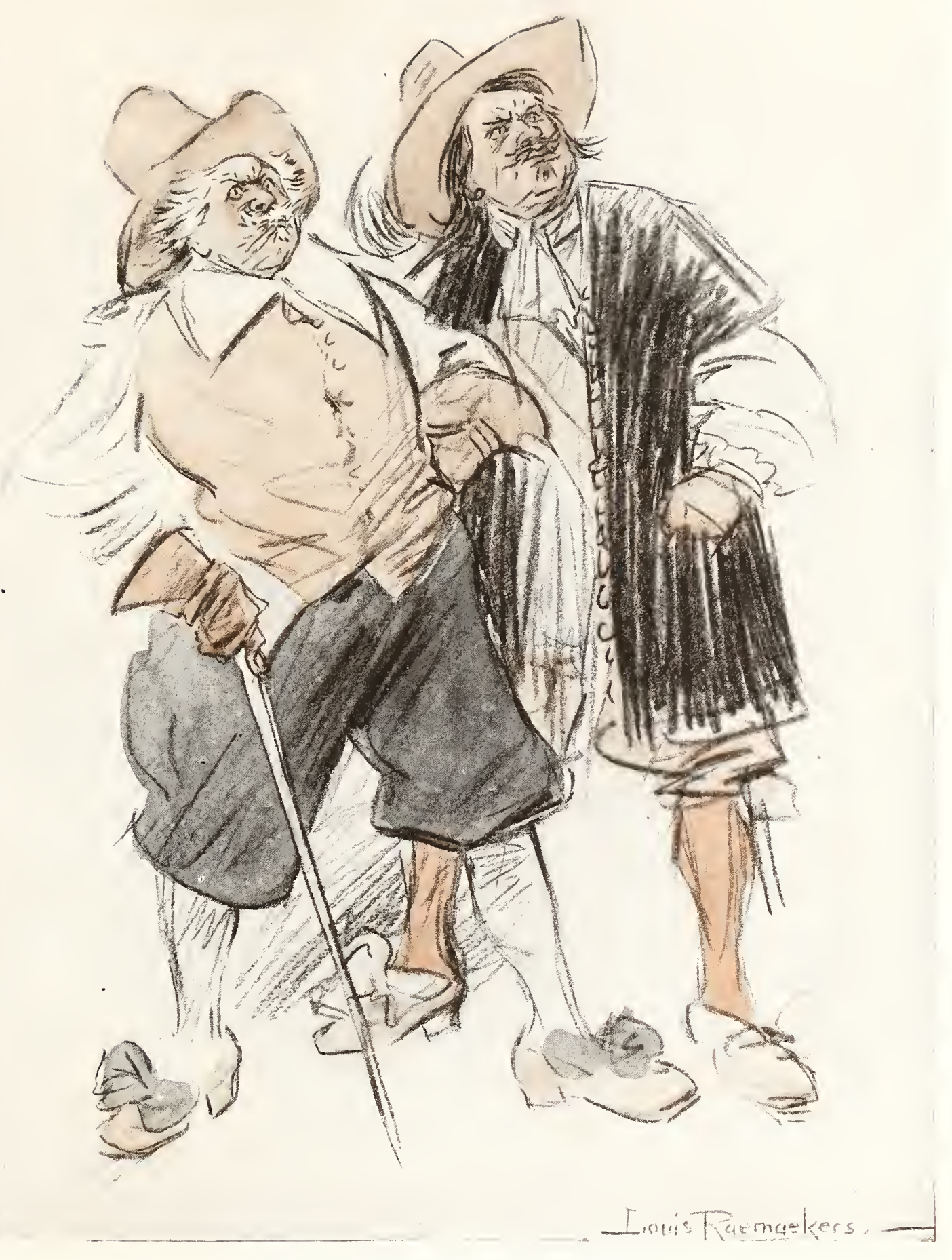

VAN TROMP AND DE RUYTER

"So long as you permit Zeppelins to cross our land you surely should cease to boast of our deeds."

Whenever a Dutchman wishes to speak of the great past of his country he calls to mind the names of these heroes. 


\section{War and Christ}

7 HE deliberate war made by Prussia in all those areas which she can reach or occupy against the symbols and sacred objects of the Christian faith is a phenomenon in every way worthy of consideration. It is clearly not a matter of accident. The bombardment at Rheims Cathedral, for example, can be proved to have been deliberate. It had no military object; and the subsequent attempts to manufacture a military reason for it only produced a version of the occurrence not only incredible but in flat contradiction to the original admissions of the Germans themselves. But such episodes as those of Rheims and Louvain merely attract the attention of the world because of the celebrity of the outraged shrines. All who are familiar with the facts know that deliberate sacrilege no less than deliberate rape and deliberate murder has everywhere marked the track of the German army.

The offence has been malignant. That does not, of course, mean that it has been irrational; quite the contrary. One fully admits that Prussia, being what she is, has every cause to hate the Cross, and every motive to vent the agonized fury of a lost soul upon things sacred to the God she hates.

The moral suggested by this cartoon of Raemaekers' must not be confused with the ridiculous and unhistoric pretence that war itself is essentially unchristian. When Mr. Bernard Shaw, if I remember right, drew from the affair of Rheims the astonishing moral that we cannot have at the same time "glorious wars and glorious cathedrals," he might surely have remembered that the age in which Rheims Cathedral was built, whatever else it was, was not an age of Pacifism. The insult to Jesus Christ is not in the sword (which in His own words He came to bring), but in the profanation of the sword. It is in cruelty, injustice, treachery, unbridled lust, the worship of unrighteous strength -in fact, in all that can be summed up in the single word "Prussia."

CECIL CHESTERTON. 


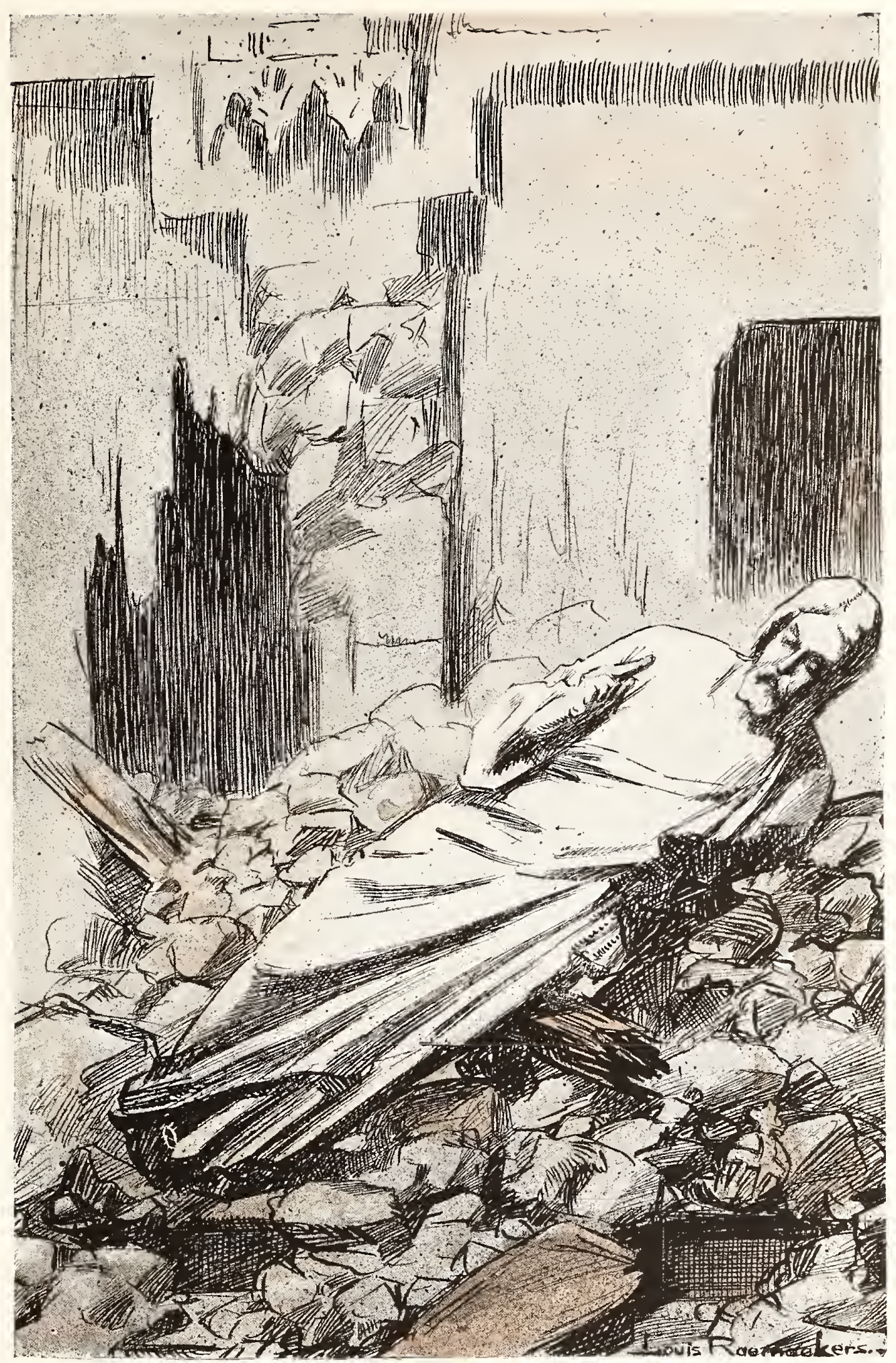

WAR AND CHRIST 


\section{Barbed Wire}

S

AVE for the spiked helmets, the gruesome figures in the foreground of this cartoon might have belonged in life to any one of the warring nationalities. It is a noteworthy fact, however, that not one of the nations at war has shown so little care for its dead as Germany, whose corpses lie and rot on every front on which they are engaged.

The world cannot blame Germany for the introduction of barbed wire as an accessory of war, though it is well known that German wire surpasses any other in sheer devilish ingenuity; not that it is more effective as an entanglement, but its barbs are longer, and are set more closely together, than in the wire used by other nationalities; it is, in short, more frightful, and thus is in keeping with the rest of the accessories of the German war machine.

But this in the cartoon is normal barbed wire, with its normal burden. One may question whether the All-Highest War Lord, who in the course of his many inspections of the various fronts must have seen sights like this, is ever troubled by the thought that these, his men, lie and hang thus for his pleasure, that their ghastly fate is a part of his glorious plan. He set out to remake the world, and here is one of the many results-broken corpses in the waste.

Part of the plan, broken corpses in the waste. By the waste and the corpses that he made shall men remember the author and framer of this greatest war.

E. CHARLES VIVIAN. 

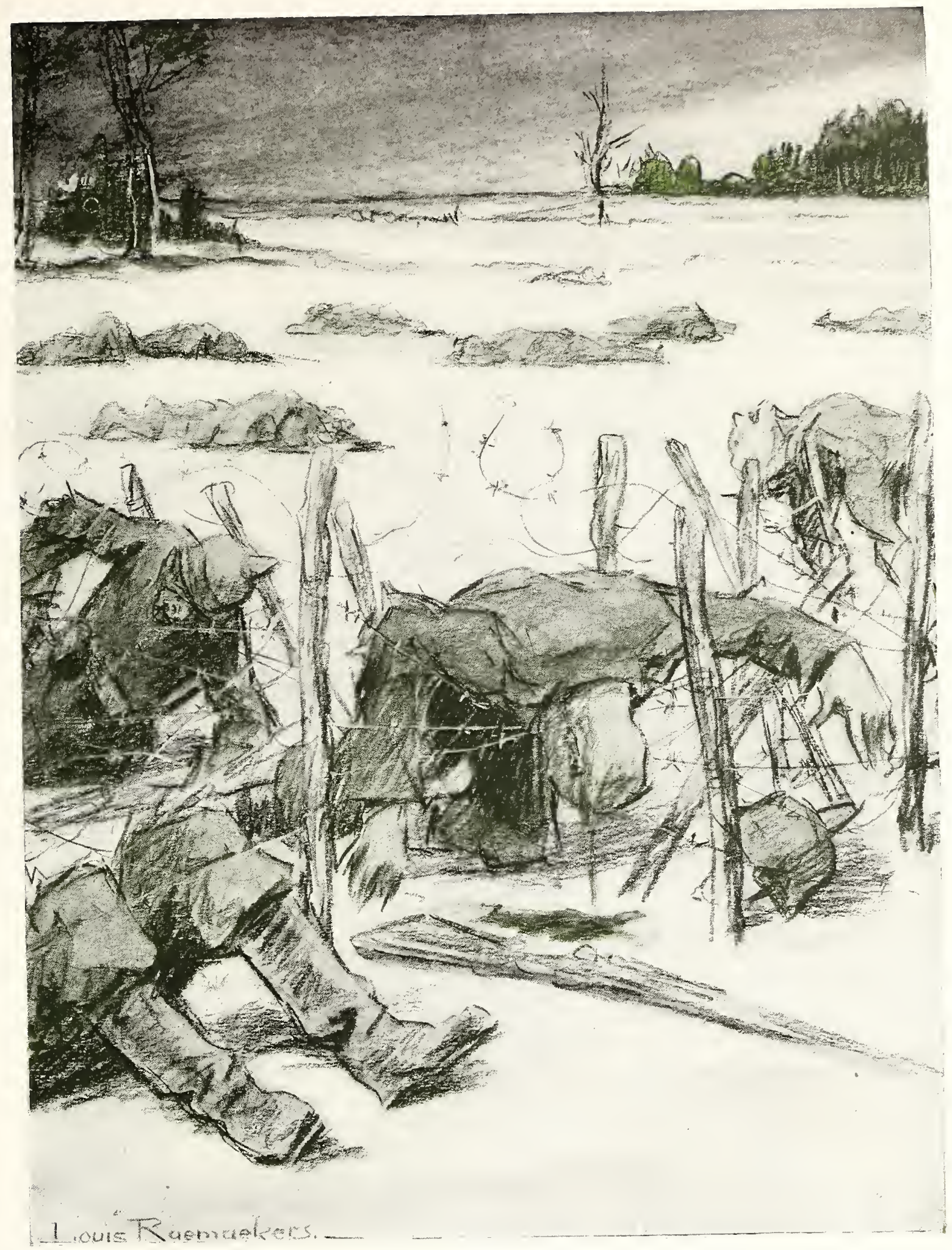

BARBED WIRE 


\section{The Higher Politics}

7 HERE is a significance in this cartoon which I believe will appeal much more strongly to the firing line than to Home. The Front distrusts politics, and especially the higher politics. That means the juggling and wire-pulling of the Chancelleries, and the Front has an uneasy conviction that at the subtleties and craftiness and cunning of the diplomatic game we cannot compete with "The Bosche." Hard knocks and straight fighting the Front does understand, and at that game are cheerfully confident of winning in the long run.

It would be bitter news to the fighting men that any peace had been patched up on any terms but those the Allies soon or late will be in a position to dictate, to lay down and say flatly, "Take them and have Peace; or leave them and go on getting licked." The Front doesn't like War. No man who has endured the horrors and savagery and "blood, mud, and misery" of civilized warfare could pretend to like it. No man who has endured the long-drawn misery of manning the waterlogged trenches for days and weeks and months can look forward with anything but apprehension to another winter of war. No man who has attacked across the inferno of the shell-and-bullet-swept "neutral ground," or has hung on with tight-clenched teeth to the battered ruins of the forward fire trench under a murderous rain of machine-gun and rifle bullets, a howling tempest of shells, an earth-shaking tornado of high explosives, can but long for the day when Peace will be declared and these horrors will be no more than a past nightmare.

But the Front will "stick it" for another winter or several winters, will go through many bitter attacks and counter-attacks to win the complete victory that will ensure, and alone will ensure, lasting peace. We know our limitations and our weaknesses. We admit that, as the American journalist bluntly put it, we are "poor starters," but we know just as surely he was right in completing the phrase, "but darn good finishers." Let the "higher politicians" on our side stand down and leave the fighting men to finish the argument. Let them keep the ring clear, and let the Front fight it out. The Front doesn't mind "taking the responsibility," and it will give "Kaiser Bill" and "Little Willie" all the responsibilities they can handle before the Great Game is over.

BOYD CABLE. 


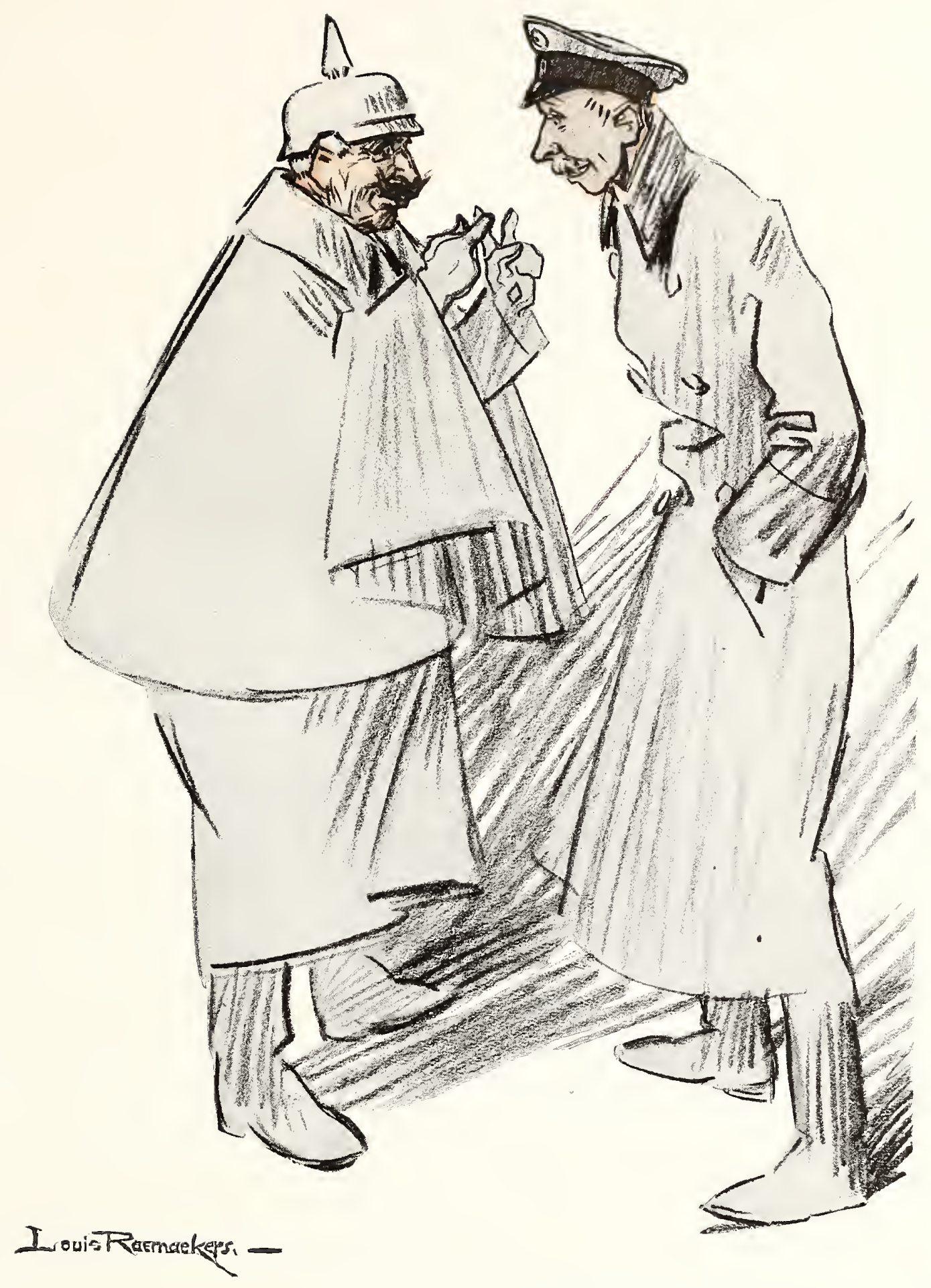

THE HIGHER POLITICS

THE KAISER: "We will propose peace terms; if they accept them, we are the gainers; if they refuse them, the responsibility will rest with them." 


\section{The Loan Game}

$\mathrm{R}$

AEMAEKERS is pitiless, but never oversteps the truth. $\mathrm{Na}$ tional Debts are ever national millstones, worn around the neck. They are worn unwillingly, and they are not ornamental; they are a burden, and the weight is sometimes crushing. A prospect of that sort seems to be the lot of several of the "Great Powers" of Europe for the remainder, and the greater portion, of the Twentieth Century. Though German "civilization" were more worthy of such a term and its associations as Kultur ten times over, would it become any Potentate and his advisers to impose it on so many countries at such a cost in suffering as all this-and more?

But Kaiser Wilhelm and his crew of State-at-any-price men impose not on other peoples only; they impose on their own kith and kin. Look at these three sad and apprehensive figures playing the Loan Game - the first, the second, the third Loan! Children, says the artist, passing the coin from one hand to another's, and getting richer at each pass!! Yes, children, the German people treated so by a few dominies. State dominies and the Director (or dupe!) at Berlin! No people gains, every people loses by incurring a Debt; but in Germany, and to-day! to incur an indebtedness, contract a loss, does not suffice; the people must not know it.

Even the children know that coin has not left them richer: many, very many Germans know the Kultur War to be ruinous: but Berlin must play the Game still, and assume that the tricks and aims cannot be understood! It is lack of regard for other nations carried into German Finance; and all because the bureaucratic military heart is a stone. The piling up of State paper goes on, but not merrily, as Michael goes from Darlehnkasse to Reichsbank, one, two, three (and is about to go the fourth time!). This game of processions to the Kasse does not increase the available wealth within beleaguered Germany: and the 100-mark Note has no reference to material wealth securing it.

Now, the Commercial magnates of Gernany realize the crushing fact-No indemnity possible!! and what of the Notes which are held? When shades of night fall heavily, and the Loan Game can be played no more, will the German people, tricked and impoverished, go to bed supperless and silent? German finance IS "a scrap of paper."

W. M. J. WILLIAMS. 


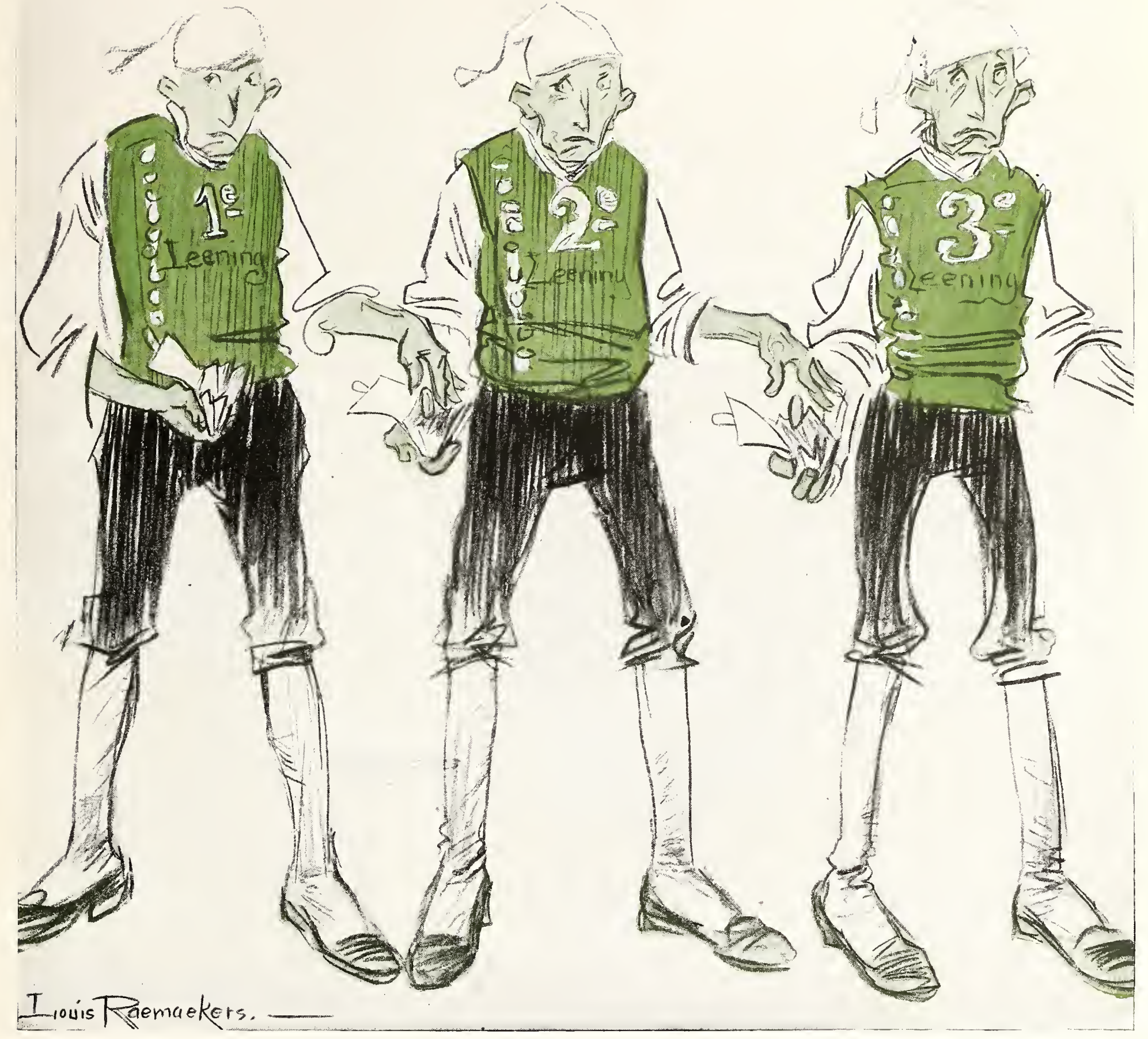

WE DON'T UNDERSTAND THIS LOAN GAME

In Germany there is a game by which children passing a coin from one to another are supposed to, but do not, get richer. 


\section{A War of Rapine}

$\mathrm{T}$

RUE, O Liebknecht, it is indeed a war of rapine, engendered, planned, and brought about by the nation to which you belong.

Yet, foul as is that nation, its foulness is not greater than your futility, by which you show up the strength of that which you oppose with as much effect as our own Snowden and Casement can claim for their efforts to arrest the work of the Allies.

Men who claim British birth claim also the quality of loyalty, as a rule, and thus there can be little sympathy with such a one as this Liebknecht, whom Raemaekers shows as a little ascetic in the presence of the sombre War Lord. It is part of the plan of Nature that every country shall breed men like this: men who are constitutionally opposed to the current of affairs, ridiculously futile, blatantly noisy, the type of which extreme Socialists and Syndicalists are made. Possessed of a certain obstinacy which is almost akin to courage, they accomplish nothing, save to remain in the public eye.

Such is Liebknecht, apostle of a creed that would save the world by the gospel of mediocrity, were human nature other than it is. But, in considering this Liebknecht, let us not forget that he has no more love for England, or for any of the Allies, than the giant whom he attempts so vainly to oppose: he is an apostle, not of peace, but of mere obstruction, perhaps well-meaning in his way, but as futile as the Crown Prince, and as ludicrous.

E. CHARLES VIVIAN. 


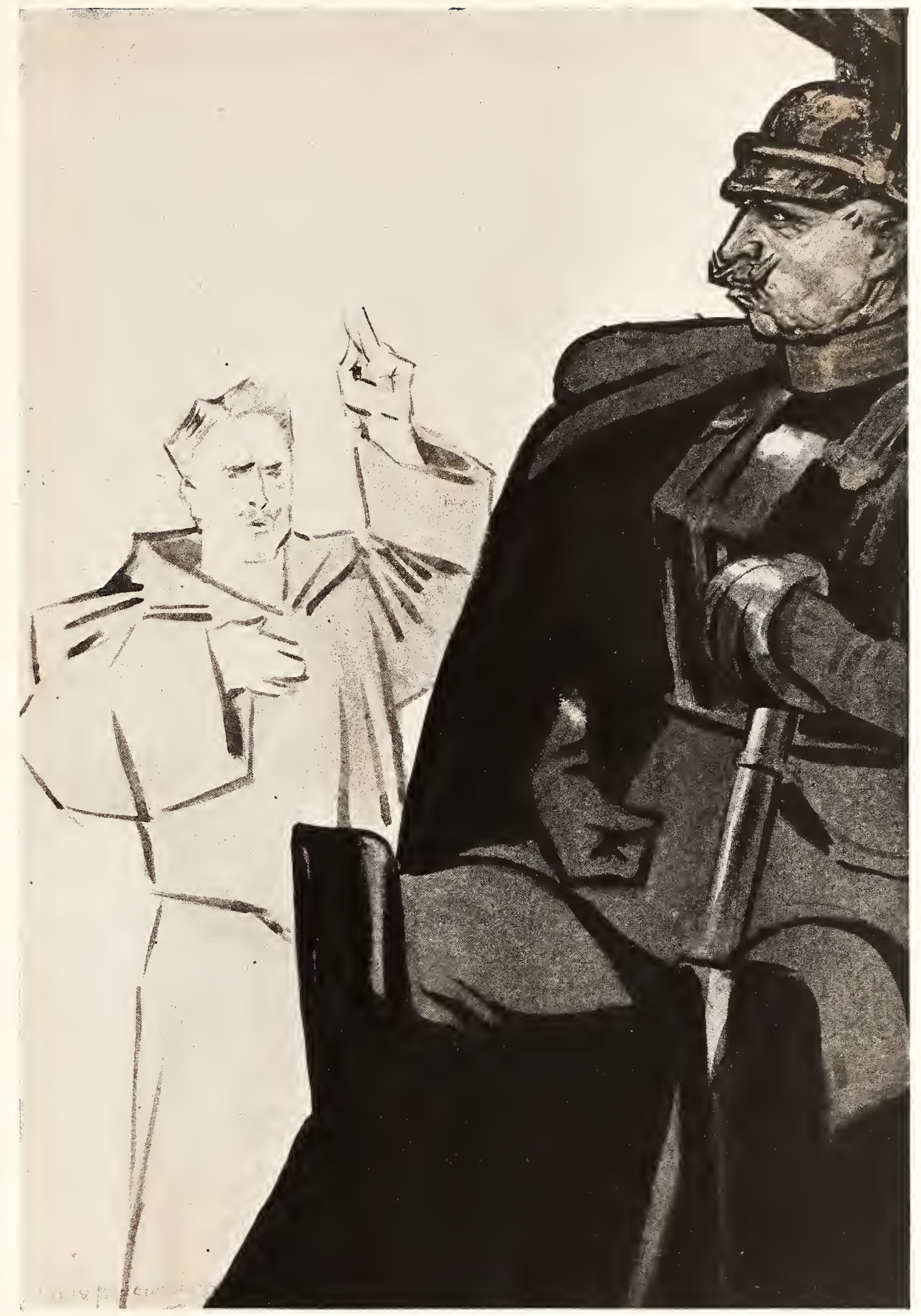

LUTHER-LIEBKNECHT IN THE REICHSTAG

"It is a war of rapine! On that I take my stand. I cannot do otherwise." Liebknecht was the one member who protested against the war. 


\section{The Dutch Junkers}

$\mathrm{S}$ OME of these drawings remind us that the great cartoonist's message was primarily delivered to his own countrymen. They explain why he was accused, but not convicted, of endangering the neutrality of the Netherlands. He presents the German monster as a menace to all freedom, and not least to the freedom of the Dutch people. Germany's allies have sold theirs; they are harnessed to the Prussian war chariot, and must drag it whither the driver bids them, whip in hand. The nations in arms against Germany are fighting for their own and each other's freedom; and the neutrals stand looking anxiously on. Raemaekers warns them that their freedom too is at stake. He sees that it will disappear if the Allies fail in the struggle, and he shows his countrymen what they may expect.

In every country there are some ignoble souls who would rather embrace servitude than fight for freedom. They have a conscientious objection to-danger. How far the Dutch Junkers deserve Raemaekers' satire it is not for foreigners to judge. But we know the type he depicts - the sporting "nuts," with their careful get-up, effeminate paraphernalia, and vacuous countenances. So long as they can wear a sporting costume and carry a gun they are prepared to take a menial place under a Prussian over-lord and submit with a feeble fatalism to the loss of national independence. It is light satire in keeping with the subject, and it provides a relief to the sombre tragedy which is the artist's prevailing mood.

A. SHADWELL. 


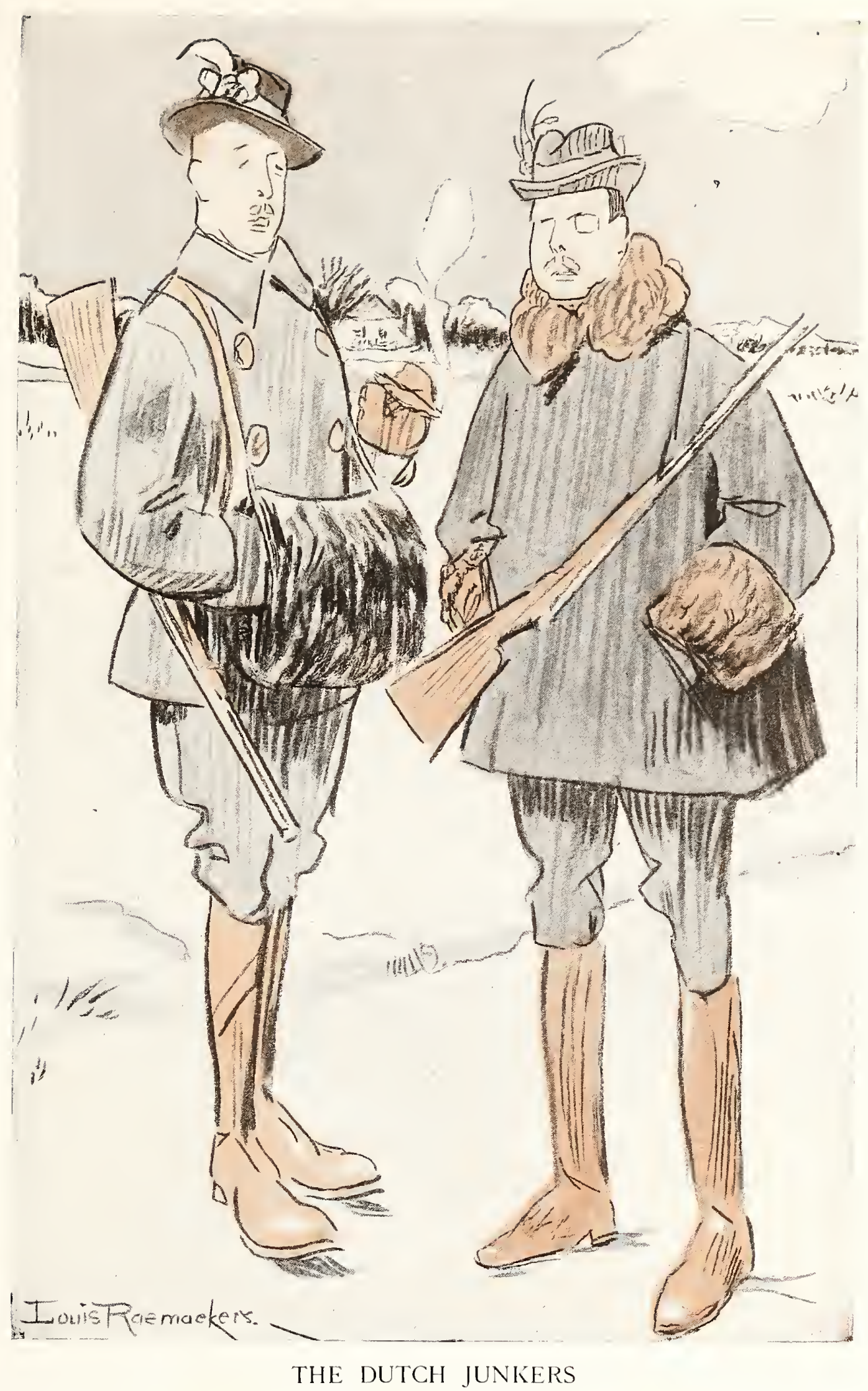

"At least we shall get posts as gamekeepers when Germany takes us after the war." 


\section{The War Makers}

THO are the Makers of Wars?

The Kings of the Earth.

And who are these Kings of the Earth?

Only men-not always even men of worth,

But claiming rule by right of birth.

And Wisdom?-does that come by birth?

Nay then-too often the reverse.

Wise father oft has son perverse,

Solomon's son was Israel's curse.

Why suffer things to reason so averse?

It always has been so,

And only now does knowledge grow

To that high point where all men know-

Who would be free must strike the blow.

And how long will man suffer so?

Until his soul of Freedom sings,

And, strengthened by his sufferings,

He breaks the worn-out leading-strings,

And calls to stricter reckonings

Those costliest things-unworthy Kings.

Here you have them!- Pilloried for all time!

And what a crew! These pitiful self-seckers and their dupes!

Not the least amazing phenomenon of these most amazing times is the fact that millions of men should consent to be hurled to certain death, and to permit the ruin of their countries, to satisfy the insensate ambitions of rulers, who, when all is said and done, are but men, and in some cases even of alien birth and personally not specially beloved by them.

Surely one outcome of this world-war will be the birth of a new determination in every nation that its own voice and its own will shall control its own destinies - that no one man or self-appointed clique shall swing it to ruin for his or their own selfish purposes. Who pays the piper must in future call the tune.

"The world has suffered much too long.

$\mathrm{O}$ wonder of the ages-

O marvel of all time-

This wonderful great patience of the peoples!

How long, O Lord, how long?"

The answer cannot come too soon for the good of the world.

JOHN OXENHAM. 


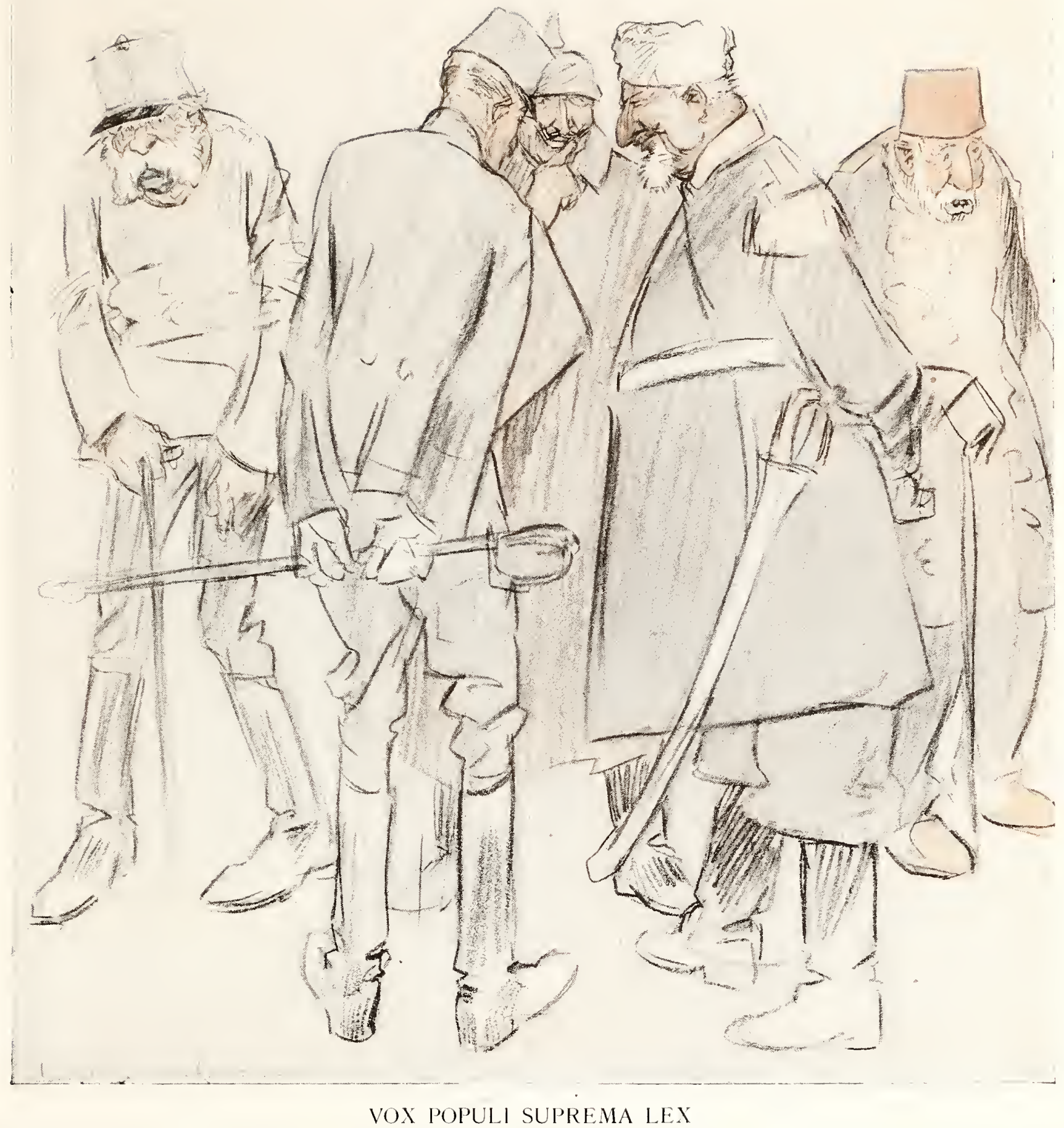

The Kaiser: "Don't bother about your people, Tino. People only have to applaud what we say." 


\section{The Christmas of Kultur, A.D. 1915}

$\mathrm{M}$

ARY, worn with grief and fear, covers her emaciated face with scarred hands, as she kneels in prayer before the infant Jesus. Joseph, grown old and feeble, nails up a barricade of planks to strengthen the door against the missiles of Kultur already bursting through it and threatening the sleeping child. So in that first Christmas, nineteen centuries ago, he saved Mary's child from the babymassacre ordered by Herod to preserve his own throne.

Kultur, the gathered wisdom of the ages, has brought us back to the same Holy War. What a Christmas! What a Festival of Peace and goodwill towards men!

People ask: Why does God allow it? Is God dead? Foolish questions. When I was at school I had the good fortune to be under a great teacher whose name is honoured to-day. He used to tell us that the most terrible verse in the Bible was: "So He gave them up unto their own hearts' lust and they walked in their own counsels" (Ps. lxxxi, 13).

Man has the knowledge of good and evil; he has eaten of the tree and insists on going his own way. He knows best. Is not this the age of science and Kultur? We must not cry out if the road we have chosen leads to disaster.

Yet still the Child of Christmas lives and a divine light shines round His head. He sleeps.

A. SHADWELL. 


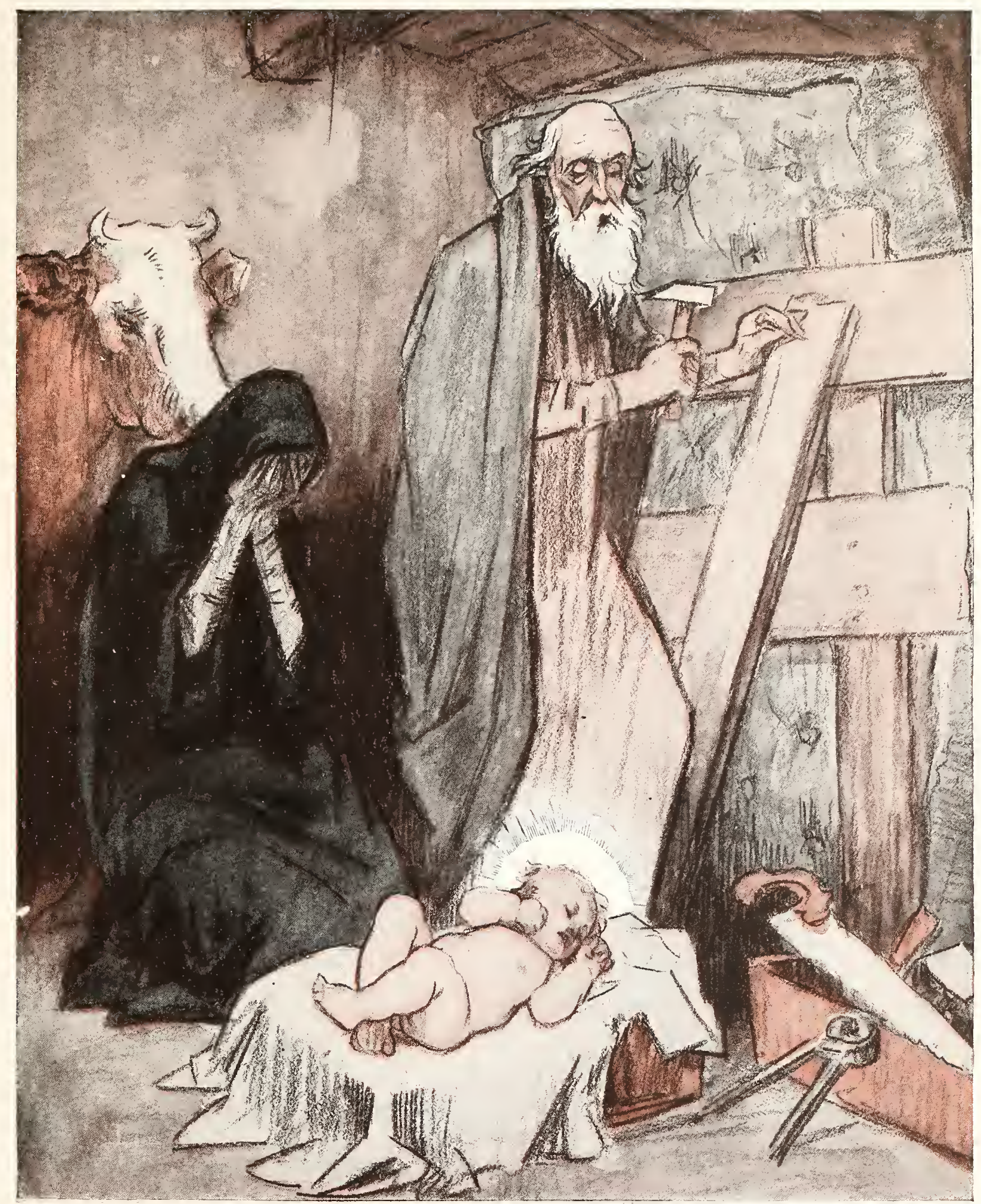

CHRISTMAS EVE

Joseph: "The Holy War is at the door!" 


\section{Serbia}

G ENIUS has set forth the most brutal characteristic of the Hun. In moments of triumph, invariably he is the bully, and, as invariably, he wallows in brutality - witness Belgium under his iron heel and, in this cartoon, stricken Serbia impotent to ward off the blow about to be dealt by a monstrous fist. That is the Teuton conception of War, Merry War (Lustige Krieg)! In the English prize-ring we have an axiom indelibly impressed upon novices- "Follow up one stout blow with another-quick!" That, also, is the consummate art of war. But when a man is knocked out we don't savage him as he lies senseless at our feet. The Hun does. His axiom is - "As you are strong, be merciless!"

In the small pig-eyes, in the gross, sensual lips, the mandril-like jaw, the misshapen ear, I see not merely a lifelike portrait of a Hun but a composite photograph of all Huns, something which should hang in every house in the kingdom until the terms of such a peace have been imposed which will make the shambles in Belgium, Poland, and Serbia an eternal nightmare of the past, never to be repeated in the future. And over the anæmic hearts of the Trevelyans, the Ramsay MacDonalds, the Arthur Ponsonbys, who dare to prattle of a peace that shall not humiliate Germany, I would have this cartoon tattooed, not in indigo, but in vermilion.

If Ulysses Grant exacted from the gallant Robert Lee "Unconditional Surrender," and if our generation approves-as it does-that grim ultimatum, what will be the verdict of posterity shouid we as a nation - we who have been spared the unspeakable horrors under which other less isolated countries have been "bled white"-descend to the infamy of a compromise between the Powers of Darkness and Light? The Huns respect Force, and nothing else. Mercy provokes contempt and laughter. I hold no brief for reprisals upon helpless women and children; I am not an advocate of what is called the "commercial extermination of Germany"; but it is my sincerest conviction that criminals must be punished. The Most Highest War Lord and his people, not excluding the little children who held high holiday when the Lusilania was torpedoed, are-CRIMINAL.S.

HORACE ANNESLEY VACHELL. 


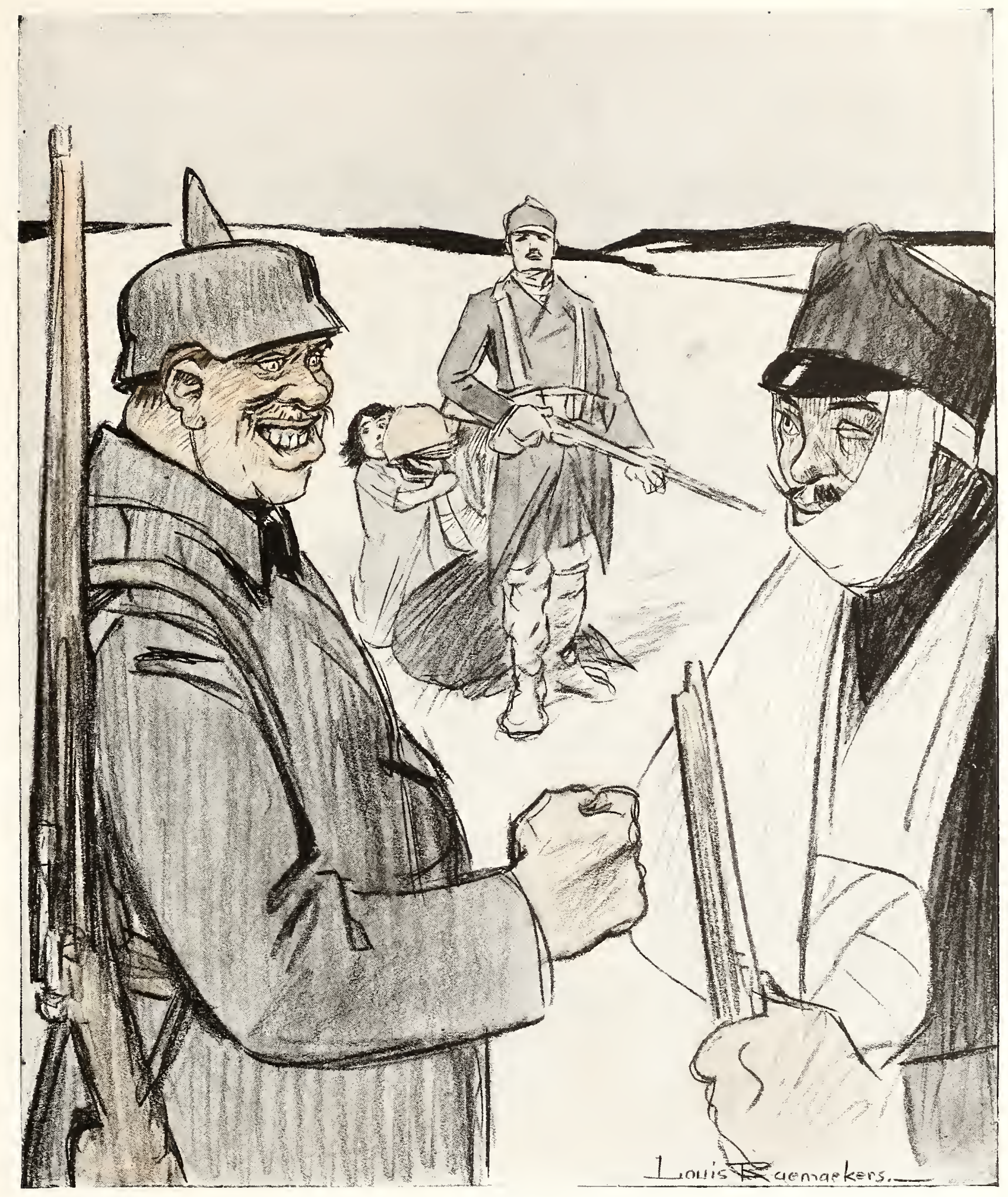

SERBIA 


\section{The Last of the Race}

$\mathrm{R}$ AEMAEKERS, the master of an infinite variety of moods and touch, reserves a special category of scorn for Von Tirpilz. Savage cruelty in war, the wanton destruction of life and property, the whole gospel of frightfulness-these things have been abandoned (so the historians tell us), not because savagery was bad morals, but because it was the worst way of making war. It was wiser to take the enemy's property and put it to your own use than to destroy it. If it was plundered it was wasted. It was wiser to spare men, women, and children, so that they should be better subjects if they remained conquered, less irreconcilable enemies, if they were restored to their old allegiance. Besides, murder, plunder, and rapine demoralized your men. They made them less efficient troops for fighting. Doubtless the argument is sound. But it would never have been accepted had not the horrors of savagery been utterly loathsome and repulsive to the nations that abandoned them.

Conventions in the direction of humanity are not, then, artificial restrictions in the use of force. They are natural restrictions, because all Christian and civilized people would far rather observe them than not. Germany has revelled in abandoning every restraint. Raemaekers shows the cruelty, the wickedness of this in scores of his drawings. Here it is its folly that he emphasizes.

The submarine is no longer a death-dealing terror. It has become a blubbering fish. And the author of its crimes is no diabolical triton, but a semi-imbecile old dotard, round whom his evil-but terrifiedbrood have clustered; they fawning on him in terror, he fondling them in shaky, decrepit fondness. Note the flaccid paunch, the withered top, and the foolish, hysterical face. How the full-dress cocked hat shames his nakedness!

And this, remember, is the German High Admiral as history will know him, when the futility of his crimes is proved, their evil put out of memory, and only their foolishness remains!

ARTHUR POLLEN. 


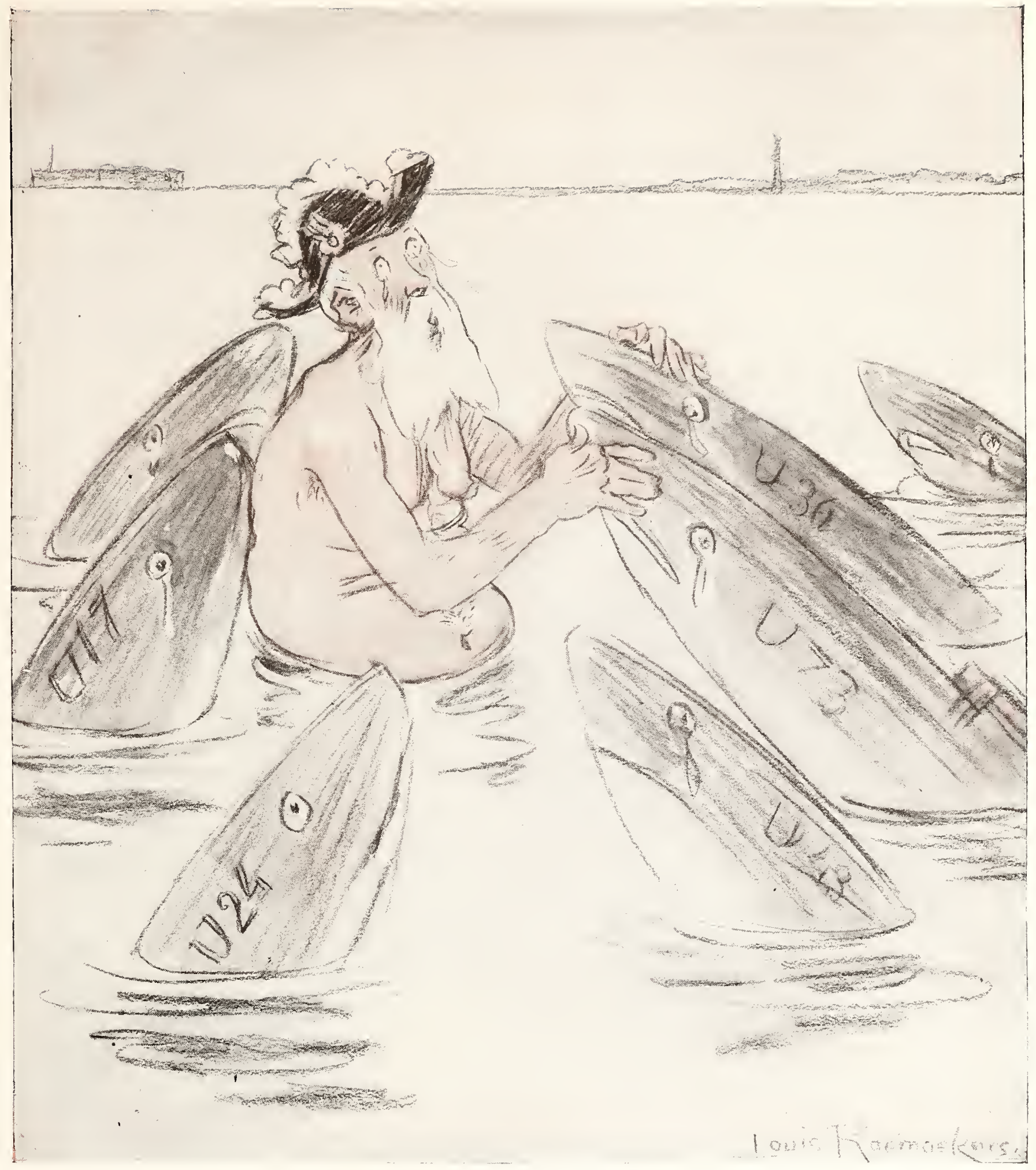

THE LAST OF THE RACE

Von Tirpitz: No, my dears, l'm not sending any more of you to those wicked English; the survivors shall go to the Zoo." 


\section{The Curriculum}

HE nations are being educated amain, let us hope. Germany has prided herself on her education, her learning, and on her 1 Kultur. To-day she is beyond the calculation of all that foresight which has been her boast, and foible. Human nature, other than German, has not been on the national curriculum, and, as in other departments of study, what has not been reduced to rule and line is beyond the ken and apprehension. How stupendously wrong a Power which could count, and into a European War! on insurrection in India, the Cape, and other parts of the British Empire! and how naïvely did Herr von Bethmann-Hollweg disclose the Zeitgeist of German rulers when with passion he declared Britain to be going to war for "a scrap of paper!" A purpose to serve, a treaty becomes "a scrap"-in German courtly hands.

The artist depicts a scene, with masterly pencil, where Von Bethmann-Hollweg himself is charged by the All-Highest to be schoolmaster. It is a grim department of the training. Think of the unseen as well as that shown. What you do see is the lordly, truculent Kaiser, raising that menacing finger again. In spacious chair, he sits defiant, aggressive, as a ferocious captain; and there opposite is the "great Chancellor." bent, submissive, apprehensive, tablet and pencil ready to take down the very word of Kaiserly wisdom and will. What is it? The day's fare for a week! reaching a climax of "No dinner" on Saturday, and "Hate" on Sunday! Educative! of course it will be.

Some day, not so far, even the German people will not regard the orders of the Army and Navy Staff, the cruel mercies of the Junkers, as a revelation of Heaven's will. Three pounds of sugar for a family's monthly supply will educate, even when the gospel of force has been preached for fifty years to a docile people. Many of us are in "a strait betwixt two" as we see how thousands of inoffensive old men, women, and children are made to suffer, are placed by the All-Highest in this Copper and Hate School. It is not this, that, and the other that causes this, but the Director of the School, who does not, while the miserable scholars do, know what it is to endure "No dinner," not only on Saturdays, but many other days. And all to gratify the mad projectors imposing Kultur on an unwilling world!

W. M. J. WILLIAMS. 


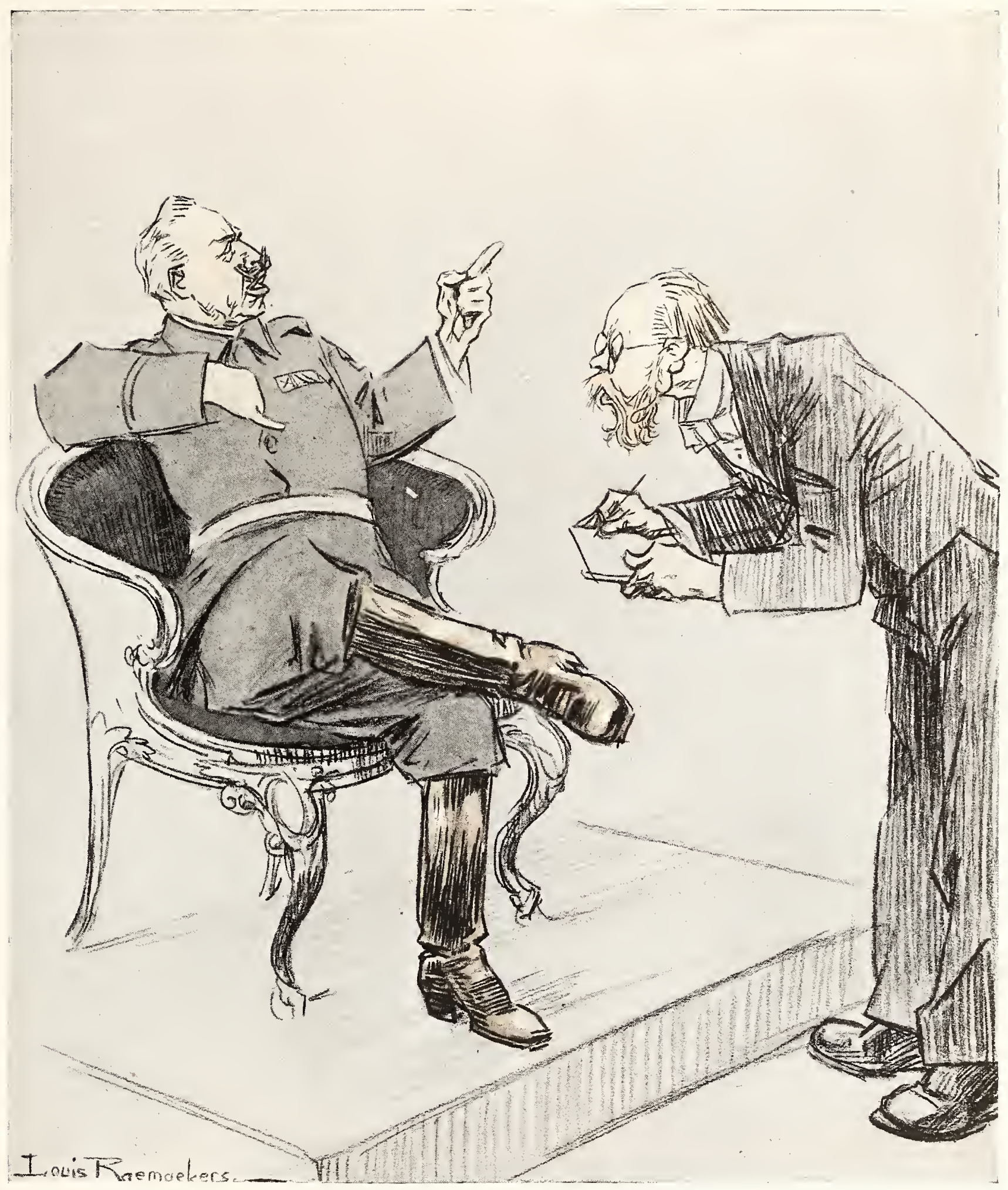

THE NEW SCHOOL CURRICULUM

William: "Write it down, schoolmaster-Monday shall be Copper Day; Tuesday, Potato Day; Wednesday, Leather Day; Thursday, Gold Day; Friday, Rubber Day; Saturday, No Dinner Day; and Sunday, Hate Day!" 


\section{The Dutch Journalist to His Belgian Confrère}

$\mathrm{W}^{\prime}$

HETHER the type here taken is a true criticism of a commercial attitude in a neutral State like Itolland, it does not become us to discuss. Raemaekers is a Dutchman, and doubtless a patriolic Dutchman. And the patriot, and the patriot alone, has not only the right but the duty of criticising his own country.

For us it is better to regard the figure as an international, and often anti-national, character who exists in all nations, and who, even in a belligerent country like our own, can often contrive to be neutral and worse than neutral. A prosperous bully with the white waistcoat and coarse, heavily cuffed hands, with which such prosperity very frequently clothes itself, is represented as thrusting food in the starved face of an evicted Belgian and saying: "Eat and hold your tongue."

The situation is worthy of such record, if only because it emphasizes an element in the general German plot against the world which is often forgotten in phrases about fire and sword. The Prussianized person is not only a military tyrant; he is equally and more often a mercantile tyrant. And what is in this respect true of the German is as true or truer of the Pro-German.

The cosmopolitan agent of Prussia is a commercial agent, and works by those modern methods of bribing and sacking, of boycott and blackmail, which are not only meaner, but often more cruel, than militarism. For any one who realizes the power of such international combinations, there is the more credit due to the artists and men of letters who, like Raemaekers himself, have decisively chosen their sicie while the issue was very doubtful. And among the Belgian confrères there must certainly have been many who showed as much courage as any soldier, when they decided not to eat and be silent, but to starve and to speak.

G. K. CHESTERTON. 


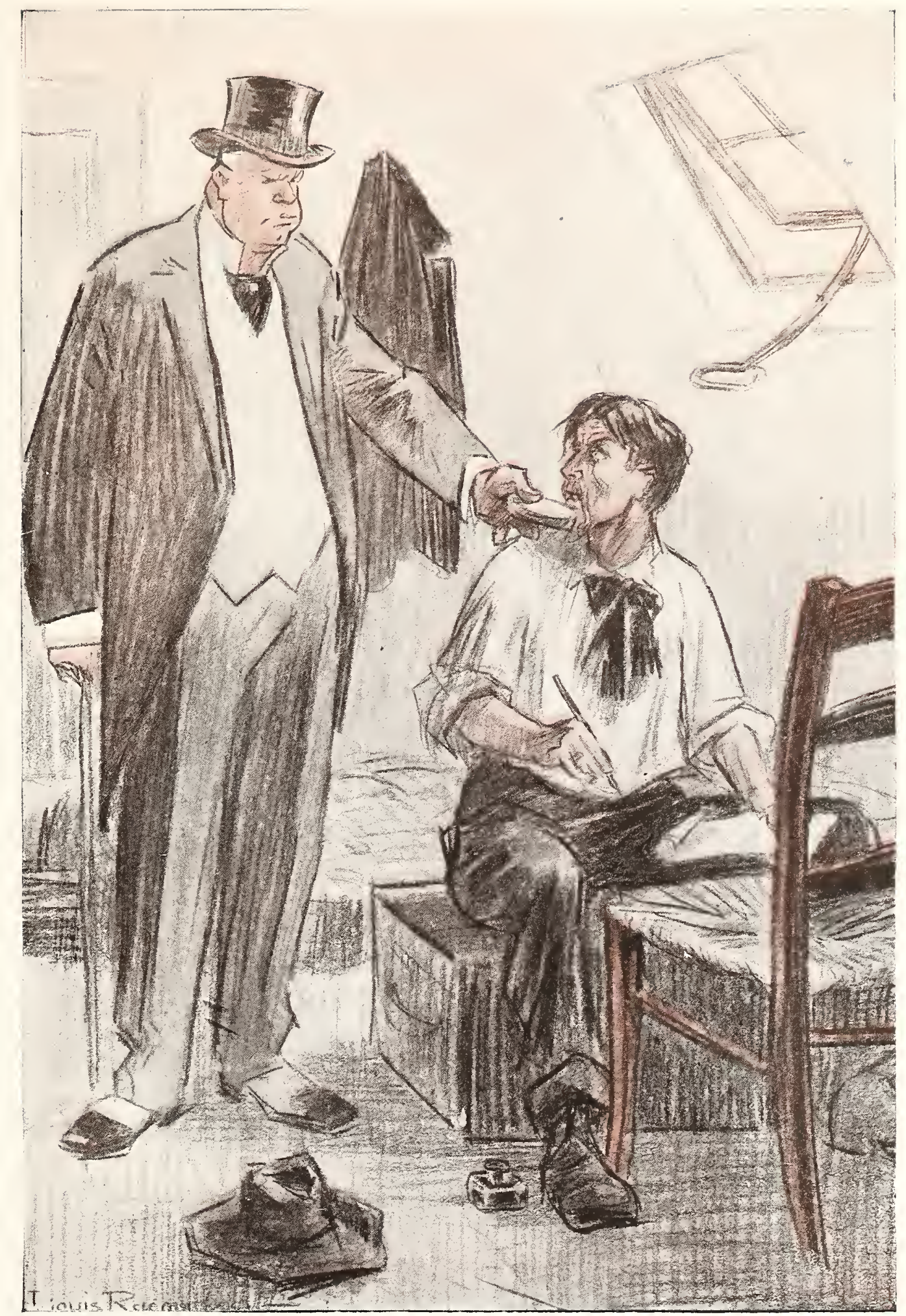

The Dutch Journalist to His Belgian Confrère: "Eat and hold your tongue." 


\section{A Bored Critic}

ROM Homeric warfare to subterranean conflict of modern trenches -1 is a far cry, and Ares, God of Battles, may well yawn at the enter1 tainment with which the Demon of War is providing him. But the spectator of this grim "revue" lacks something of the patience of its creator, and our Mephistopheles, marking the god's protest, will doubtless hurry the scene and diversify it with new devilries to restore his interest. Indeed, that has happened since Raemaekers made his picture.

The etiquette of butchery has become more complicated since Troy fell, yet it has been so far preserved till now that the fiend measures Ares with his eyes and speculates as to how far the martial god may be expected to tolerate his novel engines. Will asphyxiating gas, and destruction of non-combatants and neutrals on land and sea, trouble him? Or will he demand the rules of the game, and decline to applaud this satire on civilization, although mounted and produced regardless of cost and reckoning?

As the devil's own entertainment consists in watching the effects of his masterpiece on this warlike spectator, so it may be that those who "staged" the greatest war in mankind's history derive some bitter instruction from its reception by mankind. They know now that it is condemned by every civilized nation on earth; and before these lines are published their uncivilized catspaws will have ample reason to condemn it also. Neutrals there must be, but impartials none.

The sense and spirit of the thinking world now go so far with human reason that they demand a condition of freedom for all men and nations, be they weak or powerful. That ideal inspires the majority of human kind, and it follows that the evolution of morals sets strongly on the side of the Allies.

"War," says Bernhardi, "gives a biologically just decision, since its decisions rest on the very nature of things." So be it.

EDEN PHILLPOTTS. 


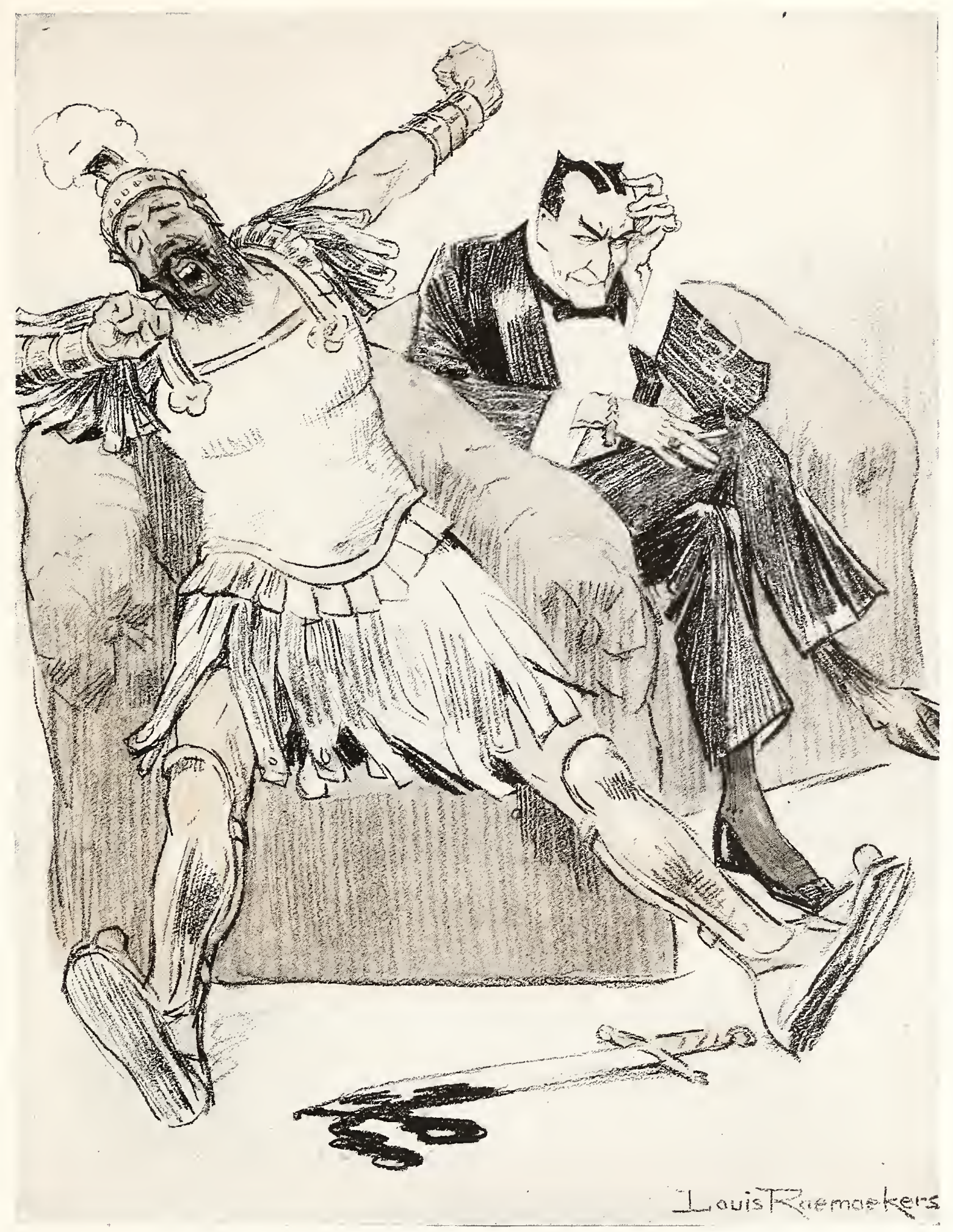

"I say, do suggest something new. This is becoming too boring." 


\section{"The Peace Woman"}

I N THIS humorous yet pathetic cartoon-humorous because of its truth to the type, and pathetic because of the futility of the effort depicted-with unfailing skill the artist shows the folly of the cry "Peace! Peace!" when there is none. In the forefront is a type of woman publicist who can never be happy unless the limelight secured by vocal effort and the advocacy of a "crazy" cause is focussed upon her. She calls "Peace!" that the world may hear, not attend. Behind her stands that other type of detached "peace woman," who has, judging from her placid yel grieved expression, apparently scarcely realized that the War is too serious and has its genesis in causes too deep-rooted to be quelled by her or her kind. One can imagine her saying: "A war! How terrible! It must be stopped."

The soldier, who is wise enough to prefer armour-plate even to a shield provided by substantially built peace women clad in white, looks on amused. The thinking world as a whole so looks on at "Arks" launched by American millionaire motor manufacturers, and at Pacifist Conferences held whilst the decision as to whether civilization or savagery shall triumph, and might be greater than right, yet hangs in the balance. There must be no thought of peace otherwise than as the ultimate reward of gallant men fighting in a just cause, and until with it can come permanent security from the "Iron Fist" of Prussian Militarism and aggression, and the precepts of Bernhardi and his kind are shown to be false. Those who talk of peace in the midst of "frightfulness," of piracy, of reckless carnage and colossal sacrifices of human life which are the fruits of an attempt to save by military glory a crapulous dynasty, however good their intention, lack both mental and moral perspective.

CLIVE HOLLAND. 


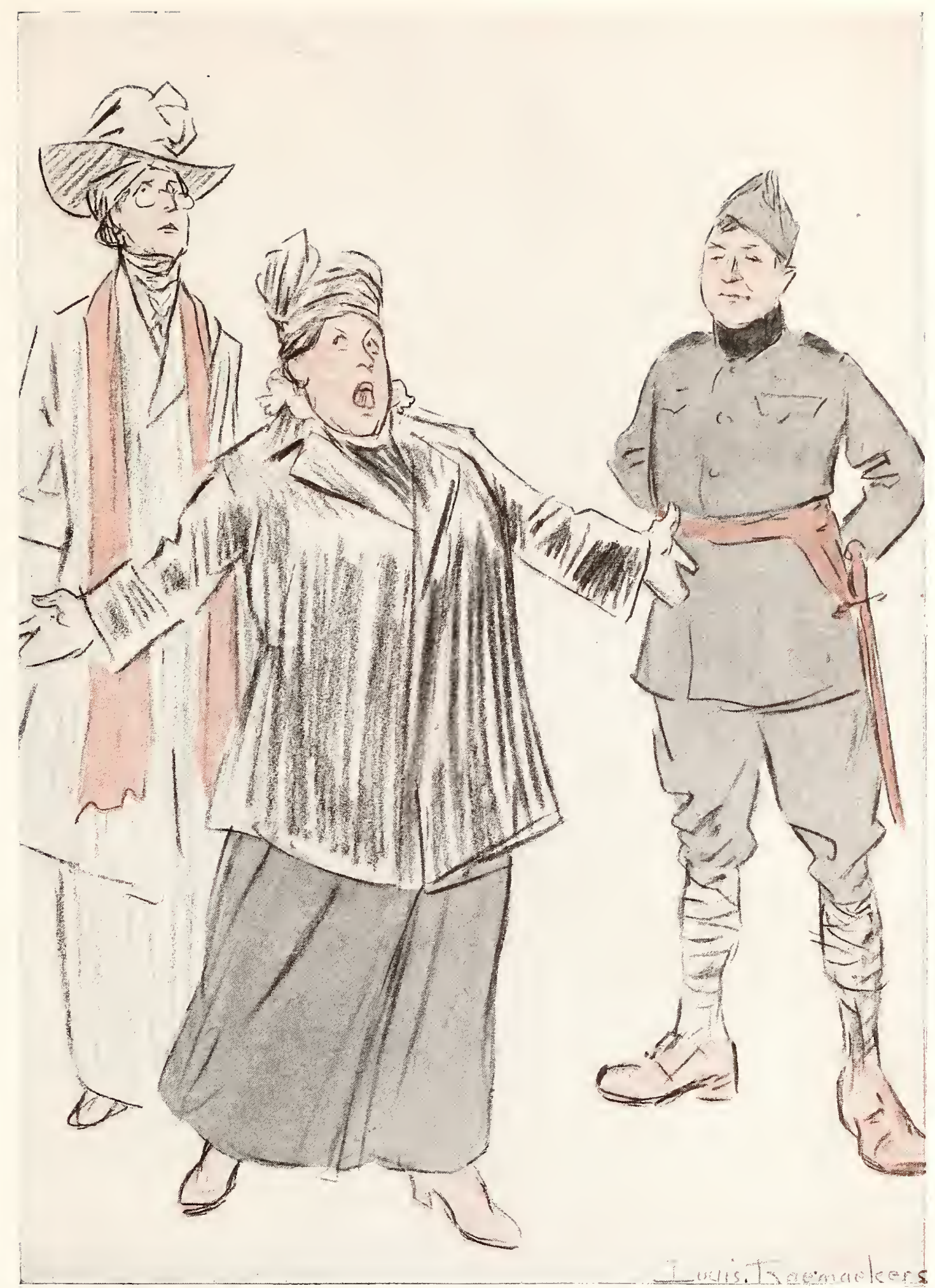

The Peace Woman: "We will march in white before our sons."

The Neutral Soldier: "Madam, we would prefer the protection of an armourplate." 


\section{The Self-satisfied Burgher}

$\mathrm{T}$

HE artist has depicted the ordinary attitude of a self-satisfied burgher not only in Holland but in other countries also. "What does it matter if we are annexed afterwards, so long as we remain neutral now?" That is the sort of speech made by selfish merchants in some of the neutral countries, especially those of Scandinavian origin. It is really a variety of the old text: "Let us eat, drink, and be merry; for to-morrow we die." Why not, it is urged, make the best of present facilities? As long as we are left alone we can pursue our ordinary industrialism. We can heap up our percentages and profits. Our trade is in a fairly flourishing condition, and we are making money. No one knows what the future may bring; why, therefore, worry about it? Besides, if the worst comes to the worst and Germany annexes us, are we quite sure that we shall be in a much worse condition than we are now? It will be to the interest of Berlin that we should carry on our usual industrial occupations. Our present liberty will probably not be interfered with, and a change of masters does not always mean ruin.

So argues the self-satisfied burgher. If life were no more than a mere matter of getting enough to eat and drink and of having a balance at the banker's, his view of the case might pass muster. But a national life depends on spiritual and ideal interests, just as a man's life "consisteth not in the abundance of the things which he possesseth." Freedom is the only principal of growth, and freedom is the one thing which German militarism desires to make impossible for all those whom she gathers into her fold. The loss of liberty means the ruin of all those ends for which a State exists. Even the material prosperity which the self-satisfied burgher desires will be definitely sacrificed by a submission to Teutonic autocracy.

W. L. COURTNEY. 


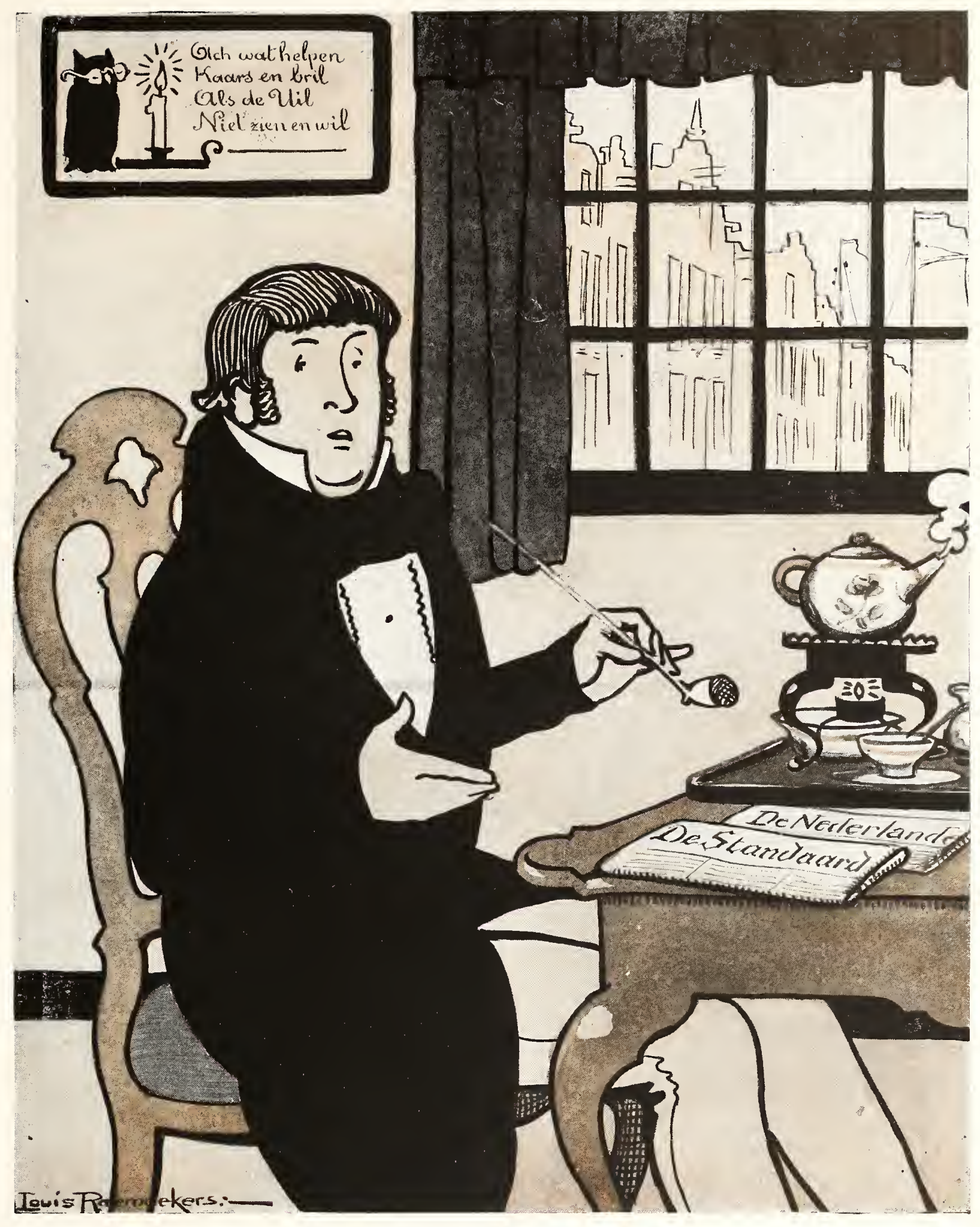

THE SELF-SATISFIED BURGHER

"What does it matter if we're annexed afterwards, so long as we remain neutral now ?" 


\section{The Decadent}

W $\mathrm{AR}$ is a fiery winnower of incapacilies. Many reputations have gone to the scrap-heap since August, 1914. None more surely than that of the braggart Crown Prince. It is said that this terrible catastrophe was largely of his bringing about and his great desire and hope.

Well - he has gol his desire, and more than he expected.

He was going to do mighty things - to smash through the frontier and lead the German hordes triumphantly through France. And what has he done?

In the treacherous surprise of the moment he got across the frontier, and there the weighty French fist met the Imperial optic, and has since developed many stars in it. He has been held, wasting men, time, opportunity, and his own little apology for a soul. He has done nething to justify his position or even his existence. He has wrecked his home-life by wanton indulgence. He has made himself notorious by his private lootings of the châteaux cursed with his presence.

Even in 1870 the native cupidity of the far finer breed of conquerors could not resist the spoils of war, and, to their eternal disgrace, trainloads of loot were sent away to decorate German homes - as burglars' wives might wear the jewellery acquired by their adventurous menfolk in the course of their nefarious operations.

But we never heard of "Unser Fritz," the then Crown Prince, ransacking the mansions he stayed in. He was a great man and a good-the very last German gentleman. And this decadent is his grandson!

"Unser Fritz" was a very noble-looking man. His grandson-oh, well, look at him and judge for yourselves! Of a surety the sight is calculated to heighten one's amazement that any nation under the sun, or craving it, could find in such a personality, even as representative of a once greal but now exploding idea, anything whatever even to put up with, much less to worship and die for.

The race of Hohenzollern has wilted and ravelled out to this. The whole world, outside Prussia, devoutly hopes ere long to have seen the last of it.

It has been at all times, with the single exception above noted, a hustling, grabbing, self-seeking race. May the eyes of Germany soon be opened! Then, surely, it will be thrust back into the obscurity whence heaven can only have permitted it to escape for the flagellation of a world which was losing its ideals and needed bracing back with a sharp, stern twist.

JOHN OXENHAM. 


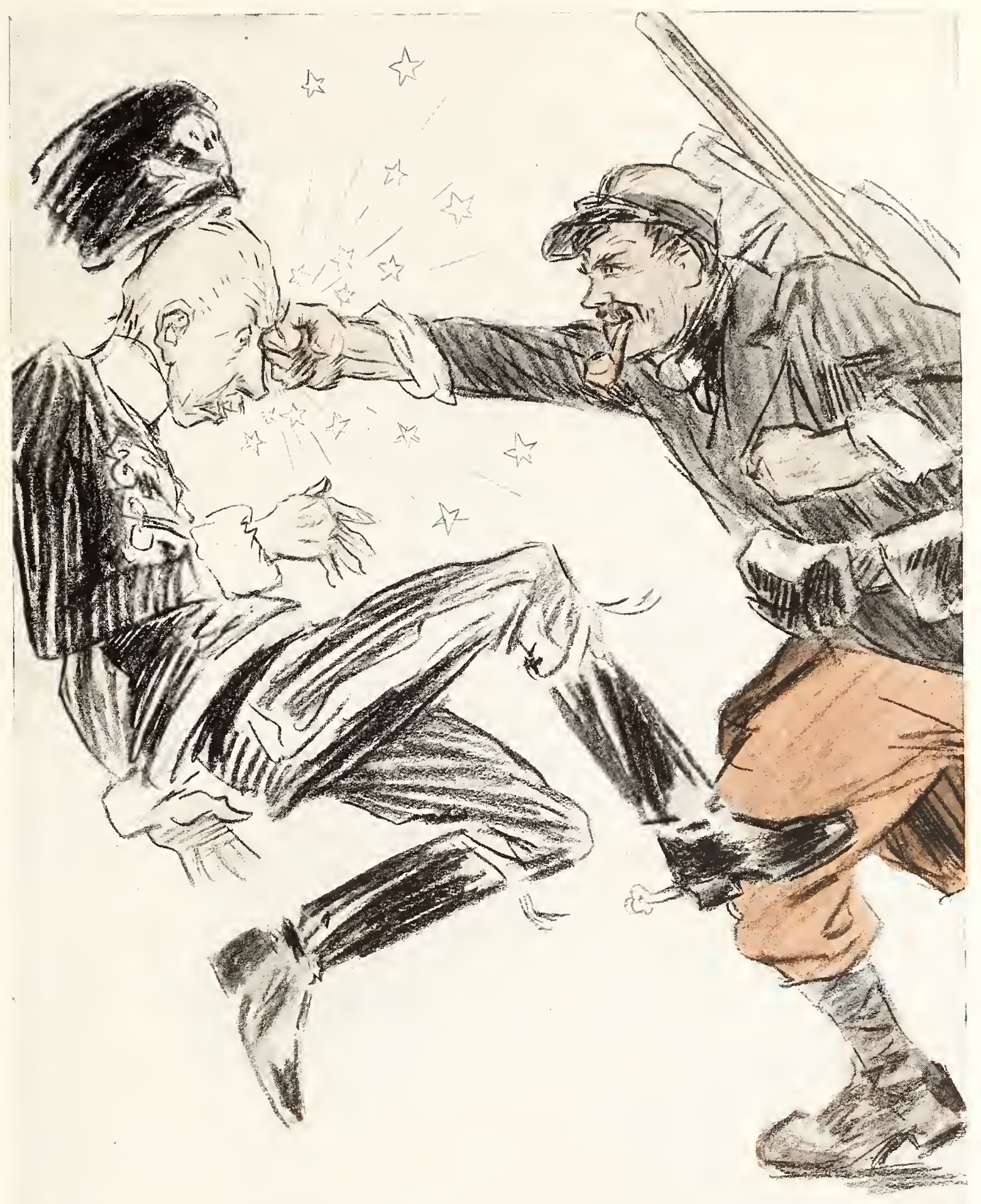

SEPTEMBER, 1914, AND SEPTEMBER, 1015

1914 : "Now the war begins as we like it."

1915: "But this is not as I wished it to continue."

(Published after the French success in Champagne.) 


\section{Liquid Fire}

W

HEN one sits down to think, there are few things in connection with the devastating War now raging, wild-beastlike, almost throughout the length and breadth of Europe, so appalling as the application of science and man's genius to the work of decimating the human species.

Early in the conflict, which is being fought for the basal principles of civilization and moral human conduct, one was made to realize that the Allied Powers were opposed to an enemy whose resources were only equalled by his utter negation of the rules of civilized warfare. Soon, to the horrors of machine-guns and of high-explosive shells of a calibre and intensity of destructive force never before known, were added the diabolical engines for pouring over the field of battle asphyxiating gases. We know the horrors of that mode of German "frightfulness," and some of us have seen its effects in the slowly dying victims in hospitals. But that was not enough. Yet other methods of "frightfulness" and savagery, which would have disgraced the most ruthless conquerors of old, were to be applied by the German Emperor in his blasphemous "Gott mit uns" campaign. And against the gallant sons of Belgium, France, England, and Russia in turn were poured out with bestial ingenuity the jets and curtains of "liquid fire" which seared the flesh and blinded the eyes. For this there will be a reckoning if God be still in heaven whilst the world trembles with the shock of conflict, and the souls of men are seared.

Raemaekers in this cartoon shows not only the horror of such a method of warfare, but also, with unerring pencil, the unwavering spirit of the men who have to meet this "frightfulness." There is a land to be redeemed, and women and children to be avenged, and so the fighting men of the allied nations go gallantly on with their stern, amazed faces set towards victory.

CLIVE HOLLAND. 


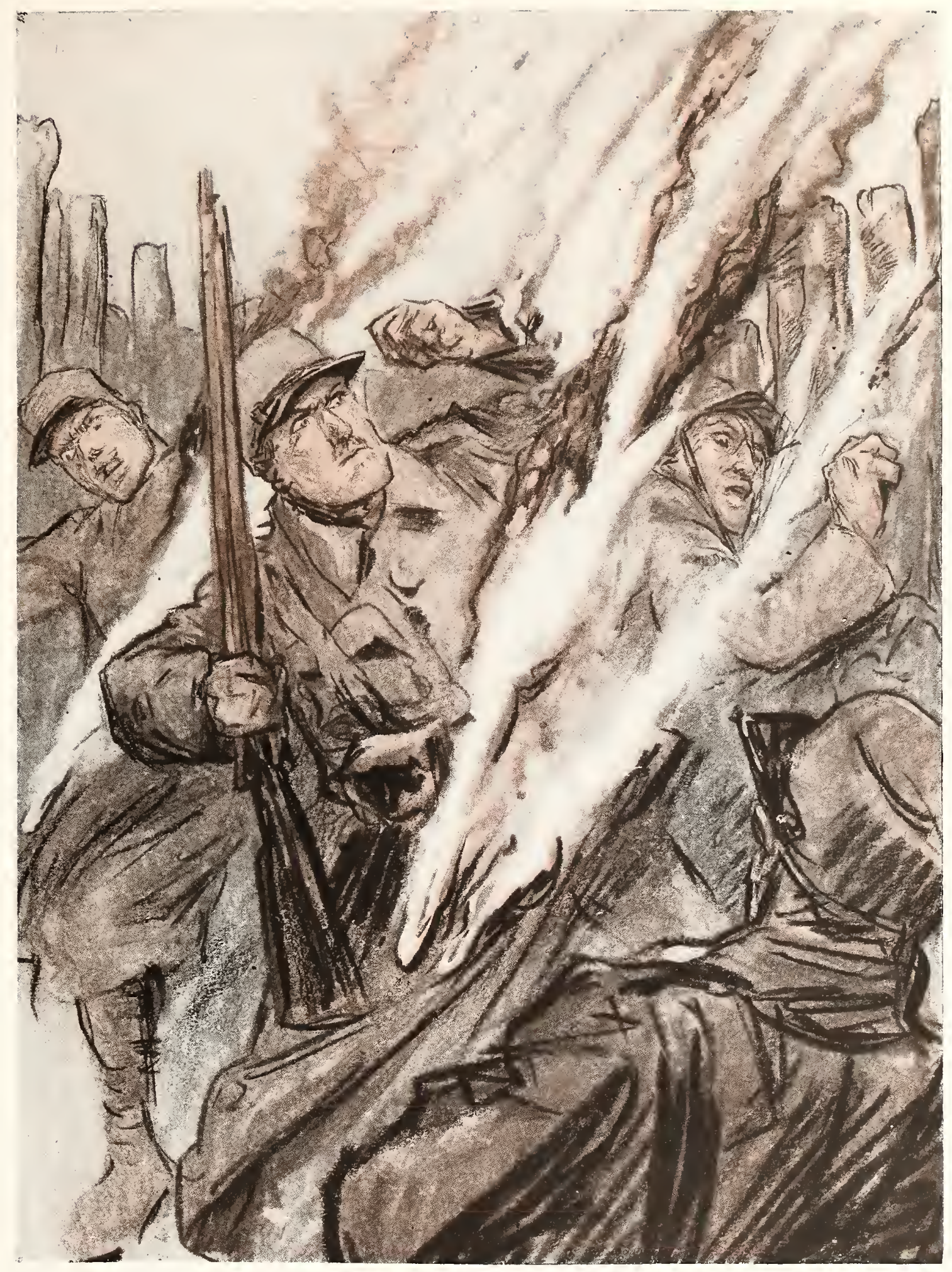

LIQUID FIRE 


\section{Nish and Paris}

$\mathrm{V}$

ERY happily and very graphically has Raemaekers here pointed the contrast between the Gargantuan hopes with which the Kaiser and his Junker army embarked on the War, and the exiguous and shadowy fruits of their boasted victories up to the present. They foretold a triumphal entry into the conquered capital of France within a month of the opening of hostilities. Yet the irony of Fate has, slowly but surely, cooled the early fever of anticipation. The only captured town where the All-IIighest has found an opportunity of lifting his voice in exultant pæan is Nish, a secondary city of the small kingdom of Serbia. There, too, he perforce delayed his jubilation until the lapse of some eighteen months after the date provisionally and prematurely fixed in the first ebullition of overconfidence, for his triumphal procession through Paris.

Nish is a town of little more than 20,000 inhabitants; about the size of Taunton or Hereford-smaller than Woking or Dartford. Working on a basis of comparative populations, the Emperor would have to repeat without more delay his bravery at Nish in 150 towns of the same size before he could convince his people that he is even now on the point of fulfilling his first rash promises to them of the rapid overthrow of his foes. Pursuing the same calculation, he is bound to multiply his present glories 350 times before he can count securely on spending a night as conquering hero in Buckingham Palace.

Even the Kaiser must know in his heart that woefully, from his own and his people's point of view, did he overestimate his strength at the outset. For the time he contents himself with the backwater of Nish for the scene of his oratory of conquest. His vainglorious words may well prove in their environment the prelude of a compulsory confession of failure, which is likely to come at a far briefer interval than the eighteen months which separate the imaginary hope of Paris from the slender substance of Nish.

SIDNEY LEE. 


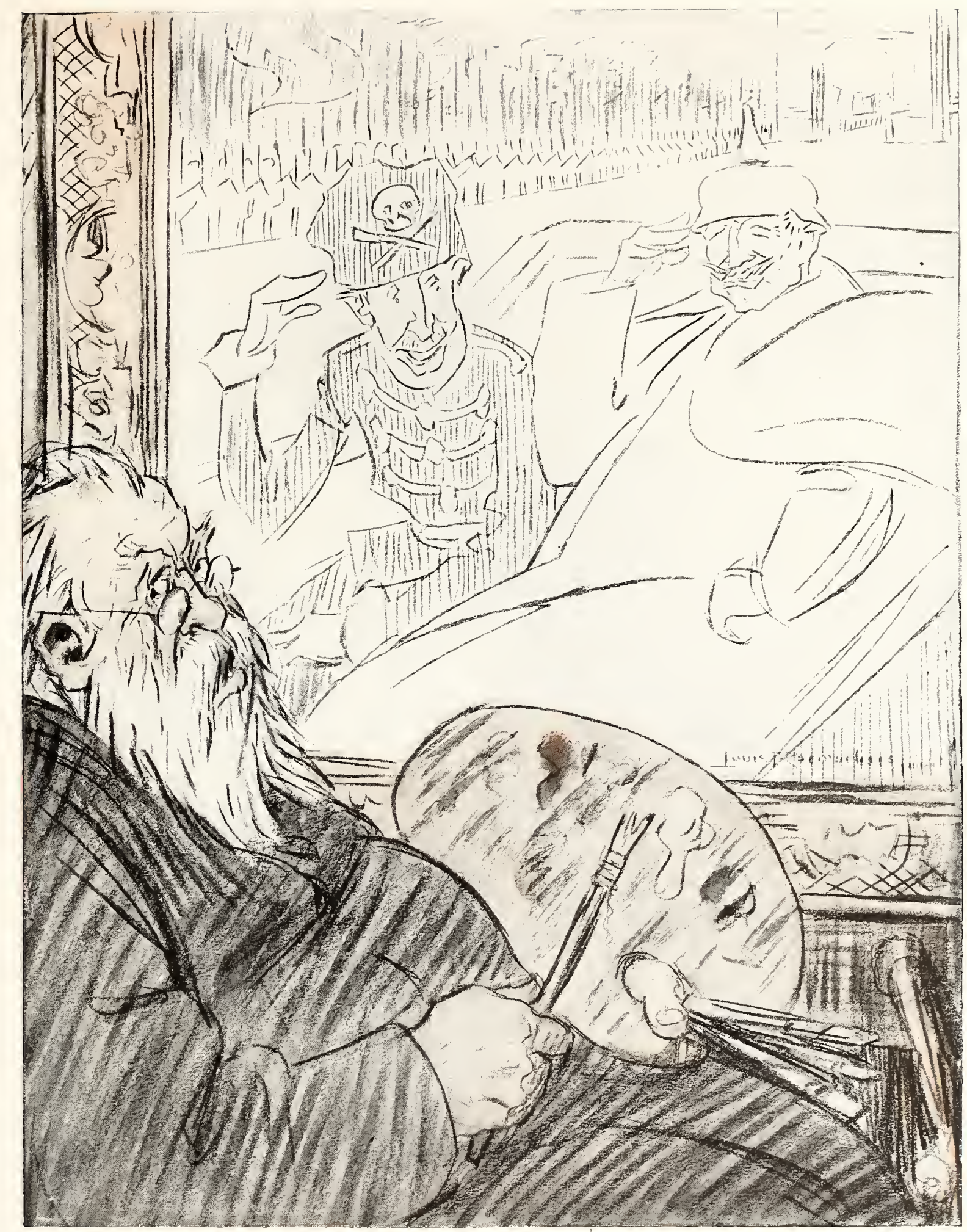

THE TRIALS OF A COURT PAINTER

"I commenced this as the entry into Paris, but I must finish it as the entry into Nish." 


\section{Gott Strafe England!}

T THESE sombre times one is grateful for a touch of humour, and it would perhaps be impossible to conceive in all created nature a spectacle so exquisitely ludicrous as the appearance of the Prussian in the guise of a Wronged Man. For, of course, it is the very foundation of the Prussian theory that there can be no such thing as a wronged man. Might is right. That which physical force has determined and shall determine is the only possible test of justice. That was the diabolic but at least coherent philosophy upon which the Kingdom of Prussia was originally based and upon which the German Empire created by Prussia always reposed.

Nor was that philosophy - which among other things dictated this war - ever questioned, much less abandoned, by the Germans so long as it seemed probable to the world and certain to them that they were destined to win. Now that it has begun to penetrate even into their mind that they are probably going to lose, we find them suddenly blossoming out as pacifists and humanitarians.

Especially are they indignant at the "cruelty" of the blockade. It is not necessary to examine seriously a contention so obviously absurd. Any one acquainted with the history of war knows the blockade of an enemy's ports is a thing as old as war itself. Every one acquainted with the records of the last half-century knows that Prussia owes half her prestige to the reduction of Paris in 1871-effected solely by the starvation of its civilian inhabitants.

But the irony goes deeper than that. Look at the face of the Prussian in "Raemaekers' Cartoons" and you will understand why Germans in America, Holland, and other neutral countries are now talking pacifism and exuding humanitarian sentiment. You will understand why the German Chancellor says that in spite of the victorious march of Germany from victory to victory his tender heart cannot but plead for the dreadful sufferings of the unhappy, though criminal, Allies. Then you will laugh; which is good in days like these.

CECIL CHESTERTON. 


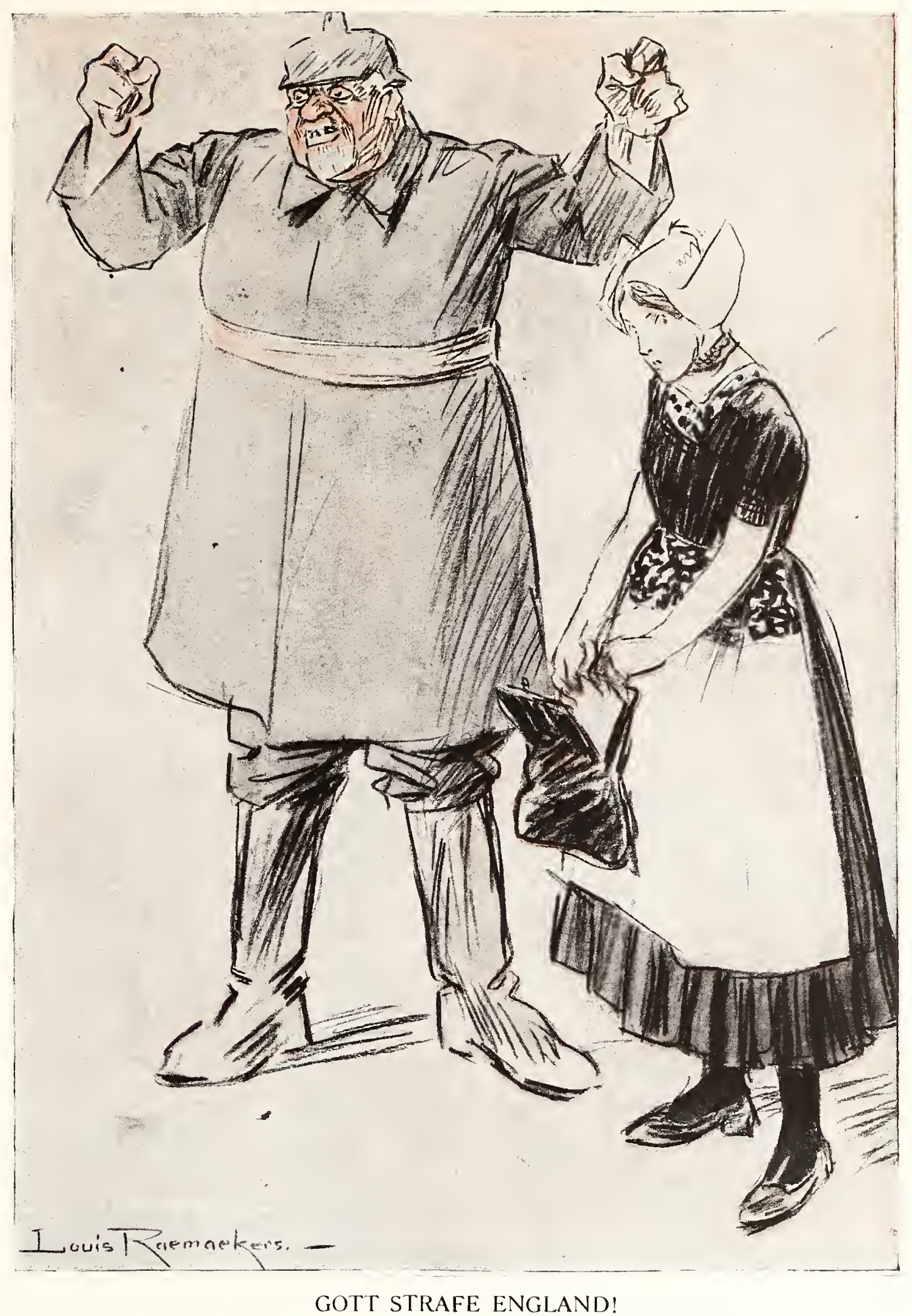

"Now she prevents my sending goods by the Holland route!" 


\section{The Pacificist Kaiser (The Confederates)}

$\mathrm{F}$ ROM time to time of late the Kaiser has posed as the champion of peace. His official spokesman, Chancellor Bethmann-Hollweg, has announced the Imperial readiness to stay the waron his master's own terms, which he disdains to define precisely.

The Emperor and his advisers are involved in a tangle of miscalculations which infest the conduct of the war alike in the field of battle and the council-chamber. But no wild imaginings could encourage a solid hope that the Chancellor's peaceful professions would be taken seriously by anybody save his own satellites. Loudly the compliant Minister vaunted in the Reichstag his country's military successes, but he could point to no signs either of any faltering in military preparations on the part of the Allies, or of their willingness to entertain humiliating conditions of peace.

Even in Germany clear visions acknowledge that Time is fighting valiantly on the side of Germany's foes, and that peace can only come when the Central Powers beg for it on their knees.

It is improbable that the Kaiser and his Chancellor now harbour many real illusions about the future, although they may well be anxious to disguise even to themselves the ultimate issues at stake in the war. Their home and foreign policy seens to be conceived in the desperate spirit of the gambler. They appear to be recklessly speculating on the chances of a pacificist rôle conciliating the sympathy of neutrals. They count on the odds that they may convert the public opinion of non-combatant nations to the erroneous belief that Germany is the conqueror, and that further resistance to her is futile. But so far the game has miscarried. The recent German professions of zeal for peace fell in neutral countries on deaf or impatient ears. The braggart bulletins of the German Press Bureau have been valued at their true worth. Neutral critics have found in Bethmann-Hollweg's cry for peace mere wasted breath

The Chancellor and his master are perilously near losing among neutrals the last shreds of reputation for political sagacity.

SIDNEY LEE. 


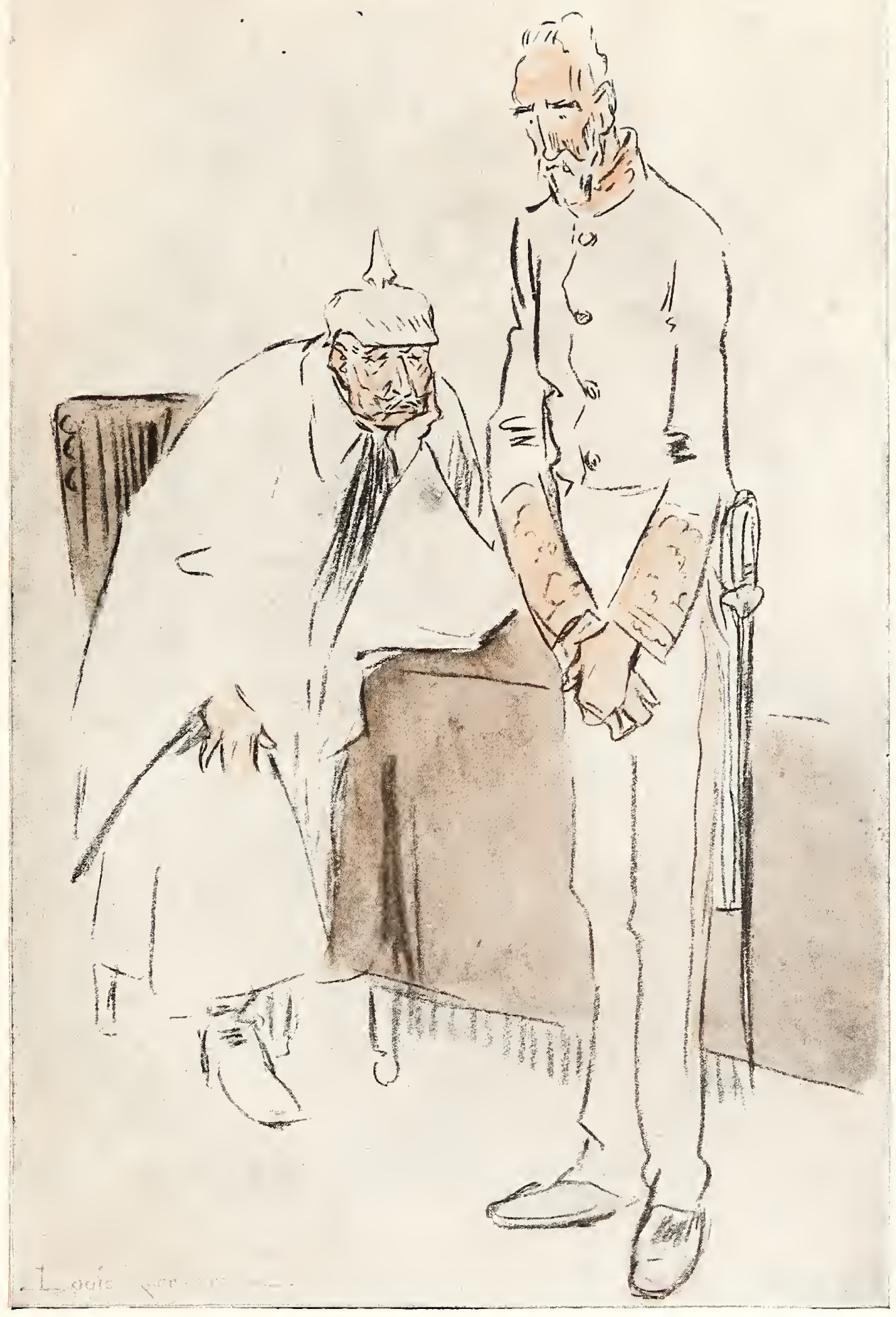

THE CONFEDERATES

"Did they believe that peace story in the Reichstag, Bethmann?" "Yes, but the Allies didn't." 


\section{Dinant}

$\mathrm{D}$ URING the joint expedition to Peking, all the olher contingents were horrified at the cruelty of the German troops. I have heard how on one occasion a number of Chinese women were watching a German regiment at drill, when suddenly the commanding officer ordered his men to open fire upon them. When remonstrated with, he replied that terrorism was humane in the end, because it made the enemy desire peace. For some reason, these atrocities were not very widely known in England; and no one dreamed that such infernal crimes would ever be perpetrated in European war. But such are indeed the calculated methods of Germany; and her officers began to order them as soon as her troops crossed the Belgian frontier. The German military authorities advise that terrorism should be used sparingly when there is danger of reprisals. Accordingly, though many abominable things have been done to civilians in France and Russia, and to ourselves when opportunity offered, the worst atrocities were committed in Belgium, because Belgium is a small country, which had dispensed with universal military service in reliance on the international guarantee of her security. These events of the first month of the war are in danger of being forgotten, now that Germany is contending on equal terms against the great nations of Europe. But they must not be forgotten. We are fighting against a nation which thinks it good policy to massacre non-combatants, provided only that the sons and brothers of the victims are not in a position to retaliate.

W. R. INGE. 


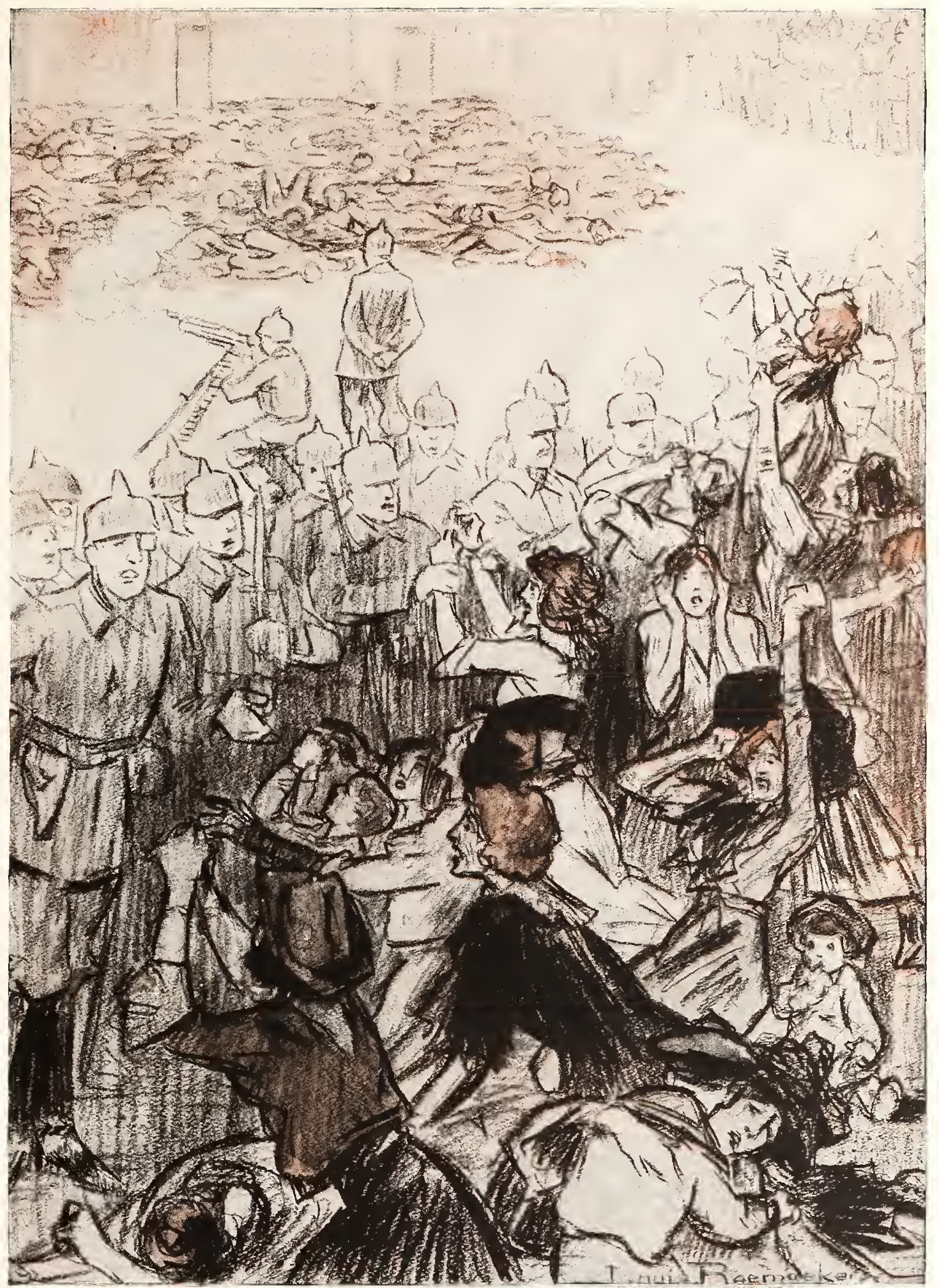

DINANT-I SEE FATHER. 


\section{"Hesperia" (Wounded First)}

AILORS of all nationality except German have from time im$S$ memorial looked upon themselves as the guardians and protectors of land folk at sea.

That is why every sailor in the world, outside the doggeries of Hamburg, felt his calling spat upon and his personal pride injured by the sinking of the Lusitania-by a sailor.

It seemed that nothing could be worse than that, and then came the sinking of the Hesperia, a ship filled with wounded soldiers and Hospital nurses.

Raemaekers brings the fact home to us in this cartoon, not the fact of the English nurses' heroism, which goes without saying, but of German low-down common infamy. The fact has become so commonplace, so accustomed, so everyday that pictures of burning cathedrals, murdered children, and terrified women no longer move us as they did, but this artist, whose command of language seems as infinite and varied as the crimes of the criminals whom God sent him to scourge, has always some stroke in reserve, something to add to what he has said, if need be. In the case of this picture it is the medicine bottle, glass, and spoon flying off the shelf, flung to the floor by the bursting charge of Tri-nitro-toluine that adds the last touch as distinctive as the artist's signature.

H. DE VERE STACPOOLE. 


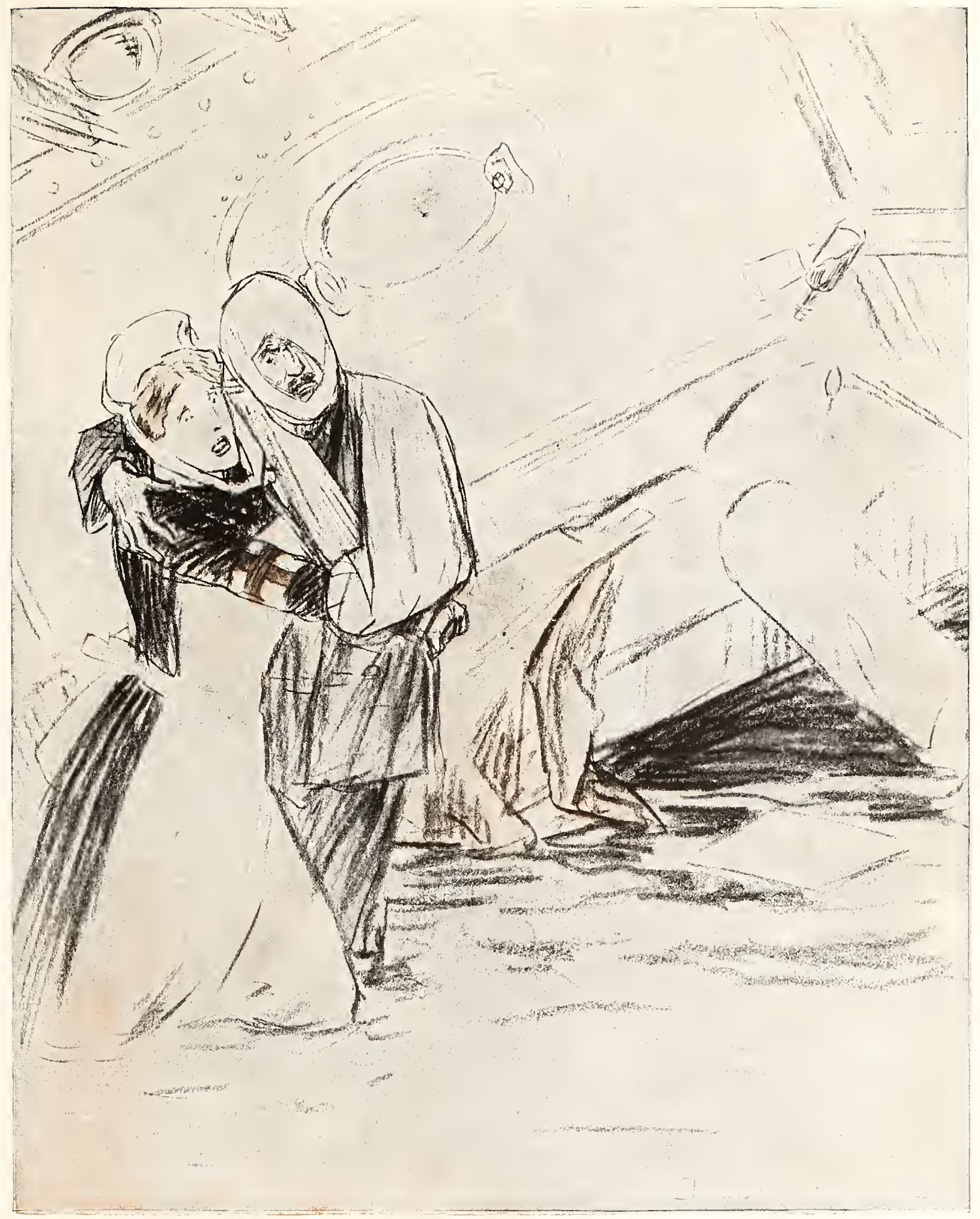

Another kind of heroisim - the sinking of the Hospital Ship Hesperia (Wounded First) 


\section{Gallipoli}

T T IS a fine touch, or a fortunate accident, in this sketch of Raemaekers' that it depicts the officer who has made the mistake as exhibiting the spruceness of a Prussian, and the officer who has found out the mistake as having the comparatively battered look of an old Turk. The moustaches of the Young Turk are modelled on the Kaiser's, spikes pointing to heaven like spires; while those of his justly incensed superior officer hang loose like those of a human being. The difference is in any case symbolic; for the sort of instinctive and instantaneous self-laudation satirized in this cartoon is much more one of the vices of the new Germany than of the antiquated Islam. That spirit is not easy to define; and it is easy to confuse it with much more pardonable things. Every people can be jingo and vainglorious; it is the mark of this spirit that the instinct to be so acts before any other instinct can act, even those of surprise or anger. Every people emphasizes and exaggerates its victories more than its defeats. But this spirit emphasizes its defeats as victories. Every national calamity has its consolations; and a nation naturally turns to them as soon as it reasonably can. But it is the stamp of this spirit that it always thinks of the consolation before it even thinks of the calamity. It abounds throughout the whole press of the German Empire. But it is most shortly shown in this figure of the young officer, who makes a hero of himself before he has even fully realized that he has made a fool of himself.

G. K. CHESTERTON. 


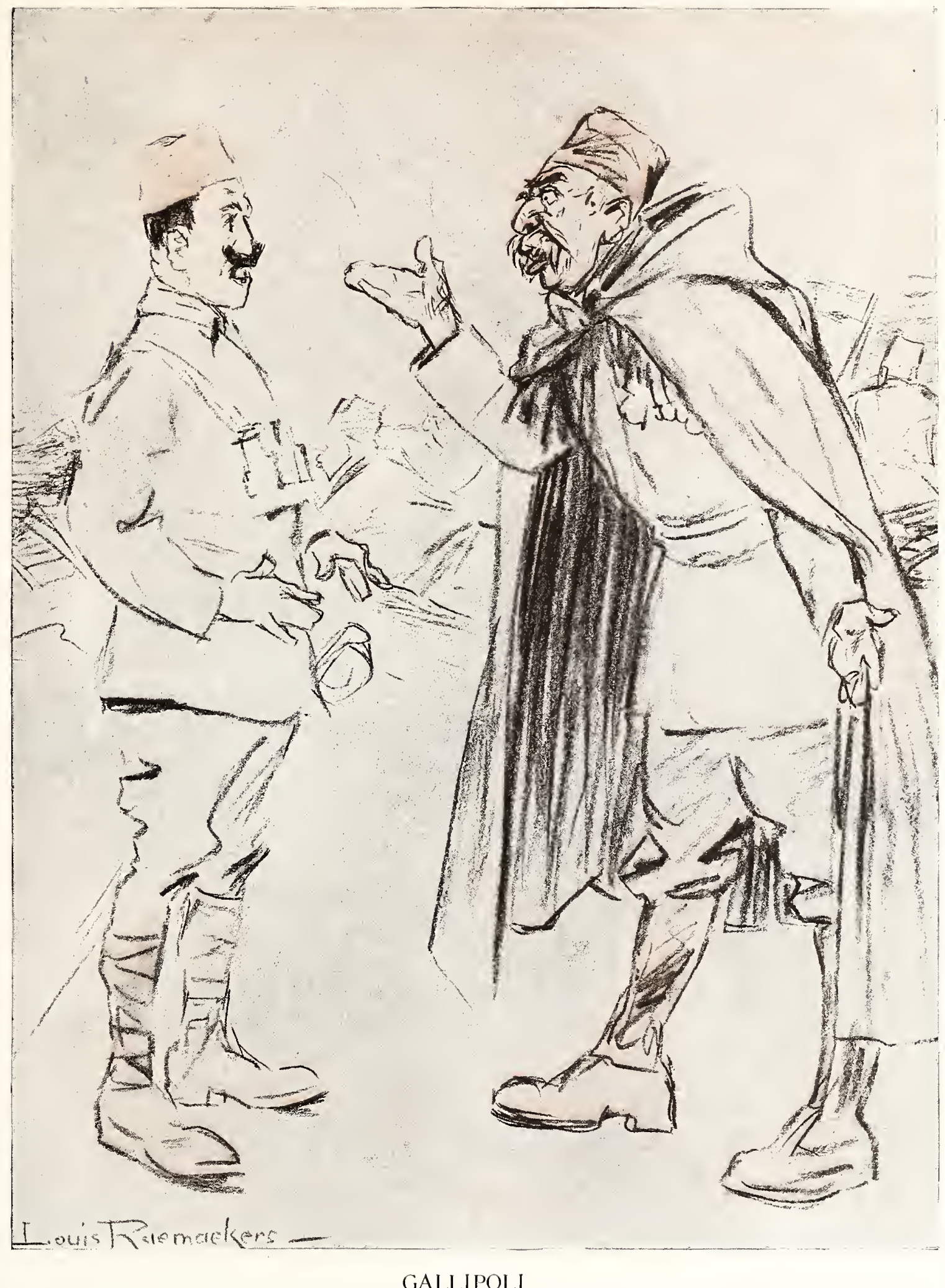

Turkish General: "What are you firing at? The British evacuated the place twenty-four hours ago!"

"Sorry, sir-but what a glorious victory! 


\section{The Beginning of the Expiation}

I T IS sometimes an unpleasant necessity to insult a man, in order to make him understand that he is being insulted. Indeed, most strenuous and successful appeals to an oppressed populace have involved something of this paradox. We talk of the demagogue flattering the mob; but the most successful demagogue generally abuses it. The men of the crowd rise in revolt, not when they are addressed as "Citizens!" but when they are addressed as "Slaves!"

If this be true even of men daily disturbed by material discomfort and discontent, it is much truer of those cases, not uncommon in history, in which the slave has been soothed with all the external pomp and luxury of a lord. So prophets have denounced the wanton in a palace or the puppet on a throne; and so the Dutch caricaturist denounces the gilded captivity of the Austrian Monarchy, of which the golden trappings are golden chains.

But for such a purpose a caricaturist is better than a prophet, and comic pictures better than poetical phrases. It is very vital and wholesome, even for his own sake, to insult the Austrian. He ought to be insulted because he is so much more respectable than the Prussian, who ought not to be insulted, but only kicked. If Austria feels no shame in letting the Holy Roman Empire become the petty province of an Unholy Barbarian Empire, if such high historic symbols no longer affect her, we can only tell her, in as ugly a picture as possible, that she is a lackey carrying luggage.

G. K. Chesterton. 


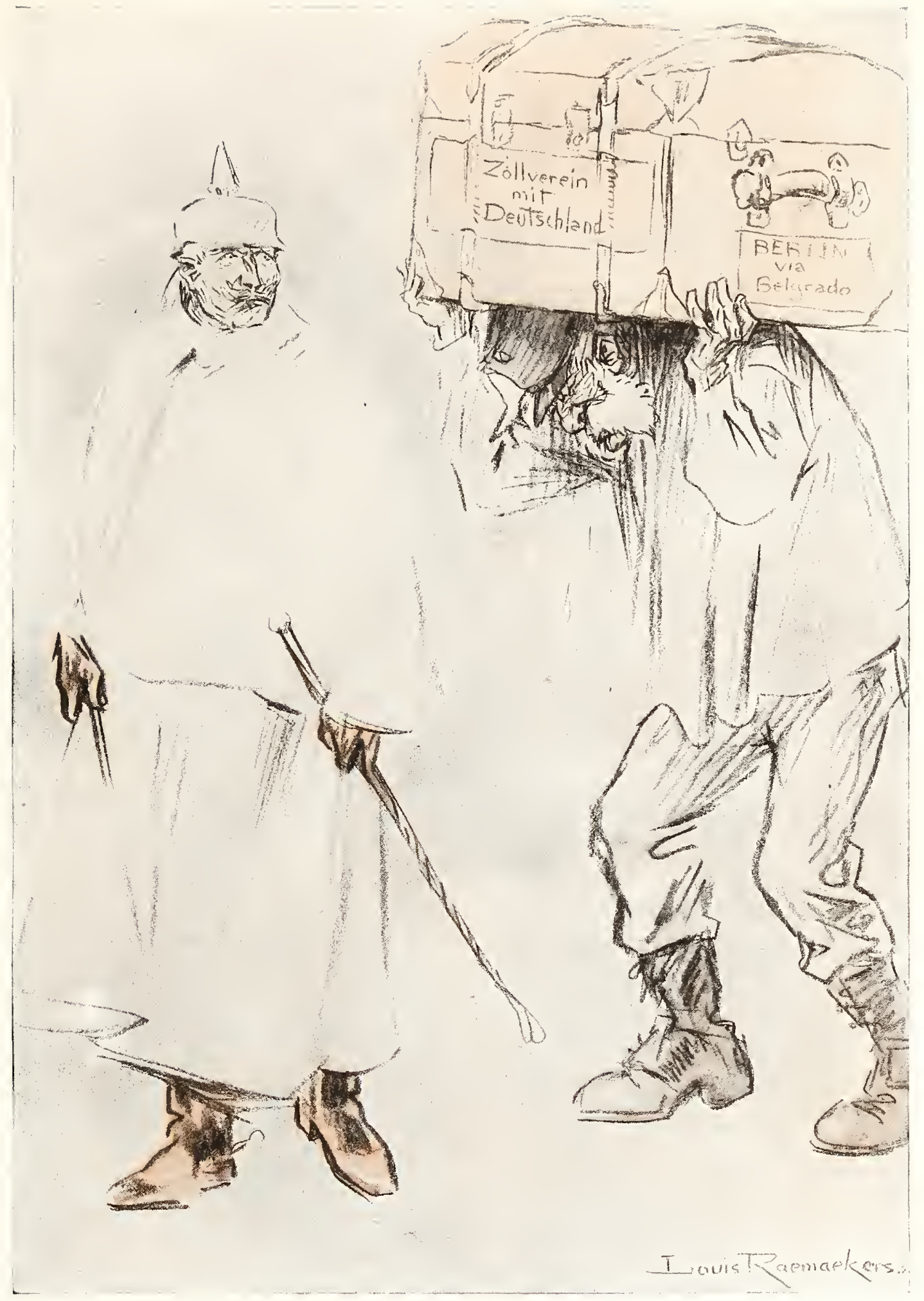

THE BEGINNING OF THE EXPIATION 


\section{The Shirkers}

C URRENT experience is proving that war is a grim condition of life, and that none can escape its effects. No religious or philosophic precept is potent enough in practical application to prevent its outbreak or to stay its course. The strong man of military age, who claims the right to pursue normal peaceful avocations when his country is at war, pleads guilty, however involuntarily, to aberrations of both mind and heart.

There are few who do not conscientiously cherish repugnance for war, but practically none of those to whom so natural a sentiment makes most forcible appeal deem it a man's part to refuse a manifest personal call of natural duty. The conscientious objector to combatant service may in certain rare cases deserve considerate treatment, but very short shrift should await the able-bodied men who, from love of ease or fear of danger, simulate conscientious objection in order to evade a righteous obligation.

Lack of imagination may be at times as responsible for the sin of the shirker as lack of courage. Patriotism is an instinct which works as sluggishly among the unimaginative as among the cowardly and the selfish. The only cure for the sluggish working of the patriotic instinct among the cowardly and the selfish is the sharp stimulus of condign punishment. But among the unimaginative it may be worth experimenting by way of preliminary with earnest and urgent appeals to example such as is offered not only by current experience, but also by literature and history. No shirkers would be left if every subject of the Crown were taught to apprehend the significance of Henley's interrogation:

What have I done for you,

England, my England?

What is there I would not do,

England, my own?

SIDNEY LEE. 


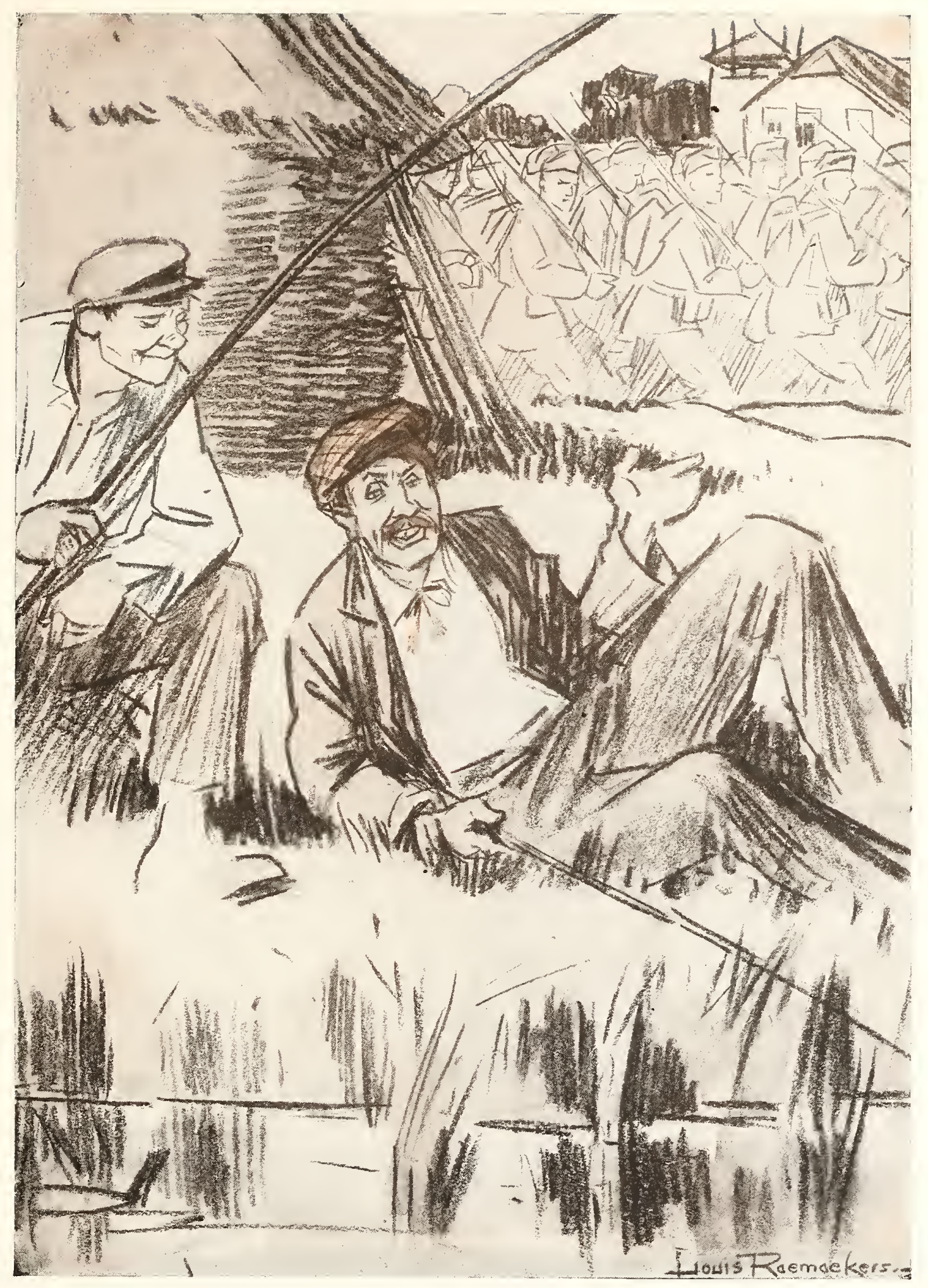

THE SHIRKERS 


\section{One of the Kaiser's Many Mistakes}

TOUIS BOTHA - we touch our hats to you!

You are supremely and triumphantly one of the Kaiser's many mistakes. You have proved yourself once again a capable leader and a man among men. You have proved him once more incapable of apprehending the meaning of the word honour. You are an honourable man. Even as a foe you fought us fair and we honoured you. You have valiantly helped to dig the grave of his dishonour and have proved him a fool. We thank you! And we thank the memory of the clear-visioned men of those old days who, in spite of the clamour of the bats, persisted in tendering you and yours that right hand of friendship which you have so nobly justified.

You fought us fair. You have uprisen from the ashes of the past like the Phœnix of old. You are Briton with the best.

Fair fight breeds no ill-will. It is the man, and the nation, that fights foul and flings God and humanity overboard that lays up for itself stores of hatred and outcastry and scorn which the ages shall hardly efface.

And Germany once was great, and might have been greater.

Delenda est Germania! - so far as Germania represents the Devil and all his works.

The following lines were written fourteen years ago when we welcomed the end of the Boer War. We are all grateful that the hope therein expressed has been so amply fulfilled. That it has been so is largely due to the wisdom and statesmanship of Louis Botha.

No matter now the rights and wrongs of it;

You fought us bravely and we fought you fair.

The fight is done. Grip hands! No malice bear!

We greet you, brothers, to the nobler strife

Of building up the newer, larger life!

Join hands! Join hands! Ye nations of the stock!

And make henceforth a mighty Trust for Peace:-

A great enduring peace that shall withstand

The shocks of time and circumstance; and every land

Shall rise and bless you - and shall never cease

To bless you - for that glorious gift of Peace.

Germany, if she had so willed, could have come into that hopedfor Trust for Peace.

But Germany would not. She put her own selfish interests before all else and so digs her own grave.

JOHN OXENHAM. 


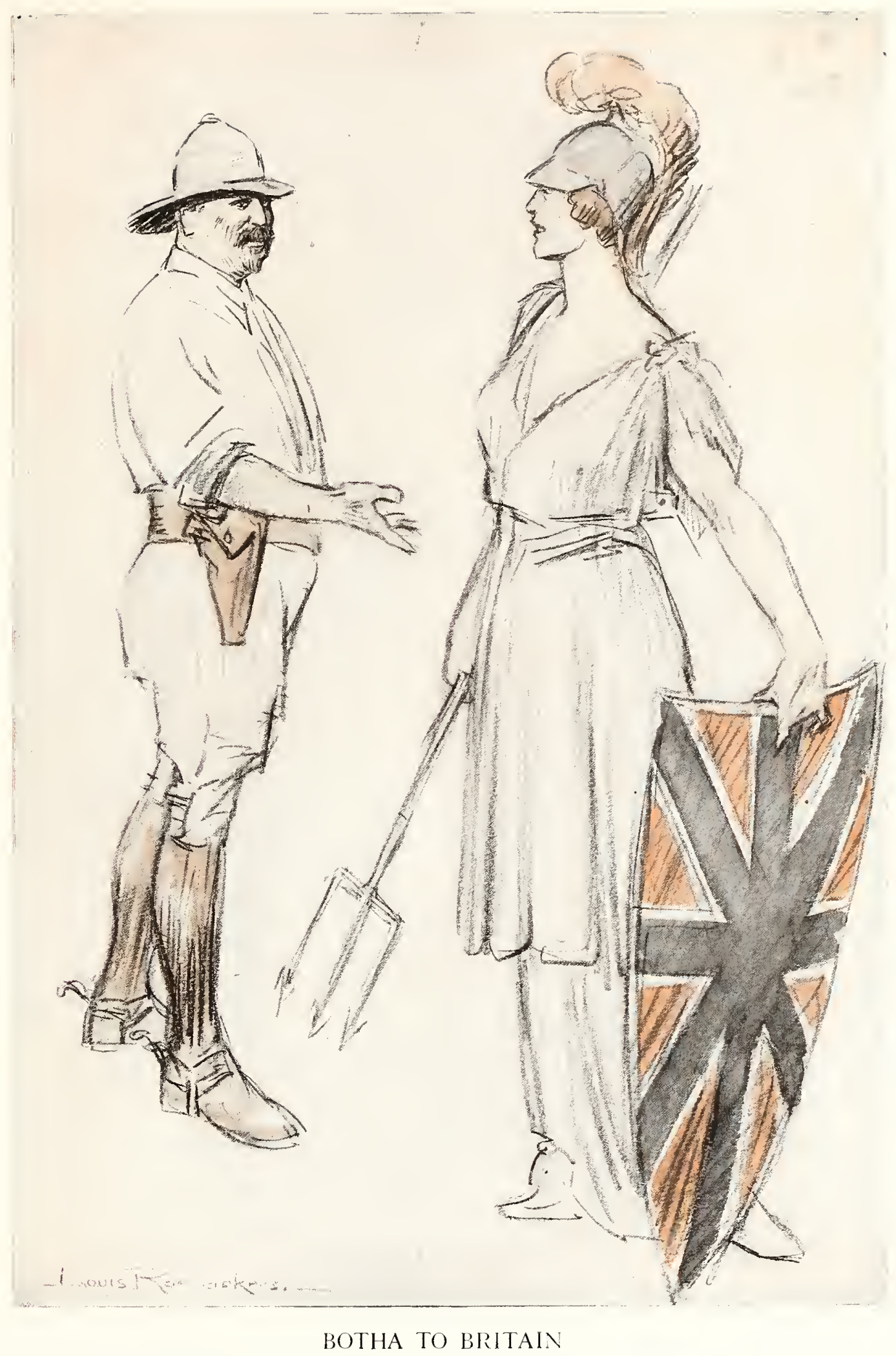

"I have carried out everything in accordance with our compact at Vereeniging." 


\section{Belgium in Holland}

T THE present crisis of Belgian affairs there is much to remind the historical student of the events which led to the fall of Antwerp in 1585, and the outrageous invasion of the Southern Netherlands by the army of Parma. Then, as now, Holland opened her arms to her wounded and captive sister. The best Flemish scholars and men of letters emigrated to the land where Cornheert and Spieghel welcomed them.

Merchants and artisans flocked to a new sphere of energy in Amsterdam. Several of the professorial chairs in that city, and in the great universities of Leyden and Harderwijk, were filled by learned Flemings, and the arts, that had long been flourishing in Brussels, fled northward to escape from the desolating Spanish scourge. The grim pencil of Raemaekers becomes tender whenever he touches upon the relation of the tortured Belgium to her sister, Holland, his own beloved fatherland.

We do not know yet, in this country, a tithe of the sacrifices which have been made in Holland to staunch the tears of Belgium. "Your sufferings are mine, and so are your fortunes," has been the motto of the loyal Dutch.

EDMUND GOSSE. 


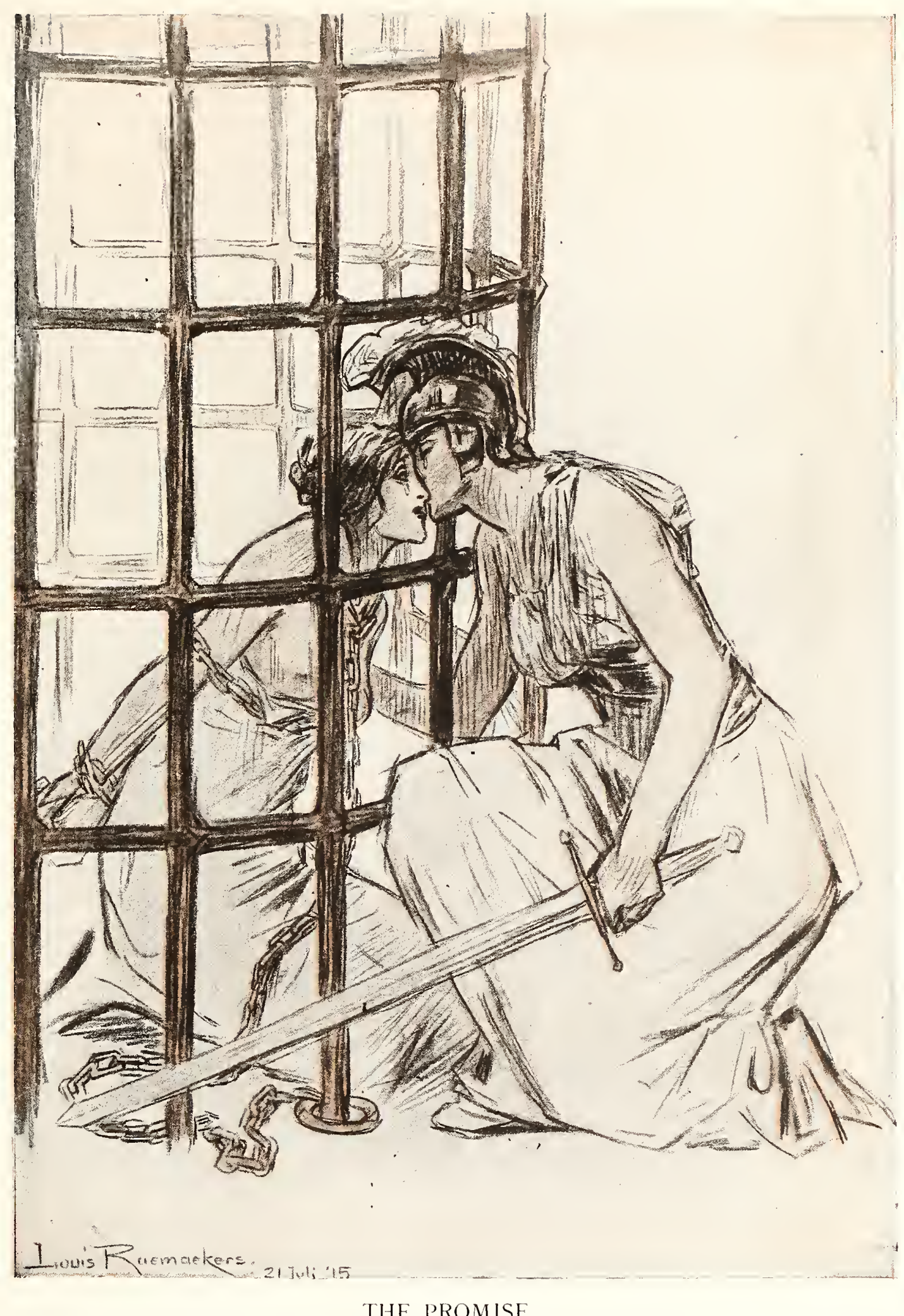

THE PROMISE

"We shall never sheath the sword until Belgium recovers all, and more than all that she has sacrificed."-Mr. Asquith, 9th November, 1914. 


\section{Serbia}

$\mathrm{T}$

IE fight of the one and the four might, in view of the difference in the size of the combatants, be called quite fairly "the fight of the one and the fifty-three." Each of the assailants has his own character. Germany is represented as a ferocious giant; Austria follows Prussia's lead, a little the worse for wear, with a bandaged head as the souvenir of his former campaign: he does his best to look and act like Germany. Bulgaria loses not a moment, but puts his rifle to his shoulder to shoot the small enemy: he acts in his own way, according to his own character: kill the enemy as quickly as possible and seize the spoil, that is his principle. Turkey is a rather brokendown and dilapidated figure, who is preparing to use his bayonet, but has not got it quite ready. Serbia, erect, with feet firmly planted, stands facing the chief enemy, a little David against this big Goliath and his henchman, Austria; and the other two, so recently deadly foes, now standing shoulder to shoulder, attack him while his attention is directed on Germany.

The leader and "hero" of this assault is Prussia, big, brutal, remorseless. The Dutch artist always concentrates the spectator's attention on him. You can almost hear the roar coming out of his mouth: "Gott strafe Serbien." This is the figure, as Raemaekers paints him, that goes straight for his object, regardless of moral considerations. Serbia is in his way, and Serbia must be trampled in the mire. The artist's sympathy is wholly with Serbia, who is pictured as the man fighting against the brute, slight but active and noble in build, facing this burly foe.

And poor old Turkey! Always a figure of comedy, never ready in time, always ineffective, never fully able to use the weapons of socalled "civilization." Let it always be remembered that in the Gallipoli peninsula, when the Turks at first were taking no prisoners, but killing the wounded after their own familiar fashion with mutilation, for the sake of such spoil as could be carried away, Enver Pasha issued an order that thirty piastres should be paid for every prisoner brought in alive, a noble and humane regulation. Let us hope that the reward was always paid, not stolen on the way, as has been so often the case in Turkey.

WILLIAM MITCHELL RAMSAY. 


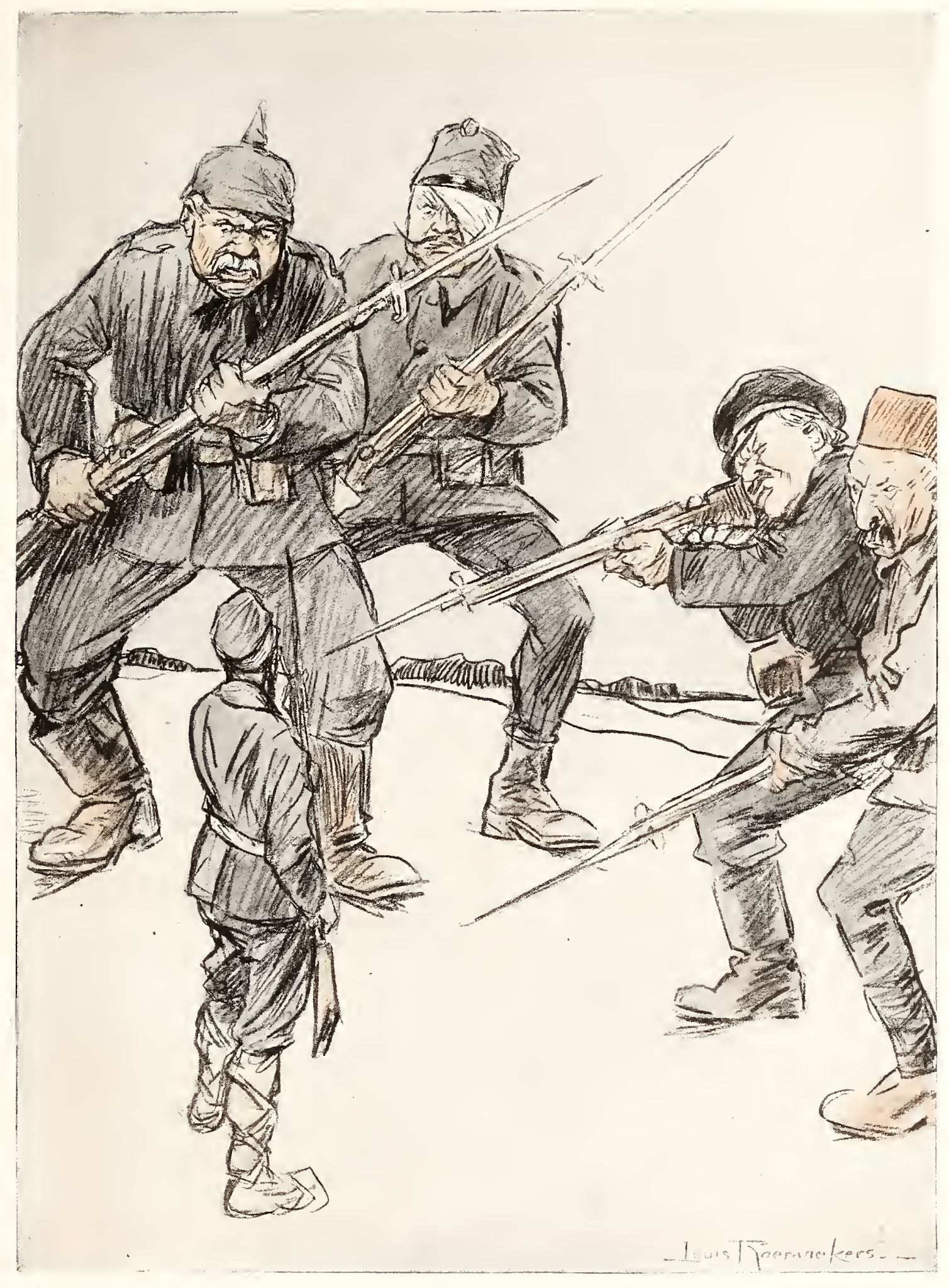

SERBIA

"Now we can make an end of him." 


\section{Jackals in the Political Field}

W

HEN the tiger," says the naturalist, "has killed some large animal, such as a buffalo which he cannot consume at one time, the jackals collect round the carcase at a respectful distance and wait patiently until the tiger moves off. Then they rush from all directions, carousing upon the slaughtered buffalo, each anxious to eat as much as it can contain in the shortest time."

The human jackal is one of the most squalid and sordid creatures and features of war. We saw him in Dublin the other day emerging from his slum den to loot Sackville Street. Every battlefield feeds its carrion beasts and birds.

This picture of Belgium and its jackals is doubtless only too true. Mr. Raemakers and the Dutch have better means of knowing than we. The jackal, says the same naturalist, belongs to the Canidx, the "dog tribe." The scientific name of the true dog is Canis familiaris, "the household dog." The jackal is Canis aureus, the "gold dog." The epithet describes no doubt his colour. The human Canis aureus perhaps deserves his title on not less obvious grounds.

"The continent of Europe," the naturalist goes on, "is free from the jackal." It was supposed till yesterday to be free from the lion and tiger.

But in the prehistoric times of the cave man, geologists say, there was both in England and Europe the great "sabre-tooth" tiger. Kipling, who knows everything about beasts, knows him and puts him into his "Story of Ung": "The sabre-tooth tiger dragging a man to his lair."

To-day the cave tiger has come back and with him the cave jackal. There is a terrible beauty about the tiger. The jackal is a mean and hideous brute. But both are out of date. Did not Monsieur Capus say the other day that Europe "cannot allow a return of the cave epoch?",

HERBERT WARREN. 


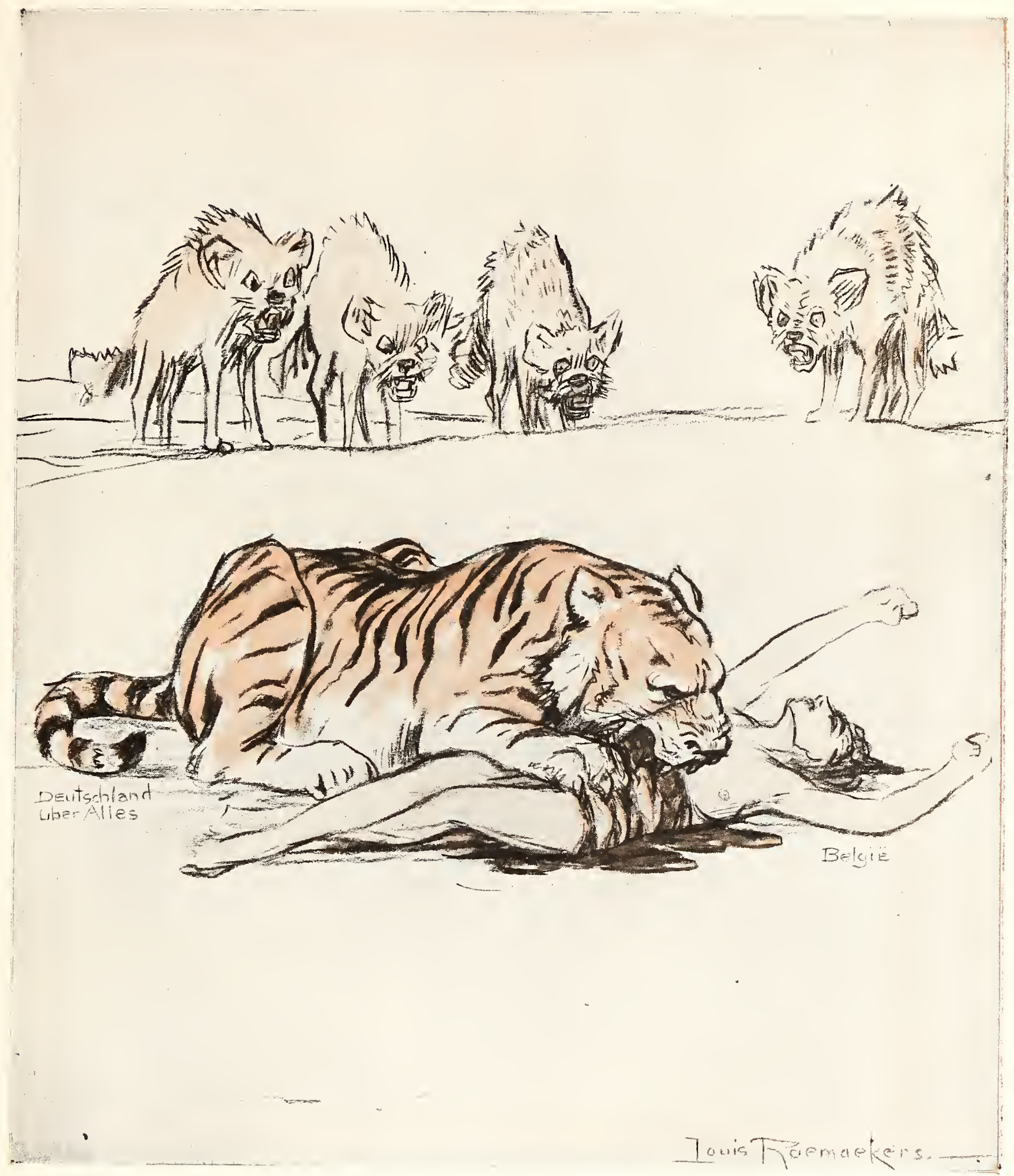

JACKALS IN THE POLITICAL FIELD

JaCkals (Flemish Pro-Germans): "What he leaves of Belgium will be enough for us." 


\section{A Letter from the German Trenches}

IN THIS cartoon Raemaekers has contrived to indicate powerfully what is after all the dominant and peculiar note of the German people. No European nation has ever taken war-as people say --so "seriously," that is, with so much concentration of attention and elaborate preparation, as has the German Empire. No people has ever had it so thoroughly drilled into its collective mind as have the German subjects of that Empire that war is not only, as all Christian people have always believed, an expedient lawful and necessary upon occasion, but a thing highly desirable in itself, nay, the principal function of a "superior" race and the main end of its being.

And yet after all the actual German is never, like the Frenchman, a natural and instinctive warrior-any more than he is, like the Englishman, a natural and instinctive adventurer. The whole business of Prussian militarism, with the half-witted philosophy by which it is justified, has to be imposed upon him from without by his masters. He fights just as he works, just as he tortures, violates, and murders, because he is told to do so by persons in a superior position, holding themselves stiffly, dressed in uniform, and able to hit him in the face with a whip.

Long before the war the absurd Koepenick incident gave us a glimpse of this astonishing docility on its farcical side. Its tragic side is well illustrated by the droves of helpless and inarticulate barbarians driven into the shambles daily (as at Verdun) for the sole purpose of covering up the blunders of their very "efficient" superiors. One could pity the wretches if there were not so considerable a leaven of wickedness in their stupidity.

CECIL CHESTERTON. 


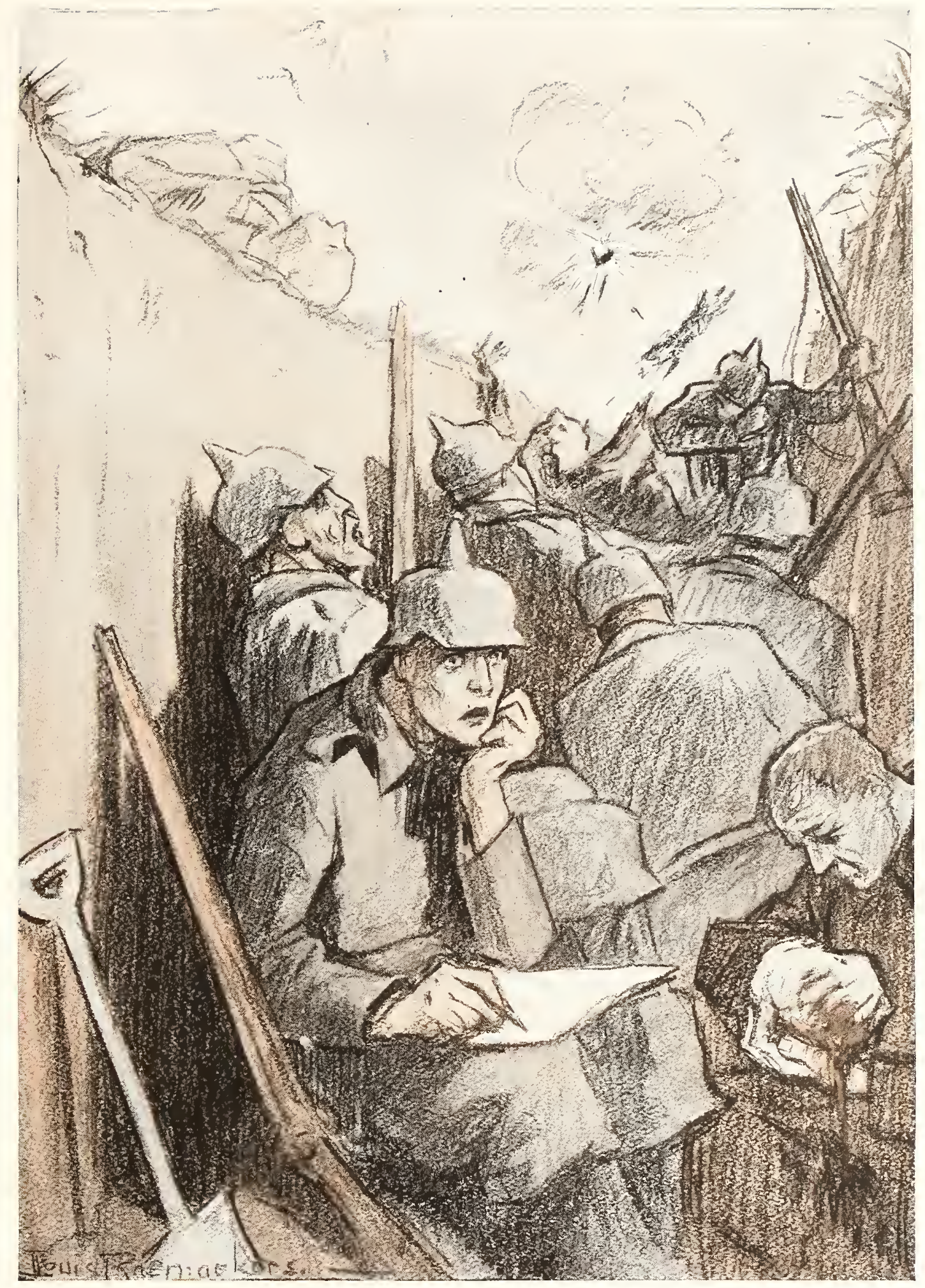

A LETTER FROM THE GERMAN TRENCHES

"We have gained a good bit; our cemeteries now extend as far as the sea." 


\section{His Master's Voice}

$\mathrm{T}$

HE manipulation of the Press is one of the weapons which Bismarck taught German Imperialism to use. Like others it has been developed by his successors into an instrument which the master himself would hardly have recognized. It is one of the most potent means of that "peaceful penetration" of all other countries which was nothing but a preparation for war. And it has been used in the war with a purposefulness of aim and a versatility of method that betoken long and systematic study. It is a ubiquitous influence and the most subtle of all. Yet the Press is held in greater contempt by official and other ruling circles in Germany than in any other country. They despise the tool, while tacitly acknowledging its utility by unsparing use.

This curious state of things is the fault of the Press. What has rendered it such a pliant tool in the hands of German Imperialism is either credulity or venality; and both are contemptible qualities. Credulity is probably the more prevalent, at least in this country, where shoals of newspapers, blinded by their own prejudices, were the dupes of German duplicity. But there has been venality, too, both crude and subtle. The case of the "Vlaamsche Sten," here satirized by Raemaekers, is exceptional. So crude and gross a method of influencing the Press as bribing the proprietor of a newspaper (probably with the aid of threats) to hand it over with its staff and goodwill could hardly be practised where any independence survived. It was not practised with success even in conquered Flanders, for the staff, to their eternal credit, refused to listen to the new master's voice. But there are journalists who, less intelligent than the terrier, faithfully accept the voice from the Pickelhaube and wag their little tails when they hear it. To them is offered the parable which shows their relation to their master.

A. SHAD IVELL. 


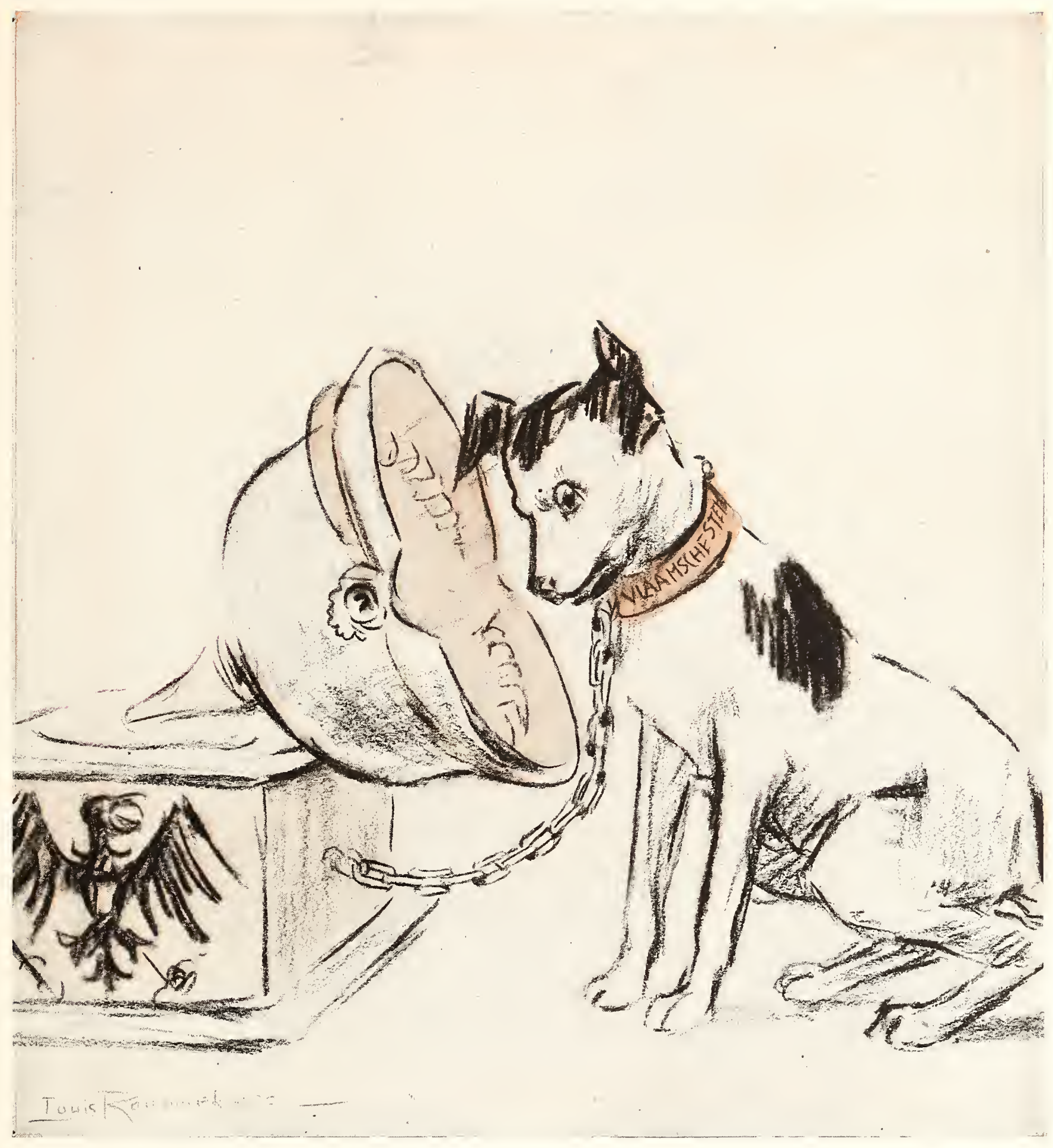

HIS MASTER'S VOICE

The Vlaamscbe Stem (Flemish Voice), a Flemish paper, was bought by the Germans, whereupon the whole staff resigned, as it no longer represented its title. 


\section{Hun Generosity}

$\mathrm{T}$ HE All-Highest, so we are told, loves a joke at another's expense, a trait in his character essentially barbaric. Raemaekers reproduces the twinkle in the Imperial eye as William of Potsdam offers to a quondam ally the foot which belongs to his senile and helpless brother of Hapsburg. The roar of anguish from the prostrate octogenarian provokes, as we see, not pity but a grim smile. Italy's monarch, we may imagine, is muttering to himself :-

\section{Timeo Danaos et dona ferentes.}

The bribe, wrenched from another, was, of course, indignantly rejected, but one wonders what the secret feelings of the Hapsburgs may be toward the Hohenzollerns. We know that the Turk cherishes no love for the Hun who has beguiled him, but we cannot gauge as yet the real strength or weakness of the bond between the Huns on the one hand and the Austrians and Hungarians on the other. Raemaekers has portrayed Franz Josef flat on his back. In the language of the ring he is "down and out." Possibly it may have been so from the beginning. At any rate, in this country, there is an amiable disposition to regard Franz Josef as a victim rather than an accomplice, a weakling writhing beneath the jack-boot of Prussia, impotent to hold his own. It may not be so. Time alone will reveal the truth.

But this much is reasonably certain. When peace is declared, the sincere friendship which once existed between ourselves and the Dual Monarchy may be reëstablished, but many years must pass before we forgive or forget the Huns. They are boasting to-day that as a nation they are self-sufficing and self-supporting. Amen! Most of us desire nothing better than to leave them alone till they have mended their manners and purged themselves of a colossal and unendurable conceit. I cannot envisage Huns playing tennis at Wimbledon, or English girls studying music at Leipzig. The grass in the streets of Homburg will not, for many years, be trodden out by English feet; the harpies of hotel keepers throughout the Happy Fatherland will prey, it may be presumed, upon their fellow Huns. Then they will fall to "strafing" each other instead of England. And then, as now, their mouthings will provoke inextinguishable laughter.

HORACE ANNESLEY VACHELL. 


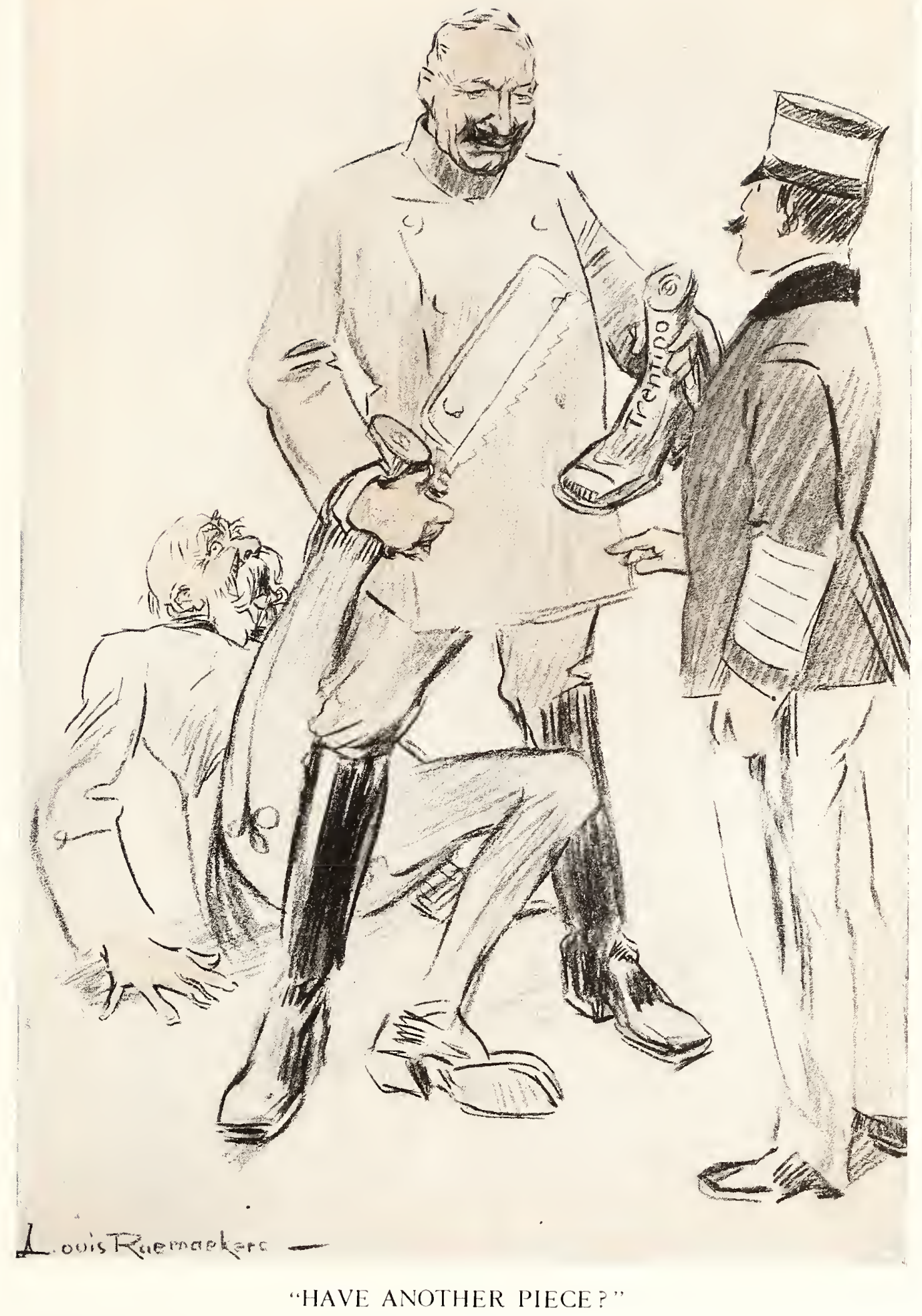




\section{Easter, 1915}

CVER since with the beginning of Christendom a new soul entered the body of exhausted Europe, it is true to say that we have not only had a certain idea but been haunted by it, as by a ghost. It is the idea crystallized in legends like those of St. Christopher and St. Martin. But it is equally apparent in the most modern ethics and eloquence, as, for instance, when a French atheist orator urged the reconsideration of a criminal case by pointing at the pictured Crucifixion which hangs in a French Law Court and saying: "Voilà la chose jugée." It is the idea when that oppressing the lowest we may actually be oppressing the highest, and that not even impersonally, but personally. We may be, as it were, the victims of a divine masquerade; and discover that the greatest of kings can travel incognito.

Such a picture, therefore, as the cartoonist has drawn here can be found in all ages of Christian history as a comment on contemporary oppression. But while the central figure remains always the same, the types of the tyrant and the mocker hold our temporary attention; for they are sketched from life and with a living exactitude. Upon one of them especially it would be easy to say a great deal: the grinning Prussian youth with the spectacles and the monkey face, who is using a Prussian helmet instead of the crown of thorns.

Such a scientific gutter-snipe is the real and visible fruit of organized German education; he is a much truer type than any gory and hairy IIun. In the face of that young atheist there is everything that can come from the congestion of the pagan with the parvenu; all the knowingness that is the cessation of knowledge; and that something which always accompanies real atheism-arrested development.

\section{G. K. CHESTERTON.}




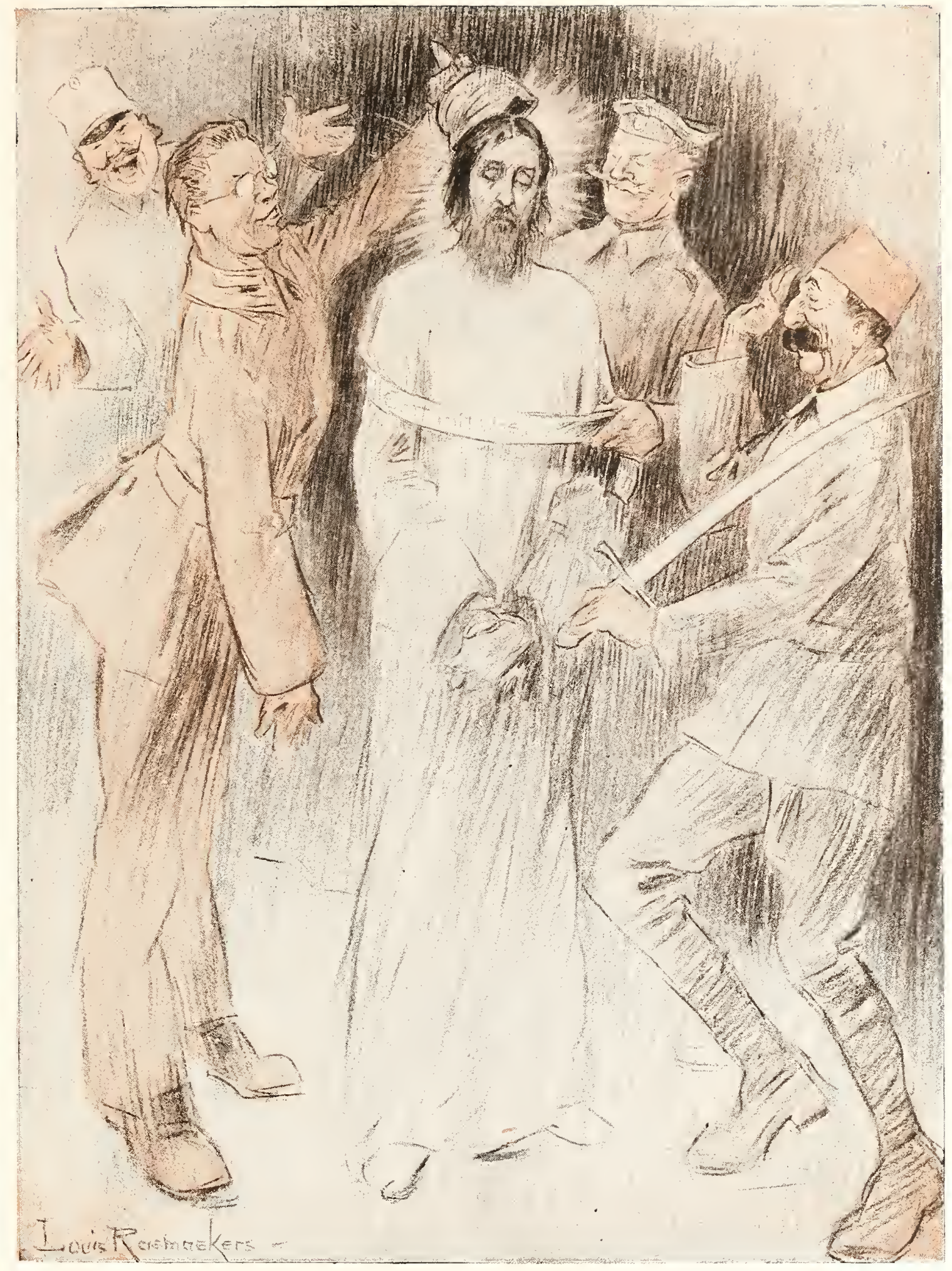

EASTER, 19I5

"And they bowed the knee before Him." 


\section{Pan Germanicus as Peace Maker}

TMAGINE the feelings of the hindlegs of a stage elephant on being told that the performance is to be a continuous one and you will have some inkling of the dismay of the Kaiser and his henchman, concealed in the plumage of the War Eagle and the Dove of Peace respectively. The one bird is as useless as the other in bringing the war to the end desired in Berlin. The stage eagle is daily losing its plumage, and is rapidly becoming but a moulty apology for the king of birds. As for the dove, it has been used so often, with constantly changing olive branch in its beak, that it now makes its appearance shamefacedly and absolutely without heart.

Imperial eagle mask with half-mad military quasi-deity inside and dove of peace, on the German model, with calculating miscalculating statesman, you rang the curtain up, you cannot ring it down, either to the music of the Hymn of Hate or the Te Deum for peace - the eagle can no longer look boldly straight into the sun, looking for his place in it; the dove has taken permanent quarters in the German ark as it whirls round and round in the whirlpool of impotent effort, ever drawing nearer to the final crash. When the Dove of Peace does come, it will be a real bird of good omen, not a German reserve officer masquerading as one.

ALFRED STEAD. 


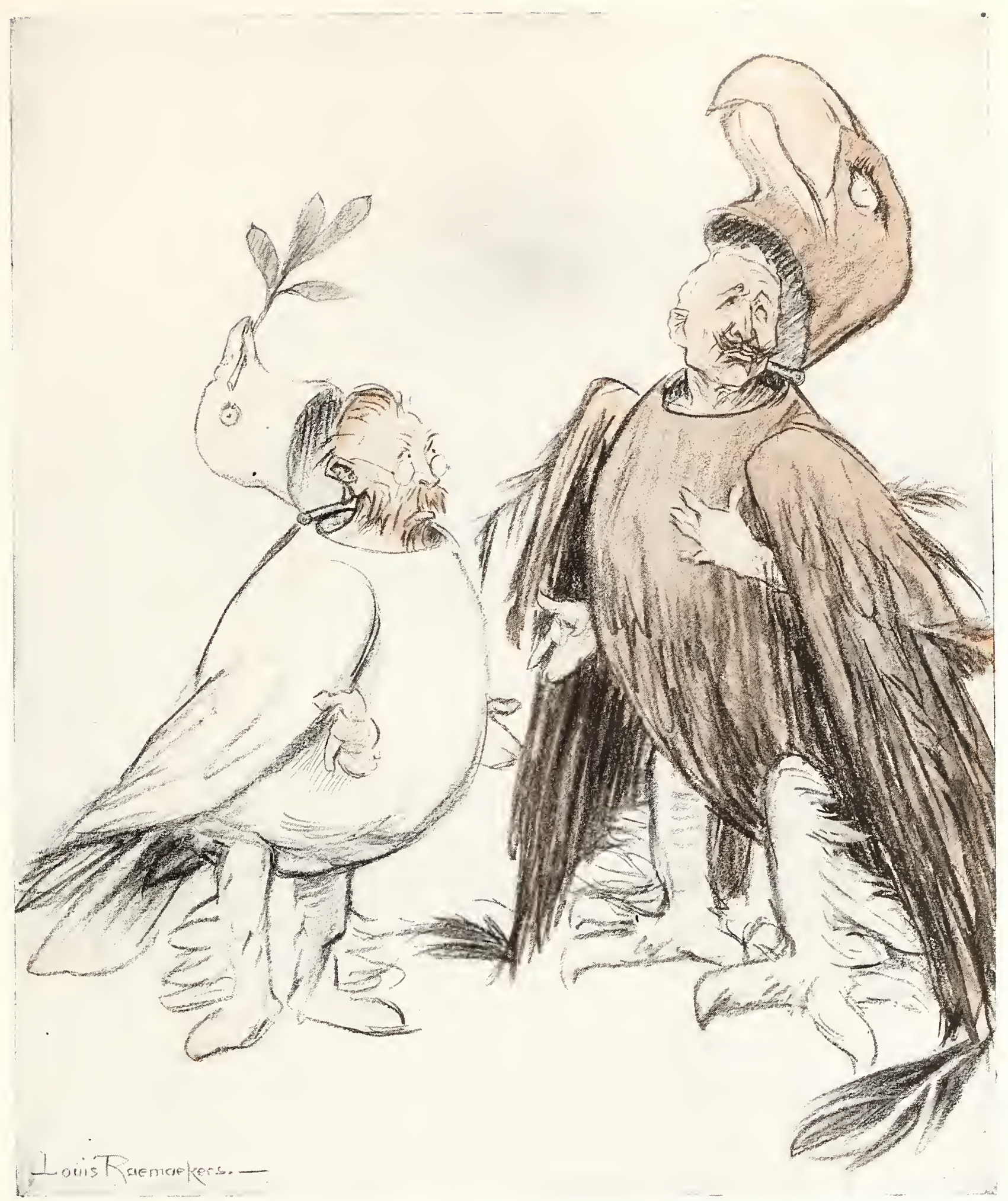

PAN GERMANICUS AS PEACE MAKER

The Dove: "They say they do not want peace, as they have time enough." THE EAGLE: "Alas! That is just what we haven't got." 


\section{Gott Mit Uns}

$\mathrm{T}$

HIS picture is a perfectly accurate symbolic study of the German Empire. Therefore, naturally, it is one of the most dreadful that were ever drawn. In all the gruesome "Dances of Death" in which the fifteenth century took so grim a pleasure, no artist ever conceived the horrible idea of a fat skeleton. But we have not only conceived the thought, we have seen the thing- "a terror in the sunshine." We know that chest, puffed up with a wind of pride, and that stomach heavy with slaughter and rich living; and above them the Death's Head. We have seen it. We have felt its foul breath. Its name is Prussia.

Look at a portrait of Frederick the Great, the "onlie true begetter" of this abortion. It oddly suggests what Raemackers has set down here: the face a skull, the staring eyes those of a lost soul. But the skeleton has grown fat since Frederick's day-fat on the blood and plunder of nations. Only there is no living flesh on its bones, nothing of humanity about it.

"Can these dry bones live?" was the question asked of the prophet. It might have been asked of Frederick: "Can this nation live, created of your foul witchcraft, without honour, without charity, without human brotherhood or fellowship, without all that which is the flesh and blood of mankind?" The answer must have been that it could live, though with a life coming from below and essentially infernal. It could live-for a time. It could even have great power because its time was short.

But now it has waxed fat-and kicked. And its end is near.

CECIL CHESTERTON. 


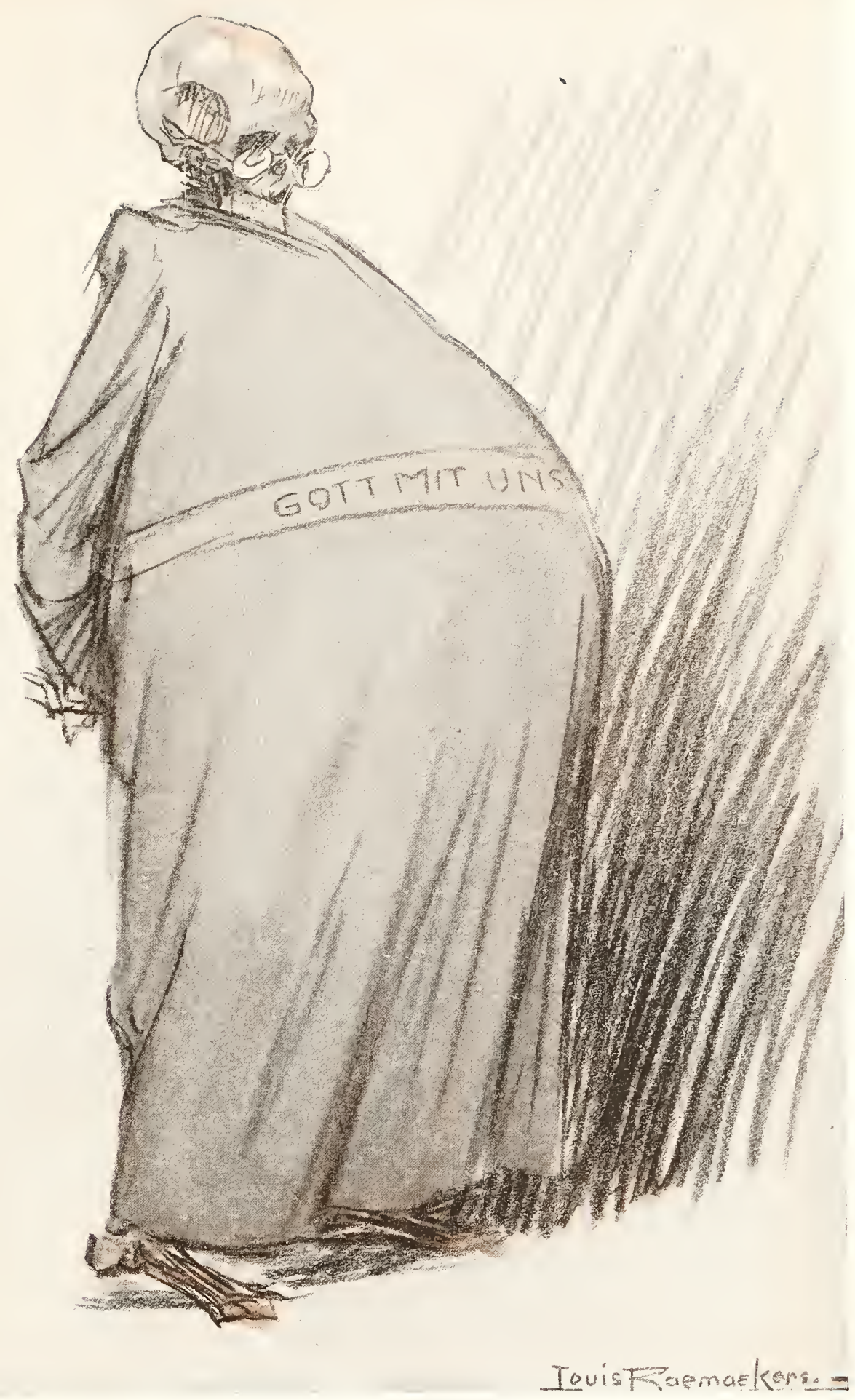

IT'S FATTENING WORK 


\section{Our Lady of Antwerp}

$\mathrm{H}$

ERE I and sorrows sit. This is my throne, bid Kings come worship it." Such seems to be an appropriate legend for

Raemackers' beautiful triptych which he has entitled "Our Lady of Antwerp." Full of compassion and sympathy for all the sufferings of her people, she sits with the Cathedral outlined behind her, her heart pierced with many agonies. On the left is one of the many widows who have lost their all in this war. On the right is a soldier stricken to death, who has done his utmost service for his country and brings the record of his gallantry to the feet of Our Lady of Antwerp.

Antwerp, as we know, was at the height of its prosperity in the sixteenth century. We have been told that no fewer than five hundred ships used to enter her port in the course of a day, while more than two thousand could be seen lying in her harbour at one time. Her people numbered as many as one million, her fairs attracted merchants from all parts of Europe, and at least five hundred million guilders were put into circulation every year. We know what followed. Its very prosperity proved a bait to the conqueror. In 1576 the city was captured by the Spaniards, who pillaged it for three days. Nine years later the Duke of Parma conquered it, and about the time when Queen Elizabeth was resisting the might of Spain Antwerp's glory had departed and its trade was ruined. At the close of the Napoleonic wars the city was handed over to the Belgians.

A place of many memories, whose geographical position was well calculated to arouse the cupidity of the Germans, was bound to be gallantly defended by the little nation to which it now belonged. Whether earlier help by the British might or might not have altered the course of history we cannot tell. Perhaps it was not soon enough realized how important it was to keep the Hun invader from the sacred soil. At all events we do not look back on the British Expedition in aid of Antwerp in 1914 with any satisfaction, because the assistance rendered was either not ample enough or else it was belated, or both. So that Our Lady of Antwerp has still to bewail the ruthless tyranny of Berlin, though perhaps she looks forward to the time when, once more in possession of her own cities, Belgium may enter upon a new course of prosperity. We are pledged to restore Belgium, doubly and trebly pledged, by the words of the Prime Minister, and justice will not be done until the great act of liberation is accomplished.

W. L. COURTNEY. 


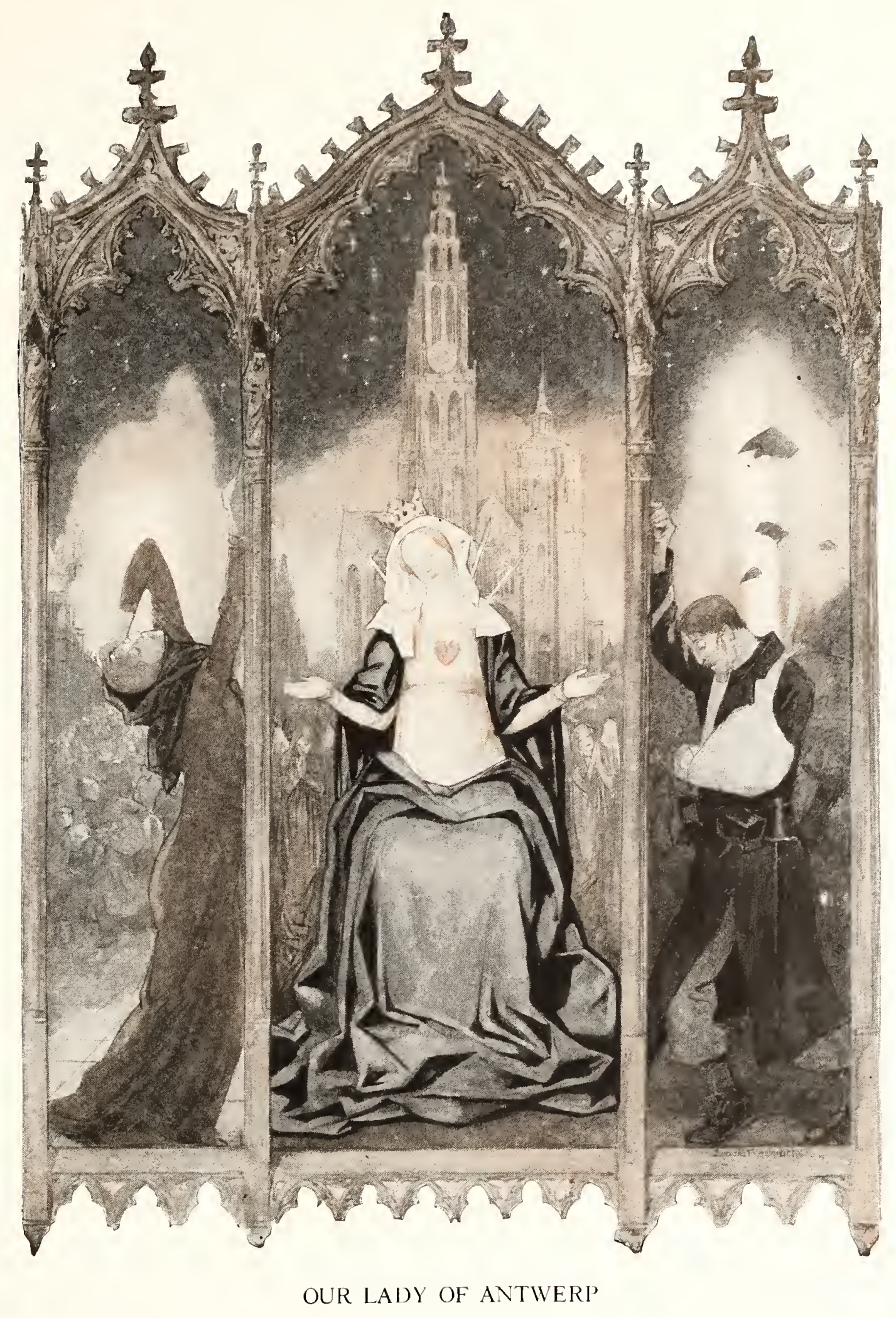




\section{Deportation}

$\mathrm{N}$

OTHING, when one analyzes it, could be imagined more thoroughly characteristic of Prussia than the particular stroke of

policy by which a large proportion of the male population of Belgium - as also in a somewhat lesser degree of Northern Francewas separated from its family ties and hurried away into exile in Germany, there to be compelled to work for the profit of enemies.

It had all the marks of Prussianism.

Firstly, it was a violation of the civilized and Christian tradition of European arms. By the rules of such warfare the non-combatant was spared, wherever possible; not only his life but his property and liberty were secure so long as he did not abuse his position.

Secondly, it was an affront to decent human sentiment quite apart from technical rules; the man, guilty of no offence save that of belonging to a country which Prussia had invaded without justice and ravaged without mercy, was torn from his family, who were left to the mercy of their opponents. We all know what that mercy was like.

Thirdly, it was an insult to the human soul, for the unfortunate victims were not only to be exiled from their country, but to be driven by force and terror to serve against it.

Fourthly, and finally, like all the worst Prussian crimes, it was a stupid blunder. Prussia has paid already a very high price for any advantage she may have gained from the mutinous and unwilling labour of these men, and for the swelling of her official return for the edification of her own people and of neutrals by the inclusion of "prisoners of war" of this description. To-day, when she knows not where to turn for men, she is obliged to keep a huge garrison tied up in Belgium to guard her line of retreat. And when the retreat itself comes, the price will rise even higher, and the nemesis will be both just and terrible.

CECIL CHESTERTON. 


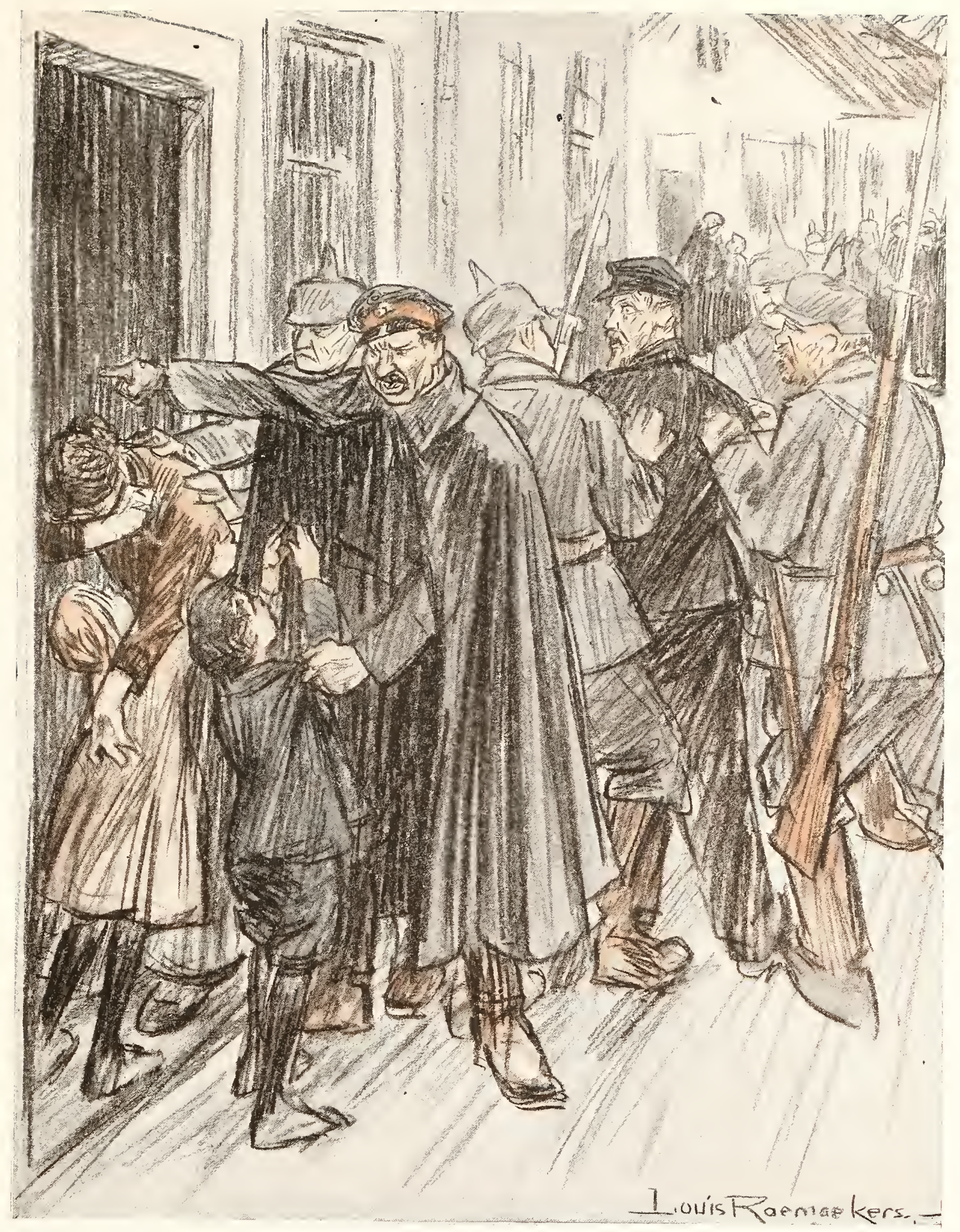

HUSBANDS AND FATHERS

Belgian workmen were forcibly deported to Germany. 


\section{The German Band}

THE German Band, as we know it in this country, has never been noted for harmonious music. Blatancy, stridency, false notes, and persistency after the coppers, have been its chief characteristics.

And the same things prevail when it is at home.

Never since the world began has there been such a campaign of barefaced humbug and lying as that organized by William, Hindenburg, Hollweg and Co. for the deceiving and fleecing of the much-tried countries temporarily under their sway.

But the money had to be got in by hook or by crook, and by hook and by crook and in every nefarious way they have milked their unfortunate peoples dry.

But there is another side to all this. In time, the veil of lies and false intelligence of victories in the North Sea, and at Verdun, and, indeed, wherever Germany has fought and failed, will be rent by the spear of Truth.

Then will come the débâcle. And then, unless every scrap of grit and backbone has been Prussianized out of the Teuton, the revulsion of feeling will sweep the oppressors out of existence; and Germany, released from the strangle-hold, may rise once more to take the place among the civilized nations of the world which, by her foul doings of the last two years, she has deliberately forfeited.

JOHN OXENHAM. 


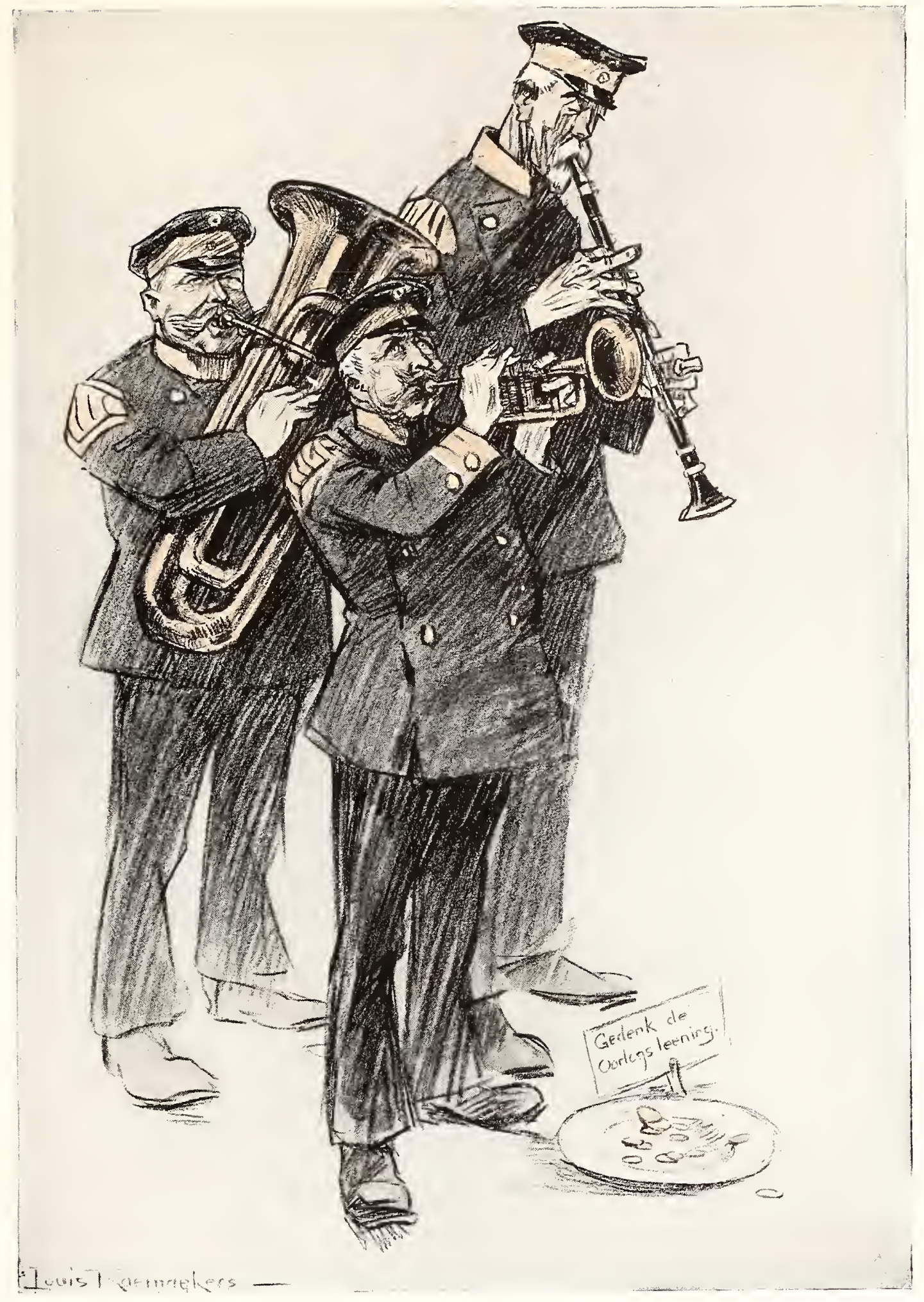

WAR LOAN MUSIC

"Was blazen die Trompeten Moneten heraus?" 


\section{Arcades Ambo}

OOKING at this cartoon one can understand why Raemaekers is not persona grata in the Happy Fatherland. With half a dozen touches he has changed Satan from the magnificent Prince of Evil whom Gustave Doré portrayed into a-Hun. Henceforth we shall envisage Satan as a Hun, talking the obscene tonguenow almost the universal language in Hades-and hailed by rightthinking Huns as the All Highest War Lord. Willy senior must be jealous.

With the learned Professor, the cartoonist not only produces a composite portrait of all the Herren Professoren, but also drives home the point of his amazing pencil into what is perhaps the most instructive lesson of this monstrous war - the perversion to evil uses of powers originally designed, nourished, and expanded to benefit mankind. When the Furor Teutonicus has finally expended itself, we do not envy the feelings of the illustrious chemists who perfected poison gas and liquid fire! Will they, when their hour comes, find it easy to obey the poet's injunction, and, wrapping the mantle of their past about them, "lie down to pleasant dreams?"

We are assured that these professors have not exhausted their powers of frightfulness. It may be so. This is certain: Such frightfulness will ultimately exhaust them. With this reflection, we may leave them, grist to be ground by the mills of God.

HORACE ANNESLEY VACHELL. 


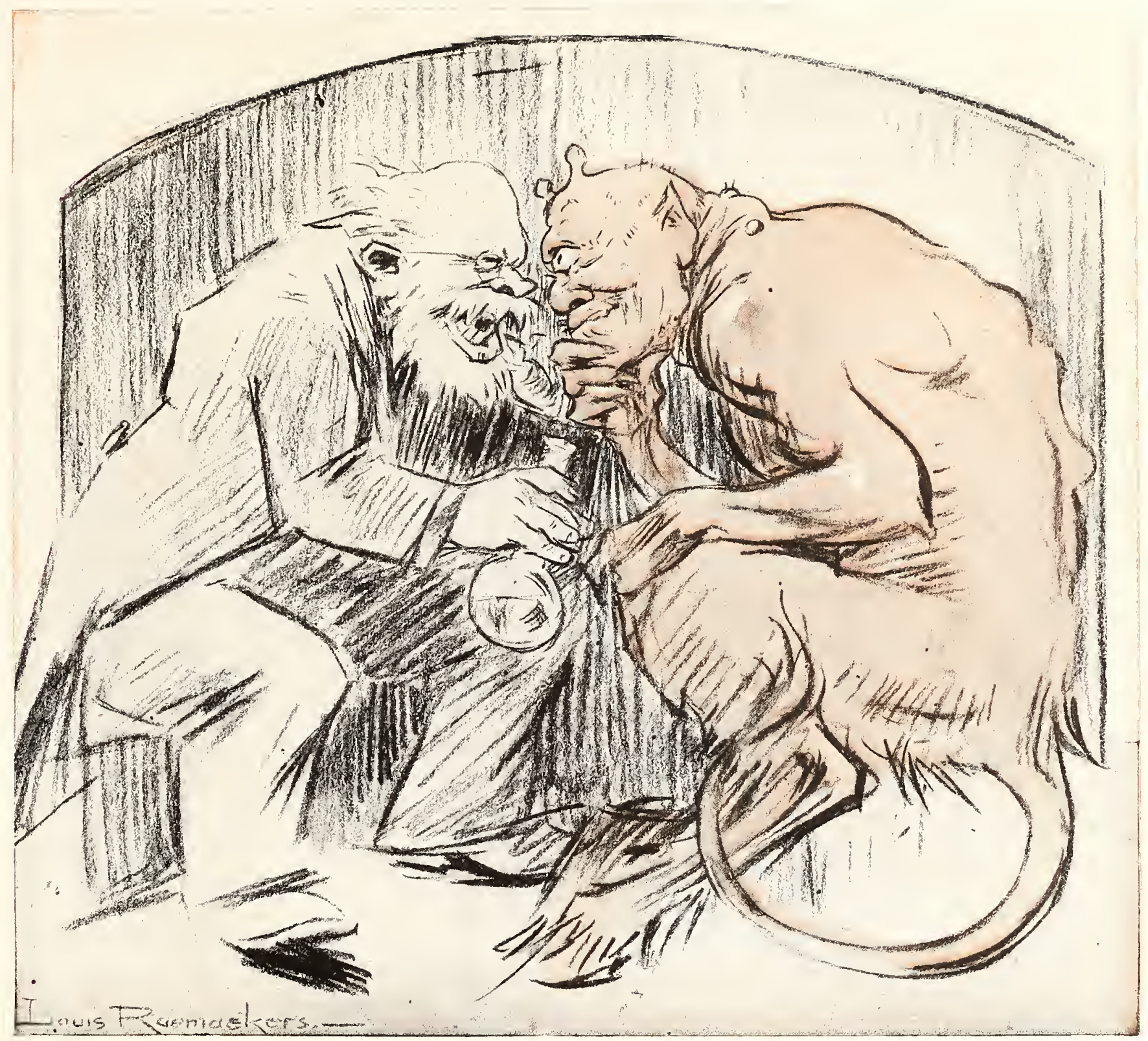

ARCADES AMBO

The Professor: "I have discovered a new mixture which will blind them in half an hour."

SATAN: "You are in very truth my master." 


\section{"Is It You, Mother?"}

S INCE the opening of hostilities in the present war the Scottish regiments have given repeated proofs of a valour which adds new lustre to the great traditions of Scottish soldiership. Through all the early operations - on the retreat from Mons and at the battles of the Marne and the Aisne-the Royal Scots Guards, the Scots Greys, the Gordon, the Seaforth and the Argyll and Sutherland Highlanders, the King's Own Scottish Borderers gained many fresh laurels by their heroism and undaunted spirit. The London Scottish Territorials, too, have shown a prowess as signal as that of the Scots of the Regular Army; while the mettle of men of Scottish descent has made glorious contribution in France and elsewhere to the fine records of the Overseas armies.

It is the inevitable corollary that death should levy a heavy toll on Scottish soldiers in the field. Thousands of kilted youth have suffered the fate which Raemaekers depicts in the accompanying cartoon. It is not, of course, only the young Scot whose thought turns in the moment of death to the hearth of his home with vivid memories of his mother. But the word "home" and all that the word connotes often makes a more urgent appeal to the Scot abroad than to the man of another nationality. There is significance in the fact that, far as the Scots are wont to wander over the world's surface, they should, under every sky and in every turning fortune, treasure as a national anthem the song which has the refrain:-

"For it's hame, an' it's hame, fain wad I be, O! it's hame, hame, hame, to my ain countrie!"

The German soldier in this war would seem to have lost well nigh all touch of humanity. Yet the draughtsman here suggests that even the German soldier on occasion yields to the pathos of the young Scot's death-cry for home and mother. There is grim irony in the dying man's blurred vision which mistakes the hand of his mortal foe for that of his mother.

Of such trying scenes is the drama of war composed.

SIDNEY LEE. 


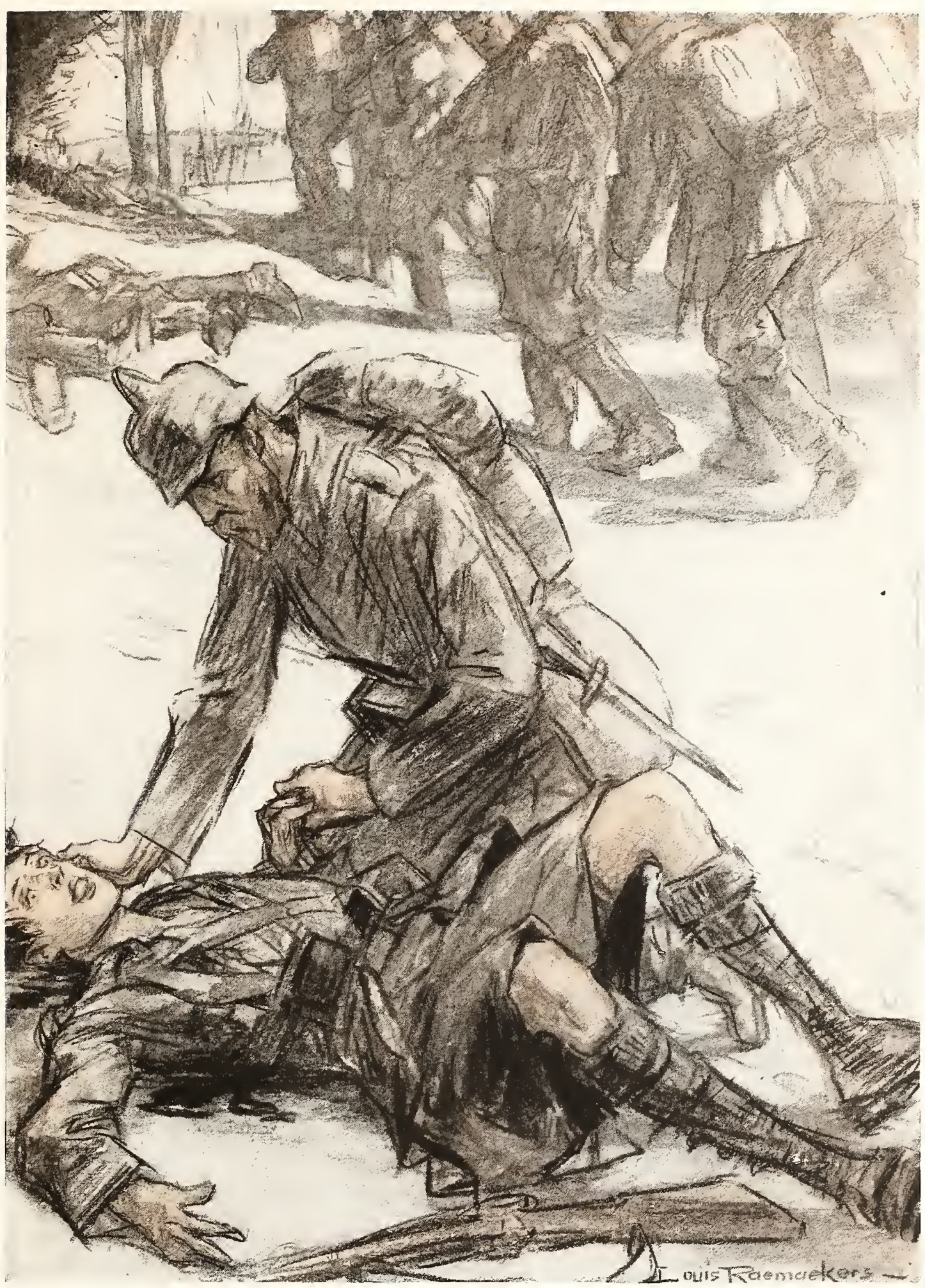

"IS IT YOU, MOTHER?' 


\section{The Fate of Flemish Art at the Hands of Kultur}

T T WILL not be possible to estimate the injury suffered by the monuments of art wherein Belgium was so rich till the war is ended and the ruins examined. Much of the irreparable loss we know, as in the cases of Louvain and Ypres. In general we may fairly conjecture that whatever is portable behind the German lines is stolen, or will be, and the rest destroyed. What is portable is stolen for its cash value, just as are money, furniture, clothes, and watches. So much of respect for works of art we may expect from the Prussians - the measure of respect for the cash shewn by the Prussian general at Termonde who robbed a helpless civilian of the 5,000 francs he had drawn to pay his workmen's wages, and then called earth and heaven to witness his exalted virtue in not also murdering his victim. But what cannot be carried - a cathedral, a monument, an ancient window - that is destroyed with an apish zest. Even a picture in time or place, inconvenient for removal, that also will be defiled, slashed to rags, burnt. And indeed why not? For the best use of a work of art as understood among the Prussian pundits is to make it the peg whereon to hang some ridiculous breach of statistics, some monstrous disquisition of bedevilled theory; and for such purposes a work no longer existing so as good as any-even better.

And so the marvels of the centuries go up in dust and flames, and the memorials of Memling and Matsijs, Van Eyck, and Rubens are treated as the masters' own bodies would have been treated, had fate delayed their time till the coming of the Boche.

ARTHUR MORRISON. 


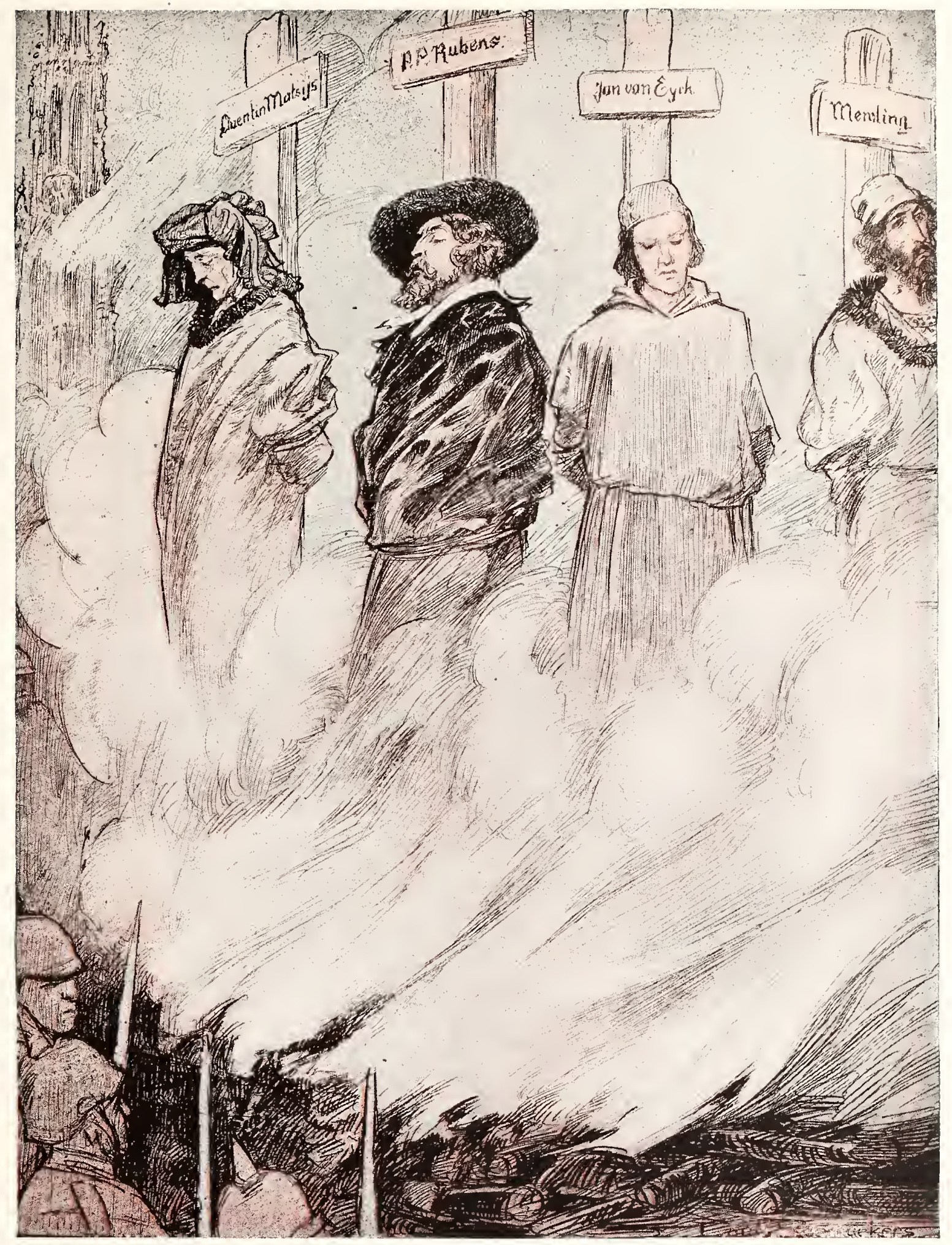

THE FATE OF FLEMISH ART AT THE HANDS OF KULTUR 


\section{The Graves of All His Hopes}

T OOK at the map," says the German Chancellor. Look at the map, and mark with a cross every German disappointment and you will have a history of the war more illuminating than many books on the subject. The Marne, Ypres, South Africa, West Africa, Egypt, Bagdad, India, Tripoli, Verdun. Look at the map indeed. The map of the world that Germany set out to conquer. Consider the vapouring and vainglory that marked each of these "successes" in political or military trickery and the fact that of the military crosses each upbears above a mountain of losses the refrain of the old German song Verdorben--Gestorben-Ruined-Dead.

It is a wonderful map to consider, this map of the world in 1916 . A wonderful map to be studied by the mothers of the Fatherland who have suckled their children to manure the crops of the future, to feed the crematoriums and blast furnaces of Belgium, to fill the mad houses, blind asylums, and homes for incurables, when the frosts of Russia and the guns of the Allies have done with them.

And every cross marks the grave of a hope.

\section{Paris}

Regrets eternels.

That wonderful inscription was the first to be cut. Galliene was the mason. Verdun was the last and will not be the least. But, whatever may come to be written on stone, on the heart of the mourner when he comes to die only one inscription will be found: "Calais." If he has a heart large enough to have even these six letters.

H. DE VERE STACPOOLE. 


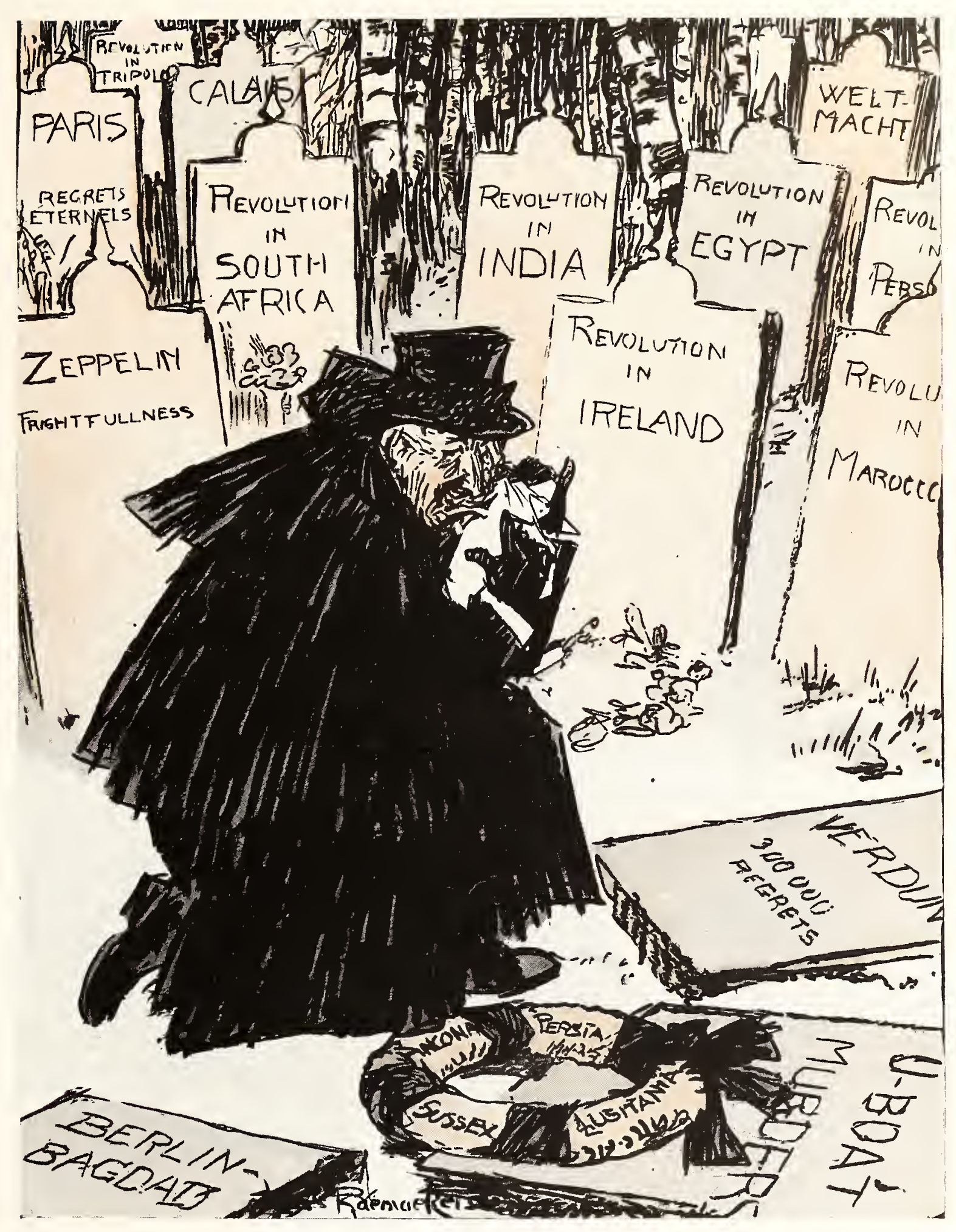

THE GRAVES OF ALL HIS HOPES 


\section{"My Sixth Son Is Now Lying Here-Where Are Yours?"}

HERE is a picture in Brussels that the Kaiser ought to study on one of his visits to the Belgian capital. It is Wertz's picture of Napoleon in Hades.

Wert $z$ was a madman, he knew something of the horrors of war, but he knew, also, something of the grandeur and nobility of Napoleon.

Napoleon is surrounded by women holding up the mutilated remains of sons, lovers, and fathers, and still he remains Napoleon, the child of Destiny, the Inscrutable, the Calm, and, if one may say so, the Gentleman.

Women knew, at least, that their dead had fallen before the armies or at the will of a great man in those Napoleonic days; there was something of Fate in the business.

But to-day the widow or the mourning mother, whilst knowing that her son or her husband has fallen in defending Humanity from the Beast can find no quarter in their hearts for the form or the shape of manhood that stands, in the words of Swinburne:

"Curse consecrated, crowned with crime and flame!"

No taunt could be too bitter for their lips and none more bitter than the words of Raemaekers:

"My sons are lying here-where are yours?"

H. DE VERE STACPOOLE. 


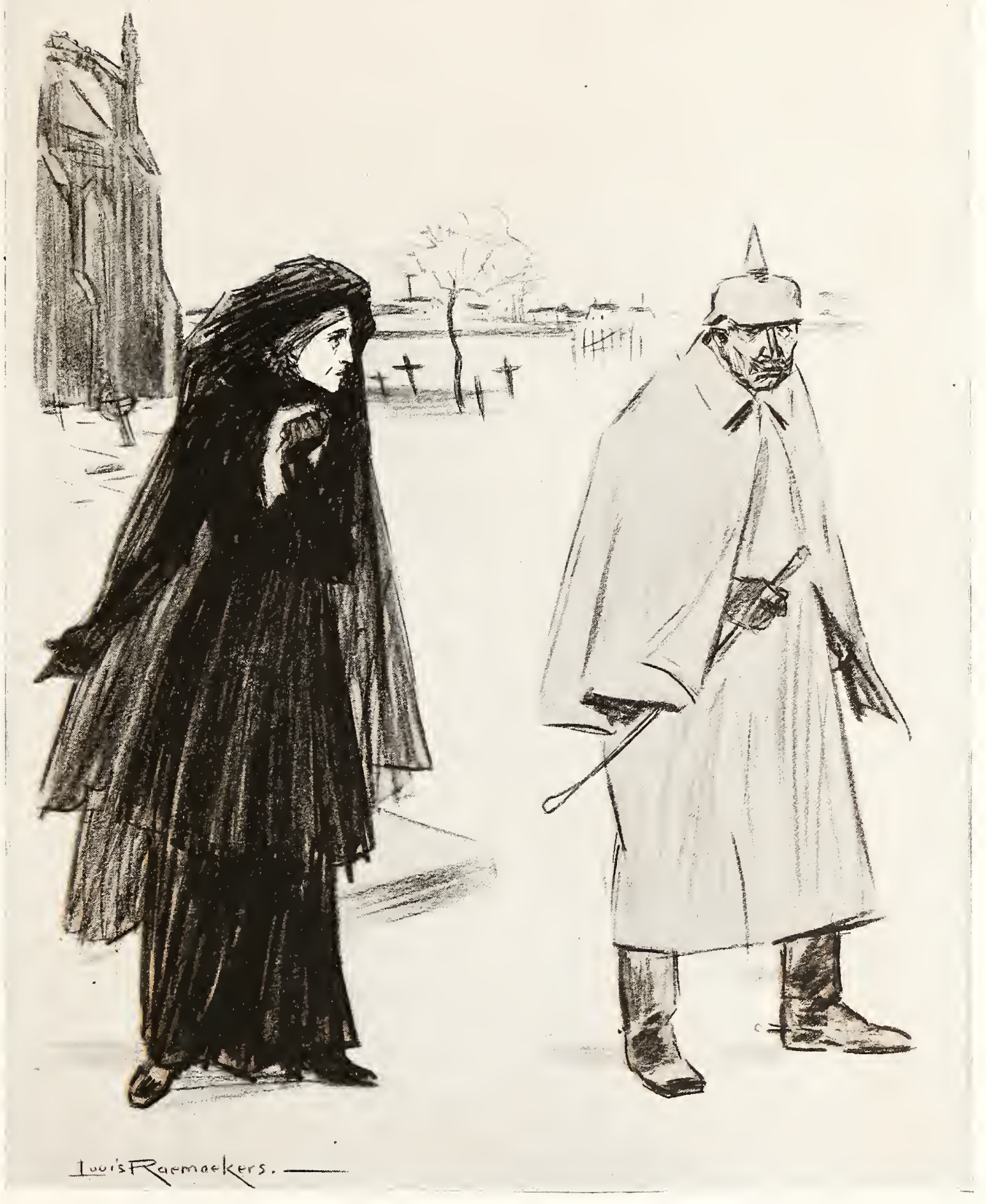

"MY SIXTH SON IS NOW LYING HERE-WHERE ARE YOURS?" 


\section{Bunkered}

$\mathrm{T}$

HE Crown Prince is in a very awkward predicament. He has driven his ball into a deep sand-pit from which a very clever professional golfer might perhaps extricate himself by a powerful stroke with a niblick. But young William is not a professional, and indeed knows nothing about the game. So he takes his driver and his other wooden clubs, and smashes them all, with much bad language, while he whacks at the ball, which only buries itself deeper in the sand. He is pondering what to do next. There is, however, only one thing to do. He must take up his ball and lose the hole. The real players on his side must be disgusted at being saddled with such a partner. But what is to be done when a fool is born a war-lord by right of primogeniture? In a few years, in the course of nature, this fortunate youth will be the Supreme War-Lord himself; it will be his business to "stand in shining armour" by some luckless ally who has been selected to pick a quarrel for Germany's benefit, and to shake a "mailed fist" in the face of a trembling world. That will be a spectacle for gods and men. But perhaps something will happen instead.

IV. R. INGE. 


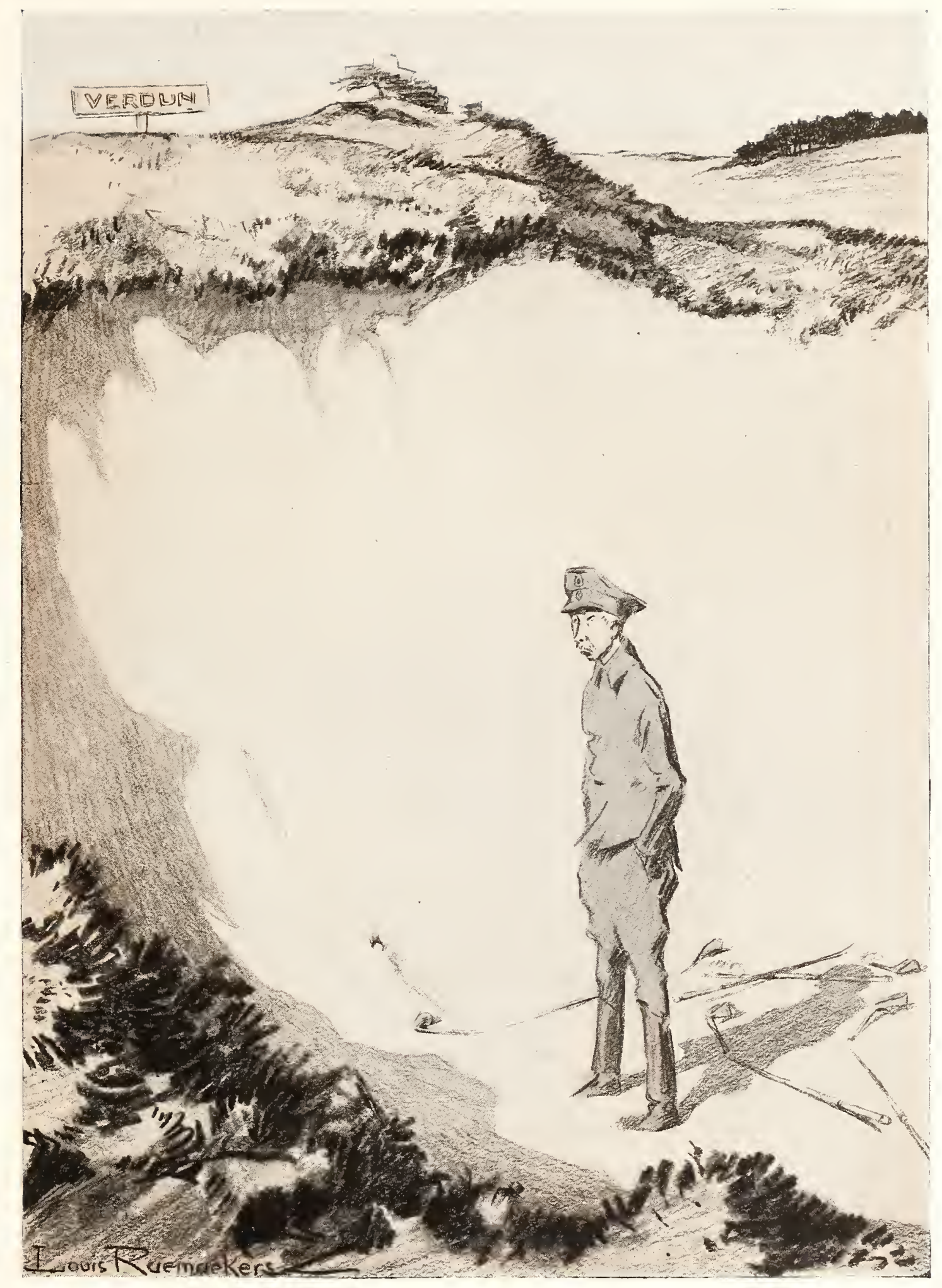

BUNKERED 


\section{Gott Strafe Verdun}

$A^{N}$

IMPARTIAL military verdict on the German strategy and tactics at Verdun has not yet been delivered. After the failure of the Allies to break through last year, the German higher command issued a paper, which has been printed in American newspapers, advocating "nibbling" tactics, instead of attempts to carry a strongly fortified line by a coup de main. The Germans have buoyed up their hopes by assuring each other that their troops have been making a slow but methodical progress toward the "fortress," according to program. But even if we grant that the disproportion in casualties is probably not so great as some of our critics have supposed, it is difficult to believe that the enemy was prepared for such resistance as he has met with. To all appearance, the Germans expected to break through in a few days, and hoped that this success would rehabilitate the credit of the paltry young prince whom we here see entangled in barbed wire, his uniform in rags, and despair depicted on his haggard face. Another confessed failure would finish the career of the Crown Prince; and yet there are limits to the endurance of any troops, and these limits have now been reached. There is nothing left to young William but useless imprecations. He swaggered into this war, for which he is partly responsible, expecting to win the reputation of a general; he will sneak out of it with the reputation of a burglar.

W. R. INGE. 


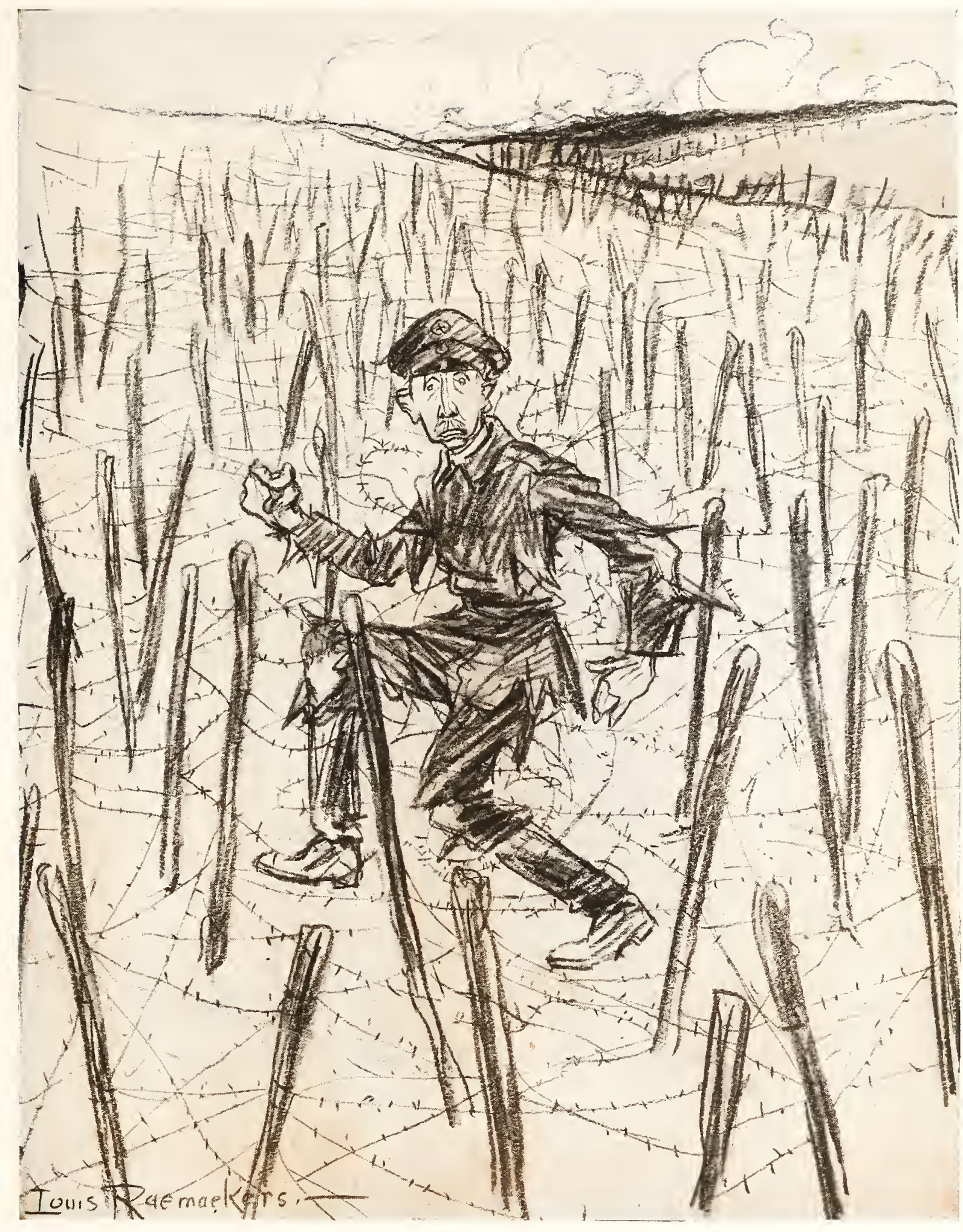

GOTT STRAFE VERDUN

"If only I knew whether it is less dangerous to advance or to retire." 


\section{The Last Throw}

$\mathrm{T}$

HE first throw, of course, was that great rush which was stayed at the Marne by the Genius of Joffre; then there was the throw of the great attack on Russia, that which laid waste Serbia, and that which would have thrust men down from the Alps on to the Italian plain. In each of these Raemaekers' symbolism is applicable, for in each case death threw higher than either Germany or Austria could afford.

But in none is the symbolism so terribly fitting as in this case of Verdun, where the fighting men went forward in waves and died in waves-here death threw higher in every attack than Germany could throw, and to such heights was the slaughter pushed that it was, in truth, the last throw of which these war-makers were capable. It is significant, now that Germany can no longer afford such reckless sacrifices as were made before Verdun, that the German press contains allusions to heavy sacrifices on the part of the Allies, and tries to point to folly in allied policy. Surely, in the matter of sacrifice of life, no nation is so well qualified to speak from experience as Germany.

There is clumsy anxiety expressed in every line of the figure that holds the dice box, and in every line of the figure in the background is nervous fear for the result of the throw-fear that is fully justified. But Death, master of the game, waits complacently to mark the score, knowing that these two gamblers are the losers--and that the loser pays.

E. CHARLES VIVIAN. 


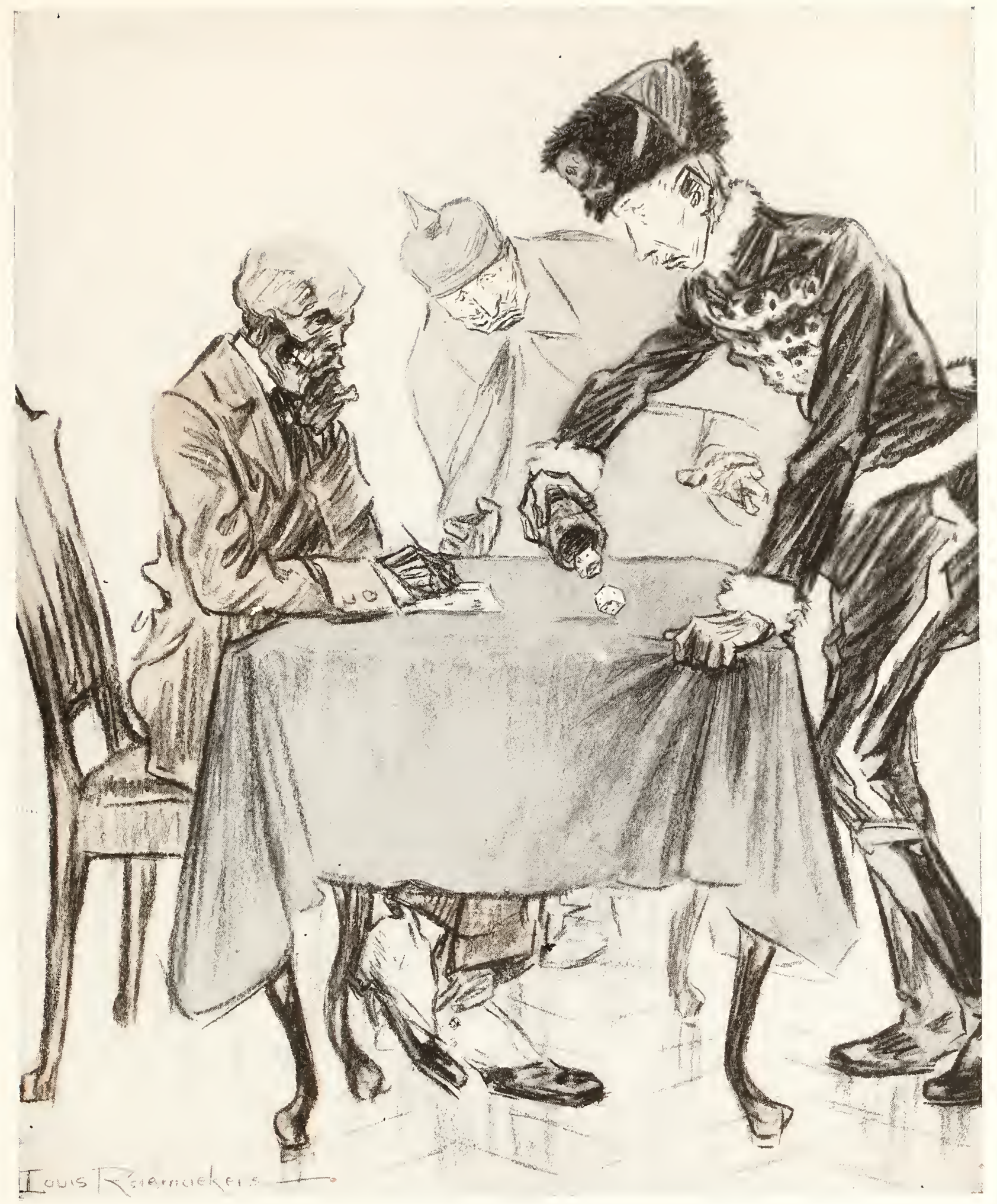

THE LAST THROW 


\section{The Zeppelin Bag}

$\mathrm{H}$

ERE the artist has depicted the Kaiser in one of his favourite rôles, that of a sportsman. In pre-war times it was one of "The All Highest's" chief ambitions to be taken for an English sportsman! We believe there were people in those now seemingly remote days who took him at his own valuation in this regard. Our picture papers were full of photographs of him shooting at this or that nobleman's estate, lunching after the morning's battue, in the act of shooting, inspecting the day's "bag," etc.; and other pictures were reproduced from the German papers from time to time of a similar character showing him as a sportsman in his native land.

There is still, thank God, something clean about British sport and sportsmen of which the Kaiser never caught the inwardness and spirit. It has come out on the battlefields to-day as it has on those of past generations. It has taught the British soldier to fight clean, and even chivalrously though the foe may be a past master in "knavish tricks," and steeped in unspeakable methods of cruelty in warfare.

How thin the veneer of a sportsmanship was upon the Kaiser, which is after all but symbolic of the higher and sterner virtues, all the world has had a chance of judging. And in this remarkable and arresting drawing the genius of the artist has taken and used a sporting incident with telling and even horrifying effect.

In the old days it was pheasants, partridges, grouse, hares, rabbits, and other feathered game, with the nobler stags and boars that formed "the Butcher of Potsdam's "bag." To-day he has his battues by proxy on sea, land, and from the air. Thousands of victims, as innocent as the feathered folk he slaughtered of yore; and women and little children form the chicf items of the bag; and especially is this true of the "fruit of the Zeppelin raids."

He counts the bag and rewards the slayers of the innocent as he doubtless did the beaters, huntsmen, and keepers of the estates over which he formerly shot. It has been his ambition to make Europe one vast Kaiserdom estate. But the sands are running out, and each "bag," whether by Zeppelin or submarine, serves but to stiffen the backs of the Allies and horrify neutral nations. Some day the accumulated horrors of the Kaiser's ideas of sportsmanship will have taught the latter the lesson that Kaiserdom with Europe as a Kaiser estate means the death of liberty, the extinction of the smaller nations, and the setting up of a despotism as cruel as that of Attila and his Huns- the self-accepted and preached examples of William II of Germany.

CLIVE HOLLAND. 


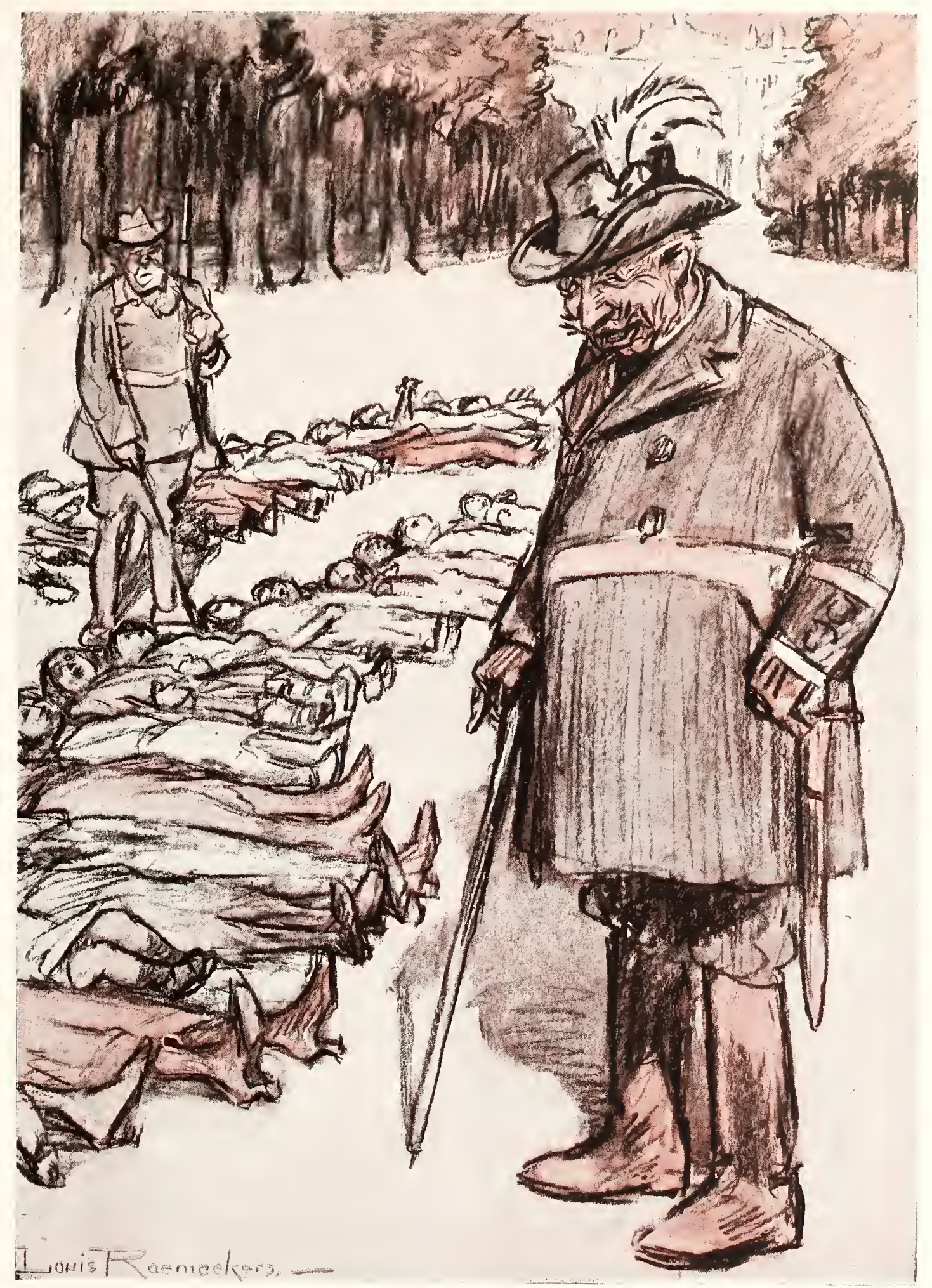

THE ZEPPELIN BAG 


\section{"Come in, Michael, I Have Had a Long Sleep"}

Y ES-a long and rejuvenating sleep! The expression upon John's face indicates an amazing determination and alertness. It is told of certain remarkable men-De Lesseps amongst the number-that they had the faculty of sleeping for several days and nights and then remaining wide awake and at full tension for an equally long period of time. We may confidently predict that John has this faculty. He is not likely to slumber again till his work is done, and done thoroughly. Michael's expression, I regret to note, is not quite so pleasing as John's. It gives "furiously to think," as our gallant and beautiful France puts it, that when Michael climbs through the window of the Happy Fatherland, he may, perchance, inspire terror in the heart of the Hun, who doubtless expects that his enemies, if they do invade the sacred soil, will display those Christian qualities of Mercy and Forbearance which have been so conspicuous, by their absence, in the treatment of unfortunate prisoners upon whom they inflicted the extreme rigour of "Kultur."

Our cartoonist, it will be noticed, has placed sledge hammers in the hands of both John and Michael, rather primitive weapons, but most admirably adapted for "crushing." And nothing short of crushing will satisfy the Allies, despite the futile wiles and whines of Messrs. Trevelyan, Ponsonby, Morel, and Macdonald. Crushed they will and must be to fine powder. The hammer strokes are falling now with a persistence and force which, at long last, reverberates in the cafés and beer gardens of Munich and Berlin. The Teuton tonguea hideous concatenation of noise at its best-must be almost inarticulate to-day in its guttural chokings and splutterings. "Frightfulness" is coming home to roost.

With all our hearts we hold out the glad hand to Michael.

Come in, and stay in-bless you!

HORACE ANNESLEY VACHELL. 


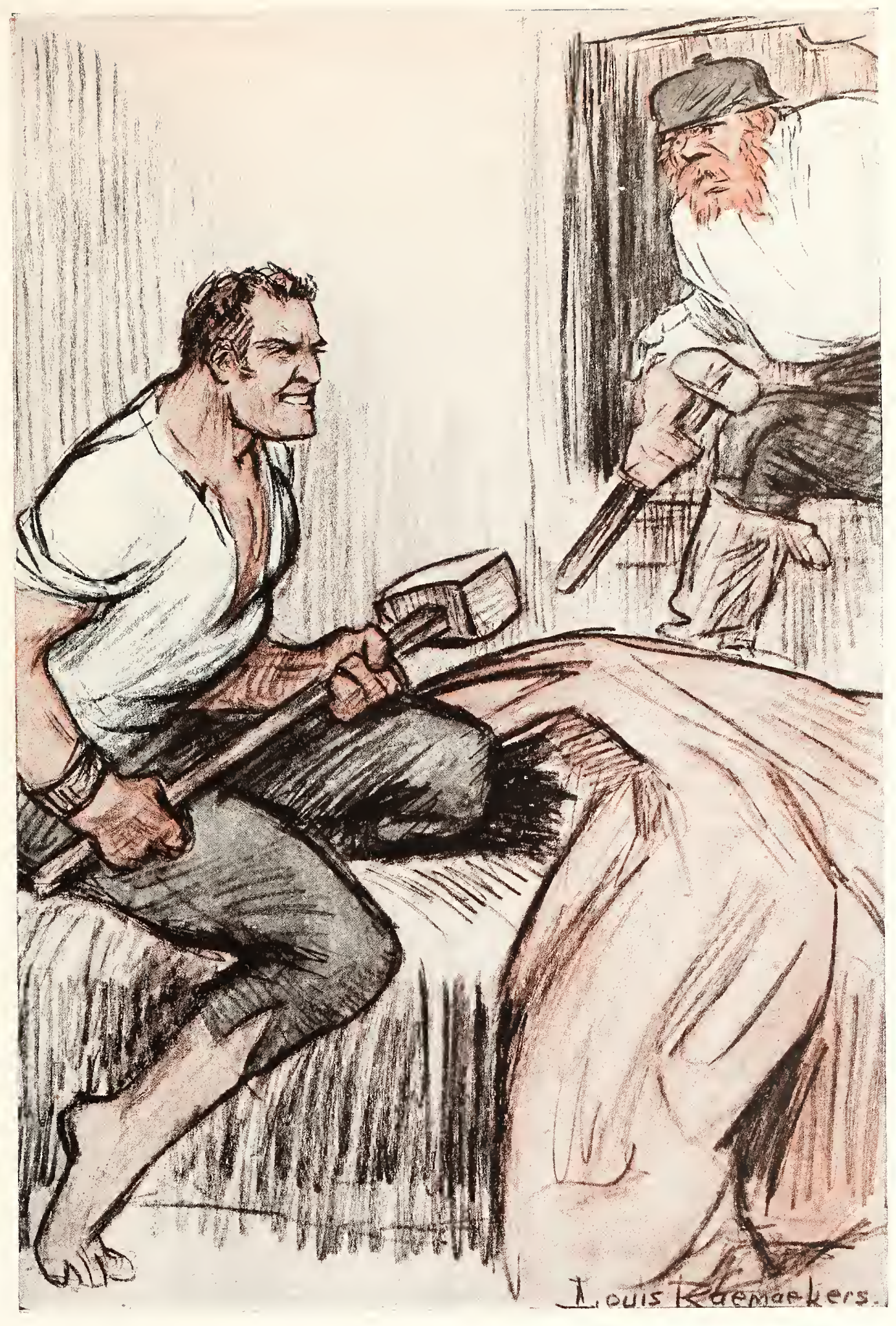

"COME IN, MICHAEL, I THINK I'M AWAKE NOW" 


\title{
Five on a Bench
}

\begin{abstract}
$A^{\text {H. }}$ L visions and poems of justice have been fuil of the refrain of deposuit potentes de sede; but the bracing reality of such a revolution is lost by certain effects of antiquity, by the mists which make the past somewhat monochrome, and by the exalted equality of death. To say that Belisarius became a beggar means little to us when it seems only the difference between a rich and a tattered loga. We do not picture Belisarius in a patched pair of trousers: but then we have no reason to be angry with Belisarius. But whenever real tyranny and honest wrath are reborn among men, there will always be an instant necessity to represent the great reversal in the graphic colours of contemporary fact. Raemaekers' cartoon, representing the tyrants of Europe reduced to that very hopeless modern beggary to which they have driven many thousands of very much better men, is perhaps of all his pictures the most grim, or what would be called vindictive. I think that such revenge is in truth merely realization. The victims of the war have to sit on such real benches in such real rags. And being one of the fiercest, it is also one of the most delicate of the Dutch artist's studies. Nothing could be truer than the insolent and swollen decay of the Jew Ferdinant; or the more effeminate collapse of the Kaiser, the very spike on whose helmet droops with sentiment.
\end{abstract}

G. K. CHESTERTON. 


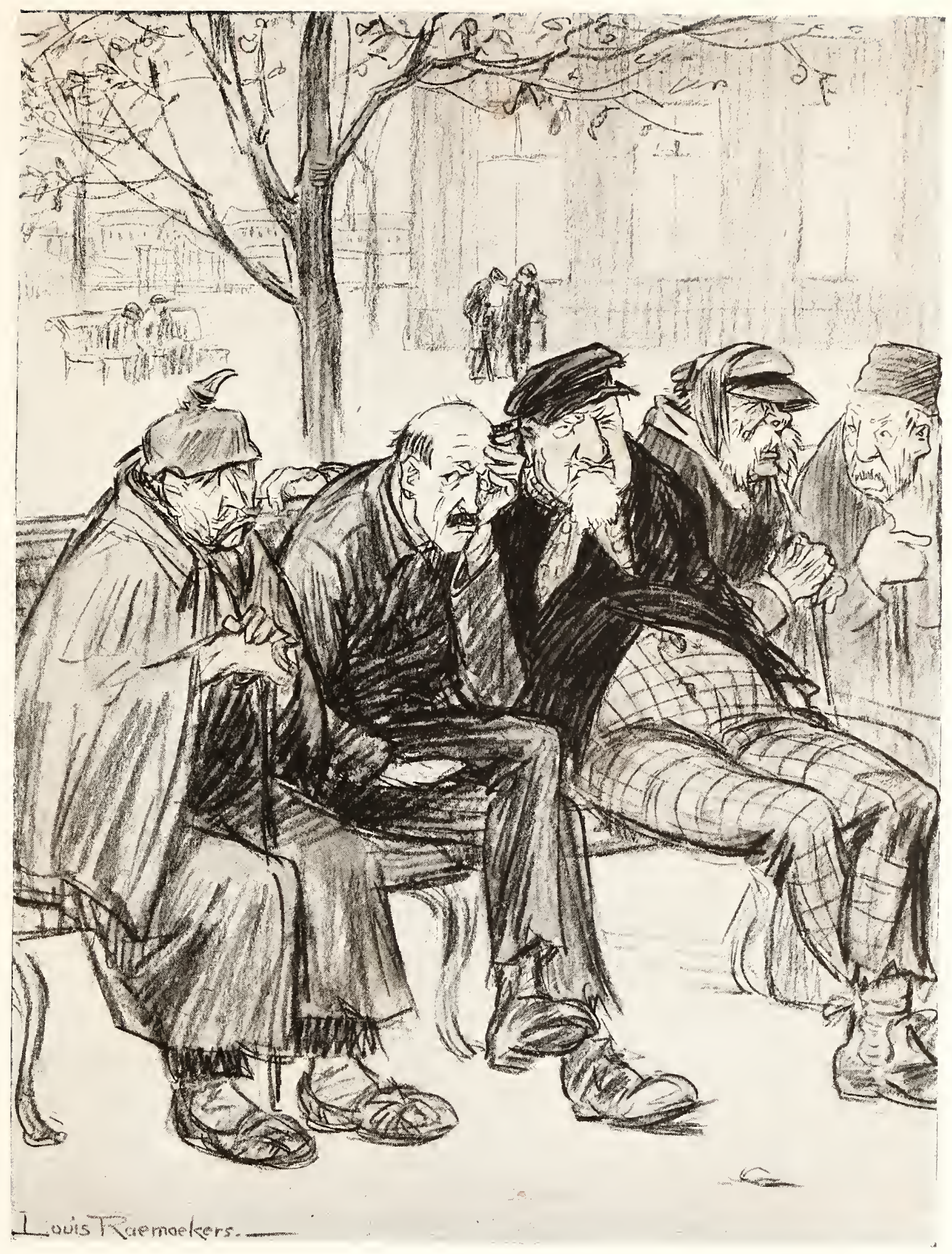

FIVE ON A BENCH

In a year and a half. 


\section{What About Peace, Lads?}

W

$\mathrm{AR}$ - so certain of their own prophets have said-is a "national industry of Germany." Here we see a German chevalier d'industrie attempting to escape with his swag. Never in modern times has a nation gone to war with a more cynical and shameless determination to make the campaign pay for itself by the plunder of private property. Quite recently an order was found on the body of a German, enjoining all officers to assist in the "patriotic duty" of "draining financially the occupied territories." We are dealing, not with an honourable and civilized nation, but with a band of murdering brigands. The keepers of the national conscience have devised a monstrous and barbarous code of ethics, in which "patriotism" is the sole duty, and the tribal god the only arbiter of right and wrong. As in Roman law, the property of an enemy is for a German res nullius - it has no owner. And now the prospect of any further loot on a large scale seems remote. The speculation has turned out badly, and the robber would be glad to cut his losses. The guardians of the law are at his heels, and do not mean to let him escape. But will they be able to make him disgorge? That will not be easy; and what atonement can be made for the innocent blood which drops from those pitiful spoils?

W. R. INGE. 


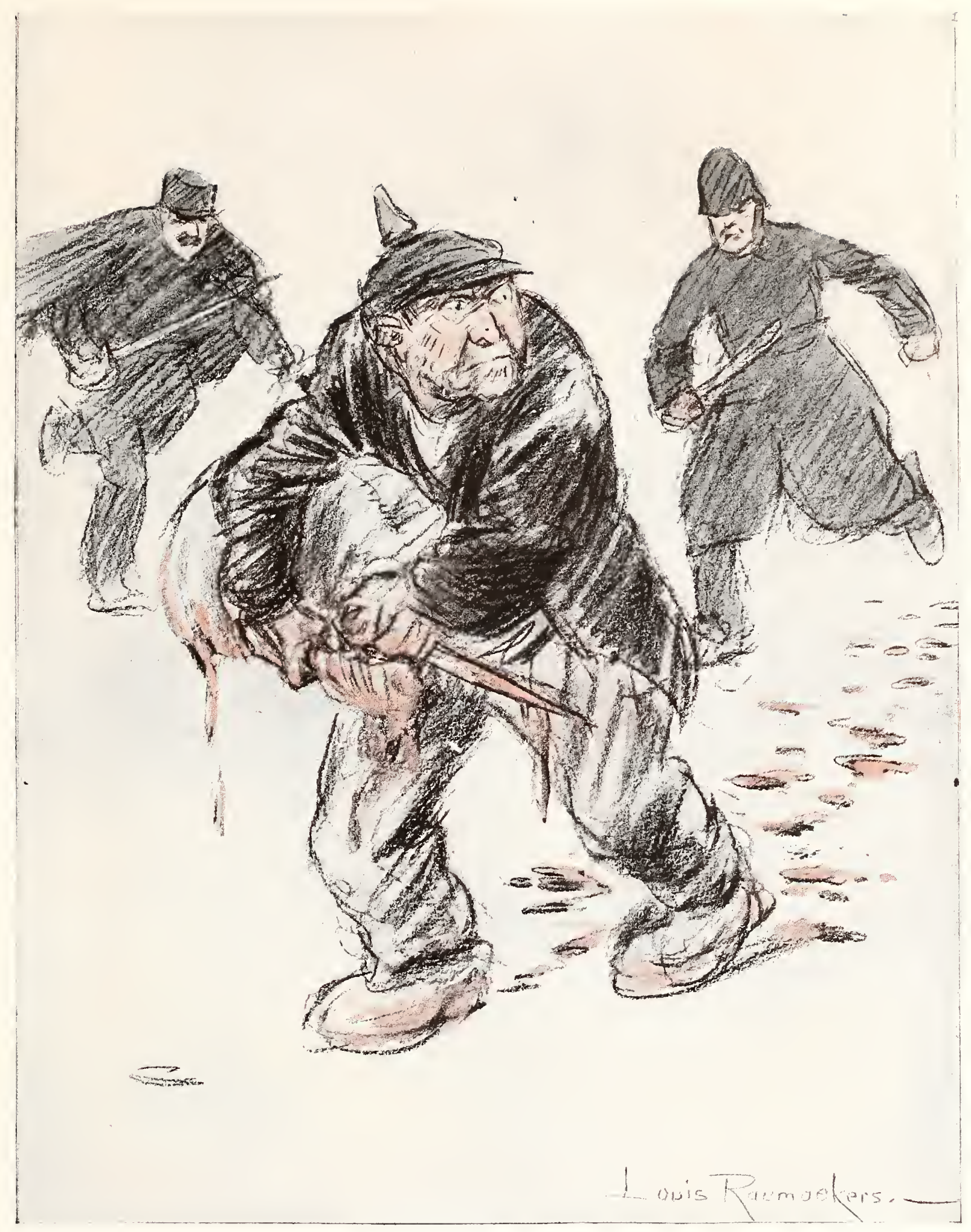

WHAT ABOUT PEACE, LADS? 


\section{The Liberators}

$\mathrm{T}$ HIS is one of those cartoons in which the neutral in Raemaekers speaks with peculiar force. Such a picture by a Britisher would reasonably be discounted as unduly prejudiced, for it is none too easy for us in our present stresses to see the other fellow's point of view - in this difficult business of the blockade for an instance.

That friendly championing of the rights of neutrals suffering under the outrageous tyranny of the British Navy is a thing to which only the detached humour of a neutral can do justice. He can testify to the way in which the giant strength of that navy, whether in peace or war, has been used in the main not in the giants' tyrannous way; he can make allowance for the exigencies which have caused occasional arbitrariness under the stress of war or even in some untactful moment of peace; he can contrast the two main opposing navy's notions of justice, courtesy, seamanship-which is sportsmanship.

He can recall that no single right whether of combatant or neutral, of state or individual, guaranteed by international law, which the Germans have found it convenient or "necessary" to violate has been left unviolated; that there is no single method or practice of war condemmed by the common consent of civilization but has been employed by men who even have the candour to declare that they stand above laws and guarantees.

And therefore he can make grim, effective fun of the sinister bandit with his foot planted on the shackled prisoner that lies between two murdered victims fatuously taking in vain the name of freedom.

JOSEPH THORP. 


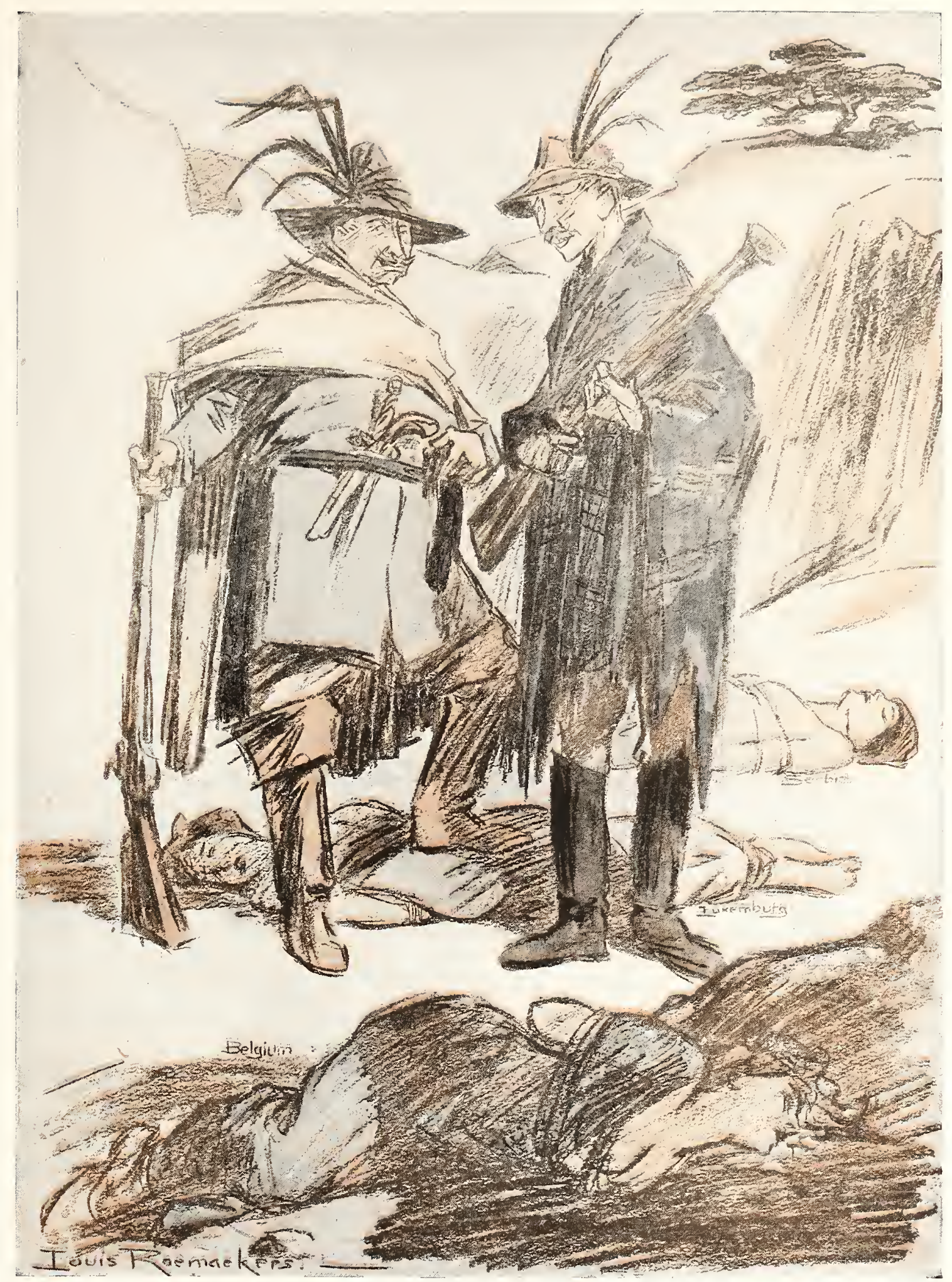

"Freedom of the land is ours-why should we not have freedom of the sea?" 


\section{Tom Thumb and the Giant}

$\mathrm{T}$

HE reference in this cartoon is to an incident which, at the time of its occurrence, is said to have caused considerable indignation in Germany. A Zeppelin, having been on a raiding expedition to England, was hit on the return journey, and dropped into the North Sea. The crew, clinging to the damaged airship, besought the captain of a British trawler to take them off, but the captain, seeing that the Zeppelin crew far outnumbered his own, declined to trust them, and left them to their fate. Whether the trawler's captain actually "put his thumb unto his nose and spread his fingers out" is a matter for conjecture, but under the circumstances it is scarcely likely.

The whole point lies in the German view of the trawler's captain and his inhuman conduct. He knew, perfectly well, that if he rescued the crew of the Zeppelin, the probable reward for himself and crew would be a voyage to the nearest German port and interment in a prison camp for the remainder of the war-and plenty of reliable evidence is forthcoming as to the treatment meted out to men in German prison camps. He knew, also, that these men who besought his aid were returning from one of the expeditions which have killed more women and children in England than able-bodied men, that they had been sharing in work which could not be described as even of indirect military value, but was more of the nature of sheer murder. And Germany condemned his conduct by every adjective that implied brutality and barbarity.

The unfortunate thing about the German viewpoint is that it takes into consideration only such points as favour Germany, a fact of which this incident affords striking evidence.

E. CHARLES VIVIAN. 


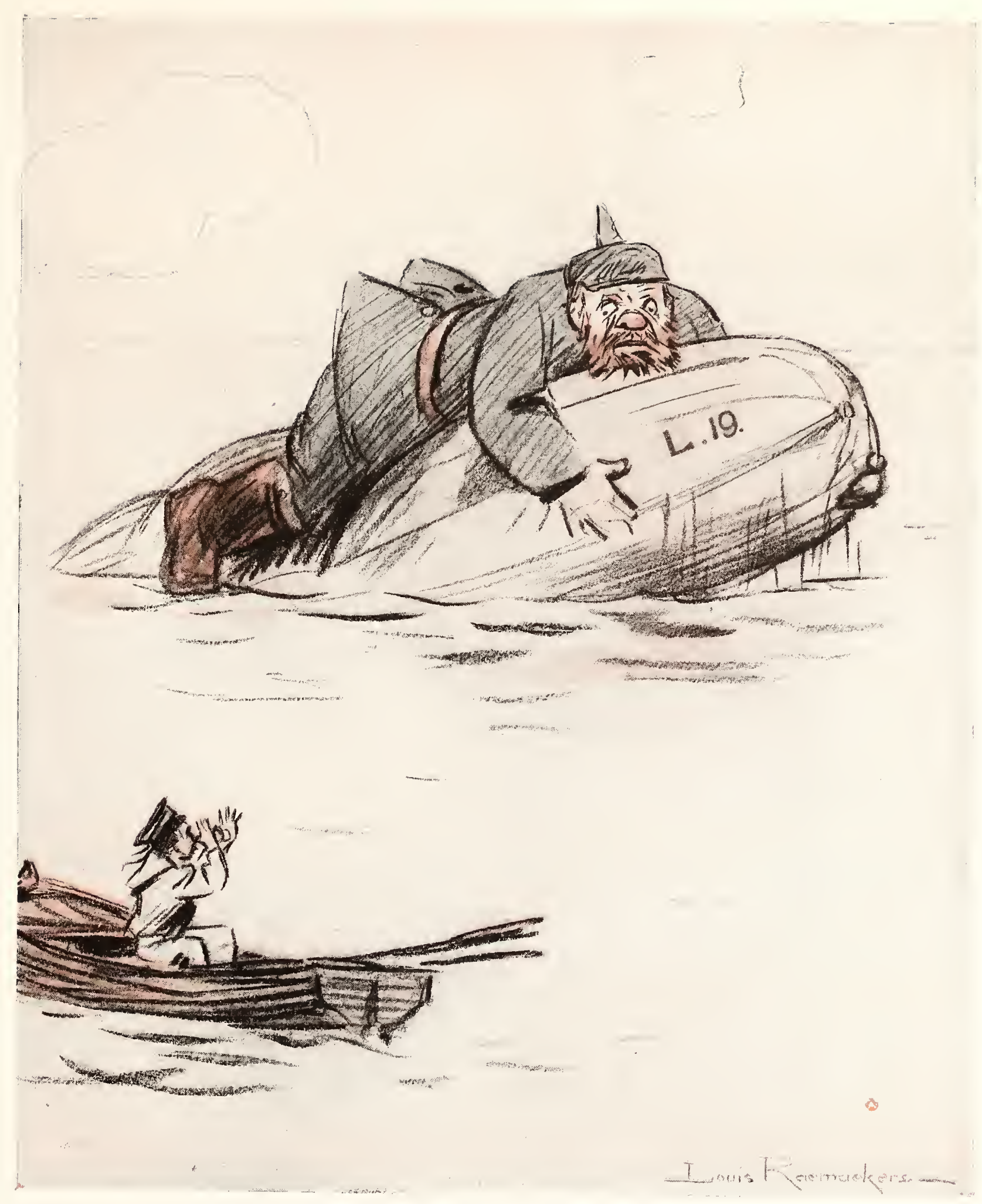

TOM THUMB AND THE GIANT

"Come and save me. You know I am so fond of children." 


\section{"We Have Finished Off the Russians"}

SSUMING that the statement with regard to finishing off the
Russians was actually written-and there is every reason to
assume it-one may conjecture what memories it recalled. The great battles of the Warsaw salient, the drive that lasted for many months through the flats of Poland, the struggles of the Vilna salient, and all the time the knowledge that mechanism, the guns in which Germany put her trust, were shattering Russian legions day after day. Then the gradual settling of the eastern line, well into Russia, with all the industrial districts of Poland firmly gripped in German hands, and the certainty that though Russia had not been utterly broken and forced to a peace, yet so much had been accomplished that there was no longer any eastern menace, but both Germany and Austria might go about their business of conquest in the west, having "finished off" in the east.

But that strong figure with the pistol pointed at the writer, that implacable, threatening giant, is a true type of Russia the unconquerable. It is a sign that the guns in which Germany put her trust have failed her, that the line which was to hold firm during the business of conquest in the west has broken-more, it is a sign of the doom of the aggressor. The writing of that fat, complacent figure-sorry imitator of the world's great conquerors-is arrested, and in place of stolid self-conceit there shows fear.

Well-grounded fear. History can show no crimes to equal the rape of Belgium and the desolation of Poland at the hands of Germany. The giant with the pistol stands not only as a returned warrior, but also as an avenger of unspeakable crimes.

E. CHARLES VIVIAN. 


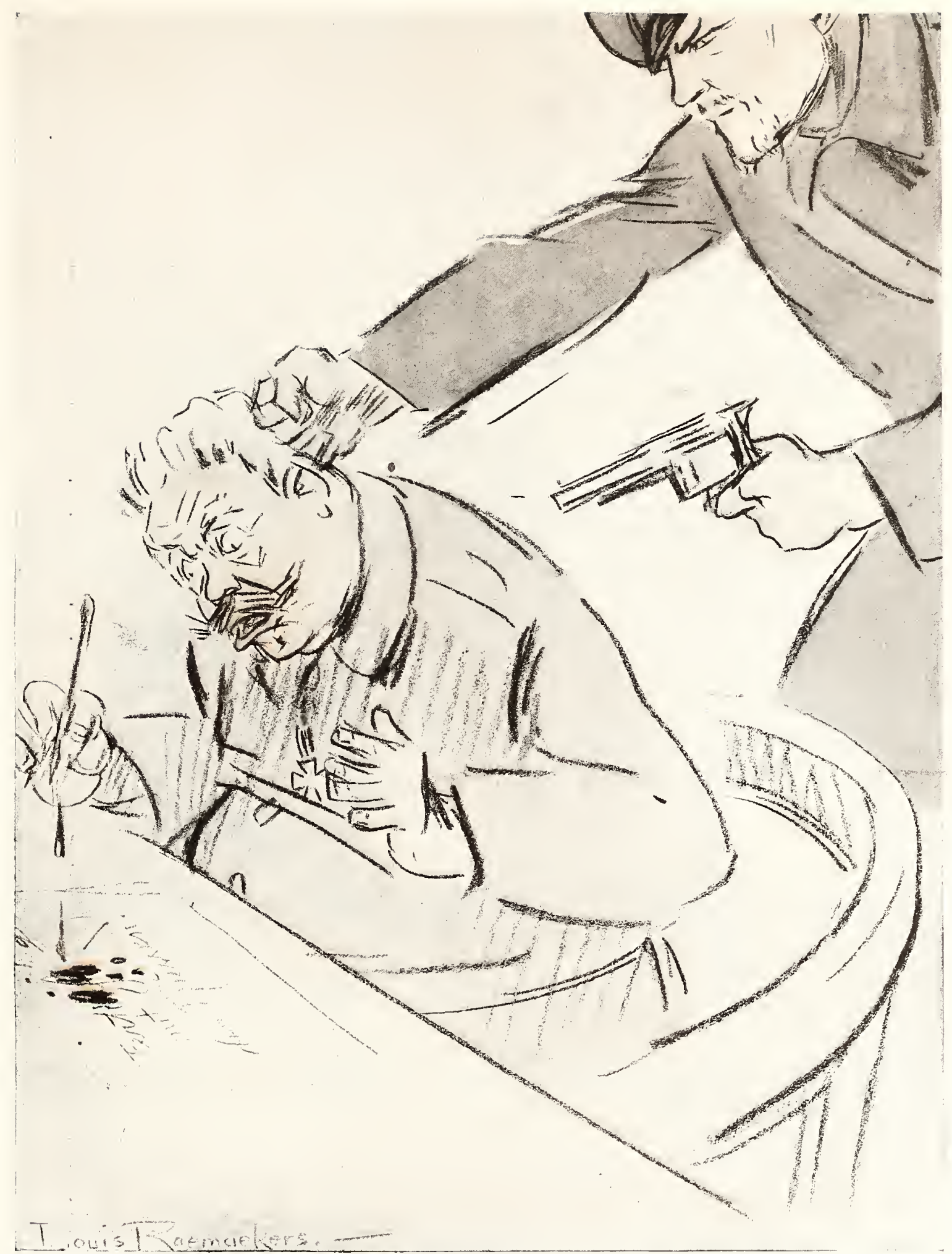

WE HAVE FINISHED OFF THE RUSSIANS. "Wait a moment." 


\section{Muddle Through}

LTHOUGH this striking cartoon of Raemaekers may, since the consummation of Lord Derby's Scheme and the raising of the new armies, be said to have lost its sting it cannot be said no longer to have a lesson.

At the time of its first publication the sight of England assailed by the central Empires bent on her destruction for having thrown the weight of her trident and her sword into the scales on the side of Justice and Right against Lawlessness and Might, failed to evoke in many of her sons the spirit of patriotism which has since manifested itself in many glorious and immortal deeds.

It was difficult for us to realize that we were at war. And at war not merely to protect the weak and uphold ideals of national righteousness, but for national existence itself. The doctrine of "muddle through" was not confined to the War Office and other Government Departments, but seemed to permeate the whole nation to a lamentable extent. In the cartoon we have three typical men with that fatal "business (or pleasure) as usual" expression on their faces. That Germany should seek to wrest the trident and sovereignty of the seas from the hand of Britain, or should have devastated Belgium and the North Eastern Department of France was obviously no personal concern of theirs. Let the other chaps fight if they would.

Happily for England and for her gallant Allies the point of the cartoon has been blunted, if not entirely destroyed, by subsequent events. But the lesson? It is not far to seek. Is it not that had "business as usual" not been so gladly adopted as the national creed in the early days of war, we might have been happy in the blessings of Peace by now, or at least have had Peace much nearer.

We do not envy the men who might have gone but who stayed at home in those early days, when their earlier presence on the field of battle might have been the means not only of saving many thousands of valuable lives, but of shortening the terrible carnage. It would have been a thousand times better had the mind which conceived the phrase "business as usual" been acute enough to foresee the possible and disastrous misapplications of the phrase. Rather would it have been better had the idea crystallized in "Do it now."

CLIVE HOLLAND. 


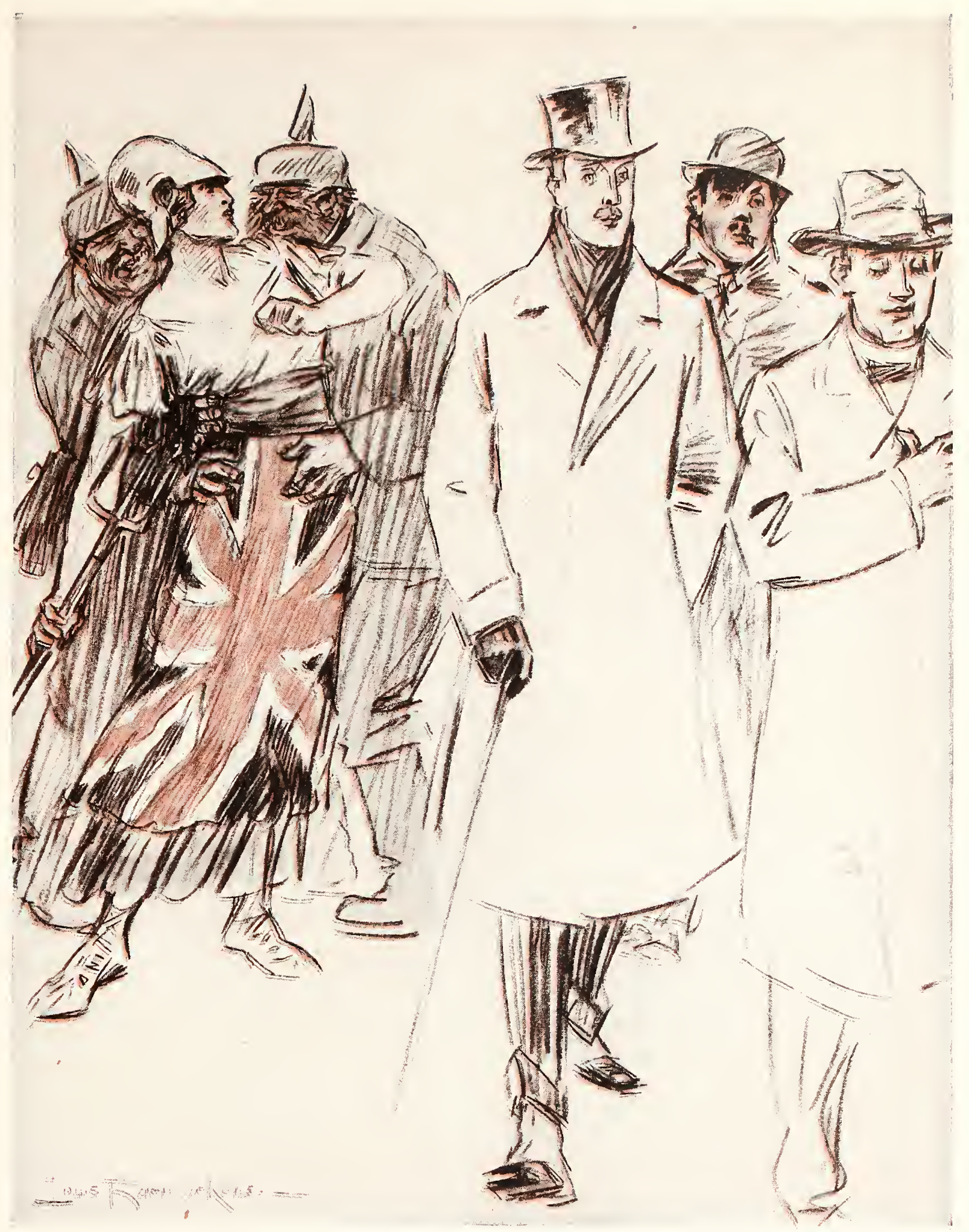

MUDDLE THROUGH 


\section{My Enemy Is My Best Friend}

$\mathrm{T}$ HESE words of Emerson's express exactly the thought of this cartoon. The Netherlands is a country that has been slowly won from the ocean; the cruel sea has always been its enemy, at first completely triumphant, then gradually resisted and driven forth by the enterprise and toil of men; but it is always an enemy to be dreaded. Its inroads have to be guarded against by great dykes and by the never-ceasing care and industry of the nation. Now and again the floods come, and people barely escape in boats from the waters. Yet time and again the enemy has been the best friend of the Netherlands. This enemy has saved them from the domination of Spain, and now, as the refugees on the floods of last winter are escaping from the jaws of death they feel that the water which is now an enemy (vijand), may to-morrow be a friend (vriend); for an invasion by the Germans, that ever-dreaded danger to all patriotic Dutchmen, can be guarded against only by the friendly help of the ocean which can be invoked in case of need to save its own people. It was only in the last resort that William the Silent consented to let in the sea. He resisted the Spaniards as long as he could, and only when all possible chance of further resistance was at an end did he have recourse to the sea as the last friend. He saved the country by allowing the German Ocean to destroy it. In this cartoon the people in the boats regard the sea as their enemy; but an invasion by German armies could not be resisted except with the help of the friendly sea, whose voice is the voice of Freedom.

WILLIAM MITCHELL RAMSAY. 


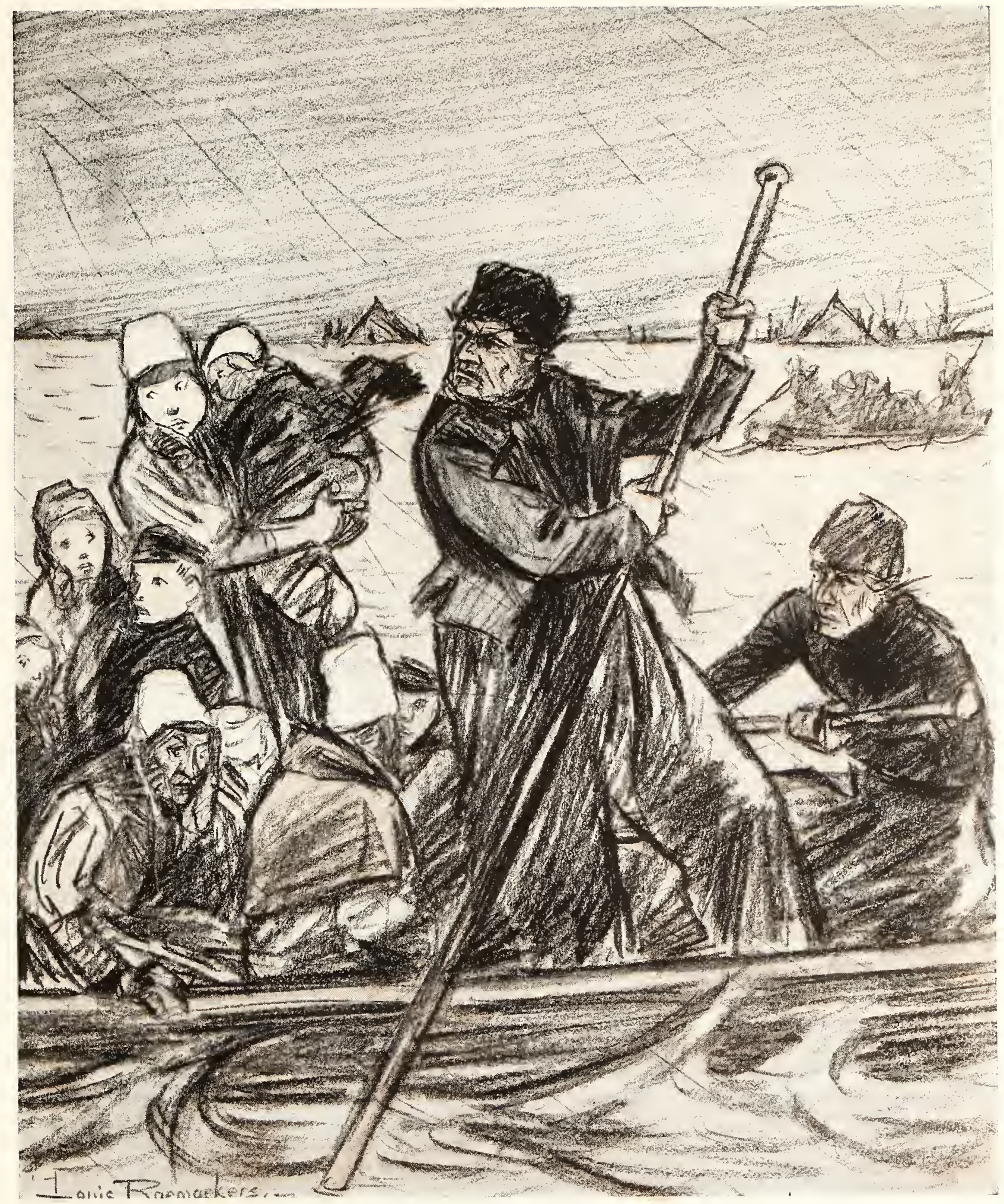

The Floods in Holland-now a fiend, to-morrow a friend. 


\section{How I Deal With the Small Fry}

$\mathrm{P}$

ERHAPS only those who have the opportunity of reading the papers pubiished in neutral countries, and have made a study of the mendacious "news for neutrals" issued by the notorious Woolf Agency and German Wireless Bureau, are able to grasp the powerful inner motive which actuates Raemaekers in the persistence with which he seeks to drive home the tragic stories of Belgium and Luxemburg. At this time of day it might seem superfluous to issue a cartoon of this kind. But is it? With neutral opinion apparently by no means convinced as yet of the sinister designs of Prussianism upon the liberties of Europe and especially of smaller nations a drawing of such poignancy and force cannot fail to arrest the attention and bring home the lesson of that creed which has for its gospel such phrases as "Necessity knows no law" and "Force shall rule." It is inconceivable to the thinking mind that there can be a man or woman who, with the story of the violation of Belgium and Luxemburg before them, can possibly hesitate to brand the German nation with the mark of Cain, and tremble at the mere possibility that might should triumph over right.

Our wonderment is all the greater when we remember how the Kaiser and his murderous hordes have made no secret of their methods. They may in the end seek to deny them, to repudiate the deeds of blood and of unholy sacrilege and violence which in the early days of war were avowed concomitants of their policy, but such disavowal is not yet.

Beneath the Kaiser's heel in bloody reality lie at the present time Belgium and unprotected Luxemburg every whit as much as is shown by the powerful pencil of the artist.

The reign of lust, cruelty, and destruction is not yet done, though the signs and portents of the end are not now a-wanting. The blood of men, women, and little children shall not cease to cry aloud for vengeance until the Prussian eagle is humbled in the dust, and its power for evil is utterly destroyed. This is a good cartoon to bear in mind and look upon should "War weariness" ever overtake one. It will be a good one to have upon one's wall when peace talk is head in the land.

Thomas Moore may be said to have composed an epitaph for Prussianism three-quarters of a century ago when he wrote the lines:

"Accursed is the march of that glory

Which treads o'er the hearts of the free."

A great statesman has declared "the Allies will not sheathe the sword until Justice is vindicated." Let us add "and until reparation is exacted to the uttermost farthing from these responsible for this bloody conflict and its diabolical crimes, whether the perpetrators be high or low."

CLIVE HOLLAND. 


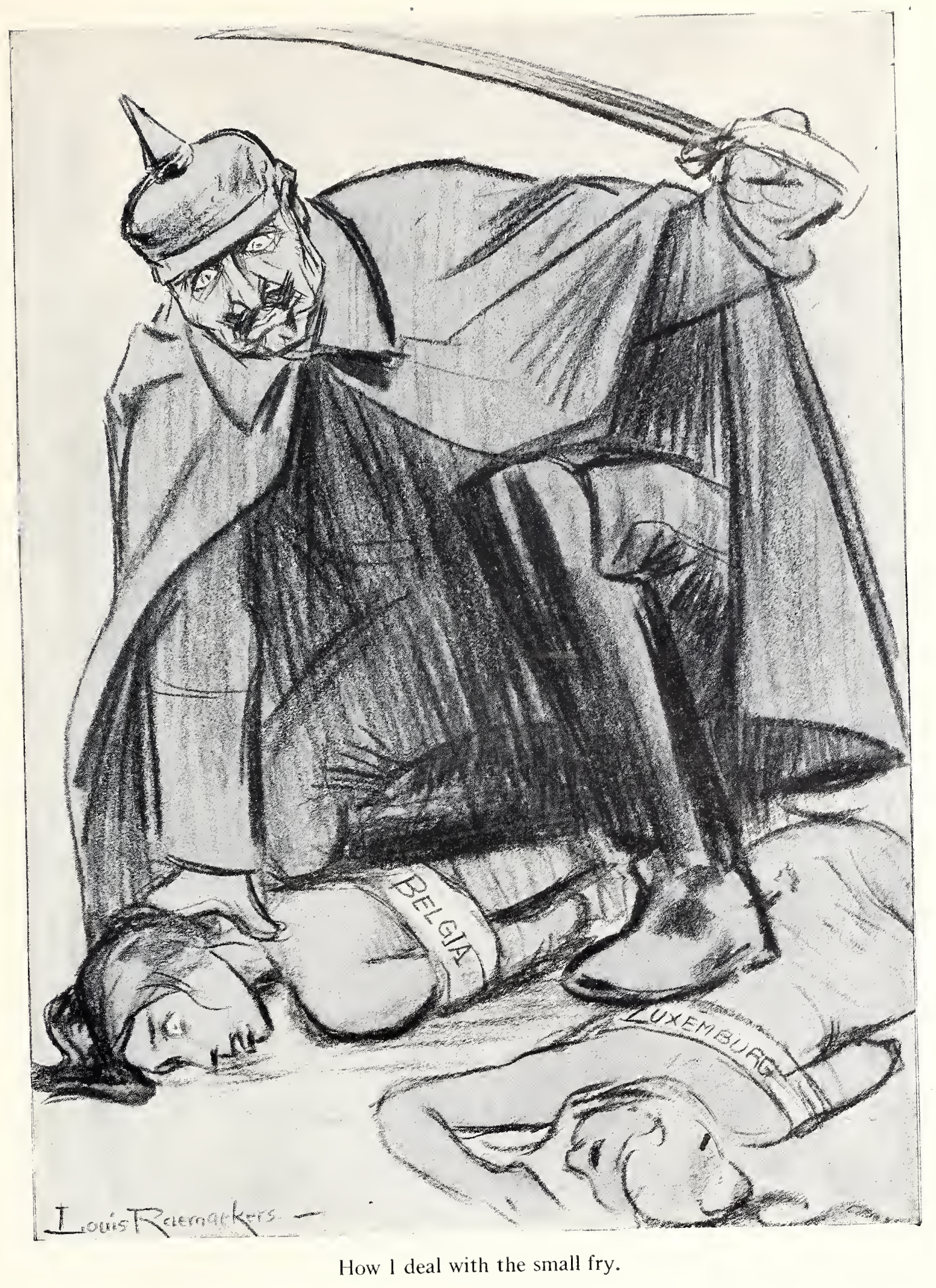




\title{
The Two Eagles
}

\begin{abstract}
1 DOUBLE-EDGED satire on both political birds. Neither is"a true eagle. They have talons but nothing of the noble air proper to the ling of birds. The German bird is not an eagle but a vulture; and he is in a sorry plight, with torn and ruffled feathers, dishevelled, dripping blood. He is disappointed, angry, soured, and unhappy. Yet he is straightforward about it. He makes no attempt to disguise his feelings, but glares at the other with the indignation of one who has been deceived written on his face and vibrating in his voice.
\end{abstract}

And his reproach gets home. The American bird, who is bigger and stands on a bigger rock, is sleek enough except about the head which is a bit ruffled. But he is more of a raven than an eagle in his sable plumes of professional cut, and he is obviously not at ease. He does not look the other in the face. He stares straight in front of him at nothing with a forced, hard and fixed smile, obviously assumed because he has no reply to make.

During the war many indiscreet phrases have dropped from the lips of prominent persons who must bitterly regret them and wish them buried deep in oblivion. But they stand on record, and history will not let them die. "Too proud to fight" is the most unfortunate of all, and when others are forgotten it will remain, because it has a general application. Mr. Racmaekers exposes its foolishness here with a single masterly touch and he puts the exposure in the right mouth. The cartoon is an illuminating epitome of the interminable exchange of notes between the two Powers on submarine warfare.

A. SHADWELL. 


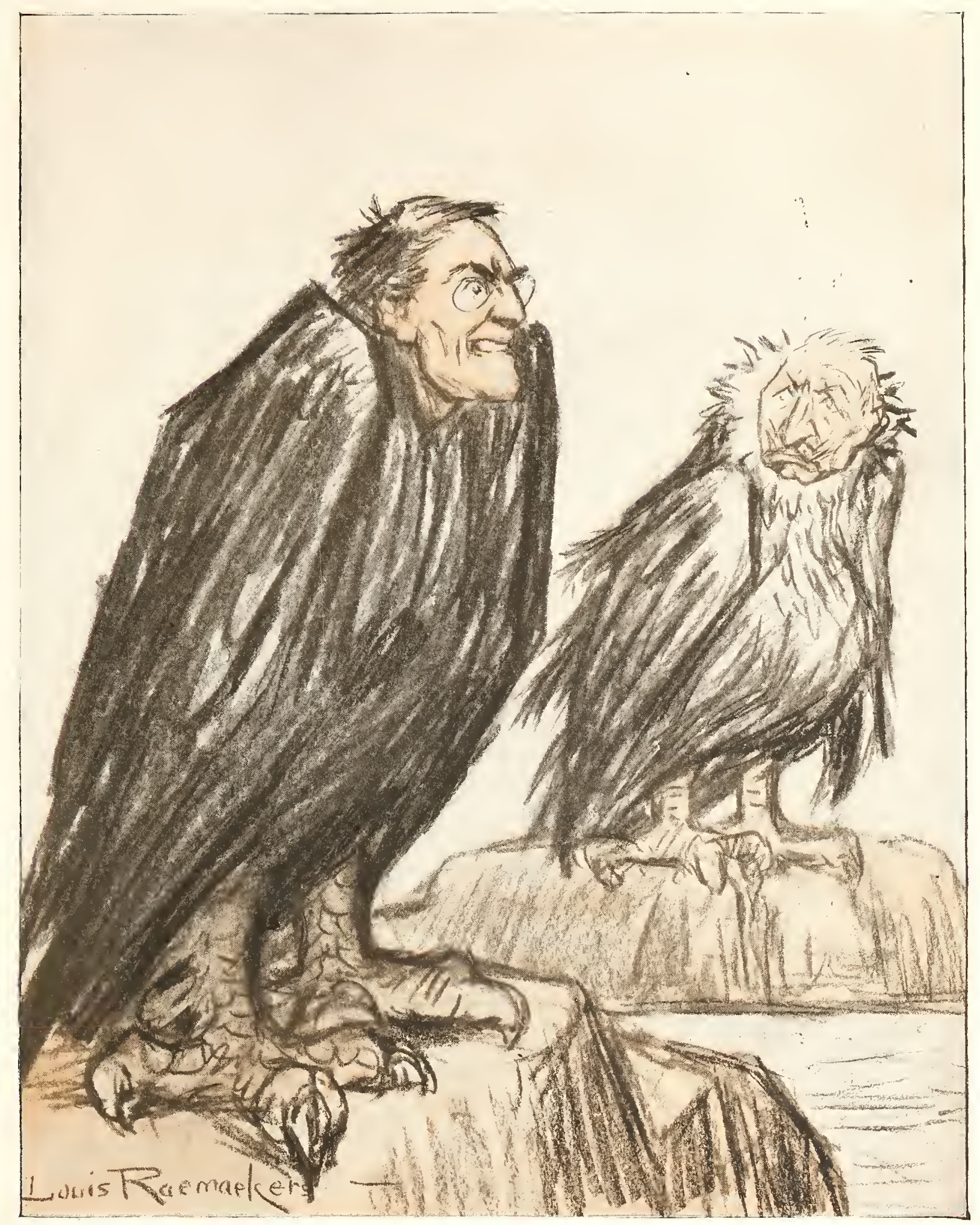

"I thought you said you were too proud to fight.' 


\section{London-Inside the Savoy}

$\AA^{\mathrm{T}} \mathrm{A}$ first glance this cartoon would seem to imply that the people inside the Savoy had little interest in the war, for the figures in evening dress are well in the foreground; a count of heads, however, will show six, and possibly seven men in uniform and only four in civilian attire, and of the soldiers not one is dancing-they are lookers-on at these strange beings who pursue the ordinary ways of life.

Of such beings, not many are left-certainly not this proportion of four to six, or four to seven. Compulsion has thinned the ranks of the shirkers down to an irreducible minimum, and a visit to the Savoy at any time in the last six months of 1916 would show khaki entirely preponderant, just as it is in the streets. These correctly dressed and monocled young men have been put into the national machine, and moulded into fighting material-their graves are thick in Flanders and along the heights north of the Somme, and they have proved themselves equal and superior to what had long been regarded as the finest fighting forces of Europe.

It is in reality no far cry from the Somme fighting area to the light and the music of the Savoy, and a man may dance one night and die under a German bullet the next - many have already done so. Here the artist shows the lighter side of British life to-day, but one has only to turn to the companion cartoon to this, "Outside the Savoy," to see that he realizes London as thoroughly in earnest about the war.

E. CHARLES VIVIAN. 


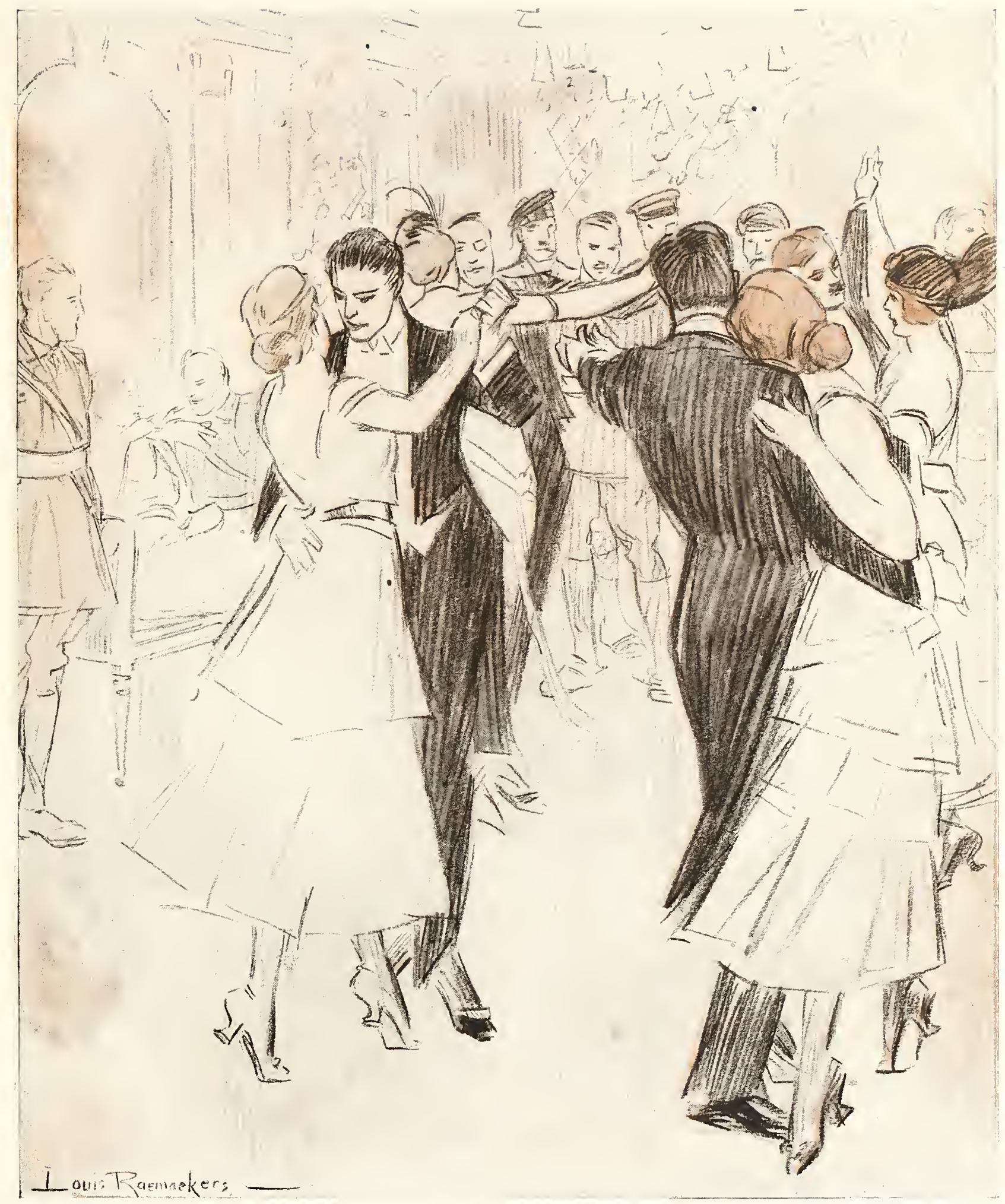

LONDON-INSIDE THE SAVOY 


\section{London-Outside the Savoy}

$\mathrm{T}$

HE newsboy, under military age; one man, well over military age; three women-and all the rest in uniform-even the top of the bus that shows in the distance is filled with soldiers. Thus Raemaekers sees the Strand, one of the principal thoroughfares of the heart of the British Empire.

For the sake of contrast with the companion cartoon, "Inside the Savoy," there is a slight exaggeration in this view of London street life in war-time - the proportion of civilians to soldiers is necessarily greater than this, or the national life could not go on. A host of industries are necessary to the prosecution of the war, and it falls to some men to stay behind-many of them unwillingly.

There was a time, in the early days, when Britain suffered from an under-estimate of the magnitude of this task of war-a time which the cartoon "Inside the Savoy" typifies in its presentment of careless enjoyment. But that attitude was soon dispelled, and it is significant of the spirit of the nation that only when nine-tenths of the necessary army had been raised by voluntary-indeed, this is a certainty, for not until long after the cartoon was published did any conscripts appear in the streets. Though, in the proportion of soldiers to civilians, the cartoon may exaggerate, in its presentment of the spirit of the nation, and of the determination of the nation with regard to the war, it is true to life.

E. CHARLES VIVIAN. 


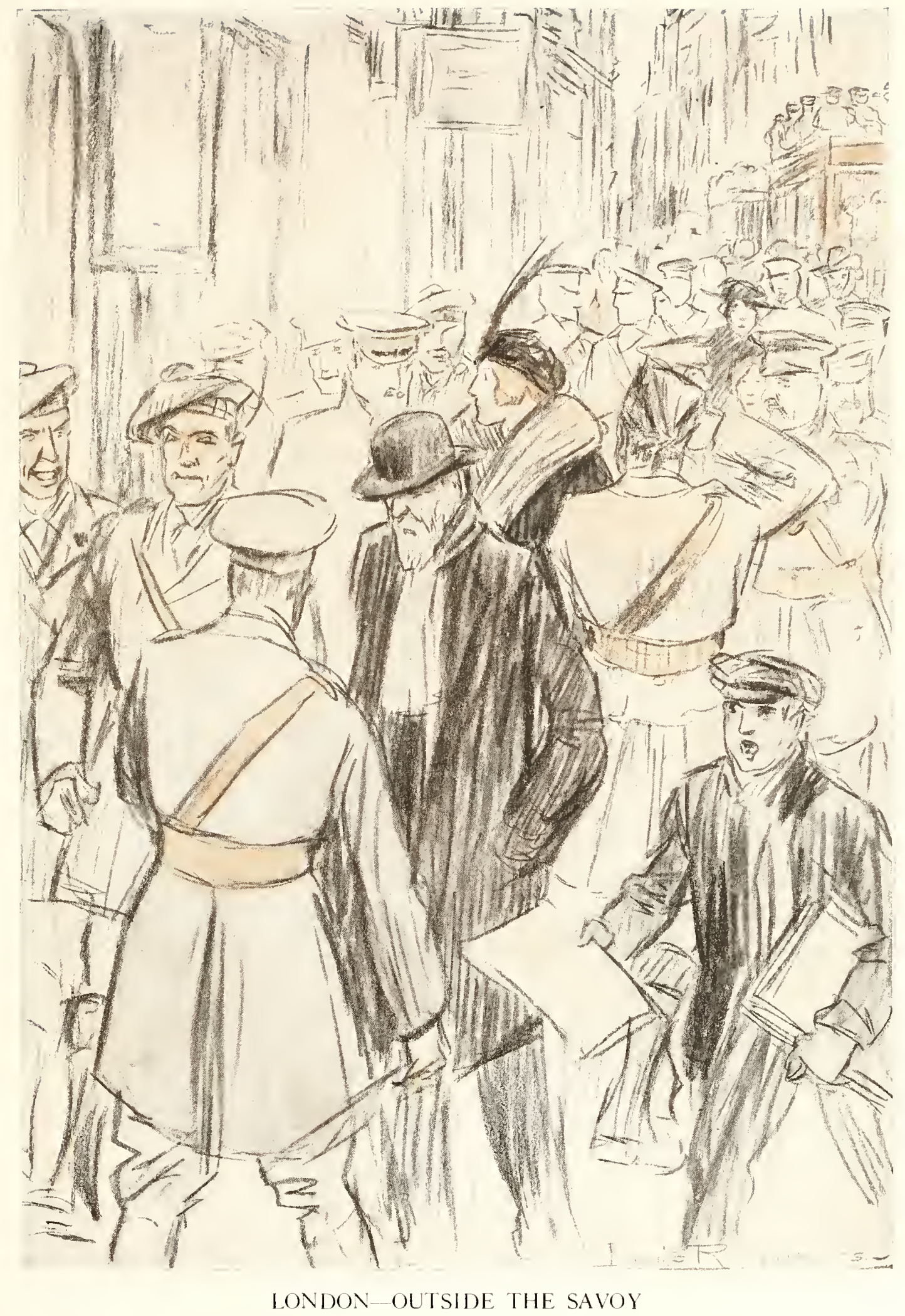




\section{The Invocation}

T

HIS drawing touches the highest level of the draughtsman's art and demonstrates the unique power of the pencil in a master hand. So simple, so true, so complete, so direct and so eloquent is the message that words can add nothing to it. They can only pay a tribute of appreciation.

Everybody can read the meaning at a glance; none can read it wholly unmoved. For here is pure humanity, which none can escape, the primal instinct without which man that is born of woman would not be. Before this weak, bowed, and homely figure Knowledge is silent, Pride and Passion are rebuked. Strength is shamed. Motherhood and mother-love transcend them all.

There is here nothing of anger, no thought of hostility or revenge, no trace of evil passion. Only a mother yearning after her son and pleading to another mother, the Divine type of motherhood, the Mother of God. And what she asks is so little, only to see him again. She has given him, as the mother to whom she prays gave her Son, and she does not demand him back. She reproaches no one, accuses no one, makes no complaint and no claim for herself, but meekly pleads that she may be allowed to see him again to still the longing in her breast. She is a woman of the people, a simple peasant, but she personifies all mothers in every war, as she bows her silvered head in humble prayer at the way-side shrine.

A. SHADWELL. 


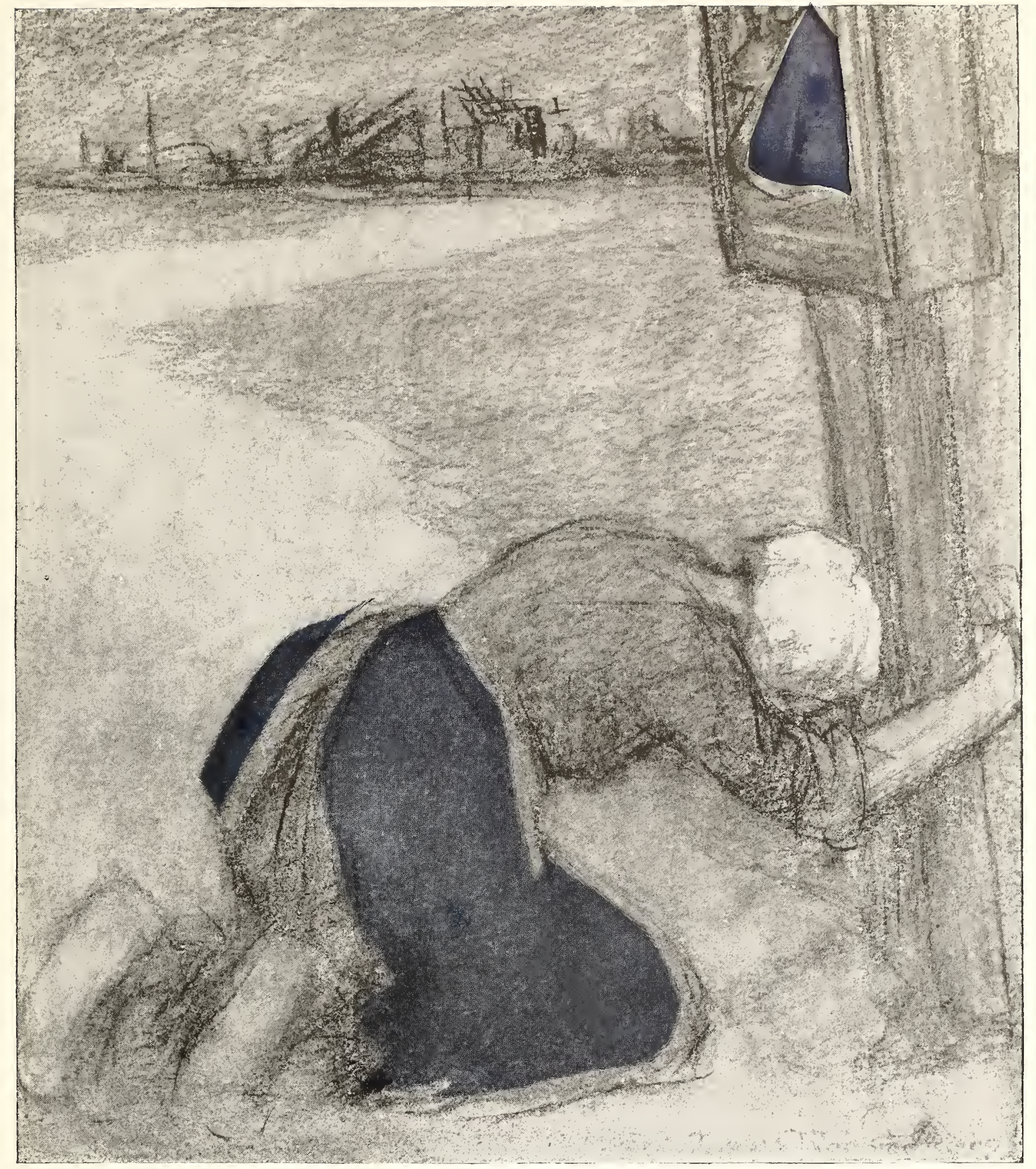

MON FILS - BELGIUM, 1914

"Let me see him again, Holy Virgin!" 
THE COUNTRY LIFE PRESS GARDEN CITY, N. Y. 



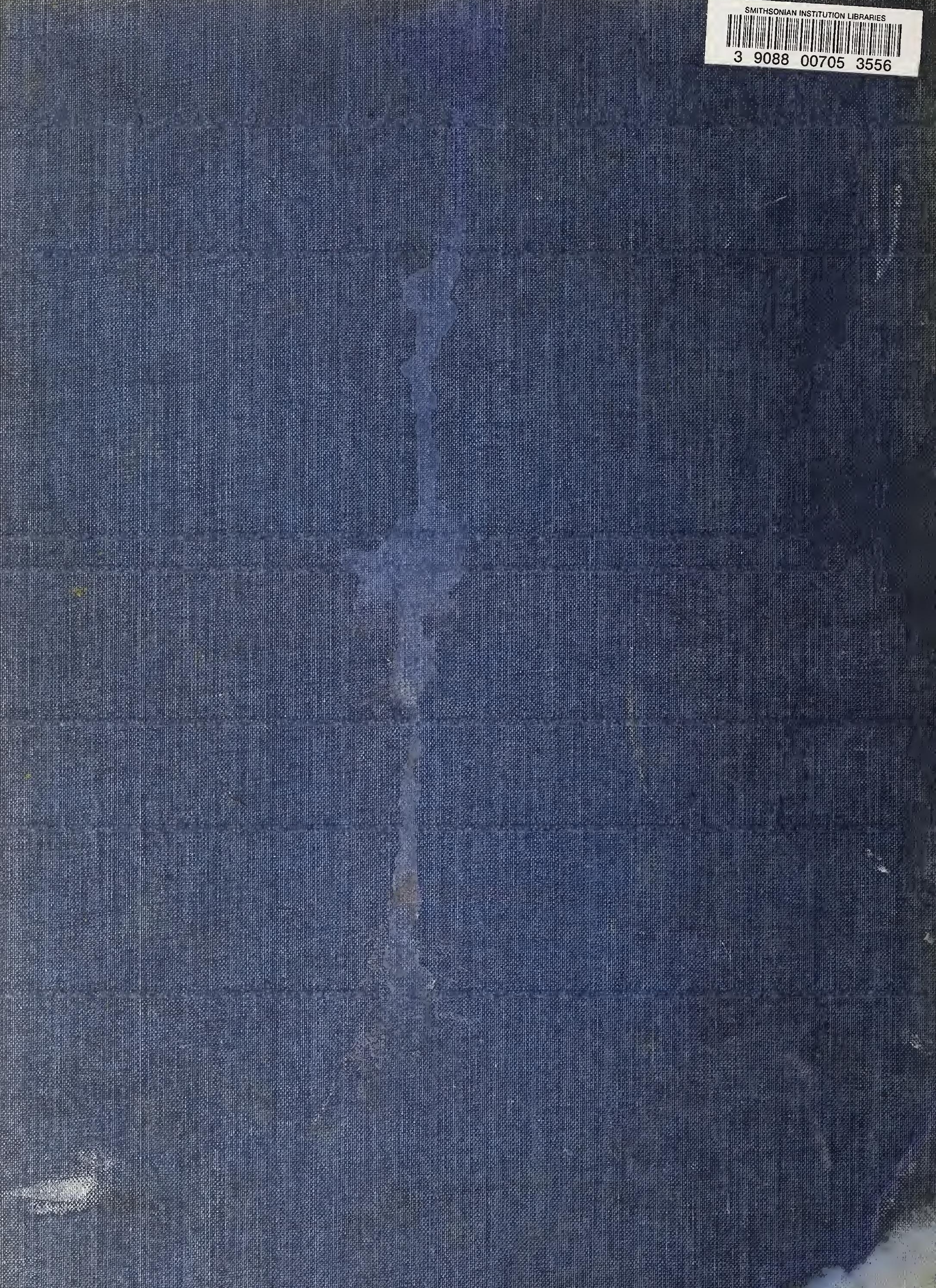